Sintia Otuka Rossi Maria do Carmo Monteiro Kobayashi (Organizadoras)

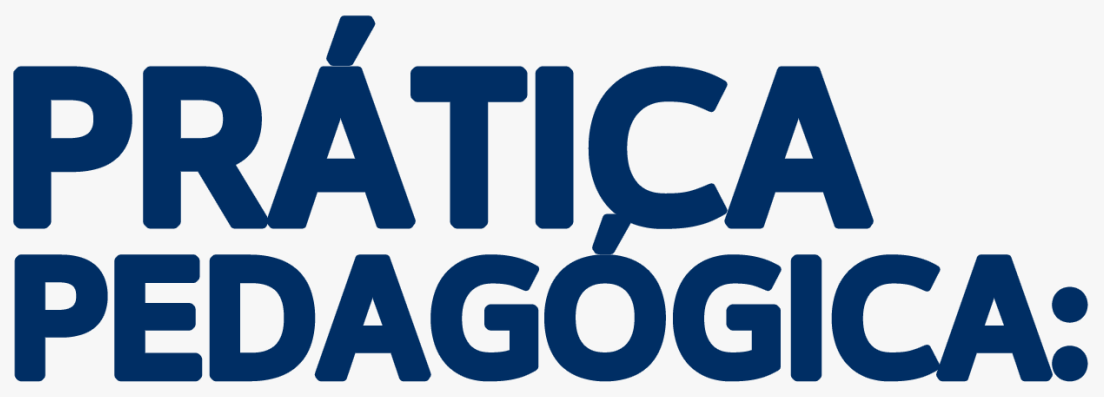

intencionalidade e sentido na Educação Infantil 



\title{
Prática Pedagógica: \\ Intencionalidade e Sentido \\ NA EdUCAÇÃo InfantIL
}

\author{
Sintia Otuka Rossi \\ Maria do Carmo Monteiro Kobayashi \\ (Organizadoras)
}




\section{(C) 2021 - Gradus Editora}

ROSSI, Sintia Otuka, KOBAYASHI, Maria do Carmo Monteiro (Orgs.). Prática Pedagógica: Intencionalidade e Sentido na Educação Infantil. 1ª Ed: Gradus Editora, 2021. Bauru, São Paulo.

ISBN: 978-65-88496-46-6

\section{Organizadoras}

Sintia Otuka Rossi

Maria do Carmo Monteiro Kobayashi

Ficha Técnica

Editor-chefe

Lucas Almeida Dias

Projeto Gráfico

Paulo Ricardo Cavalcante da Silva

\section{Diagramação}

Natália Huang Azevedo Hypólito

\section{Revisão}

Jancen Sérgio Lima de Oliveira 
Comitê Editorial Científico - Gradus Editora 2020/2021

Dra. Ana Beatriz Duarte Vieira

Dra. Ana Cláudia Bortolozzi

Dra. Andreia de Bem Machado

Dr. Carlos Gomes de Castro

Dra. Cintya de Oliveira Souza

Dra. Daniela Marques Saccaro

Dr. Douglas Manoel Antonio de Abreu Pestana dos Santos

Dr. Fábio Roger Vasconcelos

Dra. Gladys del Carmen Medina Morales

Dr. Gustavo Schmitt

Dra. Janaína Muniz Picolo

Dr. Leandro Antônio dos Santos

Dr. Luís Rafael Araújo Corrêa

Dra. Manuela Costa Melo

Dra. Márcia Lopes Reis

Dra. Renata Cristina Lopes Andrade

Dr. Thiago Henrique Omena

Dr. Yan Corrêa Rodrigues 
Dados Internacionais de Catalogação na Publicação (CIP)

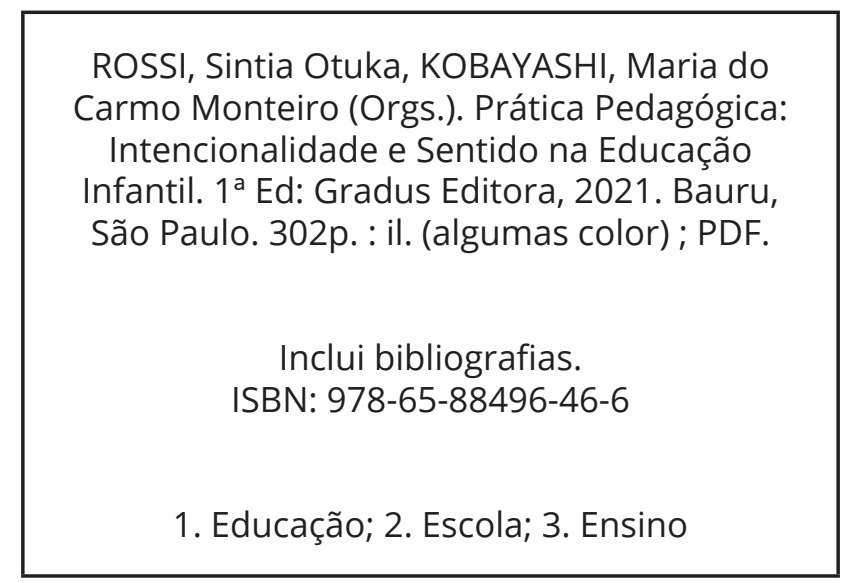

CDD 360.00 
SUMÁRIO

Prefácio

11

A Cultura Corporal Com Bebês E Crianças Bem

Pequenas:

Possibilidades De Ações Pedagógicas $\mathrm{Na}$

Educação Infantil

A Educação Infantil Fol Concluída... Como

Prosseguir?

A Continuidade Do Brincar E Aprender

47

A Relação Escola E Família Na Escolarização Das

Crianças Em Período De Pandemia:

Desafios Do Ensino Remoto

Arte LiterÁRIA:

Articulação Entre Ouvir, Falar, Ler E

Escrever Na Educação Infantil 95

Bioma Cerrado:

Um Conteúdo Para Além Das Ciências

Naturais Na Educação Infantil

Dança Na Educação Infantil, Um Movimento Possível

Encontro De Encantos:

Arte E Educação Infantil 165 
Intencionalidades Ao Proporcionar A Atividade PRINCIPAL DA INFÂNCIA:

O Brincar 183

LUGARES DA INFÂNCIA:

Os Ambientes De Aprendizagem Da

Criança Pequena Em Tempos De Pandemia Covid-19

205

O Processo De Representação E Simbolização Na

EdUCAÇÃo INFANTIL:

Contribuições Para O Desenvolvimento

Da Linguagem Escrita Na Perspectiva Da Pedagogia Histórico Crítica

Um Olhar Sobre A Flora Do Distrito De Tibiriçá:

Representando A Vegetação Por Meio Da Arte 253

Yoga Com Histórias Na Educação Infantil 271

Sobre Os Autores 295 


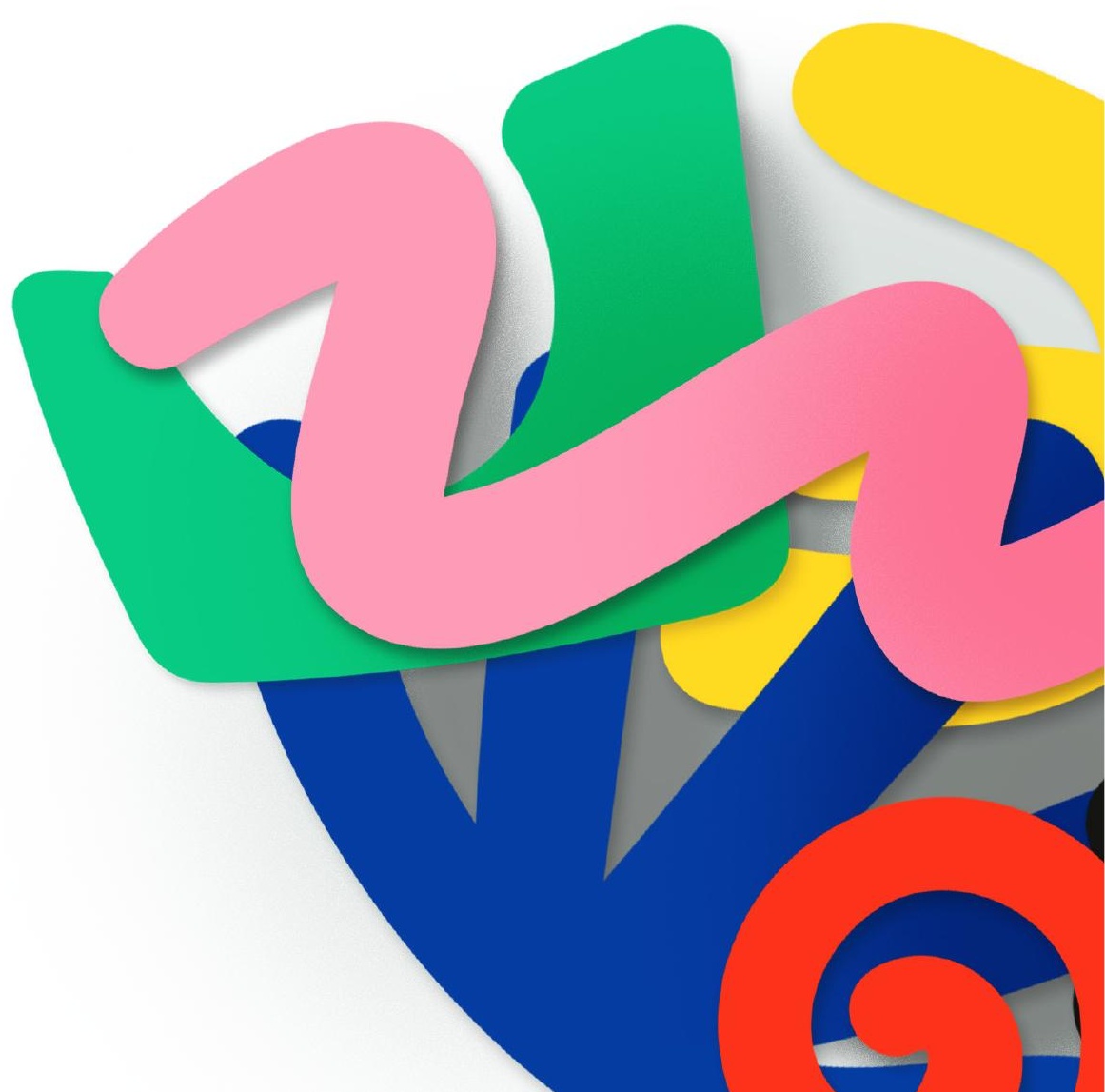




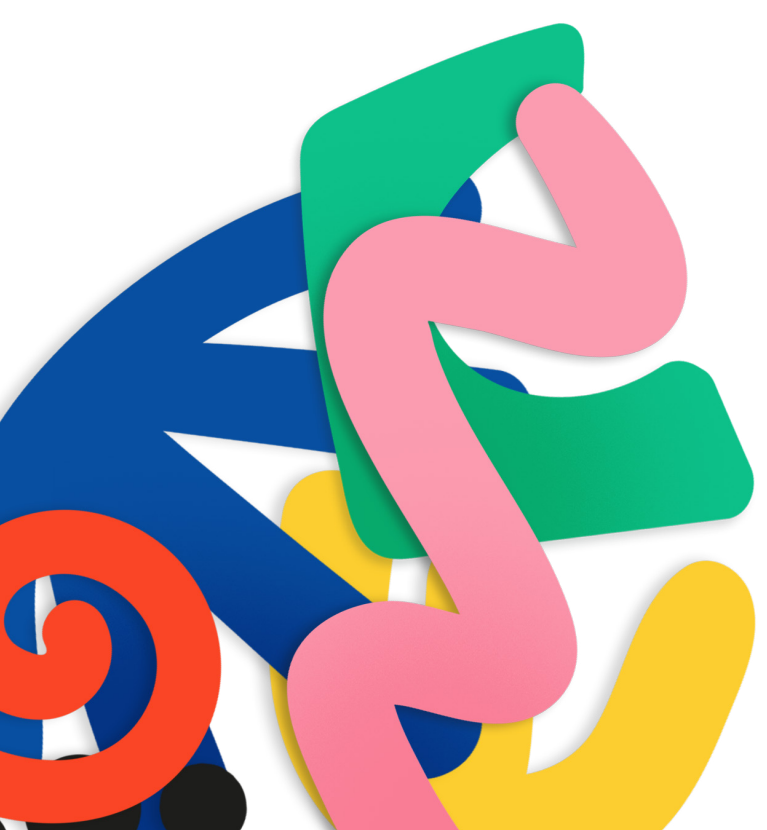




\section{PREFÁCIO}

Alice perguntou: Gato Cheshire... pode me dizer qual

o caminho que eu devo tomar? Isso depende muito do lugar para onde você quer ir disse o Gato.

Eu não sei para onde ir! - disse Alice. Se você não sabe para onde ir, qualquer caminho serve.

(Alice no País das Maravilhas) Lewis Carrol

Apresentamos esta obra a vocês, professores, gestores, pais, alunos de graduação e a todas as pessoas encantadas e interessadas pela valorização da infância e construção da escola de Educação Infantil como espaço de aprendizagem e desenvolvimento.

Neste livro compartilhamos práticas pedagógicas realizadas por professores com crianças pequenas de zero a cinco anos de idade. Não se trata de apresentar atividades prontas a serem copiadas e aplicadas aos pequenos, trata-se sim, de partilhar percursos e conhecimentos embasados em teorias e documentos normativos, a fim, de proporcionar reflexão e identidade do professor da Educação Infantil, como um intelectual empenhado com o fazer pedagógico consciente e comprometido com uma educação de qualidade.

A Lei de Diretrizes e Bases da Educação Nacional no 9394/96 (BRASIL, 1996) legitimou a Educação 
Infantil como primeira etapa da Educação Básica. A criança, sujeito social e histórico que brinca, narra, canta, imagina, constrói, questiona e procura atribuir significado ao mundo, tem direito a uma aprendizagem que faça sentido nesse período rico e único da vida.

A escola, por sua vez, deve propiciar o acesso ao saber elaborado sobre o cotidiano, todavia, de forma não cotidiana e sistematizada. Assim, esse novo contexto representa uma oportunidade de considerar a infância e potencializar um trabalho educativo planejado, intencional e baseado no conhecimento científico.

Os professores precisam organizar seu trabalho pedagógico fundamentado na ação-reflexão-ação 12 para atingir a atividade fim da educação: o ensino. Logo, esse objetivo é alcançado quando se tem clareza de onde se quer chegar, isso se dá por meio da escolha de experiências e vivências e as formas mais adequadas para promover o desenvolvimento integral da criança pequena.

Nessa direção, a presente produção aborda temáticas como a Arte e sua importância para a criança; as possibilidades de ações pedagógicas da Cultura Corporal com bebês, bem como a Dança e a Yoga como linguagens e movimento. O brincar, o faz-de-conta, os primeiros rabiscos e o desenho são vivências lúdicas necessárias à fase que antecede a alfabetização e estarão delineados nas próximas páginas deste livro. Investigações e descobertas 
sobre a fauna e o Cerrado proporcionam a riqueza do trabalho baseado na curiosidade e criatividade. Por fim, porém, não menos importante, os espaços de aprendizagem e o essencial trabalho colaborativo entre a escola e família em tempos de pandemia também são descritos aqui.

Assim, tais proposições objetivam promover a compreensão do trabalho planejado e intencional para a promoção da aprendizagem e desenvolvimento integral da criança pequena na Educação Infantil.

Sintia Otuka Rossi 



\section{A CULTURA CORPORAL COM BEBÊS E CRIANÇAS BEM PEQUENAS: POSSIBILIDADES DE AÇÕES PEDAGÓGICAS NA EDUCAÇÃO INFANTIL}

Ana Claudia da Silva Pereira

Fernanda Rossi

\section{INTRODUÇÃO}

Este capítulo teve como base e referência a pesquisa realizada no Programa de Pós-Graduação em Docência para a Educação Básica - Mestrado Profissional, pela Faculdade de Ciências da Universidade Estadual Paulista "Júlio de Mesquita Filho" - UNESP, Campus Bauru-SP. A dissertação e o produto intitulados, respectivamente: "Diálogos e práticas coma Cultura Corporal na Educação Infantil: crianças de zero a três anos"1 e "Cultura Corporal na Educação Infantil: possibilidades didáticas" 2 trazem uma reflexão sobre o desenvolvimento de interações e ações pedagógicas no âmbito da área do conhecimento da Cultura Corporal, com crianças de zero a três anos de idade.

1 PEREIRA, A. C. S. Diálogos e práticas com a Cultura Corporal na Educação Infantil: crianças de zero a três anos. Orientadora: Fernanda Rossi. 2020. 226f. Dissertação (Mestrado em Docência para a Educação Básica) - Faculdade de Ciências, Universidade Estadual Paulista. Bauru, 2020.

2 PEREIRA, A. C. S.; ROSSI, F. Cultura Corporal na Educação Infantil: possibilidades didáticas. Bauru: UNESP/FC, 2020. Disponível em: https://issuu.com/emanoel_eb/docs/cultura_ corporal_na_educa_o_infantil_possibilidad 
As discussões ora apresentadas estão fundamentadas nos estudos acima e na Proposta Pedagógica para a Educação Infantil do município de Bauru-SP, que tem como base teórica a pedagogia histórico-crítica e a psicologia histórico cultural, representadas por seus principais teóricos, Dermeval Saviani e Lev Semenovich Vigotski, e também em artigos e pesquisas relevantes para área do conhecimento de Cultura Corporal. Desta forma, abordaremos algumas reflexões sobre o corpo e o movimento e a importância das atividades com a Cultura Corporal na Educação Infantil, com bebês e crianças bem pequenas, situando a teoria como elemento fundante da prática pedagógica.

A Proposta Pedagógica para a Educação Infantil 16 de Bauru, firmada em sólido referencial teórico, concebe a infância como uma época de importante desenvolvimento social, afetivo, motor ecognitivo para a criança. Assim, o documento defende a socialização dos conhecimentos filosóficos, artísticos e científicos produzidos pela humanidade, sendo a escola responsável pela qualidade das mediações desses conhecimentos, e a mediação do(a) professor(a) fundamental no processo de desenvolvimento e aprendizagem da criança, garantindo, assim, o acesso ao saber elaborado (BAURU, 2016).

Para a psicologia histórico-cultural compreender a natureza do processo de desenvolvimento infantil, suas fases e períodos, bem como o papel da cultura na constituição do psiquismo, faz 
toda a diferença na orientação do planejamento do trabalho educativo com a criança (BAURU, 2016), assim como para a pedagogia históricocrítica considerar a "tríade conteúdo/forma/ destinatário, ou seja, conteúdo (o que é ensinado de forma intencional e científica); forma (o modo como é ensinado); e o destinatário (para quem é ensinado)", considerando as particularidades desta etapa educacional, promove o desenvolvimento infantil em suas máximas possibilidades (PEREIRA; ROSSI, 2020, p. 10).

Para cada fase de desenvolvimento da criança, há uma atividade guia dominante ${ }^{3}$, ou seja, "aquela responsável pela formação e reorganização dos processos psíquicos centrais de um dado período do desenvolvimento" (BAURU, 2016, p. 103). Para a primeira infância (0 a 3 anos), de acordo com a periodização (períodos de desenvolvimento psíquico do ser humano) do desenvolvimento da criança, proposta por Daniil B. Elkonin ${ }^{4}$, temos dois períodos marcantes: Primeiro ano (0 a 1 ano) e Primeira Infância (1 a 3 anos).

No Primeiro ano, temos como atividade dominante a comunicação emocional direta. Aqui 3 Para saber mais sobre periodização do desenvolvimento psíquico e ações educativas acesse a Proposta Pedagógica para a Educação Infantil do Município de Bauru-SP, nas páginas 101-148. Disponível em: http://www2.bauru.sp.gov.br/ arquivos/arquivos_site/sec_educacao/proposta_pedagogica_ educacao_infantil.pdf

4 Daniil Borisovich Elkonin (1904-1984), psicólogo soviético, conhecido no Brasil por seu livro Psicologia do jogo. 
há uma relação predominante entre adulto-social e criança, por meio da qual o adulto empresta seu psiquismo para o bebê, empresta sua voz, seu olhar, sua compreensão do mundo, apresentando à criança os elementos da cultura como objetos, ideias, pensamentos etc.

$\mathrm{Na}$ primeira infância, na qual a atividade dominante da criança é a atividade objetal manipulatória, o adulto fica em segundo plano, mas não menos importante. Agora a relação é criança e objeto social, sendo que ela irá explorar os objetos e descobrir suas qualidades e é o adulto quem apresentará o mundo das coisas às crianças. Assim, neste período de zero a três anos, a criança irá se relacionar alternadamente entre o mundo 18 das coisas e o mundo das pessoas (BAURU, 2016). Pereira (2020, p. 40) ressalta que "vale lembrar que, apesar do papel importante do adulto nesse momento, a criança também aprende com seus pares e na brincadeira", sendo a escola um lugar propício para o aprendizado.

Ressaltamos que a brincadeira e o movimento fazem parte do universo infantil. Desta forma, a escola de Educação Infantil, primeira etapa da educação básica, prima pela socialização dos conhecimentos filosóficos, artísticos e científicos produzidos pela humanidade e traduzidos em diferentes linguagens: oral, corporal, musical, gráfico-pictórica e plástica (GARANHANI; NADOLNY, 2015). Ideia também defendida por Kishimoto (2010): 
Para a criança, o brincar é a atividade principal do dia-a-dia. É importante porque dá a ela o poder de tomar decisões, expressar sentimentos e valores, conhecer a si, aos outros e o mundo, de repetir ações prazerosas, de partilhar, expressar sua individualidade e identidade por meio de diferentes linguagens, de usar o corpo, os sentidos, os movimentos, de solucionar problemas e criar. Ao brincar, a criança experimenta o poder de explorar o mundo dos objetos, das pessoas, da natureza e da cultura, para compreendê-lo e expressálo por meio de variadas linguagens (KISHIMOTO, 2010, p. 1).

Corroborando com este pensamento, Pereira (2020, p. 22) salienta que "por meio da brincadeira

a criança desenvolve suas funções cognitivas e motoras, a linguagem, a percepção, a memória e o afeto contribuindo para o processo de apropriação de signos sociais", conquistando o autodomínio de sua conduta, pois pelo brincar ela se comunica e aprende sobre as qualidades dos objetos, das ações sociais e da natureza e o corpo tem papel fundamental neste processo.

A comunicação e a exploração dos objetos que estão no mundo acontecem por meio do corpo. O movimento corporal possibilita o conhecimento do mundo e permite expressar o pensamento da criança, suas ações e relações com pessoas e objetos (PEREIRA, 2020, p. 40). 
A Base Nacional Comum Curricular - BNCC $^{5}$ complementa esta ideia destacando que "na infância o corpo das crianças ganha centralidade, pois ele é o partícipe privilegiado das práticas pedagógicas". Portanto, na escola, por meio das vivências, brincadeiras e das variadas situações de aprendizagem as crianças ampliam seu repertório de "movimentos, gestos, olhares, sons e mímicas com o corpo, para descobrir variados modos de ocupação e uso do espaço com o corpo" (BRASIL, 2017, p. 39).

Desta forma, abordar a Cultura Corporal para bebês e crianças bem pequenas é desafiador! Partimos do princípio de que o bebê está num processo de descoberta do próprio corpo e de 20 exploração dos movimentos, assim, desenvolver um trabalho pedagógico, no qual o corpo e o movimento são os eixos centrais, promove novas experiências, sensações e percepções deste corpo e suas relações com as pessoas e os objetos. Outrossim, compreendemos que o trabalho educativo com o corpo possibilita à criança o desenvolvimento de sua personalidade, autonomia e identidade, dando um destaque especial ao trabalho com a Cultura Corporal desde o início da vida.

Esperamos que o leitor tenha um novo olhar sobre corpo e movimento a partir da leitura desse capítulo que trará, além da teoria, experiências práticas e possíveis de realizar com bebês e crianças 5 Documento elaborado para orientar o ensino no Brasil, desde a Educação Infantil até o Ensino Médio. 
bem pequenas, com a perspectiva, por fim, de potencializar uma prática educativa de qualidade.

\section{O Trabalho com a Cultura \\ Corporal na Educação INFANTIL}

Desde a condição fetal no útero as crianças se movimentam (VERDEN-ZÖLLER, 2004). De acordo com Maturana (2004), elas se comunicam pela ação e emoção, sendo que as emoções ditam as disposições do corpo e anunciam os movimentos da criança.

As disposições e movimentos corporais na infância estão relacionadas às manifestações culturais expressas no e pelo corpo ao qual denominamos Cultura Corporal. Para Daolio (2010, p. 12), o ser humano é "eminentemente cultural, contínuo construtor de sua cultura relacionada aos aspectos corporais". Pereira (2020, p. 52) acrescenta que:

Essas manifestações estão presentes no cotidiano da escola de Educação Infantil por meio das brincadeiras, nas quais a criança corre, dança, joga, gira, sobe, desce, pula, rola, rodopia, etc., enfim por meio dos diversos movimentos e das diversas expressões, gestos e linguagens corporais.

A BNCC traz a reflexão de que tanto o desenvolvimento como a aprendizagem ocorrem pelas interações e brincadeiras das crianças. Essas interações e brincadeiras acontecem por meio da garantia dos seis direitos de aprendizagem: 
conviver, brincar, participar, explorar, expressarse e conhecer-se. O documento ainda destaca cinco campos de experiência no trabalho com a Educação Infantil: o eu, o outro e o nós; corpo, gestos e movimentos; traços, som, cores e formas; escuta, fala, pensamento e imaginação; espaços, tempos, quantidades, relações e transformações (BRASIL, 2017).

Dentro da área de conhecimento da Cultura Corporal destacamos na BNCC o trabalho com o campo de experiência corpo, gestos e movimento:

Com o corpo (por meio dos sentidos, gestos, movimentos impulsivos ou intencionais, coordenados ou espontâneos), as crianças, desde cedo, exploram o mundo, o espaço e os objetos do seu entorno, estabelecem relações, expressam-se, brincam e produzem conhecimentos sobre si, sobre o outro, sobre o universo social e cultural, tornando-se, progressivamente, conscientes dessa corporeidade. Por meio das diferentes linguagens, como a música, a dança, o teatro, as brincadeiras de faz de conta, elas se comunicam e se expressam no entrelaçamento entre corpo, emoção e linguagem (BRASIL, 2017, p. 38-39).

Nesse sentido, o corpo necessita ser concebido em sua totalidade e não como mero acessório para a execução de atividades na Educação Infantil, pois ações como ler e escrever, pintar, desenhar, dançar, 
jogar, brincar, dentre outras, são possíveis porque somos corpo e não por termos corpo (MENDES; NÓBREGA, 2004).

Desta forma, a Proposta Pedagógica para a Educação Infantil do Sistema Municipal de ensino de Bauru destaca que a promoção do desenvolvimento social, emocional e físico das crianças é uma máxima para o pleno desenvolvimento humano (Bauru, 2016).

À época da construção e implementação do referido documento, ainda não havia sido publicada a versão final da BNCC. Outro ponto a ser ressaltado é que a matriz curricular da Proposta Municipal não contemplou, de modo aprofundado e sistematizado, o trabalho educativo com os bebês.

A Proposta traz como objetivo geral desta área do conhecimento para as demais crianças da Educação Infantil: "Ampliar as possibilidades de domínio consciente e voluntário das ações corporais de natureza lúdica, artística e de destreza por meio da apropriação de atividades da cultura corporal: as brincadeiras de jogo, de dança e de ginástica, entre outras", apresentando três eixos de conteúdos a serem trabalhados: Brincadeiras de situações opositivas; Brincadeiras de destrezas e desafios corporais; e Brincadeiras de imitação e criação de formas artísticas (BAURU, 2016, p. 410).

O eixo "Brincadeiras de situações opositivas" apresenta como objetivo "aceitar a oposição corporal do outro buscando criar ações corporais que superem a oposição do outro e/ou criem uma 
oposição para o outro" (BAURU, 2016, p. 413). No entanto, ao analisar as propostas deste eixo, Pereira (2020) destaca que:

[...] este eixo "Brincadeiras de situações opositivas" não contempla atividades pertinentes para os bebês de até um ano; algumas brincadeiras podem começar a ser introduzidas ao final do segundo ano de vida, porém a criança pequena ainda não dispõe de repertórios de movimentos e ações para participarem ativamente destas brincadeiras (PEREIRA, 2020, p. 55-56).

O eixo "Brincadeiras de destrezas e desafios corporais" tem como objetivo "aceitar desafiar-se corporalmente, buscando novas possibilidades de destrezas para si (metas possíveis)" (BAURU, 2016, p. 415). E o eixo "Brincadeiras de imitação e criação de formas artísticas" trazem o objetivo de "criar uma dimensão estética e artística com as ações corporais a fim de mostrar uma determinada forma ou imagem com os movimentos corporais" (p. 416).

Pereira e Rossi (2020, p. 13-14) ao analisarem esta área do conhecimento na Proposta Pedagógica para a Educação Infantil do município de Bauru reconheceram a "ausência de conteúdos ${ }^{6}$, bem como de orientações didáticas pertinentes a esta faixa etária dos bebês (zero a um ano e 6 A matriz curricular da Proposta Pedagógica para a Educação Infantil do município de Bauru inicia a partir da idade de um ano e oito meses. No município, a turma correspondente a esta faixa etária é o Infantil II. 
sete meses)", surgindo assim, a necessidade de elaboração de um novo eixo de conteúdos para a área de conhecimento da Cultura Corporal na Educação Infantil: o eixo de "Brincadeiras de percepções sensoriais" ${ }^{\prime \prime}$. Esse eixo foi criado pelas pesquisadoras pensando nas especificidades dos bebês, apresentando como objetivo: "sentir, conhecer e reconhecer o mundo por meio dos cinco órgãos do sentido (visão, audição, olfato, paladar e tato), num movimento constante de apropriação e construção da cultura".

Apresentaremos a seguir algumas ações pedagógicas possíveis de serem realizadas com os bebês e crianças bem pequenas, com ênfase nesta área de conhecimento denominada Cultura Corporal nas escolas de Educação Infantil.

\section{As Interações e Ações Pedagógicas com Bebês e Crianças Bem Pequenas}

As interações e ações pedagógicas apresentadas a seguir foram desenvolvidas em uma Escola Municipal de Educação Infantil Integral da cidade de Bauru-SP, onde uma das pesquisadoras trabalhou nos anos de 2018 e 2019 e possibilitou a vivência prática dos estudos teóricos, buscando indissociar teoria e prática em todo o processo. Para esta faixa

7 Destacamos que nos últimos dois anos foi formado um grupo de trabalho no município de Bauru para a elaboração de um currículo para o berçário (bebês de 0 a 1 ano), ainda em processo de publicação ao qual o material de nossa pesquisa de mestrado (PEREIRA, 2020; PEREIRA; ROSSI, 2020) contribuiu significativamente com esta área do conhecimento. 
etária (0 a 1 ano e 7 meses) que corresponde as turmas Infantil e Infantil I (antigamente denominada Berçário) participaram da pesquisa oito auxiliares de creche $^{8}$ e 21 bebês.

Foram elaboradas e desenvolvidas interações e ações pedagógicas por meio de brincadeiras, pois o lúdico é intrinsecamente ligado ao universo infantil. De acordo com Pereira (2020, p. 41), "a ludicidade faz parte do processo de ensino e aprendizagem na Educação Infantil", sendo "imprescindível conhecer esse universo lúdico para que haja um bom desenvolvimento do trabalho pedagógico".

Entendendo que a criança não nasce sabendo brincar, sendo esta uma prática social, destacamos a relevância da mediação do adulto nos anos 26 iniciais da Educação Infantil, pois a brincadeira necessita ser aprendida e, por meio das interações com o adulto, os objetos, os brinquedos e também com seus pares, a criança aprende e cria novas brincadeiras, bem como suas regras.

Todo o período da educação infantil é importante para a introdução das brincadeiras. Pela diversidade de formas de conceber o brincar, alguns tendem a focalizá-lo como característico dos processos imitativos da criança, dando maior destaque apenas ao período posterior aos dois anos

8 Não há no município de Bauru, até o momento, o(a) professor(a) de Educação Infantil para as turmas Infantil e Infantil I (berçário). O trabalho no berçário é conduzido pelas auxiliares de creche. 
de idade. O período anterior é visto como preparatório para o aparecimento do lúdico. No entanto, temos clareza de que a opção pelo brincar desde o início da educação infantil é o que garante a cidadania da criança e ações pedagógicas de maior qualidade (KISHIMOTO, 2010, p. 1).

Deste modo, as brincadeiras elaboradas tiveram como base os eixos de conteúdos contemplados na Proposta Pedagógica para a Educação Infantil do município de Bauru, a saber: Brincadeiras de situações opositivas; Brincadeiras de destrezas e desafios corporais; Brincadeiras de imitação e criação de formas artísticas; e, também, o eixo elaborado pelas pesquisadoras (PEREIRA; ROSSI, 2020): Brincadeiras de Percepções Sensoriais, entendendo a relevância da percepção sensorial para a criança, pois, como enfatiza Kaercher (2001, p. 84), "tudo que puder ser cheirado, ouvido, visto, tocado ou saboreado terá uma grande importância" na construção do conhecimento na infância.

"O primeiro ano de vida do bebê é muito importante para o seu desenvolvimento" (PEREIRA; ROSSI, 2020, p. 20). Assim, as ações exploratórias de seu próprio corpo permitem o autoconhecimento e a descoberta de seus limites, a fim de avançar na experiência do movimentar-se em busca do autodomínio de sua conduta. Também a organização do espaço e disposições dos objetos devem ser pedagogicamente pensados visando a segurança e a acessibilidade dos bebês. 
Ainda, destacamos a importância de os adultos observarem as preferências das crianças nas brincadeiras, ou seja, com o que gostam de brincar, em quais ambientes, como brincam, qual o seu interesse etc., observando sua linguagem, gesto, olhar, choro, a fim de promovervariadas situações de interações sociais que promovam desenvolvimento e aprendizagem (BARBOSA; HORN, 2001).

A seguir, eis algumas ações pedagógicas ${ }^{9}$ possíveis, conforme os eixos da Cultura Corporal supracitados:

Eixo: Brincadeiras de Percepções Sensoriais

Para Pereira e Rossi (2020, p. 14) “a percepção sensorial é fundamental no trabalho desenvolvido com as crianças pequenas, pois os bebês conhecem

28 o mundo por meio dos seus cinco sentidos (visão, olfato, paladar, audição e o tato)", principalmente as crianças de até dois anos. Ideia também defendida por Kaercher (2001) que ressalta a importância dos sentidos para apreensão das informações e compreensão do mundo pela criança.

Em todas as atividades apresentadas a seguir o adulto preparará com antecedência os materiais e ao apresentá-los às crianças nomeará os objetos, alimentos, sensações produzidas, dentre outros, explorando suas qualidades (cores, texturas,

9 Para saber mais acesse o material constante no livro: PEREIRA, A. C. S.; ROSSI, F. Cultura Corporal na Educação Infantil: possibilidades didáticas. Bauru: UNESP/FC, 2020. Disponível em: https://issuu.com/emanoel_eb/docs/cultura_ corporal_na_educa_o_infantil_possibilidad 
tamanhos, sabores etc.) estimulando a criança a participar da atividade.

\section{CaIXas Mágicas}

Destacamos nesta atividade o trabalho com diversos materiais: argila, barro, areia mágica, gelatina, massa de modelar, macarrão, dentre outros que possibilitem a experimentação, tátil, gustativa, olfativa, auditiva e visual pelas crianças com o objetivo de sentir, ver e cheirar, conhecer e reconhecer as texturas, temperaturas e cores, tocar, apertar, amassar e brincar com os materiais das caixas. Os materiais podem ser apresentados dentro ou fora da caixa.

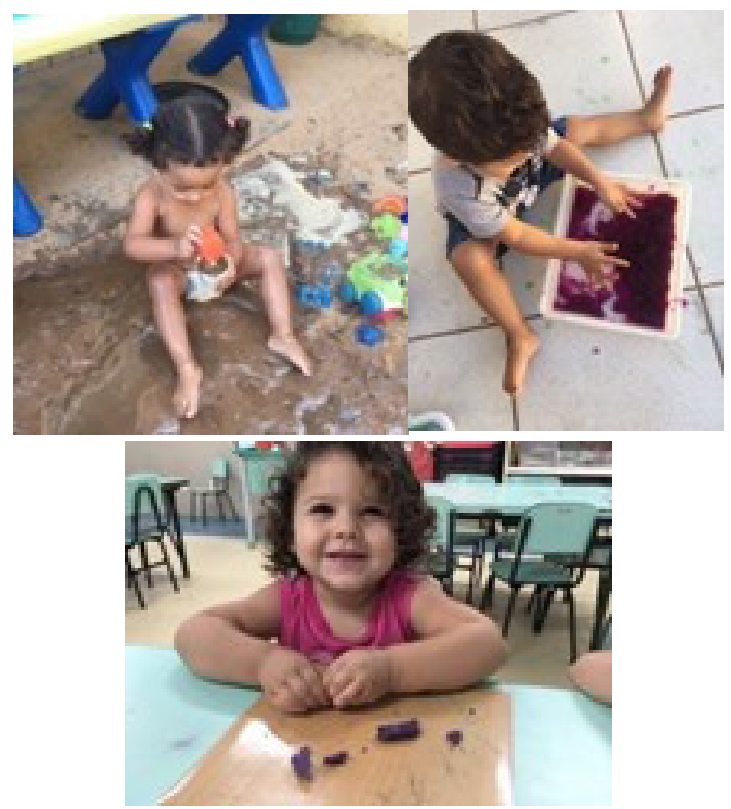

Fonte: Pereira; Rossi (2020) 


\section{Tapete Sensitivo}

Aqui destacamos o trabalho com materiais diversificados como: lixa, algodão, areia, folhas de árvores, bucha, macarrão, sagu, EVA, tampinhas de garrafa pet, água fria e quente etc., que permitam a criança experienciar diversas texturas e temperaturas por meio do tato (pés e mãos), descobrindo e brincando com os elementos da cultura (objetos) e elementos da natureza. O adulto prepara os tapetes que estarão à disposição da criança para que ele possa andar, sentar, engatinhar, rolar e tocar com as mãos e pés.

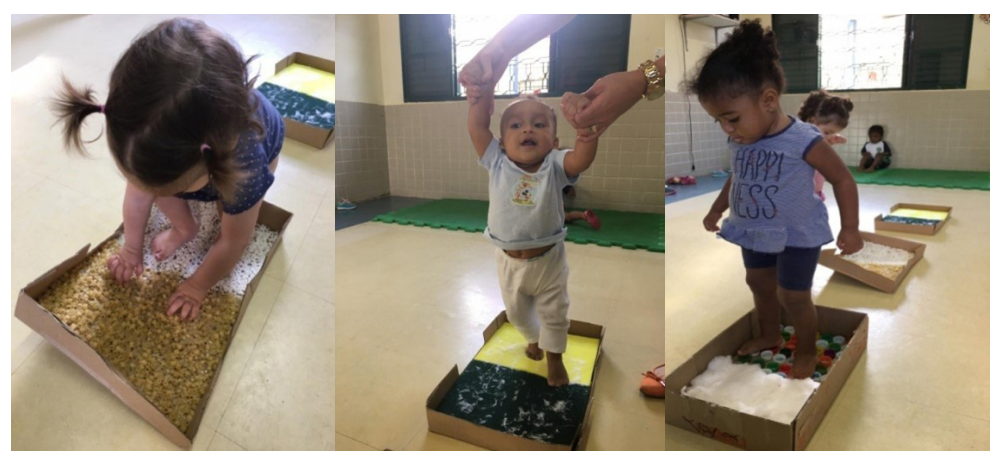

Fonte: Pereira; Rossi (2020)

\section{Come-Come}

Nesta atividade apresentamos às crianças alimentos variados (azedo, doce, salgado, amargo, duro, mole, quente, frio etc.), com o objetivo de estimular a percepção dos sentidos do paladar, do olfato e do tato por meio do oferecimento de alimentos com texturas, temperaturas, cheiros e 
sabores diversificados. As crianças irão manipular os alimentos, pegando com as mãos, cheirando e levando à boca para comer. Os adultos participarão da atividade nomeando os alimentos e as sensações produzidas por eles, para as crianças.

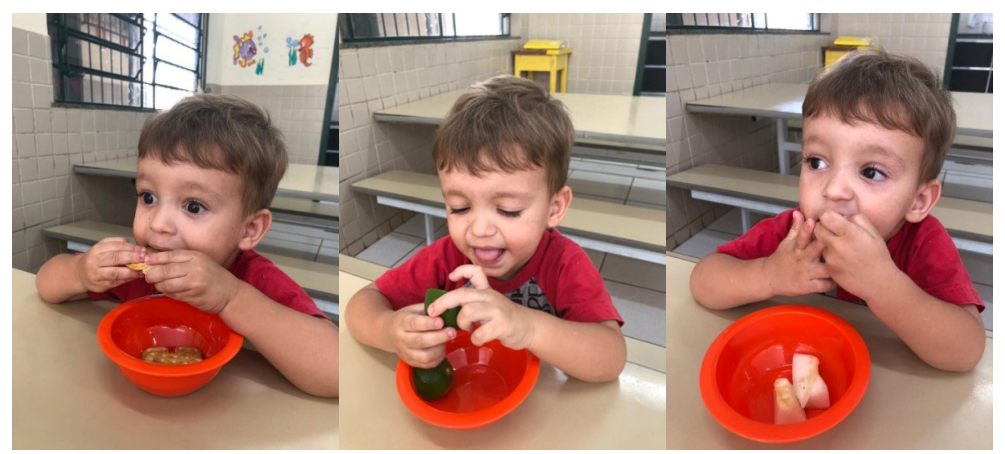

Fonte: Pereira; Rossi (2020)

Eixo: Brincadeiras de Destrezas e Desafios Corporais

Neste eixo exploramos as possibilidades e limites de movimentos nas ações corporais da criança, desde as ações mais simples até aquelas mais complexas, a fim de promover a conquista de sua destreza corporal, sempre por meio da ludicidade, explorando o brincar e os brinquedos que fazem parte da cultura infantil, evitando ações repetitivas e monótonas que não fazem sentido para a criança (BAURU, 2016; PEREIRA; ROSSI, 2020).

\section{Cama de Gato}

Nesta brincadeira o adulto preparará o espaço com barbantes ou fitas, entrelaçando-os a fim de 
propor vários níveis de dificuldade para a criança passar por eles, desenvolvendo as habilidades motoras de pular, saltar, abaixar, rolar, rastejar, engatinhar, esquivar-se, bem como o equilíbrio corporal etc. A ideia é oferecer vários desafios para a criança superar, de modo que a faça testar os limites e pensar maneiras de atravessar a cama de gato como: passar rastejando, rolando, engatinhando por baixo ou passar por cima/pular.

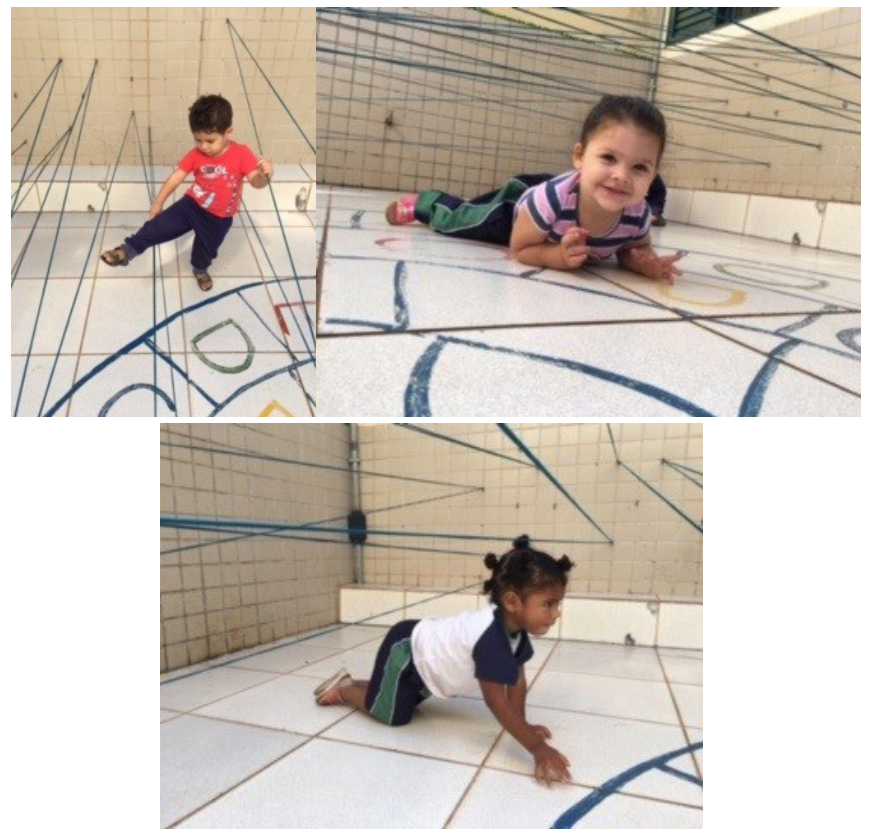

Fonte: Pereira; Rossi (2020)

\section{Pula-Pula Divertido}

Aqui, buscamos novos desafios e novas possibilidades de destrezas para a criança por 
meio do desenvolvimento das habilidades motoras básicas de sentar, andar, pular, virar cambalhota, rolar, engatinhar, subir, descer etc., tendo a ludicidade como eixo da atividade. A maioria das escolas possuem o centro de atividades para esta finalidade, caso não haja, sugerimos que seja criado o espaço com colchões, bancos, cadeiras, almofadas, sofás etc., conforme as fotos.

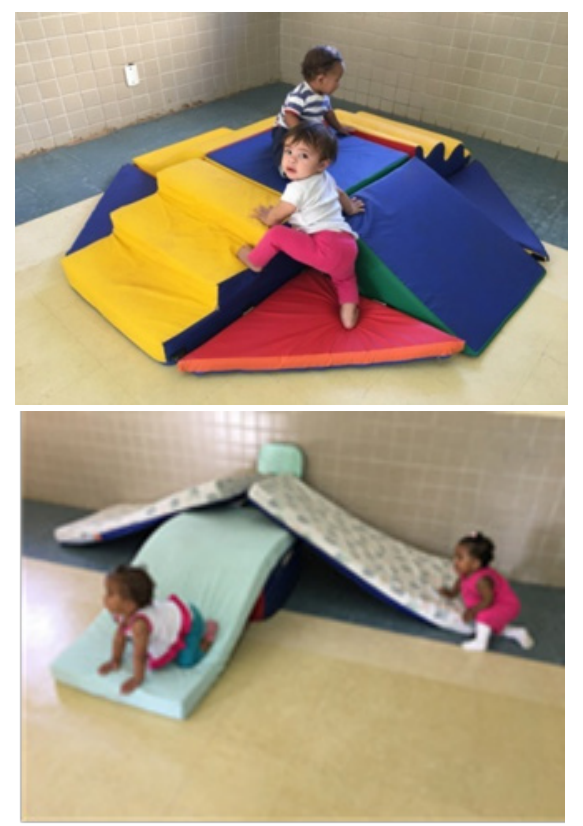

Fonte: Pereira; Rossi (2020)

Você E Eu

Conhecer o próprio corpo, sentir suas capacidades e limitações para locomover-se, buscar novas possibilidades de destrezas para si e o 
desenvolvimento da afetividade adulto-criança é o foco desta atividade que trabalha com a expressão corporal, esquema corporal, relação interpessoal, habilidades motoras básicas de sentar, virar, rolar, engatinhar, pegar, soltar etc., coordenação motora global e fina, utilizando brinquedos. A intenção aqui é estimular o bebê para que direcione 0 olhar e o corpo para diferentes pontos e que tente alcançar os objetos pelo movimentar do corpo (rolar, virar, sentar, arrastar-se, engatinhar, andar, mastigar, pegar, soltar, levantar etc.). Para isso, o adulto deverá conversar com o bebê com tom de voz agradável, estimulando-o a executar os movimentos solicitados, e serão dispostos objetos coloridos, sonoros, macios, próprios para a idade, para que a criança se interesse em pegá-lo.

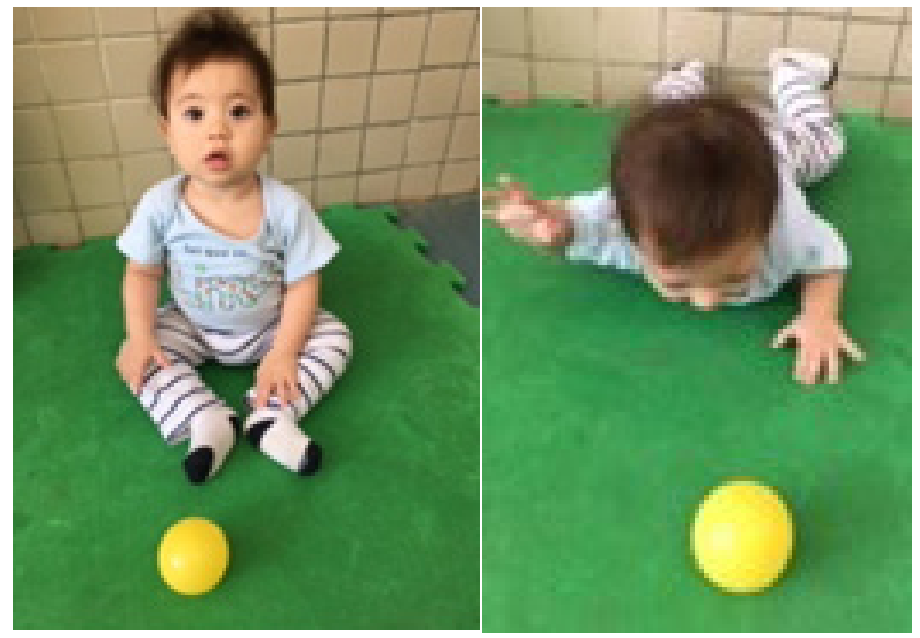




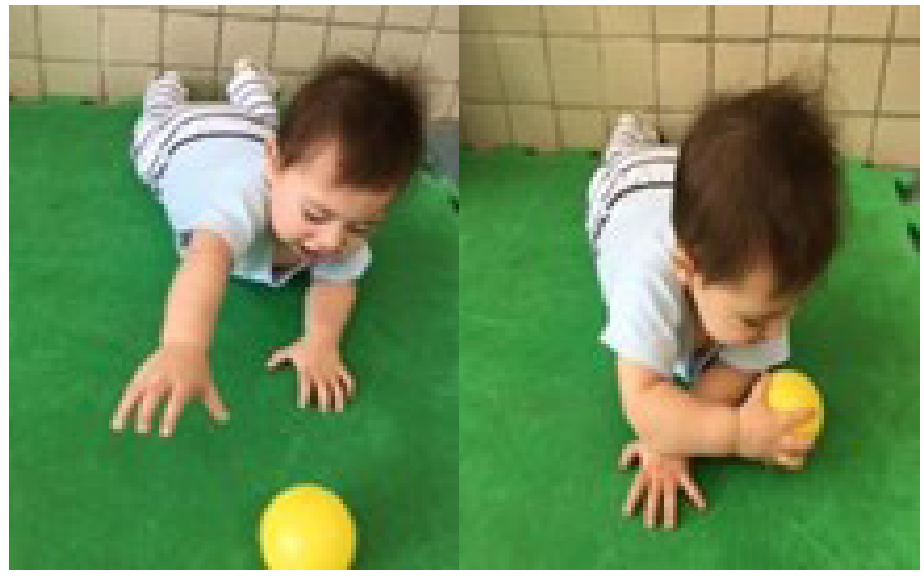

Fonte: Pereira; Rossi (2020)

EIXo: Brincadeiras de IMITAÇÃo

e Criação de Formas Artísticas

No eixo brincadeiras de imitação e criação de

formas artísticas a criança brinca com seu corpo explorando formas corporais que permitam ver a beleza que existe em cada movimento. Assim, por meio de suas ações intencionais ampliam qualitativa e quantitativamente seus movimentos corporais infantis (BAURU, 2016).

\section{Rosto Divertido}

Reconhecer-se através do espelho cria uma dimensão estética com os movimentos faciais e corporais e permite a criança explorar as possibilidades de caretas e gestos variados com seu próprio corpo. Nesta atividade, o adulto vai nomeando as expressões, os sentimentos e as 
emoções que forem surgindo no decorrer da vivência, que pode ser feito com ou sem música para estimular as expressões.

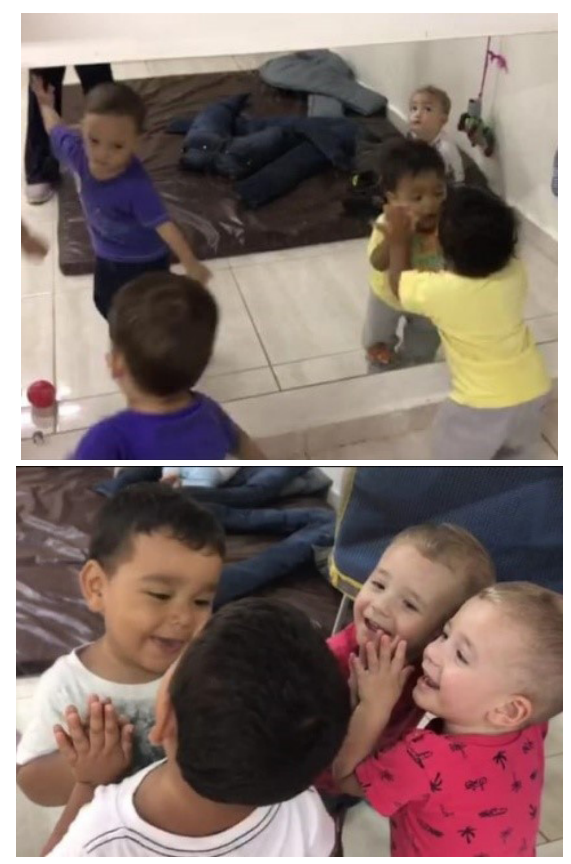

Fonte: Pereira; Rossi (2020)

\section{Pequenos Artistas}

Nesta atividade propomos uma brincadeira com tinta creme $^{10}$ e cores variadas para que as 10 A tinta creme é uma espécie de mingau cremoso que permite a criança deslizar nos movimentos pela sua textura. Receita: 4 copos de água, 1 copo de farinha de trigo, 1 colher (sopa) de sal e 2 colheres (sopa) de açúcar. Misturar todos os ingredientes e levar ao fogo para cozinhar até alcançar o ponto de mingau. Desligar e esperar esfriar para usar. Adicionar corante da cor que desejar. 
crianças explorem as cores e as possibilidades de movimentos ao deslizarem sobre a tinta, criando uma dimensão estética com o corpo a fim de produzir suas marcas corporais e sua imagem. Pode ser feita direto num piso de textura lisa ou em papéis amplos. Se feita em folhas, deixe secar e depois risque o contorno do corpo da criança, recorte e cole em caixas para que ela perceba as dimensões reais de seu corpo.

Num primeiro momento colocar somente a tinta creme (incolor) para que a criança sinta sua textura (pode causar estranhamento para o bebê, se isso ocorrer converse com ele e estimule-o a tocar na tinta, ofereça modelos de movimentos), em seguida acrescente as cores, uma de cada de vez e deixe o bebê espalhar a tinta usando todo o corpo (mãos e braços, pernas e pés, rolando de um lado para o outro, engatinhando etc.; evite andar, pois a tinta é muito escorregadia). O adulto também pode explorar e nomear as partes do corpo nesta atividade.

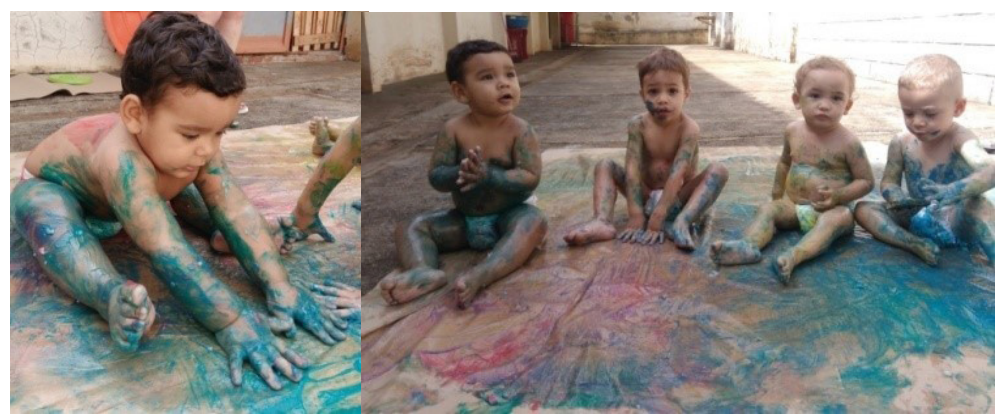




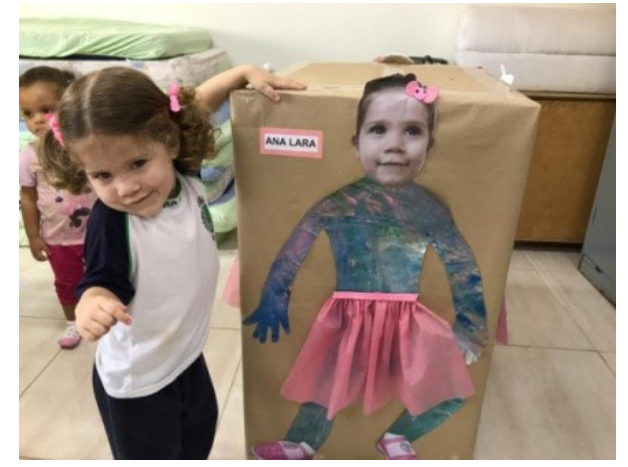

Fonte: Pereira; Rossi (2020)

\section{Eixo: Brincadeiras de Situações Opositivas}

Este eixo trabalha com as ações corporais opositivas que criam nas crianças uma tensão lúdica que faz com que elas busquem soluções para 38 resolver os problemas surgidos na brincadeira, como por exemplo, brincadeiras que criam situações de perseguição e fuga, na qual a criança precisa de estratégias para não ser pega ou para pegar seu adversário (BAURU, 2016).

No entanto, de acordo com análise feita por Pereira e Rossi (2020), as crianças de até um ano não dispõem de repertórios de ações e movimentos corporais para participarem de tais atividades. Essas são atividades para serem introduzidas quando a criança já conquistou alguma independência em sua locomoção, como andar e correr com boa desenvoltura, por exemplo. Assim, a atividade a seguir é recomendada para bebês acima de 18 meses. 


\section{Pega-Pega}

Nesta atividade propomos a introdução da brincadeira de pega-pega com o objetivo de a criança vivenciar brincadeiras com as habilidades motoras de andar, correr, se esquivar e equilibrarse, propiciando a elas a ampliação do domínio consciente de suas ações corporais, o que oportuniza a superação de desafios em sua locomoção.

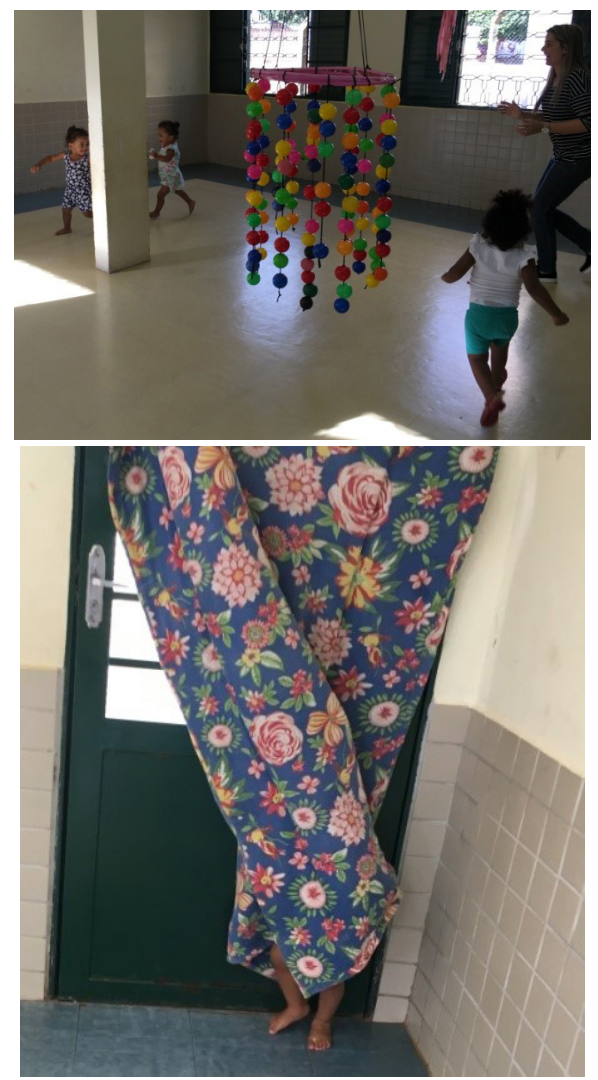

Fonte: Pereira; Rossi (2020) 


\section{Considerações Finais}

As interações e ações pedagógicas que concebem o corpo e o movimento infantis nos processos de aprendizagem, contribuem, desde o início da vida, para a formação da identidade, personalidade, autonomia e conquista do autodomínio da conduta das crianças.

Levando em consideração que o primeiro ano de vida e a primeira infância são fases da vida de muito aprendizado, este capítulo buscou fundamentar a importância do trabalho educativo na área do conhecimento da Cultura Corporal com o entrelaçamento da teoria e da prática, de modo a propiciar às crianças a "apropriação e ampliação do repertório da Cultura Corporal, por meio de 40 experiências corporais mediadas pela ludicidade, expressão de gestos e fruição artística e estética do brincar". Nesse sentido, é oportunizado às crianças o desenvolvimento do "conhecimento de si, a percepção sensorial, o domínio consciente de seu corpo, as possibilidades de movimentar-se, o vínculo afetivo, a curiosidade, a criatividade e a imaginação" (PEREIRA; ROSSI, 2020, p. 8).

Encerrando este capítulo, concluímos que essas interações e ações pedagógicas, tendo o corpo e o movimento como eixos centrais, têm um papel fundamental no desenvolvimento e aprendizagem das crianças, pois nas brincadeiras e no brincar são desenvolvidas as funções cognitivas e motoras tão importantes no desenvolvimento infantil, 
contribuindo também para o aperfeiçoamento da linguagem, memória e pensamento num processo constante de apropriação de signos sociais.

Assim, contribuímos com reflexões sobre as ações educativas com intencionalidade com bebês e crianças bem pequenas, despertando novos olhares para as possibilidades de interações e ações pedagógicas possíveis de serem realizadas, a fim de promover o desenvolvimento e a aprendizagem na área do conhecimento de Cultura Corporal, sem nenhuma pretensão de esgotarmos as propostas para o trabalho pedagógico, tão rico em possibilidades.

\section{REFERÊNCIAS}

BARBOSA, M. C. S.; HORN, M. G. S. Organização do Espaço e do Tempo na Escola de Educação Infantil. In: CRAIDY, C. M; KAERCHER, G. E. P. S. (Org.). Educação Infantil: pra que te quero? Porto Alegre: Artmed, 2001, p. 67-80.

BRASIL. Ministério da Educação. Base Nacional Comum Curricular. Brasília: MEC/SEB, 2017.

DAOLIO, J. Educação física e o conceito de cultura. 3. ed. Campinas, SP: Autores Associados, 2010.

GARANHANI, M. C; NADOLNY, L. F. A Linguagem movimento na educação de bebês para a formação de professores. Educação \& Realidade, Porto Alegre, v. 40, n. 4, out./dez. 2015, p. 1005-1026. Disponível em: http://dx.doi.org/10.1590/2175-623651737. Acesso em: 25 jun. 2021. 
KAERCHER, G. E. E por falar em literatura. In: CRAIDY, C. M; KAERCHER, G. E. P. S. (Org.). Educação Infantil: pra que te quero? Porto Alegre: Artmed, 2001, p. 81-87.

KISHIMOTO, T. M. Brinquedos e brincadeiras na educação infantil. In: I Seminário Nacional: Currículo em movimento, perspectivas Atuais, 1., 2010, Belo Horizonte. Anais do I Seminário Nacional: currículo em movimento. Perspectivas atuais. Belo Horizonte: Universidade Federal de Minas Gerais, 2010. v. 1. p. 1-20. Disponível em: http://portal. mec.gov.br/docman/dezembro-2010-pdf/7155-23-brinquedosbrincadeiras-tizuko-morchida/file. Acesso em: 25 jun. 2021.

MATURANA, $H$. Conversações matrísticas e patriarcais. In: MATURANA, H.; VERDEN-ZÖLLER, G.

42 (org.). Amar e brincar: fundamentos esquecidos do humano do patriarcado à democracia. São Paulo: Palas Athena, 2004, p. 25-115.

MENDES, M. I. B. de S.; NÓBREGA, T. P. Corpo, natureza e cultura: contribuições para a educação. Revista Brasileira de Educação, n. 27, set./dez. 2004. p. 125-137.

PASQUALINI, J. C.; TSUHAKO, Y. N. Proposta pedagógica para a Educação Infantil do Sistema Municipal de Ensino de Bauru/SP [recurso eletrônico], orgs. Bauru: Secretaria Municipal de Educação, 2016.

PEREIRA, A. C. S. Diálogos e práticas com a Cultura Corporal na Educação Infantil: crianças de zero a três anos. Orientadora: Fernanda Rossi. 2020. 226f. Dissertação (Mestrado em Docência para a Educação Básica) - Faculdade de Ciências, Universidade Estadual Paulista. Bauru, 2020. 


\section{PEREIRA, A. C. S.; ROSSI, F. Cultura Corporal}

na Educação Infantil: possibilidades didáticas. Bauru: UNESP/FC, 2020. Disponível em: https://issuu. com/emanoel_eb/docs/cultura_corporal_na_educa__o_ infantil_possibilidad

VERDEN-ZÖLLER, G. Obrincar narelação maternoinfantil. In: MATURANA, H.; VERDEN-ZÖLLER, G. Amar e brincar: fundamentos esquecidos do humano do patriarcado à democracia. São Paulo: Palas Athena, 2004, p. 117-216. 





\title{
A EDUCAÇÃO INFANTIL FOI CONCLUÍDA... COMO PROSSEGUIR? A CONTINUIDADE DO BRINCAR E APRENDER
}

\author{
Janaina Fernanda Gasparoto Fusco \\ Keila Cristina Armando de Moraes
}

\section{CONTEXTo HistóRICO}

A criança e seus direitos, a política de Educação Infantil, as diferentes práticas e as alternativas de formação vêm ocupando os debates educacionais e a ação de movimentos sociais no Brasil nos últimos 20 anos.

A Educação Infantil é, desde a Constituição de 1988, direito das crianças, dever do Estado e da família e, à partir da LDB de 1996, a primeira etapa da educação básica.

O contexto político nacional está intrínseco nas lutas em torno da Constituinte de 1988, do Estatuto da Criança e do Adolescente (BRASIL, 1990) e da Lei de Diretrizes e Bases da Educação Nacional (BRASIL, 1996), e as discussões em torno da atuação do Ministério da Educação nos anos de 1990 como parte de uma história coletiva de intelectuais, militantes e movimentos sociais.

Em meados de 1970, as políticas educacionais voltadas à educação de crianças de 0 a 6 anos defendiam a educação compensatória de carências culturais, deficiências linguísticas e defasagens afetivas das crianças provenientes das camadas 
populares. Influenciados por orientações deagências internacionais e por programas desenvolvidos nos Estados Unidos e na Europa, os documentos oficiais dos então, denominados Ministério da Educação e Cultura (MEC) e pareceres do Conselho Federal de Educação, defendiam a ideia de que a pré-escola poderia, por antecipação, salvar a escola dos problemas relativos ao fracasso escolar.

Pela primeira vez na história da educação brasileira foi formulada uma política nacional de Educação Infantil, processo desencadeado com a Constituição de 1988, e com a ação do MEC no breve período de 1994-1995. Nos últimos anos, mesmo no quadro nacional de desmobilização da sociedade civil, a luta pela educação da infância 48 permanece, nos fóruns estaduais, na rede de creches e nos interfóruns, organizados para encaminhar de modo coletivo questões centrais da política de Educação Infantil.

Em continuidade ao processo histórico desta etapa de ensino, após um longo período de estudos, portarias e diferentes versões da elaboração da Base Nacional Comum Curricular-BNCC (BRASIL, 2017), em dezembro de 2017 acontece a Publicação do Parecer CNE/CP 15/2017, que tem sua aprovação e a Resolução CNE/CP 2/2017, que institui e orienta sua implantação. Em março de 2018, o MEC publica a versão homologada.

Segundo o artigo 210 da Constituição Federal (BRASIL, 1988), são fixados conteúdos mínimos para o Ensino Fundamental, de maneira a 
assegurar a formação básica comum [...] e o artigo 26 da LDB 9.394/96 (BRASIL, 1996) que considera que os currículos da Educação Infantil, do Ensino Fundamental e Médio devem ter base nacional comum, a ser complementada em cada sistema de ensino e em cada estabelecimento escolar, concluindo que a BNCC apresenta $\mathbf{O}$ QUE ensinar para cada ano. O currículo deve apresentar, além dos princípios do sistema/escolas, o COMO ensinar, ou seja, quais as estratégias metodológicas mais adequadas para o desenvolvimento daquilo que está sendo proposto na BNCC, considerando os eixos de interações e brincadeiras, os princípios éticos, políticos e estéticos, a indissociabilidade entre o cuidar e educar e principalmente, considerar a criança como ser integral que se relaciona com

o mundo a partir do seu corpo em vivências concretas com diferentes parceiros em diferentes linguagens. Para que a construção do currículo seja legítima e todos se sintam representados, é importante contar com a participação dos representantes da sociedade civil.

A BNCC, por ser um documento que define as habilidades essenciais para todos os alunos da Educação Básica, determina que a Educação Infantil é uma etapa essencial para a construção da identidade e da subjetividade das crianças, que é sujeito histórico e de direitos, que brinca, imagina, fantasia, deseja, aprende, observa, experimenta, narra, questiona e constrói sentidos sobre a natureza e sobre a sociedade, produzindo cultura. 
Seu objetivo é de garantir o acesso a processos de apropriação, de renovação e de articulação de saberes e conhecimentos, como requisito para a formação humana, para a participação social e para a cidadania, desde seu nascimento até cinco anos de idade. A BNCC também reforça que o cuidar está integrado às ações de conhecer e explorar o mundo; estabelece que a formação de vínculos proporciona segurança afetiva para a criança construir conhecimentos com o mundo e desenvolver autonomia e permite que enfrente e supere obstáculos; crianças ficam no centro do processo, mesmo em atividades dirigidas, todas devem ter tempo e espaço para serem ativas; o professordeveplanejarcuidadosamentemomentos

50 de livre exploração; propõe a instituição de uma rotina para transmitir a sensação de segurança e ajuda no desenvolvimento da autonomia.

De acordo com a BNCC, são estabelecidos seis Direitos de Aprendizagem: CONVIVER democraticamente, interação, diferentes linguagens, ampliação do conhecimento e o respeito em relação à natureza, à cultura, às singularidades e às diferenças entre as pessoas; BRINCAR diversas formas e com diferentes parceiros, interação com as culturas infantis, construção de conhecimentos, desenvolvimento da imaginação, criatividade, capacidades emocionais, motoras, cognitivas e relacionais; EXPLORAR movimentos, gestos, sons, palavras, histórias, objetos, elementos da natureza e do ambiente urbano e do campo, interação 
com diferentes grupos e ampliação de saberes e linguagens; PARTICIPAR do planejamento, realização das atividades recorrentes da vida cotidiana, nas brincadeiras, nos materiais e nos ambientes, desenvolvimento da linguagem e elaboração de conhecimentos; COMUNICAR / EXPRESSAR com diferentes linguagens, opiniões, sentimentos e desejos, pedidos de ajuda, narrativas de experiências, registros de vivências e de conhecimentos; CONHECER-SE e construir sua identidade pessoal ecultural, constituir umaimagem positiva de si e de seus grupos de pertencimento nas diversas interações e brincadeiras vivenciadas na instituição de Educação Infantil. Considerase que seis grandes direitos de aprendizagem devem ser garantidos a todas as crianças nas turmas de creche ou pré-escolas. Junto com estes direitos, são apresentados os cinco Campos de Experiência para a Educação Infantil, que indicam quais são as experiências fundamentais para que a criança aprenda e se desenvolvam: Eu, o outro e o nós, relacionados a construção da identidade; Corpo, gestos e movimentos, estimulando a exploração do espaço; Traços, sons, cores e formas, ressaltando manifestações artísticas, culturais e científicas; Escuta, fala, pensamento e imaginação, incentiva o desenvolvimento da linguagem oral, leitura e escrita; Espaço, tempo, quantidades, relações e transformações, desenvolvimento de noções espaciais e em relação ao tempo, de ordem temporal e histórica. 
Assim, considerando os direitos de aprendizagem e os campos de experiências, determinadas práticas sociais e culturais, múltiplas linguagens simbólicas são incluídas em sua vivência, concebendo forma de organização curricular adequada da educação da criança de até cinco anos, trabalhados de modo interativo e lúdico, promovendo a apropriação por elas de conteúdos relevantes.

Do debate sobre a educação de crianças de 0 a 5 anos nasceu a necessidade de formular políticas de formação de profissionais e de estabelecer alternativas curriculares para a Educação Infantil.

Diferentes concepções de infância, currículo e atendimento; diversas alternativas práticas, diferentes matrizes. Direitos de crianças 52 consideradas cidadãs foram conquistados legalmente sem que exista, no entanto, dotação orçamentária que viabilize a consolidação desses direitos na prática; exigências de formação de profissionais da Educação Infantil e reconhecimento de sua condição de professores. Essa diversidade também se faz presente na construção de projetos educativos para a Educação Infantil.

Dois Segmentos, um Único Percurso...

É importante pensar a creche e a escola com suas dimensões políticas, éticas e estéticas. A educação, uma prática social, inclui o conhecimento científico, a arte e a vida cotidiana. Embora a Educação Infantil e o Ensino Fundamental sejam 
frequentemente separados, do ponto de vista da criança, não há fragmentação. Os adultos e as instituições muitas vezes, deixam de fora o que seria capaz de articulá-los: a experiência com a cultura. Questões como alfabetizar ou não na Educação Infantil e a integração entre as etapas de ensino permanecem atuais.

Entender que crianças, jovens e adultos são sujeitos da história e da cultura, além de serem por elas produzidos, e considerar as milhões de crianças brasileiras de 0 a 5 anos como crianças e não só alunos, implica ver o pedagógico na sua dimensão cultural, como conhecimento, arte e vida, e não só como algo instrucional, que objetiva ensinar coisas. Essa reflexão vale para a Educação Infantil e o Ensino Fundamental. Aliás, eles são indissociáveis: ambos envolvem conhecimentos e afetos; saberes e valores; cuidados e atenção; seriedade e riso. O cuidado, a atenção, o acolhimento estão presentes na Educação Infantil; a alegria e a brincadeira também. $E$, nas práticas realizadas, as crianças aprendem.

Na Educação Infantil e no Ensino Fundamental, o objetivo é atuar com liberdade para assegurar a apropriação e o desenvolvimento do conhecimento por todos. O objetivo é garantir o acesso, de todos a vagas em creches e pré-escolas, assegurando o direito de brincar, criar e aprender. Nos dois tipos de ensino, há grandes desafios: o de pensar a creche, a pré-escola e a escola como instâncias de 
formação cultural; das crianças como sujeitos de cultura e história, sujeitos sociais.

A implantação da Lei n. ${ }^{\circ} 11.274$ (BRASIL, 2006), que estabeleceu o Ensino Fundamental de nove anos com ingresso de crianças de 6 anos de idade, teve por objetivos promover a melhoria da equidade e qualidade da Educação Básica; estruturar o Ensino Fundamental, garantindo-Ihe uma nova forma, e ainda um tempo maior para os alunos se apropriarem da alfabetização e do letramento (BRASIL, 2013).

Sabe-se que o cumprimento puro e simples da lei não garante que os objetivos almejados sejam atingidos, devendo-se considerar diversas condições para a efetivação de um trabalho de 54 qualidade, capaz de proporcionar a “[...] aquisição de conhecimento, respeitando a especificidade da infância nos aspectos físico, psicológico, intelectual, social e cognitivo" (PARANÁ, 2010, p. 9).

Como esclarece Nascimento (2006), é preciso pensar que as crianças têm modos próprios de conhecer o mundo e com ele interagir, cabendo aos professores viabilizar um ambiente no qual a infância possa ser plenamente vivida.

Dessa forma, destaca-se um pressuposto essencial apresentado pelas DCNEB:

Art. 29 A necessidade de assegurar aos alunos um percurso contínuo de aprendizagens torna imperativa a articulação de todas as etapas da educação, 
especialmente do Ensino Fundamental com a Educação Infantil, dos anos iniciais e dos anos finais no interior do Ensino Fundamental, bem como do Ensino Fundamental com o Ensino Médio, garantindo a qualidade da Educação Básica.

$\S 1 .^{\circ}$ O reconhecimento do que os alunos já aprenderam antes da sua entrada no Ensino Fundamental e a recuperação do caráter lúdico do ensino contribuirão para melhor qualificar a ação pedagógica junto às crianças, sobretudo nos anos iniciais dessa etapa da escolarização. (BRASIL, 2013, p. 136).

De acordo com essa premissa, acrescentase que, mais do que valorizar o que os alunos já aprenderam, certamente é preciso também concebê-los para além de alunos, como seres humanos e especificamente como crianças, sujeitos dotados de conhecimentos, saberes, emoções, personalidade e de uma subjetividade que lhes tornam únicos.

A ludicidade na ação pedagógica é uma ação imprescindível, uma vez que a criança tem suas necessidades supridas, o confronto com desafios e uma fonte de prazer, aprendizagem e desenvolvimento que não se encerra com o findar de um ciclo de ensino.

Desse modo, ressalta-se que 0 uso do brinquedo ou do jogo, com fins pedagógicos, tem grande relevância para os processos de ensino e aprendizagem e para o desenvolvimento infantil, 
motivo pelo qual, desde que seja mantida a ação intencional da criança na brincadeira, o educador pode com ela potencializar a aprendizagem, ou seja,

[...] significa transportar para o campo do ensino e aprendizagem condições para maximizar a construção do conhecimento, introduzindo as propriedades do lúdico, do prazer, da capacidade de iniciação e ação ativa e motivadora. (KISHIMOTO, 2001, p. 37).

Enfatiza-se que a continuidade entre as etapas de ensino consiste em uma problemática anterior à Lei n. ${ }^{\circ} 11.274$ (BRASIL, 2006), uma vez que a transição da Educação Infantil para o Ensino Fundamental já se defrontava com um rompimento abrupto, visto que, tradicionalmente, nas práticas escolares há um distanciamento entre ambas em seus modos e concepções, especialmente pela oposição entre o brincar, aceito na Educação Infantil, e o estudar, exigido no Ensino Fundamental. Embora a brincadeira seja associada à infância e às crianças, ela ainda é pouco valorizada, ao menos nas sociedades ocidentais ou, até mesmo, considerada irrelevante para a educação formal, sendo frequentemente concebida como oposta ao trabalho, tanto na escola, quanto na família (BORBA, 2006).

Segundo Neves, Gouvêa e Castanheira (2011), a transição entre a Educação Infantil e o Ensino Fundamental é um momento crucial na vida 
das crianças, sendo o diálogo importante para a compreensão dos entraves, rupturas e/ou continuidades vivenciadas pelas crianças nessa passagem de etapa escolar, visando alinhá-las para evitar que as crianças vivenciem tensão entre esses dois níveis de ensino. Assim se destaca que:

[...] Educação Infantil e ensino fundamental são indissociáveis; ambos envolvem conhecimentos e afetos; saberes e valores; cuidados e atenção; seriedade e riso. O cuidado, a atenção, o acolhimento estão presentes na Educação Infantil; a alegria e a brincadeira também. E, nas práticas realizadas, as crianças aprendem. Elas gostam de aprender. Na Educação Infantil e no ensino fundamental, o objetivo é atuar com liberdade para assegurar a apropriação e a construção do conhecimento por todos. Na Educação Infantil, o objetivo é garantir o acesso de todos que assim o desejarem, a vagas em creches e pré-escolas, assegurando o direito da criança brincar, criar, aprender. [...] Temos grandes desafios: o de pensar a creche, a pré-escola e a escola como instâncias de formação cultural; o de ver as crianças como sujeitos de cultura e história, sujeitos sociais. (KRAMER, 2006b, p.22).

O processo de transição da Educação Infantil para o Ensino Fundamental deve acontecer de modo que os segmentos se relacionem, desenvolvendo um processo unificado. Destaca- 
se a necessidade de considerar a importância da Educação Infantil na articulação entre seu último ano e o primeiro ano do Ensino Fundamental, cujo objetivo é a ininterrupção da aprendizagem e o desenvolvimento psíquico dos estudantes diante das mudanças vivenciadas pelos alunos. Reflete sobre a mudança de etapas da educação básica, abordando estratégias de acolhimento e adaptação tanto para as crianças quanto para os docentes. As ações são realizadas na escola, espaço preparado para a formação do homem, considerando-o como histórico social e cultural.

A antecipação da entrada da criança para o Ensino Fundamental está legitimada em leis como as Diretrizes Curriculares Nacionais da Educação 58 Básica, no artigo 11 das Diretrizes Curriculares da Educação Básica que traz orientações sobre o momento de transição:

Art. 11. Na transição para o Ensino Fundamental a proposta pedagógica deve prever formas para garantir a continuidade no processo de aprendizagem e desenvolvimento das crianças, respeitando as especificidades etárias, sem antecipação de conteúdos que serão trabalhados no Ensino Fundamental. (BRASIL, 2013, p. 100)

A passagem entre etapas demanda muita atenção dos envolvidos, havendo um equilíbrio entre as mudanças vivenciadas e garantindo 
a integração e continuidade dos processos de aprendizagens das crianças.

O $1^{\circ}$ ano é uma transição entre a Educação Infantil e o ensino fundamental, onde é necessário assegurar o direito à infância e um trabalho pedagógico que envolva experiências em diferentes linguagens e suas expressões, buscando uma metodologia que favoreça o desenvolvimento social, afetivo e cognitivo dessas crianças. (Currículo Comum - p. 260)

É possível visualizar a dificuldade encontrada por professores, coordenadores e gestores para viabilizar uma transição inclusiva entre a Educação Infantil e o Ensino Fundamental. Para a formação integral da criança, torna-se necessária a reorganização em diversos níveis, possibilitando a articulação e a ressignificação dos espaços escolares e o redimensionamento do tempo pedagógico.

Educação Infantil e Ensino Fundamental são os períodos que compõem uma mesma fase de desenvolvimento do psiquismo. Nesse período a criança adquire consciência das expectativas e demandas associadas ao papel de aluno e das habilidades necessárias para atendê-las, na medida em que participa das atividades escolares e estabelece interações com o professor e outras crianças no novo contexto. Assim, ela muda sua forma de existência, situa-se numa nova posição 
social, marcando o início de um novo período na sua vida, se desenvolve e apropria-se de conhecimentos teóricos.

A atividade dominante no período de desenvolvimento dos anos finais da Educação Infantil é caracterizada pelos como os jogos de papéis, modelada pelas relações sociais. São atividades lúdicas que promovem a necessidade de agir com os objetos, desenvolve ações cujo motivo está no próprio processo do fazer. Para Elkonin (1960a), no jogo de papéis se efetua a transição do pensamento objetivo/concreto a outras formas mais abstratas. Vale também destacar o desenvolvimento da capacidade de generalização do pensamento infantil que tem lugar na atividade de jogo.

60 A transição entre etapas não acontece somente na mudança de espaço, mas também no seu psiquismo, meio social e cultural. Mukhina (1996) considera, nessa direção, que o jogo é o principal fator para introduzir a criança no "mundo das ideias": a ação da criança passa a ser determinada pelas ideias, não mais pelos objetos, o que representa uma grande mudança na relação da criança com o entorno.

Pasqualini (2014) ressalta que:

Para que o jogo de papéis se constitua de fato em fonte de desenvolvimento psíquico, ou seja, fonte para a formação do novo no psiquismo infantil, é preciso criar condições para que seu conteúdo desafie as capacidades 
já formadas na criança (desenvolvimento real) e mobilize funções psíquicas que estão iniciando seu desenvolvimento (desenvolvimento iminente). Portanto, uma das importantes tarefas da escola de Educação Infantil refere-se à ampliação do conhecimento de mundo da criança (ELKONIN, 1960a, p. 493-503)

Por meio das capacidades é formado e desenvolvido nas crianças, o caráter produtivo voltado para capacidade de planejamento da ação, e com a mediação do adulto, transforma seus conhecimentos espontâneos ou empíricos em conhecimentos científicos.

O processo de transição da Educação Infantil para o Ensino Fundamental há um tempo é foco de estudo, e a BNCC, documento oficial mais atualizado, também direciona um olhar para este movimento. Ela declara que é preciso garantir integração e continuidade dos processos de aprendizagens das crianças, respeitando as suas singularidades e as diferentes relações que estabelecem com os conhecimentos, assim como a natureza das mediações de cada etapa e a necessidade de estratégias de acolhimento e adaptação, tanto para as crianças quanto para os professores, de modo que a nova etapa se construa com base no que a criança sabe e é capaz de fazer em uma perspectiva de continuidade de seu percurso educativo.

Para que as crianças vençam os desafios da transição, é indispensável a estabilidade 
entre as mudanças vividas, a continuidade da aprendizagem e o acolhimento afetivo. Assim, acontecerá a integração entre os níveis de escolaridade, articulando os conhecimentos já apropriados a novos saberes.

É importante garantir à criança a compreensão de seu próprio agir e da interação com o outro, no envolvimento em situações favoráveis que lhe permitam o desenvolvimento afetivo, motor, social, cognitivo e moral. Isso deve ocorrer mediante à flexibilização de rotinas, metodologias e das propostas curriculares de forma que se tornem acessíveis buscando uma prática inclusiva.

É preciso permitir um olhar reflexivo sobre o diagnóstico real dessas crianças para pensar, 62 adaptare promover práticas efetivasqueminimizem diferenças entre essas etapas de escolaridade.

Esse distanciamento deve ser considerado um ponto de partida para a elaboração de propostas pedagógicas que contemplem as necessidades das crianças nessa etapa de escolarização, a fim de se aproveitar o potencial das diferenças, evitando uma ruptura de práticas e valores que segregam.

\section{Considerações Finais}

Dadas as rupturas e incoerências que em muitas vezes, vem delimitando a infância da criança, seus desejos, suas necessidades e singularidades, o exposto nos permite refletir a articulação entre as duas etapas da educação básica (Educação Infantil e Ensino Fundamental), assumindo uma transição 
sem rupturas, respeitando a particularidade do movimento, de maneira natural, com mediação dos profissionais envolvidos, evidenciando como imprescindível, o compromisso efetivo com o desenvolvimento da criança.

Mesmo com um processo histórico do período de aprendizagem das crianças e as políticas públicas que delimitam as ações do que será trabalhado com elas, é importante defender o currículo pautado na Pedagogia Histórico-Crítica, considerando no homem seu conhecimento produzido de forma histórica, cultural e social. A BNCC chega como um currículo nacional, mas que deve ser adequada de acordo com a vivência, com o meio que está inserida, promovendo o conhecimento historicamente apropriado.

No processo de transição, é importante refletir sobre a necessidade de mudanças significativas no processo de aprendizagem do primeiro ano do ensino fundamental, e que as crianças se apropriem de seu novo ambiente sem perderem o momento de explorar o universo infantil que nele existe. Os docentes, em sua organização pedagógica devem compreender, ouvir e considerar as crianças em suas especificidades, valorizar o lúdico, as manifestações culturais infantis, o currículo e os espaços de aprendizagem, desenvolvendo nelas a autonomia, a liberdade e a vontade em aprender sempre mais.

Sendo assim, torna-se um desafio a articulação entre a Educação Infantil e os anos iniciais do ensino 
fundamental também na formação do docente, no que tange a formação inicial e continuada afim de que o profissional possa ampliar o pensamento teórico da criança, a neoformação da idade escolar, considerando a particularidade de cada uma delas, respeitando seusinteresses, motivos e necessidades.

\section{REFERÊNCIAS}

BRASIL. Diretrizes Curriculares Nacionais da Educação Básica. Brasília, DF: MEC, 2013. Disponível em:http://portal.mec.gov.br/index.php?option=com_ docman\&view=download\&alias $=13448$-diretrizescuriculares-nacionais-2013-pdf\&Itemid=30192. Acesso em: 25 jun 2021.

Ministério da Educação. Secretaria de 64 Educação Básica. Diretrizes Curriculares Nacionais para a Educação Infantil. Brasília: MEC, SEB, 2010.

Ministério da Educação. Base Nacional Comum Curricular. Brasília: MEC, 2017. Disponível em: http://basenacionalcomum.mec.gov.br. Acesso em: 25 jul. 2021.

BRASIL. MEC. Ensino Fundamental de Nove Anos: orientações para a inclusão da criança de seis anos de idade. Brasília, 2006

BORBA, A. M. O brincar como um modo de ser e estar no mundo. In: BRASIL. Ministério da Educação. Secretaria de Educação Básica. Ensino Fundamental de nove anos: orientações para a inclusão da criança de seis anos de idade. 2. ed. Brasília, DF: MEC, 2007. p. 35-47.

FUSCO, J. Aprendizagem cooperativa: práticas inclusivas da Educação Infantil ao Ensino Fundamental. Dissertação em Docência da Educação 
Básica -UNESP Faculdade de Ciências, Universidade Júlio de Mesquita. São Paulo, p. 25 e 26. 2017.

ELKONIN, D. B. Característica general del desarrollo psíquico de los niños. In: SMIRNOV, A. A. et al. (Orgs.). Psicología. México: Grijalbo, 1960a, p. 493-503.

KISHIMOTO, T. M. Jogo, brinquedo, brincadeira e a educação. 5. ed. São Paulo: Cortez, 2001.

KRAMER, S. A infância e sua singularidade. In: BRASIL. Ministério da Educação. Ensino fundamental de nove anos: orientações para a inclusão da criança de 6 anos de idade. Brasília, 2006a. p. 19-21.

MUKHINA, V. Psicologia da idade pré-escolar. São Paulo: Martins Fontes, 1996

NEVES, V. F. A.; GOUVÊA, M. C. S.; CASTANHEIRA, M. L. A passagem da educação infantil para o ensino fundamental: tensões contemporâneas. Educação e Pesquisa, São Paulo, v. 37, n. 1, p. 121-140, jan./abr. 2011.

PARANÁ. Secretaria do Estado da Educação. Ensino

Fundamental de nove anos: orientações pedagógicas para os anos iniciais. 22. ed. Curitiba, 2010.

PASQUALINI, J. C. Contribuição ao debate sobre - problema da preparação para a escola de Ensino Fundamental na Educação Infantil. Bauru, SP: Unesp, 2014. Disponível em: http://periodicos.uem.br/ojs/ index.php/TeorPratEduc/article/view/28211/pdf_72. Acesso em 21 de jun de 2021. 


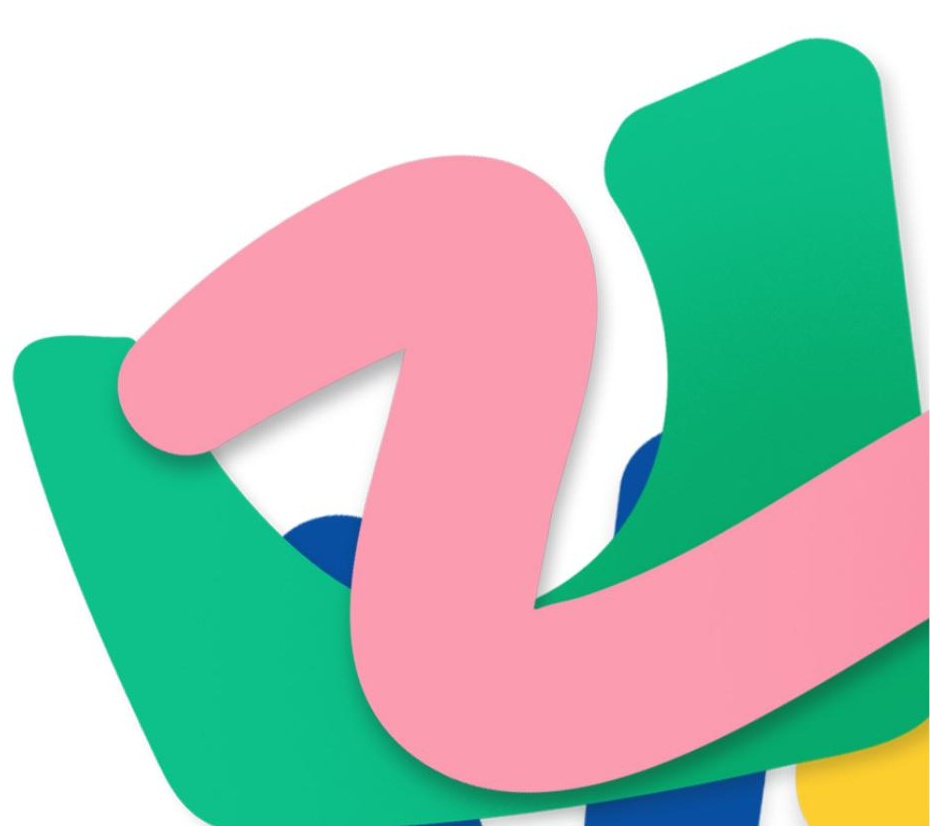




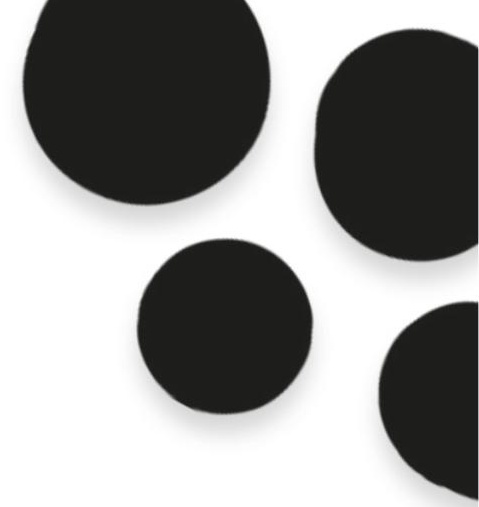




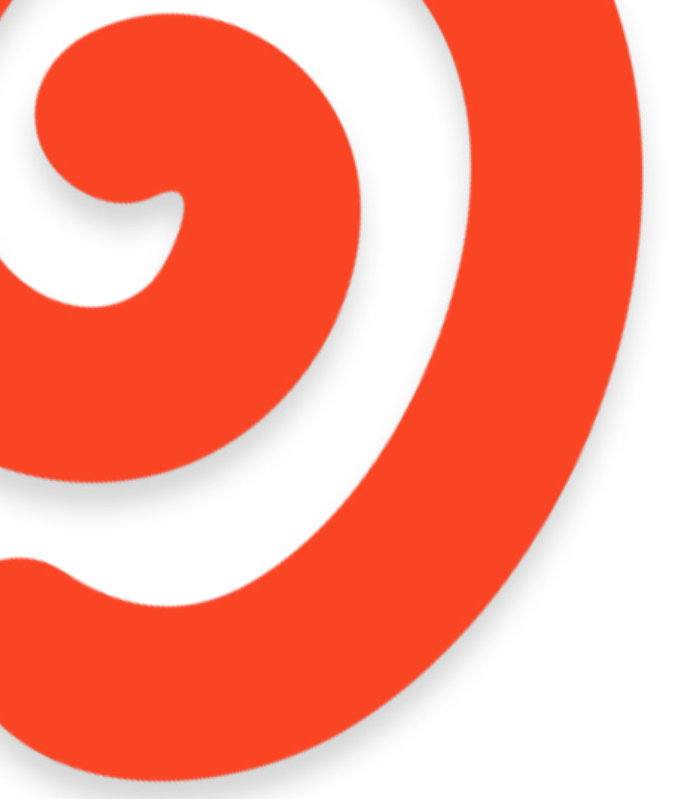




\section{A RELAÇÃO ESCOLA E FAMÍLIA NA ESCOLARIZAÇÃO DAS CRIANÇAS EM PERÍODO DE PANDEMIA: DESAFIOS DO ENSINO REMOTO}

Bruna Di Richelle Souza Padovini Simone Aparecida Ferreira Xavier Tuler

\section{INTRODUÇÃO}

A relação escola e família no processo de escolarização das crianças em período de Pandemia: Desafios do Ensino Remoto é um relato de experiência ocorrido no ano de 2020 frente aos desafios do ensino remoto enfrentados pela Escola de Educação Infantil Creche Sementinhas. A escola está localizada no município de Bauru, interior do Estado de São Paulo, e atende 92 crianças de creche e pré-escola, com faixa etária entre 1 a 5 anos. A Creche Sementinhas é uma Organização da Sociedade Civil (OSC), de inciativa filantrópica e sem fins lucrativos, gerenciada por uma diretoria legalmente constituída e conveniada com a Prefeitura Municipal de Bauru, por meio de um Termo de Colaboração renovado anualmente. Fundada em 2013 a Creche Sementinhas, teve sua abertura em 2017 atendendo 60 crianças da região. Atualmente, mais de 100 famílias aguardam por uma vaga na escola comprovando a demanda e a importância de uma escola de Educação Infantil nesse local. 
A Instituição Escolar sempre investiu na parceria entre escola e família como uma prática que visa o favorecimento do processo escolar das crianças, principalmente por atuar na primeira infância. Sendo assim, o presente capítulo tem por objetivo apresentar como esta relação desenvolveu-se em período de pandemia - Covid-19 e os desafios do ensino remoto. Os objetivos específicos são: apresentar a importância da relação escola e família como prática que favorece o processo de escolarização da criança e discorrer sobre as possibilidades de parceria estabelecida com a família durante o ensino remoto.

Almeja-se que as contribuições desse relato possam colaborar com a prática docente e gestora 70 das instituições de educação infantil, visando favorecer e fortalecer a relação escola e família, sobretudo em período de pandemia, superando os desafios e as implicações deste período.

Escola e família têm cada um o seu papel no desenvolvimento dessa relação, com pressupostos teóricos fundamentados em VYGOTSKY, 2001; WALLON, 2007; BRONFFENBRENNER, 1996 e 2011 e BERGER E LUKMANN 2011 foram desenvolvidos os temas sobre a importância da família na socialização e desenvolvimento do indivíduo para a sociedade e as atividades e estratégias pedagógicas na Proposta Pedagógica de Bauru (BAURU, 2016). 


\section{A Relação Escola e Família}

Muitos estudos acerca do desenvolvimento humano (VYGOTSKY, 2001; WALLON, 2007; BRONFFENBRENNER, 1996 e 2011), afirmam a importância do papel da família na socialização primária das crianças, sendo este o primeiro grupo de referências na formação e desenvolvimento social, cognitivo e emocional dos indivíduos.

Por meio de ações afetivas de cuidado e de proteção, o adulto responsável pela criança, possibilita importantes significações que servirão como mediadores à organização do pensamento e do seu desenvolvimento integral.

À luz da teoria do desenvolvimento humano de Urie Bronffenbrenner (1996 e 2011) considera-se o sujeito dentro de seu contexto social, atentandose as inúmeras influências e relações vivenciadas por ele desde o seu nascimento ao longo de sua vida. Nesta perspectiva, torna-se fundamental considerar os aspectos biológicos, emocionais, sociais e culturais pelos quais o sujeito vivencia.

Desta forma, o principal contexto de desenvolvimento é a família, sendo a primeira instituição social em que a criança tem contato e a partir dela, estabelece as suas primeiras relações com o mundo.

Em conformidade com os estudos de Prado (1991) "é através da família em que a criança tem acesso ao mundo adulto, e nesta relação ela desenvolve a sua identidade." Sendo assim, a família exerce a importante função de ensinar 
sobre a cultura, os costumes e os valores característicos desta instituição:

Ora, toda família visa, primeiramente, reproduzir-se a si próprio em todos os sentidos: seus hábitos, costumes e valores que transmitirão por sua vez às novas gerações. É na família ainda que a criança recebe orientação e estímulo para ocupar um determinado lugar na sociedade adulta, em função de seu sexo, sua raça, suas crenças religiosas, seu status econômico e social. (PRADO, 1991, p.40).

Esta instituição, por sua vez, sofre a intervenção de outros diferentes contextos da sociedade. Sendo assim, as ações que ocorrem em outras instituições socializadoras como escolas, trabalhos, igrejas etc, podem contribuir e influenciar o desenvolvimento dossujeitosinseridosnestarelação. Aexemplo desse conceito proposto na teoria de Bronfenbrenner (2011), a criança que frequenta a educação infantil está inserida no contexto familiar e no contexto escolar. As ações que ocorrem nestas diferentes instituições, influenciam o desenvolvimento desta mesma criança.

A escola exerce um papel diferente da família: as escolas têm a função de transmitir conhecimentos do patrimônio cultural da sociedade, tornandose um ambiente formal para a construção de diferentes aprendizagens, com intencionalidade e especificidades diferentes da família. 
Sendo assim, as escolas pautam-se em princípios científicos, na transmissão e produção do saber e as famílias são responsáveis pela formação de valores e princípios morais, afetivos e éticos, norteados pelos inúmeros fatores como: econômicos, culturais, religiosos, regionais. De acordo com Saviani (2012) "a escola é uma instituição cujo papel consiste na socialização do saber sistematizado".

Nesta mesma perspectiva, é importante reconhecer a importância do trabalho desenvolvido na educação infantil. Apesar da atuação ocorrer em alunos com pouca idade, sabe-se que as crianças são seres históricos-sociais, produtoras de cultura, cabendo ao professor reconhecer tais especificidades para então atuar visando avançar e promover o desenvolvimento científico, artístico, ético e cultural dos seus alunos. (ARCE e MARTINS, 2010).

Sendo assim, apesar de família e escola exercerem papéis diferentes, elas são fundamentais na formação do indivíduo. São instituições socializadoras diferentes (socialização primária e socialização secundária), mas que juntas, podem promover o máximo das possibilidades de desenvolvimento deste indivíduo. (BERGER E LUKMANN 2011).

Refletir sobre como essa relação interfere e colabora para o desenvolvimento dessa criança, principalmente em tempos de Pandemia - Covid 19, em que as aulas foram prioritariamente remotas, evidencia a importância e a necessidade que esta relação deve ser de parceria, colaboração, 
companheirismo, afeto e compreensão, sobretudo na educação infantil.

Diante de tais estudos, considera-se fundamental o desenvolvimento de uma parceria favorável entre escola e família na promoção do processo de escolarização dos alunos, sobretudo das crianças de primeira infância. O estabelecimento de uma harmoniosa parceria entre estas instituições pode colaborar não apenas para o desempenho escolar do aluno, mas para as dimensões globais de seu desenvolvimento.

Escola e Família em Contexto de Pandemia - Relato.

Fundamentada nesses ideais, a escola de Educação Infantil Creche Sementinhas, já investia 74 em ações e práticas que favorecessem uma parceria entre escola e família, visando beneficiar - processo de escolarização das crianças. Entretanto, em março/2020, um novo contexto surge com os enfrentamentos da Pandemia (Covid-19) trazendo a necessidade de repensar as práticas pedagógicas e tornando o papel da família, ainda mais essencial no processo de escolarização dos alunos.

Diante dos riscos à saúde pelo novo coronavírus (covid-19), recomendou-se o ensino remoto para todos os alunos. Esse foi um grande desafio para as escolas e as famílias. As práticas de ensino deveriam ser repensadas e a partir de então, as aulas chegariam para as famílias de maneira remota, ou seja, todo conteúdo planejado e produzido, deveria 
ser transmitido e disponibilizado de maneira online para alunos e familiares.

Enquanto Instituição de Educação Infantil, o desafio tornou-se maior ainda: era necessário pensar em aulas que fossem planejadas com intencionalidade educacional, aproveitando as máximas possibilidades dentro do contexto do lar. Outras implicações como o acesso à internet e aos meios digitais, além da mobilização do adulto responsável pela criança também foram consideradas.

Para o estabelecimento do ensino remoto, a equipe da escola precisou refletir e avaliar quais as ferramentas digitais seriam utilizadas para constituir um canal de comunicação efetivo com as famílias, e quais as melhores estratégias de ensino seriam eleitas para dar continuidade ao ano letivo mesmo à distância.

Muitas mudanças realizadas na escola foram necessárias para acompanhar essa nova modalidade de ensino. Aquisições em tecnologias e capacitação de equipe precisaram ser efetivadas para que o ensino pudesse continuar sendo oferecido com qualidade e intencionalidade nas diferentes linguagens de aprendizagem dos alunos.

Neste novo período, os familiares tornaramse a "ponte" necessária para conectar alunos e professores e viabilizar o ensino à criança. Nesta nova modalidade, as aulas seriam planejadas da maneira que a família pudesse organizar o ensino e os espaços para que a apropriação dos conhecimentos pudesse ocorrer. 
Os desafios eram grandes: dentro do ambiente doméstico, crianças e familiares possuem rotinas diferentes as da escola; o adulto responsável estaria sobrecarregado com as multifunções da casa e do trabalho e dificuldade no acesso aos materiais e recursos para o desenvolvimento das aulas.

Todas essas questões precisaram ser consideradas para o desenvolvimento das ações e para o estabelecimento do objetivo principal da escola para esse período pandêmico: dar continuidade ao vínculo escolar com a criança.

$\mathrm{O}$ ano letivo precisava ser cumprido, seguindo todas as legislações no campo da educação. Desta forma, tornou-se necessário planejar práticas e estratégias que pudessem acolher às famílias 76 dos alunos, para além do ensino proposto nas atividades para casa.

Compreendeu-se, portanto, que a criança pequena precisa de amor e da atenção do adulto que está a sua volta, relacionando-se favoravelmente com ela. O objetivo da instituição então foi desenvolver estratégias que fortalecessem esse vínculo entre crianças e familiares e buscassem promover e resgatar práticas afetivas entre pais e filhos!

Para a execução desse objetivo, realizou-se um planejamento intencional pautado em algumas práticas que serão apresentadas a seguir:

Contato com as Famílias - A Importância Da Comunicação. A equipe escolar realizou contato telefônico com os familiares de cada aluno da escola investigando 
quais eram os canais de acessibilidade sendo eles: e-mails ou plataformas digitais como as redes sociais do Facebook, Instagram e Grupos de WhatsApp. Além disso, a equipe disponibilizou auxílio e recursos pedagógicos para as famílias nesse período de isolamento. De acordo com o levantamento realizado, aderiu-se à formação de um grupo de pais pela rede social do WhatsApp, tendo em vista, que alguns pais não tinham mais acesso à e-mails, ou não possuíam conta no Facebook.

Os grupos de pais foram formados e o contato entre escola e família passou a ser realizado constantemente por meio do envio das videoaulas, roteiro de aulas e informações sobre esta nova organização do ensino (retirada de materiais na escola, impressões e demais orientações necessárias para esse período). Na abertura dos grupos, a equipe pedagógica disponibilizou uma importante reflexão sobre como esta ferramenta (WhatsApp) poderia ser utilizada beneficamente para o desenvolvimento do ensino das crianças, foram apresentados as possibilidades e os limites necessários para obomandamento egerenciamento das informações. Este canal tornou-se a ferramenta de maior importância para o desenvolvimento das atividades neste período de ensino remoto.

As devolutivas dos familiares também ocorreram por essa plataforma, proporcionando à escola um vasto e rico material de registro deste envolvimento familiar com o processo de ensino dos alunos no 


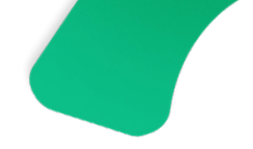

período de pandemia. A escola criou uma política de valorização dos familiares por meio de agradecimento contínuo e organização destas produções.

Outro espaço para a comunicação com a família foram as reuniões on-line, ocorridas pela plataforma do Google Meet e Zoom (esta foi adquirida pela instituição com a finalidade de facilitar os encontros entre alunos e professores e as reuniões de pais). As reuniões seguiram com pautas, vídeos e apresentação do trabalho pedagógico.

Apesar do distanciamento social imposto pela pandemia (Covid-19), a escola esteve atenta às novas formas de comunicação para manter o bom andamento da parceira escola e família, tendo em vista a atuação na educação infantil.

Figuras 1 e 2: Relatos da família após reunião de Pais.

\begin{tabular}{|c|c|}
\hline Benjamin - INF 2 (Măe) & \\
\hline $\begin{array}{l}\text { Eu e minha familia somos } \\
\text { imensamente gratos pelo privilégio } \\
\text { de poder ter participado de um } \\
\text { ensino de qualidade e com muito } \\
\text { amor para com meu filho e todas as } \\
\text { crianças. } \\
\text { Desafios vieram e nenhuma desistiu }\end{array}$ & $\begin{array}{l}\text { Arthur Cardoso - INF } 2 \\
\text { Foi um ano atipico e incrivel. Muito } \\
\text { bom poder contar com vocês. } \\
\text { Sempre muito dispostas a ajudar, } \\
\text { distante mas sempre muito perto. } \\
\text { Sou suspeita a falar mas amo muito } \\
\text { vocês. Gratidāo gratidāo mesmo. } \\
\text { Ė que ano de } 2021 \text { seja melhor pra } \\
\text { todos nós }\end{array}$ \\
\hline $\begin{array}{l}\text { Desafios vieram e nenhuma desistiu } \\
\text { continuaram firmes e rompendo } \\
\text { barreiras para que o propósito de } \\
\text { ensino fosse entregue. } \\
\text { Agradeço de coração. } \\
\text { A cada uma, direção, coordenação, } \\
\text { professoras, tias, estagiárias. Que }\end{array}$ & 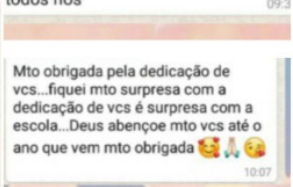 \\
\hline $\begin{array}{l}\text { Deus retribua muito mais na vida de } \\
\text { vocês. }\end{array}$ & intil 3 (Novo) \\
\hline $\begin{array}{l}\text { Salmos } 126-5 \\
\text { Que aqueles que semeiam chorando } \\
\text { façam a colheita com alegria! } \\
6 \text { Aqueles que sairam chorando, } \\
\text { levando a semente para semear, }\end{array}$ & \\
\hline $\begin{array}{l}\text { voltarão cantando, cheios de } \\
\text { alegria,trazendo nos braços os feixes } \\
\text { da colheita. }\end{array}$ & $\begin{array}{l}\text { Mariah infantill } 3 \text { (Novo) } \\
\text { obrigada a todos pela dedicaçấo um } \\
\text { feliz natal e um ano novo de grandes }\end{array}$ \\
\hline da colheita. & realizaçōes para todos nos ㅃi! 10.10 \\
\hline
\end{tabular}




Heitor - INF 2
Gratidão por 2020 ter nos ensinado
tanto, obrigada Equipe Sementinhas
pela parceria e dedicaçăo nesse
periodo dificil e de aprendizado para
todos nós. Que Deus abençб̋e a
todos, um Natal lluminado e um ano
novo repleto de saude para todos.
um abraço, Heitor e Familia

Mank - INF 4

Bom dial

Quero agradecer a coordenadora Bruna e as Professoras e auxiliares do infantil iV em especial, porque neste ano tăo dificil e distante vocés inovaram e nlo perderam o contato com nossas crianças.

Casa evento trouxe muita felicidade à minha filha e isso so agradeço.

Ele fala de vocès e dos amigos todos os dias e estou muito feliz dela estar matriculada na creche.

Um abraço apertado em cada uma de ves e todos da equipe.

A mostra de artes foi linda!
Arthur Rodriques - INF 4

Bom dia equipe maravilhosa, eu fico deslumbrada com tanto carinho com as crianças, muito amor e carinho e é muito reciprocol Pq as crianças amam vcs, que Deus ilumine todos! O Arthur está com muitas saudades! Quer todos os dias ir pra creche, desejo um 2021 iluminado e cheio d. bençăos e realizaçбes pra todos vics L $4 h d$

\section{Bernardo - inF 2}

Obrigada, meninas e toda familia Sementinhas. Somos gratos a Deus pela vida de cada uma de vcs. Toda dedicaçăo em cada atividade proposta e amor pelas nossas crianças foi nitido neste ano. Quero aqui pedir desculpas por năo ter correspondido a todo

esse empenho dispensado a nos e agradecer mais uma vez pela compreensdo. 0 carinho que nossa familia recebeu de TODAS vcs foi incrivel, senti o abraço e o conforto mesmo de longe. E⿺

Que 2021 seja um ano de muita saude pra todos.

As Atividades Remotas e as Redes Sociais da Escola.

Concomitantemente com os grupos de pais, a instituição empenhou-se em desenvolver materiais para as outras redes sociais da escola: Plataformas do Facebook e Instagram, com o intuito de valorizar as atividades remotas realizadas em casa com os familiares. Outras informações marcaram estas redes sociais como: sugestões de brincadeiras, vídeos das educadoras com mensagens de carinho, afeto e saudades, possibilidades de experiências divertidas, culinárias, contação de histórias, músicas, material de apoio e incentivo aos pais de como organizar a rotina de estudos em casa com as crianças entre outras sugestões. 
As postagens nestas redes sociais foram estratégias criadas para incentivar a participação dos pais e valorizar o importante papel que eles exercem no desenvolvimento de seus filhos, aproveitando as ricas possibilidades de aprendizagem no próprio ambiente doméstico, sobretudo nas relações afetivas. Estas atividades realizadas em casa foram organizadas em vídeos e postadas semanalmente nas redes sociais.

As famílias também receberam vídeos com conteúdo de apoio às aulas elaborados pela equipe pedagógica e desenvolvidos de acordo com os temas trabalhados durante a semana de estudos. Essas gravações foram realizadas na creche com o intuito de aproximar o aluno da rotina escolar. 80 Iniciou-se, a partir de então, um Projeto por meio da Plataforma do Facebook com contações de histórias narradas pela própria equipe pedagógica. O Projeto denominado: "A hora da história", trouxe apresentações das obras de Vicent van Gogh, Ziraldo, Atividades Circenses, Livro das emoções entre outros. Outros materiais foram desenvolvidos pela equipe, tais como: Especial sobre Educação para o Trânsito, Técnicas de pinturas, Brinquedos com sucata, Experiências com os Fenômenos da Natureza, Encontrão Virtual de 7 de setembro, são exemplos de conteúdos produzidos pela equipe pedagógica durante este período.

A produção destes materiais para as redes sociais também possibilitou a interação com a comunidade 
escolar e demais interessados no projeto, bem como os parceiros e mantenedores da instituição que tem acesso às redes sociais da escola.

Com o intuito ainda, de envolver os adultos responsáveis pelos estudos das crianças (considerando que para que as aulas pudessem chegar ao aluno, era necessário o envolvimento da família), a equipe docente desenvolveu um planejamento de aulas que acolhessem o universo doméstico, tais como: resgatar brincadeiras antigas em família como amarelinha, petecas de sacola de plástico, cabra-cega ou promover culinárias simples como a receita de uma sopa, de um bolo, ou massinha caseira, desenhar com giz no chão, desenhar com os dedinhos em tinta ou até mesmo com os gravetos na areia, construir brinquedos com recicláveis, montar figuras com sucatas, brincar com caixas de papelão, com água no balde, com cobertas nas cadeiras para as divertidas cabanas e até pareamento das meias dos membros da casa, jogos boliche com embalagens, tinta com gelo, construção de instrumentos musicais com panelas e utensílios da cozinha e tantas outras possibilidades que envolvem o universo infantil e estão disponíveis no ambiente doméstico.

As aulas tinham uma intencionalidade pedagógica, mas tornaram-se possíveis de serem desenvolvidas em casa. Para as atividades mais específicas, foi elaborado um Kit de materiais contendo lápis, canetinhas, giz de cera, de lousa, folhas, tintas, 
carvão, colas, massinhas e demais materiais necessários para o desenvolvimento das propostas.

Figuras 3 e 4: Atividades das crianças em casa.
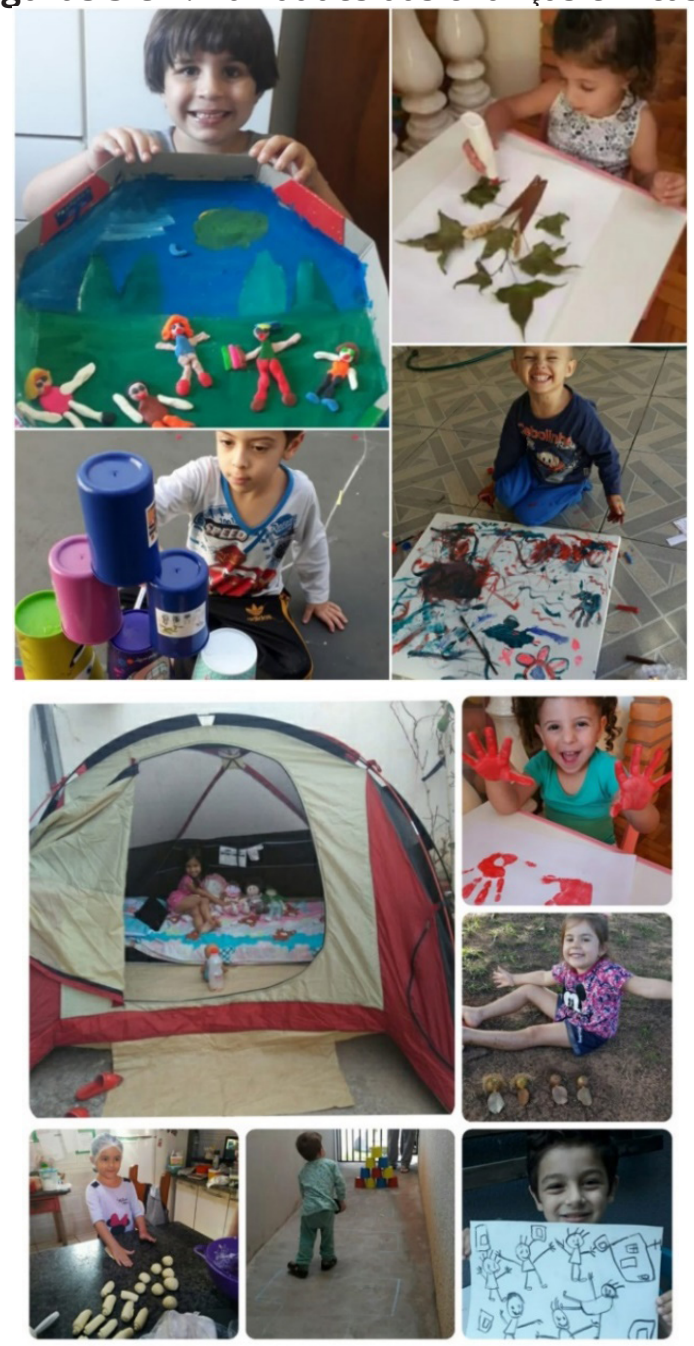

Fonte: arquivo pessoal 
Figuras 5 e 6: Atividades Ensino Remoto.
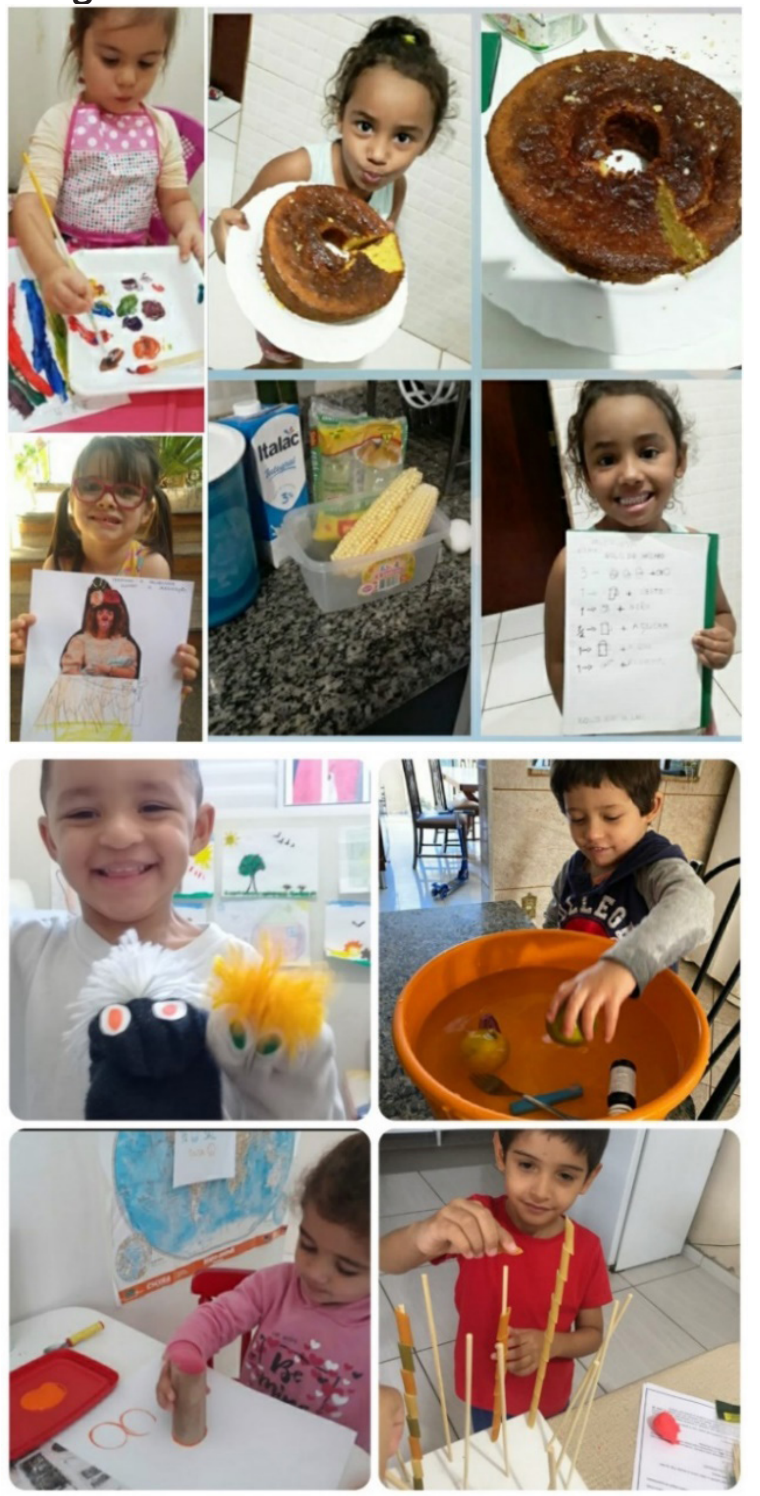

Fonte: Arquivo pessoal 
Figura 7: Atividades Ensino Remoto.

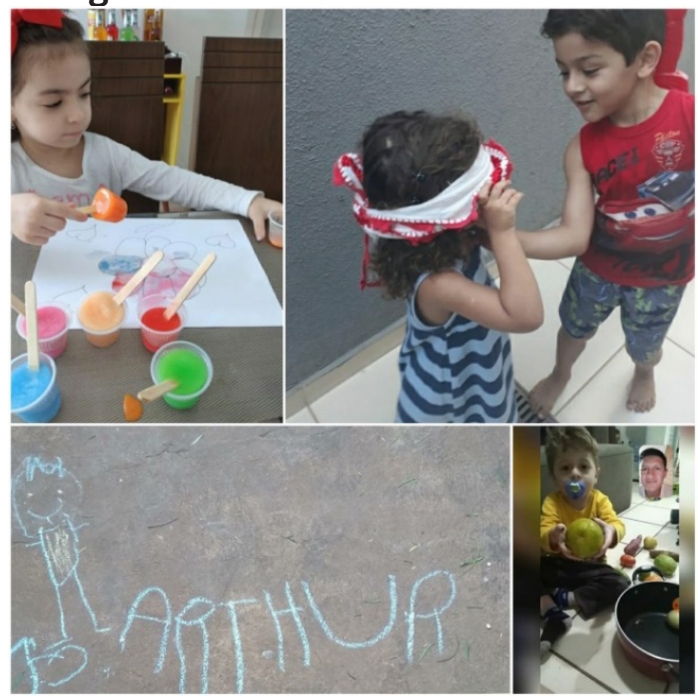

Fonte: Arquivo pessoal

Figura 8: Produção de materiais para as redes sociais.

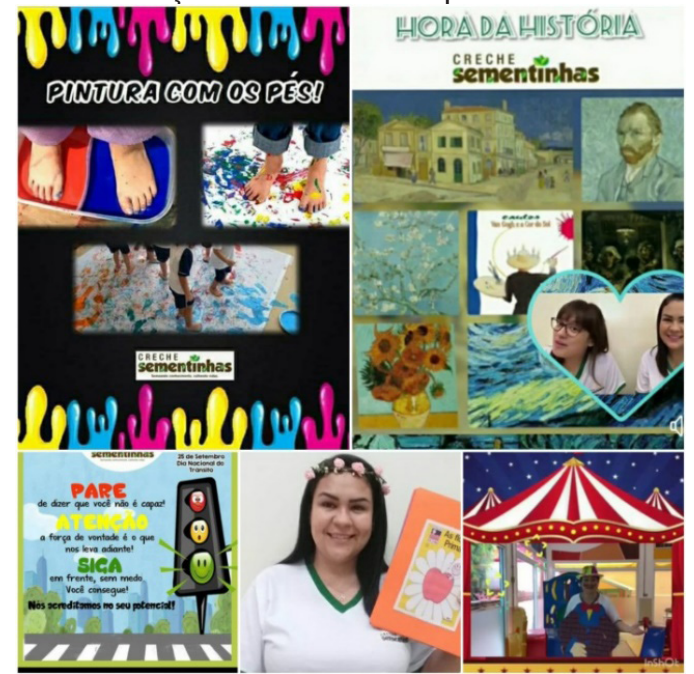

Fonte: Arquivo pessoal 


\section{Estratégias de Envolvimento dos Familiares.}

Em contrapartida às aulas para as crianças, pensou-se no suporte necessário aos adultos. As ligações da escola para as famílias prosseguiram periodicamente para oferecer ajuda às possíveis dificuldades com as crianças em casa. Buscou-se colaborar com o apoio assistencial às necessidades das famílias, viabilizando doações de alimentos da merenda escolar (política adotada para todas as escolas municipais e conveniadas de Bauru) e de cestas básicas do Projeto CoronaVIDA.

Em parceira com demais voluntários, a Creche Sementinhas confeccionou e distribuiu Kits de Higiene (álcool em gel, sabonete, pasta de dente, desinfetante, águasanitária, máscaraseinformativos sobre a Covid-19) para todas as famílias dos alunos e moradores em torno da escola.

Oportunizou-se ainda um Programa de Acompanhamento das Famílias, com o intuito de uma melhor aproximação com os familiares e consequentemente com o aluno, como mais um canal de comunicação entre escola e família.

Outras estratégias foram desenvolvidas como forma de estreitamento dessa relação: Kit de Artes para produção de uma Tela com as mães; Produção de Cartinhas aos profissionais da saúde (as crianças receberam um vídeo de uma mãe de aluno da escola que atua na enfermagem de um Hospital Público de Bauru, referência para o tratamento à Covid-19, junto com sua equipe 
explicando a rotina dos trabalhos); Drive-in Caça ao Tesouro com a participação dos pais; Pit Stop da Saudade à Fantasia (em comemoração à semana da criança); Quadro: "Dicas da Tia Creusa”, contendo dicas de culinária sugeridas pela cozinheira da escola e realizada por uma família - os alunos foram convidados a reproduzirem semanalmente as receitas; Quadro: "Sextou com a Tia Laine" com dicas de organização da casa e dos brinquedos, sugeridos pela colaboradora da instituição entre outras formas de conectar-se com a comunidade escolar para além das redes sociais.

Com a participação e envolvimento dos familiares nas propostas desenvolvidas, houve um resultado favorável na produção e nos registros das atividades 86 envolvendo a riqueza e as muitas possibilidades de aprendizagens dentro do universo doméstico.

Com a devolutiva das produções realizadas em casa e como mais uma estratégia de valorização da família no processo de escolarização das crianças, a equipe escolar organizou a $1^{\text {a }}$ Mostra de Artes: "Conhecimento, Arte e Cultura" em que os trabalhos realizados durante o ano, ocorridos remotamente, foram apresentados para toda a comunidade escolar durante uma semana de exposição. As visitas foram agendadas e organizadas por horário. Os participantes da mostra tiveram a oportunidade de apreciar a riqueza das produções. Ao término da vista, os alunos carimbaram as mãozinhas em Telas, deixando mais um registro especial na escola. 
Figura 9: Drive Caça ao Tesouro e Pit Stop da Saudade

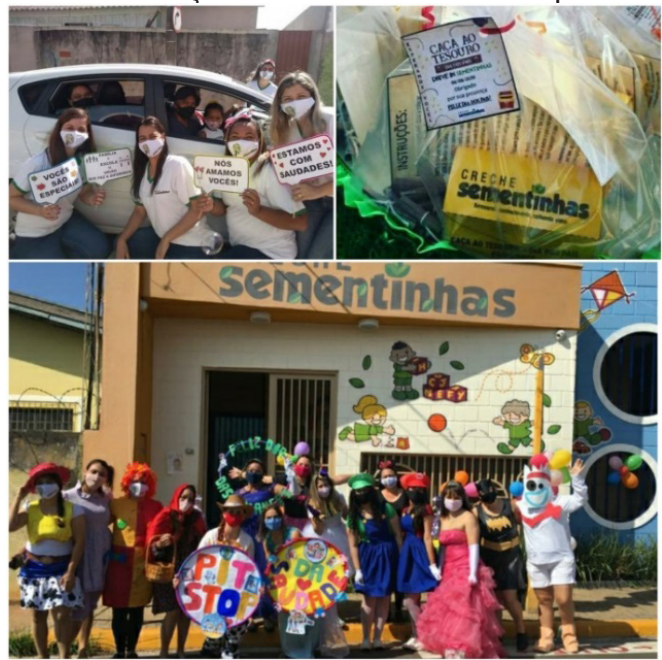

Fonte: arquivo pessoal

Figura 10: Dicas de Culinária e Organização

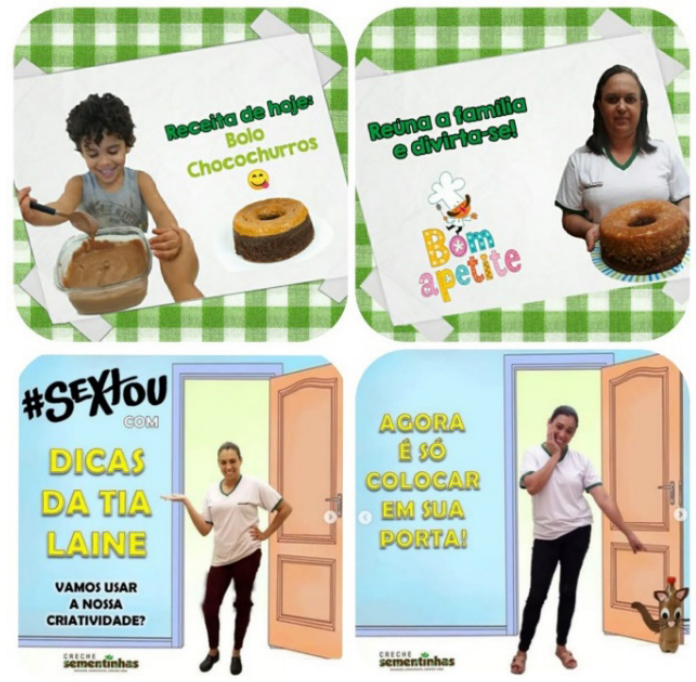

Fonte: arquivo pessoal 
Figura 11: Kits Higiene, Cartas e Tela

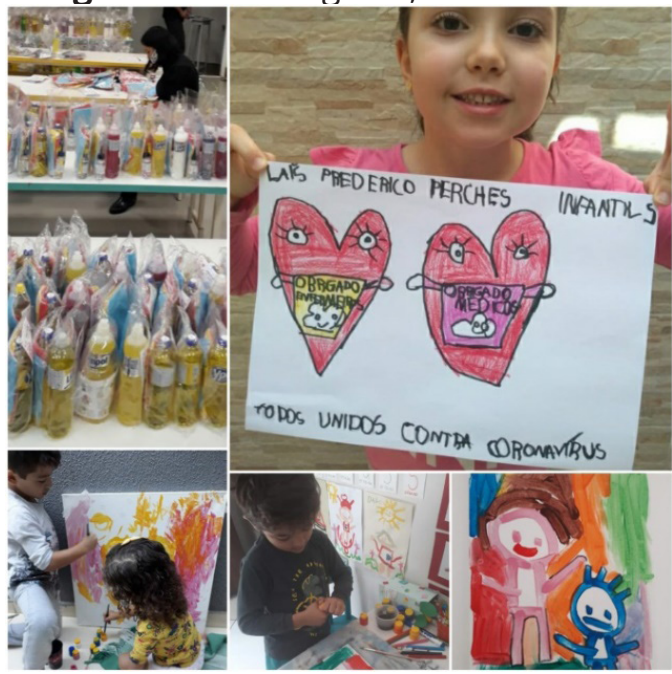

Fonte: arquivo pessoal

Figura 12: $1^{\text {a }}$ Mostra de Artes com as mães

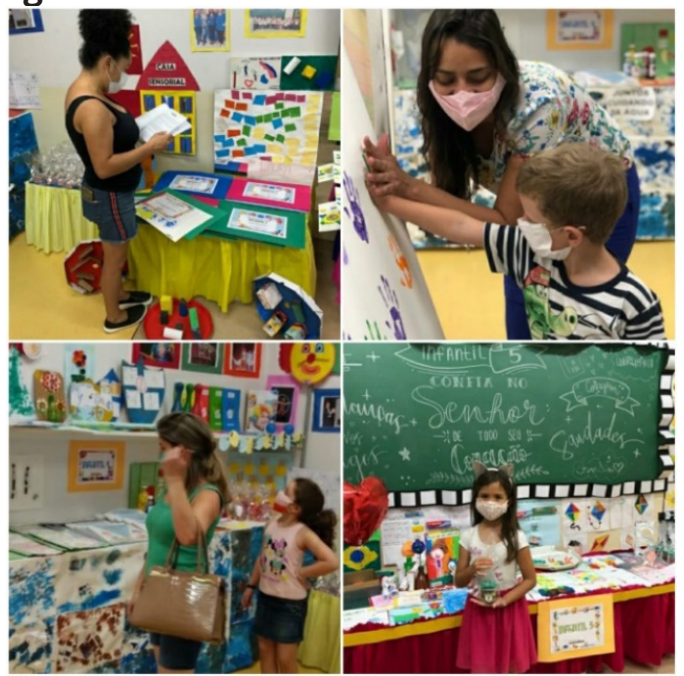

Fonte: arquivo pessoa 


\section{Considerações Finais.}

Podemos considerar, que apesar dos desafios do período de ensino remoto, sobretudo para as escolas que atuam na educação infantil, e, portanto, na fase em que a criança está em desenvolvimento de sua autonomia, linguagem e socialização e precisa da participação efetiva dos pais, a escola buscou oportunizar um ensino de qualidade, atento às mudanças e adequações necessárias para o período.

Com o presente capitulo procurou-se apresentar que a favorável relação entre escola e família foi fundamental para garantir o ensino aos alunos, uma vez em que os familiares se tornaram os mediadores das propostas de ensino durante o período de pandemia. Para auxiliá-los na condução deste desafio, a equipe escolar organizou-se, por meio de um planejamento intencional, oferecendo uma diversidade de ações que pudessem contemplar e atender às demandas dos familiares.

Resultado deste importante trabalho foi a concretização da $1^{\text {a }}$ Mostra de Artes da Escola, ocorrida em um ano pandêmico, e apreciada por toda comunidade escolar (alunos, familiares, diretores, visitantes) devido à preciosidade das produções e devolutivas dos pais neste período de ensino remoto.

Torna-se fundamental ressaltar o engajamento e o interesse da equipe escolar em mobilizar-se para corresponder com novas demandas durante 
esse processo. Houve um significativo investimento em estudo, formação, capacitação em novos aprendizados, inclusive no ambiente tecnológico (plataformas digitais, editores de vídeo, gravações de aulas, equipamentos de gravação etc.) para que o ensino ofertado pela instituição pudesse manter a qualidade e principalmente, que permanecesse $o$ vínculo afetivo com os alunos.

Baseado nos ideais da Gestão Democrática, a coordenação pedagógica buscou promover 0 envolvimento de toda equipe neste processo, aproveitando as máximas contribuições dos colaboradores em suas diferentes áreas de atuação. Desta forma, a riqueza das estratégias criadas buscou favorecer o pleno desenvolvimento do aluno.

90 Àluz destas contribuições, espera-se que o relato possa colaborar com à reflexão e ampliação de possibilidades de ações e estratégias do professor e da equipe gestora no envolvimento da família no processo de escolarização dos alunos, por meio de uma parceria favorável e harmoniosa.

É necessário pensar e repensar em práticas escolares que possam promover o envolvimento dos pais/familiares na socialização das nossas crianças.

A família é o coração da nossa sociedade. Se pretendemos construir uma sociedade forte e saudável, precisamos aprender a cuidar desse coração! 
Figura 13: Equipe escolar

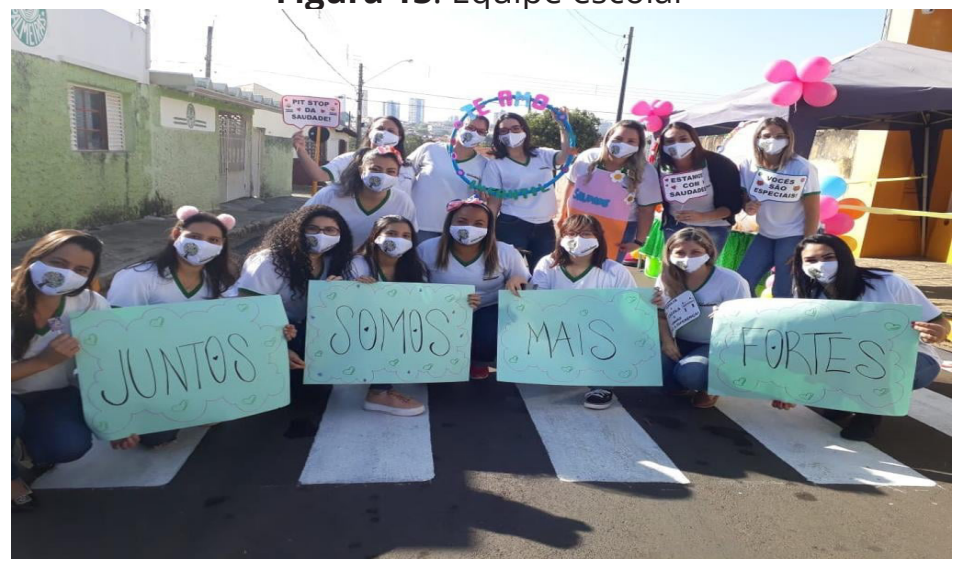

Fonte: arquivo pessoal

\section{REFERÊNCIAS}

ARCE, A. MARTINS, L. Quem tem medo de ensinar

na Educação Infantil? Em defesa do ato de ensinar. 2ªd, São Paulo: Alínea, 2010.

BERGER, P.L, LUCKMANN, T. A construção social da realidade. $33^{\mathrm{a} e d}$. Petrópolis: Vozes, 2011.

BRONFENBRENNER, U. A ecologia do desenvolvimento humano: experimentos naturais e planejados. Porto alegre: Artes Médicas, 1996.

BRONFENBRENNER, U. Bioecologia do desenvolvimento humano. Tornando os seres humanos mais humanos. Porto Alegre: Artmed, 2011.

PASQUALINI, J. C.; TSUHAKO, Y. N. Proposta pedagógica para a Educação Infantil do Sistema Municipal de Ensino de Bauru/SP [recurso eletrônico], orgs. Bauru: Secretaria Municipal de Educação, 2016.

PRADO, D. 0 que é família. Editora brasiliense. $12^{\mathrm{a}}$ ed. São Paulo, 1991. 
SAVIANI, D. Pedagogia histórico-critica: primeiras aproximações. 11 ed, Campinas: Autores associados, 2012.

VIGOTSKI, L. S.A formação social da mente. O desenvolvimento dos processos psicológicos superiores. $4^{\mathrm{a}}$ ed. Martins Fontes, 1991. (org Michel Cole ...et al).

. O desenvolvimento psicológico na infância: tradução Claudia Berliner. São Paulo: Martins Fontes, 1998

WALLON, H. A evolução psicológica da criança. S 



\title{
ARTE LITERÁRIA: \\ ARTICULAÇÃO ENTRE OUVIR, FALAR, LER E ESCREVER NA EDUCAÇÃO INFANTIL
}

\author{
Alessandra Salvador Costa Morijo \\ Alice Nicassio de Oliveira \\ Fabiana Hortolani Sartori \\ Josilaine Aparecida Pianoschi Malmonge
}

\begin{abstract}
INTRODUÇÃO
A prática de leitura insere a criança na cultura letrada, possibilitando que ela se aproprie do conhecimento do mundo real, fazendo uma ponte com o imaginário. O ato de ler ou ouvir histórias possibilita aprendizado, obtenção de informação, ampliação de vocabulário, melhoria da escrita e, principalmente, fruição e entretenimento; formando na criança os princípios do comportamento leitor, marcado por uma rotina de intimidade com o texto.
\end{abstract}

O presente artigo tem como objetivo trazer uma abordagem acerca da importância da leitura para as crianças, de acordo com cada faixa etária, analisando o desenvolvimento da criança em relação ao gosto pela leitura; apontar a leitura dos contos como ação pedagógica e apresentar a importância do incentivo da leitura desde os primeiros anos de vida.

A pesquisa está fundamentada na abordagem qualitativa (CHIZZOTTI, 2010), para tanto, foi 
considerada a análise de documentos, livros de autores da área tais como: Bettelheim (2002), Rau (2011), Referencial Curricular Nacional para a Educação Infantil RCNEI (BRASIL, 1998), Vygotsky (1999), dentre outros, possibilitando o embasamento teórico do presente trabalho.

A leitura e a escrita exercem grande importância no processo de humanização, pois, favorecem a formação das funções psíquicas superiores, capacidades estas, desenvolvidas conforme as condições socioculturais em que o sujeito está inserto. Logo, há significativa contribuição à aprendizagem e desenvolvimento da criança, desde a sua mais tenra idade, quando a prática pedagógica oportuniza o contato com a literatura infantil.

A criança se encanta ao ouvir uma história. A leitura atrai a atenção delas, uma vez que, ao ouvir uma narrativa sua natureza biológica é modificada e, assim, são desenvolvidas as formas superiores da conduta humana como, por exemplo, a atenção e a imaginação, potencializando ainda, o tato, a visão, o ouvir e o falar.

\section{Leitura: Entretenimento ou Aprendizagem?}

Com a modernização e a ampliação dos meios tecnológicos, indivíduos do Brasil e do mundo alteraram seus hábitos de leitura. Deixaram de apreciar um bom livro em detrimento do uso de computadores, vídeo games ou outros eletrônicos. Assim, a rotina de trabalho e os afazeres domésticos 
influenciam na qualidade das atividades oportunizadas às crianças objetivando o mero entretenimento, a fim de mantê-las comportadas.

Por outro lado, a prática da literatura traz benefícios não só para a aprendizagem da criança, como também, para o seu desenvolvimento emocional e formação de personalidade. O contato com a leitura propicia a informação, o enriquecimento cultural e a capacidade de expressar ideias de forma crítica, permitindo ao sujeito transformar a sociedade e ser transformado por ela. A leitura é um ato que tem fim em si mesma.

O trabalho educativo na educação infantil constitui-se em importante oportunidade para promover o interesse e o gosto infantil pela leitura.
A Base Nacional Comum Curricular (BRASIL, 2017, p. 40) descreve que:

As experiências com a literatura infantil, propostas pelo educador, mediador entre os textos e as crianças, contribuem para o desenvolvimento do gosto pela leitura, do estímulo à imaginação e da ampliação do conhecimento de mundo.

Nessa direção, uma das formas de incentivar o comportamento leitor, o gosto pela leitura e a imaginação é propor o contato com um livro adequado à faixa etária, colorido, grande e com ilustrações que chamem a atenção da criança. 
As obras infantis que respeitam seu público são aquelas cujos textos tem potencial para permitir ao leitor infantil possibilidade ampla de atribuição de sentido àquilo que lê. A literatura infantil digna do nome estimula a criança a viver uma aventura com a linguagem e seus efeitos [...] (CADEMARTORI, 2010, p. 17).

A atitude lúdica empenhada na maneira de se contar uma história pode ser ampliada ao usar objetos e representações que despertem a curiosidade, a criatividade e a imaginação infantil. Uma possibilidade é a utilização de chapéus, maquiagens, lenços e adereços, fantoche, ou ainda, uma peça misteriosa, como recursos na contação.

Como proposta prática para a sala de aula com a história Menina bonita do laço de fita de Ana Maria Machado, a sugestão é apresentar para as crianças, as jabuticabas, fruta descrita no livro, para que possam experimentar coletivamente durante o momento da leitura. Martins (2005) cita, que desde o nascimento fazemos leituras do entorno que nos cerca e, nas crianças, essas leituras são principalmente sensoriais, isto é, se manifestam através dos sentidos (tato, olfato, paladar, audição e visão) mediados pelo contato com o mundo e as experiências.

Segue aqui algumas experiências com intervenções na contação de histórias: 
Figura 1: brincadeira no parque com fantoches

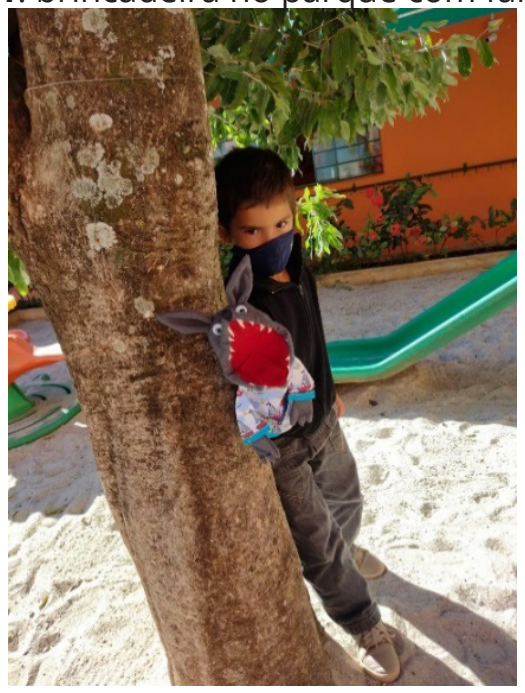

Fonte: arquivo pessoal

Figura 2: a relação da história do livro com a pintura

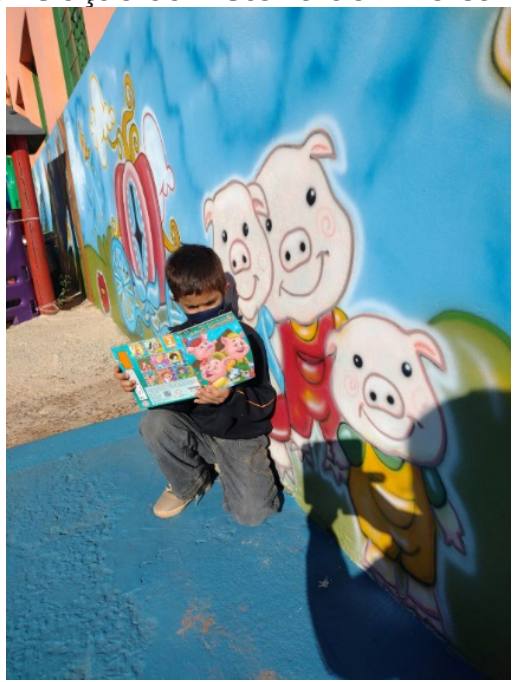

Fonte: arquivo pessoal 
Figuras 3 e 4: o faz de conta e o reconto com fantoches

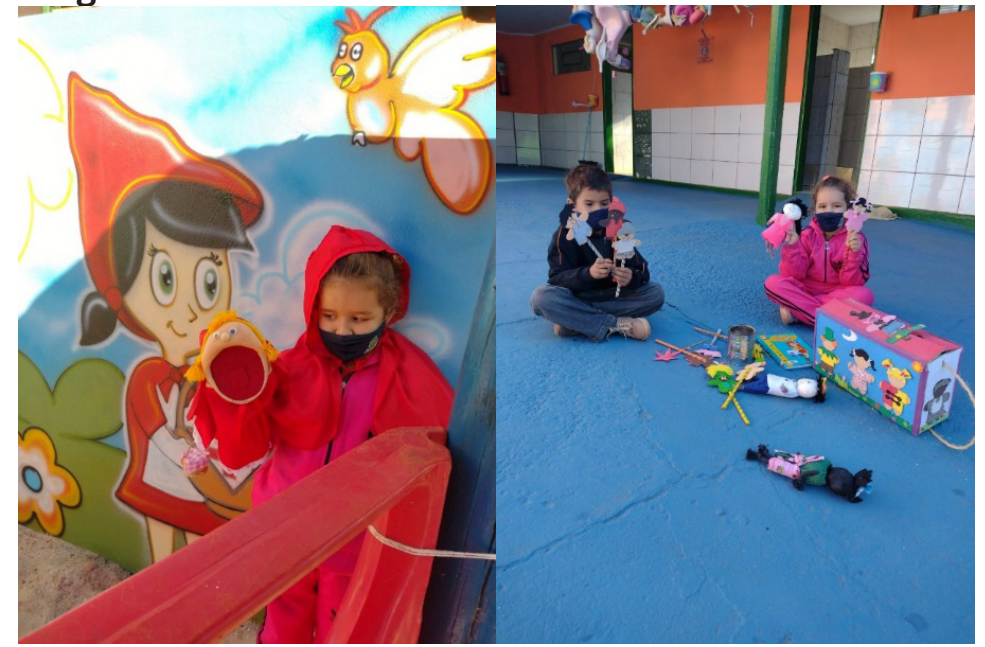

Fonte: arquivo pessoal

Assim, momentos de contação de história são transformados em brincadeira de forma prazezora e as intervenções com materiais de apoio auxiliam a prática educativa na ampliação de possibilidades de aprendizagem. Os professores e educadores até sabem que o uso da literatura infantil deve servir para forma de aprendizagem e enriquecimento e querem formar crianças leitoras que tenham prazer pela literatura. Porém, em alguns momentos, perdem a oportunidade de planejar uma aula mais lúdica.

Os contos de fada são importantes para o desenvolvimento das crianças no período da infância. Eles têm a capacidade de auxilia-las a resolver os conflitos internos que passam durante o seu processo de crescimento. 
Por meio da leitura prazerosa e divertida dos contos de fadas, suas histórias proporcionam à criança o desenvolvimento de sua personalidade e, do mesmo modo, oportunizam experiências imprescindíveis à formação de caráter.

Os professores têm nos contos de fadas um potente recurso para o trabalho pedagógico. Por possuírem uma estrutura ou simbologia própria, seus personagens são apresentados de forma simples e de fácil compreensão para as crianças. Do mesmo modo, utilizam-se de sentimentos, qualidades e defeitos reais como o medo, a alegria, a beleza, a feiura, a bondade e maldade, a coragem, a covardia e outros. Assim, as crianças fazem a relação dos contos às situações reais que vivenciam, permitindo-lhes desenvolverem estratégias para a resolução simbólica de seus conflitos internos.

Segundo o Referencial Curricular Nacional para a Educação Infantil:

O ato de leitura é um ato cultural e social. Quando o professor faz uma seleção prévia da história que irá contar para as crianças independentemente da idade delas, dando atenção para inteligibilidade e riqueza do texto para nitidez e beleza das ilustrações, ele permite as crianças construírem um sentimento de curiosidade pelo livro (ou revista, gibi etc.) e pela escrita. A importância dos livros e demais de textos e é incorporada pelas crianças, também, quando o professor organiza o ambiente de tal forma que 
haja um local especial para livros, gibis, revistas, etc., que seja aconchegante e no qual as crianças possam manipulá-los e "lê-los" seja em momentos organizados ou espontaneamente. Deixar as crianças levarem um livro para casa, para ser lido junto com seus familiares, é um fato que deve ser considerado. As crianças desde muito pequenas podem construir uma relação prazerosa com a leitura. Compartilhar essas descobertas com seus familiares e um fator positivo nas aprendizagens das crianças, dando um sentido mais amplo para a leitura. (BRASIL, 1998, p.135)

As crianças que ouvem histórias entram num mundo de encantamento e imaginação, conhecem lugares e se identificam com os personagens, entram num mundo magico, e também, produz um efeito emancipatório no leitor. Segundo Zilberman (1987, p 79),

O que o leitor oferece ao texto e o que o último Ihe devolve: revitalização do mundo ficcional em troca de um conhecimento que o posiciona mais adequamente na sua circunstância. Consequentemente a leitura enquanto tarefa de deciframento implica uma interpretação do texto e do modo escondido atrás dele, retornando o circuito para o sujeito na medida em que isso significa uma libertação de preconceitos 
Apropriar-se da prática de leitura dos contos no fazer docente é uma forma segura e eficiente de introduzir a criança no mundo literário. Logo, essa influência propicia a ampliação do universo linguístico, vocabulário e diferenciação da linguagem.

Estimular a leitura é importante, tendo em vista, que grande parte das crianças têm o seu primeiro contato com a literatura quando ingressam na escola. Assim, quanto maior for o conhecimento do professor sobre a relevância do trabalho literário, maiores serão as possibilidades de enriquecer esse momento de alegria e prazer com recursos que promovam a aprendizagem e desenvolvimento na infância. Quando a leitura não é forçada, torna-se agradável. O mundo tecnológico contemporâneo trouxe maior dificuldade em manter as crianças entusiasmadas com livros e leituras. Entretanto, a arte literária proporciona benefícios e experiências de desenvolvimento que a tecnologia não substitui.

Para que a estória realmente prenda a atenção da criança, deve entretê-la e despertar sua curiosidade. Mas para enriquecer sua vida, deve estimular-lhe a imaginação: ajudá-la a desenvolver seu intelecto e a tornar claras as suas emoções; estar harmonizada com suas ansiedades e aspirações; reconhecer plenamente suas dificuldades e ao mesmo tempo sugerir soluções para os problemas que a perturbam. (BETTELHEIM, 2002, p 13) 
É através da relação prazerosa e espontânea com os livros infantis que a imaginação se mistura com a realidade. Segundo o Referencial Curricular Nacional para a Educação Infantil (BRASIL,1998, p.141):

Práticas de leitura para as crianças têm um grande valor em si mesmas, não sendo sempre necessárias atividades subsequentes, como o desenho dos personagens, a resposta de perguntas sobre a leitura, dramatização das histórias etc. Tais atividades só devem se realizar quando fizerem sentido como parte de um projeto mais amplo. Caso contrário, pode-se oferecer uma ideia distorcida do que é ler.

Portanto, o professor que faz uso dos contos de fada em sua prática cotidiana propicia ao aluno a oportunidade de falar abertamente sobre os seus problemas, intervir em suas angústias e laços afetivos. Ademais, favorece um ambiente saudável e rico para o entretenimento e aprendizagem por meio da literatura infantil.

\section{A Influência da Leitura no Desenvolvimento da CRiança}

O professor nos dias de hoje tem um papel de extrema importância no desenvolvimento de seus alunos, pois ele é o mediador entre o conhecimento e a criança. Essa ligação intensa entre professor e aluno é papel fundamental no ambiente escolar.

A escola tem como fundamento a transmissão do conhecimento material e imaterial acumulado 
pela humanidade. É papel também apresentar o desenvolvimento da linguagem, a ler e a escrever. Nesse contexto, para o trabalho de qualidade com a literatura na escola se faz necessário a formação de professores, a fim de que estes, possam manter-se sensibilizados como leitores também. Professores que preservam a emoção de ler e sonhar, ampliam as possibilidades de escolher acervos com propriedade para formar e motivar leitores. A importância de aproximar as crianças dos livros de literatura infantil é praticamente um consenso, o contato com os contos possibilitará a criança a ter vários papéis sociais, bem como promover à socialização, a troca de experiência, o desenvolvimento de seu imaginário e a percepção para o mundo.

Falando um pouco sobre literatura pode se considerar que o papel da literatura nos primeiros anos é fundamental para que estabeleça uma relação ativa entre falante e língua, o que não ocorre sem envolvimento de afeto e emoções.

A literatura infantil exerce uma forte influência na formação da criança que emerge no adulto, tendo uma grande ferramenta para aprendizagem, pois, traz oportunidades de se organizar e compreender o mundo.

Os contos de fadas, à diferença de qualquer outra forma de literatura, dirigem a criança para a descoberta de sua identidade comunicação e também sugerem as experiências que são necessárias para 
desenvolver ainda mais o seu caráter. Os contos de fadas declaram que uma vida compensadora e boa está ao alcance da pessoa apesar da diversidade, mas apenas se ela se intimidar com as lutas do destino, sem as quais nunca se adquire verdadeira identidade. Estas estórias prometem a criança que, se ela ousar se engajar nesta busca atemorizante, os poderes benevolentes virão em sua ajuda, e ela o conseguirá. (BETTELHEIM 2002, p. 23).

Ao longo dos tempos as concepções sobre o ensino e linguagem na educação infantil sofreram modificações. No início o surgimento das creches possuía apenas o objetivo de atender crianças 106 de baixa renda, dispensando um atendimento assistencial, higienista e de cuidado. Atualmente, as políticas públicas e documentos oficiais como as Diretrizes Curriculares Nacionais para a Educação Infantil - DCNEI (BRASIL, 2010) e a BNCC (BRASIL, 2017) normatizam que o trabalho de cuidar e educar crianças pequenas são indissociáveis ao processo educativo.

Considerando que as DCNEI (BRASIL, 2010, p.12) define a criança como:

Sujeito histórico e de direitos que, nas interações, relações e práticas cotidianas que vivencia, constrói sua identidade pessoal e coletiva, brinca, imagina, fantasia, deseja, aprende, observa, experimenta, 
narra, questiona e constrói sentidos sobre a natureza e a sociedade, produzindo cultura.

Os RCNEI (BRASIL, 1998, vol. I p.23) apontam que:

Educar significa propiciar situações de cuidados brincadeiras e aprendizagens orientadas de forma integrada e que possam contribuir para o desenvolvimento das capacidades infantis de relação interpessoal, de ser e estar com os outros em uma atitude básica de aceitação, respeito e confiança, e o acesso, pelas crianças, aos conhecimentos mais amplos da realidade social e cultural. Neste processo, a educação poderá auxiliar o desenvolvimento das capacidades de apropriação e conhecimentos e conhecimento das potencialidades corporais, afetivas, emocionais, estéticas e éticas, na perspectiva de contribuir para a formação de crianças felizes e saudáveis.

Nessa direção, as práticas educativas desenvolvidas na escola devem buscar situações de aprendizagens que sejam próximos ao mundo da criança. O trabalho com literatura facilita essa proximidade, pois muitas situações relatadas nos contos de fadas e fábulas fazem parte do universo infantil.

A educação infantil ao promover experiências significativas de aprendizagem da língua, por meio do trabalho com linguagem oral e escrita, se constitui em um dos espaços de ampliação das capacidades 
de comunicação e expressão, bem como de acesso ao mundo letrado pelas crianças. Essa ampliação está relacionada ao desenvolvimento gradativo das capacidades associadas às quatro competências linguísticas básicas: falar, escutar, ler e escrever.

O desenvolvimento infantil da criança através da leitura é um elemento fundamental para a participação do indivíduo na sociedade, pois esta ligação com a leitura levará a interações com o meio cultural e desde os primeiros anos de vida com o mundo escrito

A leitura é o primeiro contato que a criança tem com os livros quando a mãe, o pai, os avós, professores ou outras pessoas lhe contam as mais diversas narrativas. É a partir desta iniciativa que 108 começa a sua interação com as histórias e contos infantis que, por sua vez, se relacionam com as histórias de vida da própria criança.

É neste primeiro contato que ela começa a se interessar e desenvolver assim, a curiosidade e a imaginação, que são fundamentais para o estabelecimento de sua identidade e compreensão das situações do dia a dia. Outro fato interessante é o vínculo afetivo que se estabelece entre quem conta as histórias e os ouvintes.

Para que a leitura seja estimulada é necessária uma maior valorização das bibliotecas, os professores por exemplo, podem estar levando os alunos para visitas a bibliotecas, ressaltando quanto conhecimento está acumulado nas prateleiras, despertando a curiosidades de seus alunos. 
Segundo o RCNEI (BRASIL, 1998, p. 163), "as vivencias, as histórias, os modos de vida, os lugares e mundo natural são para as crianças parte de um todo integrado". A imaginação dos ouvintes vai além, possibilitando que desenvolva o seu prazer na leitura, o seu pensar, o desenhar, o criar, o escrever e o recriar dentro de seu imaginário. Nesse momento em que vivemos hoje cheio informações prontas, tecnologias avançadas, a literatura é primordial, pois, a criança que não tiver seu imaginário fluindo, no futuro poderá ser um indivíduo sem criatividade e sem sensibilidade para compreender sua realidade.

Por isso devemos garantir essa experiência de narrativa desde os primeiros anos de vida, para que o desenvolvimento de seu pensamento lógico e sua imaginação não sejam comprometidos futuramente, conforme afirma Vygotsky (1992. P.129) "a imaginação é um momento totalmente necessário, inseparável do pensamento realista".

Ao se distanciar da realidade através de uma história, é fundamental para o entendimento mais profundo da realidade que se vive.

Afastamento do aspecto extremo aparente da realidade dada imediatamente na percepção primaria possibilita processos cada vez mais complexos com ajuda dos quais a cognição da realidade se complexifica e se enriquece. (VIGOTSKY 1992, p.129) 
As crianças, especialmente as de classes sociais menos favorecidas estão inseridas em uma sociedade letrada, porém, sem oportunidade de acesso ou estímulos a esse conhecimento, gerando desigualdades nos resultados de aprendizagens e inúmeras injustiças sociais. Um indivíduo alfabetizado não é necessariamente um indivíduo letrado. Segundo Vygotsky (1991, p.133):

Ensinar a escrita nos anos pré-escolares impõe necessariamente que a escrita seja relevante à vida(...) que as letras se tornem elementos da vida das crianças, da mesma maneira como, por exemplo a fala. Da mesma forma que as crianças aprendem a falar, elas podem muito bem aprender a ler e a escrever.

Ademais, entende-se então, a importância de se trabalhar desde cedo na educação infantil as articulações entre o ouvir, falar, ler e escrever mediante a literatura, contribuindo para a formação integral da criança.

\section{Considerações Finais}

Tratamos aqui, de apesentar o que foi trabalhado através de estudos e pesquisas, a significância das práticas de leitura no desenvolvimento das crianças e sua articulação entre o ouvir, falar, ler e escrever. Logo, como a metodologia no processo de ensino pode contribuir e intervir nesse processo 
de aproximação das crianças com o mundo real, da linguagem e da escrita.

Formar leitores, ouvintes, escritores assíduos coloca todos os educadores diante de um grande um desafio, despertar o interesse pela leitura que irá contribuir na sociedade e em suas vidas, possibilitando novos olhares sobre o que os cercam nos dias de hoje. Descobertas causadas pelo encanto dessas práticas, através de livros e todas as ferramentas riquíssimas só tem a contribuir para o desenvolvimento intelectual das crianças, ampliando a criação, a imaginação, a exploração de forma lúdica e prazerosa onde o conhecimento se torna presente.

Pôde-se entender também, a contribuição fundamental para a formação da personalidade das crianças e que as diversas situações vividas através de seu imaginário auxiliam no desenvolvimento emocional. A pesquisa mostrou que para a criança desenvolver o interesse por uma história, esta deverá despertar a curiosidade e povoar o imaginário infantil.

Dessa forma, pode-se afirmar que o estudo e a pesquisa foram de grande importância para prática educativa que relaciona as articulações entre o ouvir, falar, ler e escrever na educação infantil. O segredo maior de todas essas articulações é o envolvimento que ela nos proporciona em um mundo feito de palavras, onde ouvindo e falando pode desenvolver na criança uma aprendizagem significativa. 


\section{REFERÊNCIAS}

BRASIL. Ministério da Educação. Base Nacional Comum Curricular. Brasília: MEC/SEB, 2017. Ministério da Educação e do Desporto. Secretaria da Educação

Fundamental. Referencial Curricular Nacional para a Educação Infantil.

Documento Introdutório. Brasília: MEC/SEF, 1998. v. 1. BETTELHEIM, Bruno. A psicanálise dos contos de fadas. 16.ed. Rio de Janeiro: Paz e Terra, 2002.

CADEMARTORI, L. O que é literatura infantil. $2^{a}$ edição. São Paulo: Brasiliense, 2010.

CHIZZOTTI, A. Pesquisa qualitativa em ciências humanas e sociais 3. ed. Petropólis:Vozes, 2010.

GIL,A.C.Como elaborar projetos de pesquisa.4.Ed -São Paulo: Atlas, 2002.

MARTINS, M. H. O que é leitura. São Paulo: Brasiliense, 2005

RAU, M.C.T.D. A ludicidade na educação infantil: uma atitude pedagógica. Curitiba, IBPEX, 2011.

VIGOTSKY, L. S. Formação social da mente. Trad. José Cipolla Neto et al. São Paulo, Martins Fontes, 1991.

VIGOTSKY, L. S. O desenvolvimento psicológico na infância. São Paulo: Martins Fontes, 1992.

VIGOTSKY, L. S. O desenvolvimento psicológico na infância. São Paulo: Martins Fontes, 1999.

ZILBERMAN, R A literatura infantil e o leitor,In: CADERMATORI, L; ZILBERMAN, R. literatura infantil: autoritarismo e emancipação. São Paulo: Ática, 1987. (coleção Ensaios). 


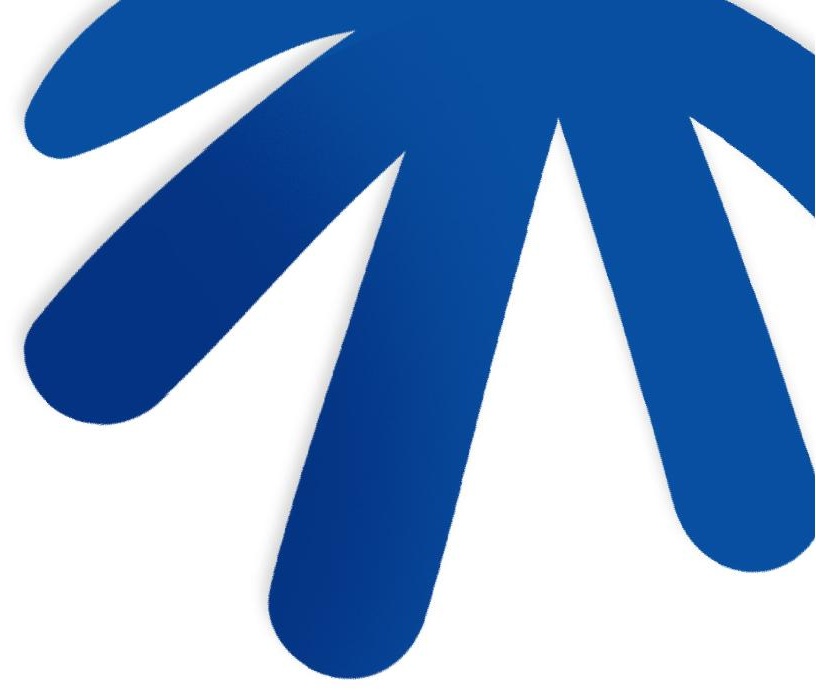




\title{
BIOMA CERRADO: UM CONTEÚDO PARA ALÉM DAS CIÊNCIAS NATURAIS NA EDUCAÇÃO INFANTIL
}

\author{
Lígia Maria Ramazzini Remaeh \\ Josilaine Aparecida Pianoschi Malmonge \\ Sintia Otuka Rossi
}

INTRODUção

Historicamente a Educação Infantil teve em seu início um caráter assistencialista. Exercia, quase que exclusivamente, o papel de cuidar das crianças pequenas com o objetivo de substituir os cuidados do lar. Nascimento (2004) afirma que a Educação Infantil foi criada a partir de uma visão assistencial e filantrópica. Nesse sentido, fundamentadas na concepção de que as famílias que se utilizavam desse serviço eram desorganizadas, desestruturadas e desequilibradas, as escolas de crianças pequenas tinham a tarefa de educá-las, consequentemente, ensinando as famílias a cuidar de seus próprios filhos (EHRENBERG, 2014).

Hoje a Educação Infantil possui especificidades que ultrapassam o "cuidar", envolvem as situações educativas, o que traz mais complexidade às ações dos profissionais envolvidos, pois o cuidar e o educar são indissociáveis nessa fase de desenvolvimento. Busca-se estruturar um fazer pedagógico que contemple tanto os cuidados necessários ao desenvolvimento da criança, quanto 
os conhecimentos a serem por ela apropriados (OLIVEIRA-FORMOSINHO, 2002).

Compreender que áreas de conhecimentos específicos também devem fazer parte da formação dos indivíduos integrantes da Educação Infantil foi outra conquista obtida a partir de fundamentos teóricos de vários pesquisadores. Neste ponto da trajetória já se visualizava a escola como local de transmissão de conhecimento científico, superando o senso comum estabelecido nos ambientes externos à esfera escolar.

Todo conhecimento historicamente construído deve ser transmitido para as próximas gerações de maneiraformalecientífica pela escola. Tambémcabe ao ambiente escolar, o papel de formar indivíduos

116 críticos diante do resultado de suas ações no meio onde estão inseridos. Nenhuma dessas conquistas é possível ser alcançada sem a intencionalidade pedagógica e o planejamento de ações, em busca dos resultados traçados por objetivos claros e adequados a fase de desenvolvimento.

O planejamento é um procedimento de pesquisa do cotidiano que exige escolhas intencionais, sem exclusão da necessidade de aprofundamento teórico somado a sensibilidade, criatividade e comprometimento com a vida desses seres humanos. Ostetto (2000, p. 177) afirma que

O planejamento educativo deve ser assumido no cotidiano como um processo de reflexão, pois, mais do que ser um papel 
preenchido, é atitude e envolve todas as ações e situações do educador no cotidiano do seu trabalho pedagógico. Planejar é essa atitude de traçar, projetar, programar, elaborar um roteiro pra empreender uma viagem de conhecimento, de interação, de experiências múltiplas e significativas para com o grupo de crianças. Planejamento é atitude crítica do educador diante de seu trabalho docente.

Bauru, uma cidade do centro-oeste paulista, possui dois biomas: Mata Atlântica e Cerrado. Originalmente, a vegetação típica da Mata Atlântica era predominante. Porém, devido a uma série de motivos, o Cerrado se sobressaiu em relação ao primeiro bioma.

Conhecer os potenciais e as necessidades do bioma que é o cenário de nossas vivências é essencial. Desde muito cedo, a criança estabelece relação com o mundo físico e natural, surgindo dúvidas e curiosidades. A observação, a exploração, a experimentação e a comunicação direta com os que a rodeiam, permite às crianças construir conhecimentos práticos, sincréticos sobre seu entorno (PASQUALINI; TSUHAKO, 2016).

Tal como salienta Saviani (2013, p.287),

[...] o que não é garantido pela natureza tem que ser produzido historicamente pelos homens, e aí se incluem os próprios homens. Podemos, pois, dizer que a natureza humana não é dada ao homem, mas é por ele produzida sobre a base da natureza biofísica. 
Sendo assim, para além da dinâmica de relações entre os fenômenos naturais, o ser humano é um agente de transformação, cuja forma de intervenção se dá a partir do trabalho, acarretando a transformação da natureza pela sociedade.

O estudo do bioma local na Educação Infantil é mais que uma oportunidade de conhecimento do entorno em que se está inserido. É a possibilidade de conhecer e reconhecer os efeitos de ações individuais e coletivas no ambiente.

A utilização deste conteúdo como tema gerador na Educação Infantil, representa a ampliação da oportunidade de observação, percepção e composição do Cerrado, agregando desde a ampliação do vocabulário das crianças pequenas 118 até o conhecimento de novas espécies e, incluindo o desenvolvimento da percepção de conceitos matemáticos, como a produção e interpretação de gráficos.

Oprojeto“OBiomaCerradopelo olhardaEducação Infantil" objetivou ampliar a aprendizagem de um grupo de crianças de quatro a cinco anos de uma escola de Educação Infantil municipal no interior do estado de São Paulo, trazendo este bioma como tema gerador das ações educativas planejadas para aquele ano, bem como, construindo valores de base para a potencial formação de cidadãos eticamente comprometidos com seu local de inserção no ambiente e na sociedade. 
Como Trabalhar o Bioma Cerrado na Educação Infantil?

Os conteúdos de Ciências Naturais abordados pelos professores, muitas vezes, podem resumirse na obrigação em trazer respostas para dúvidas do cotidiano, mesmo na presença de um currículo base e norteador. De forma deficitária na formação das crianças pequenas, não agregam abordagens para o desenvolvimento da criticidade em relação às ações que estes indivíduos estão realizando, nem mesmo integra a conteúdos de outras áreas de conhecimento.

Dentro da esfera dos conhecimentos na área de Ciências Naturais, a temática ambiental vem sendo considerada como emergencial pela nossa sociedade, tendo em vista, que os impactos gerados pela ação antrópica têm ocasionado grande desequilíbrio nos biomas.A escola potencialmente pode ser o grande elo reconstrutor dessa prática humana, visando reorganizá-las no seu entorno.

Partindo da premissa sobre importância da transmissão de conhecimentos historicamente produzidos e do desenvolvimento da criticidade desde a etapa mais tenra da existência humana, a Educação Infantil é, portanto, o local inicial dessa formação com reflexo perpétuo de suas ações nos sujeitos em formação e, sendo assim, deve ser lapidado com intencionalidade e planejamento.

Nessa etapa educacional há um grande potencial transformador e recrutador de esforços para se compreender e agir no meio, o que facilita enormemente a apropriação de conceitos e a 
incorporação de atitudes que contribuem para a conquista de melhorias no entorno ambiental da sociedade em que estamos inseridos.

Para Arce (2011) é "a curiosidade e a fascinação das crianças, que levam à investigação e à descoberta dos fenômenos naturais". Esse interesse deve ser conduzido e planejado pelo professor de modo que supere os conhecimentos práticos em direção à apropriação conceitual do mundo. Isso não significa que a curiosidade e o interesse das crianças devam ser ignorados, mas tomados como ponto de partida para uma percepção dos fenômenos naturais e suas peculiaridades. A apreensão desses conhecimentos enriquece seu repertório, estimula sua criatividade e possibilita o 120 desenvolvimento das funções psíquicas superiores, isto é, aquelas que dependem da atividade social mediada e que não são dadas geneticamente.

Sendo assim, o ato de planejar nos primeiros anos da Educação Infantil, traz implícita a necessidade de reconhecer a intencionalidade pedagógica em todos os momentos de ação propostas às crianças. Também inclui reconhecer a potencialidade das crianças pequenas e compreendê-las como sujeitos comunicativos, com necessidades e quereres, aspectos que exigem, acima de tudo, escuta e observação de suas formas de socialização (BONDIOLI, 2002; ROCHA, 2008; SARMENTO, 2005).

Para proporcionar a esse grupo de crianças participantes uma formação de base para serem potencialmente cidadãos conscientes de seus atos 
e na construção de uma sociedade ambientalmente viável, uma sequência de ações foi desenvolvida durante o ano letivo de 2017 por meio do projeto "O Bioma Cerrado pelo olhar da Educação Infantil", envolvendo todas as crianças de uma Unidade Escolar, de 6 meses a 6 anos. No entanto, o relato dessa experiência será composto apenas pelas ações desenvolvidas com crianças entre 4 a 5 anos de uma das turmas da escola.

\section{O Alfabeto do Cerrado}

A importância de oportunizar o contato da criança com estímulos verbais e não verbais é fundamental no processo de desenvolvimento dos indivíduos. De acordo com Pasqualini e Tsuhako (2016, p.198),

A escrita constitui-se em instrumento cultural complexo, cuja apropriação tem início num processo anterior ao ensino sistematizado das letras. A princípio a criança se relaciona com as coisas escritas sem compreender o significado delas e, mais tarde, na trajetória escolar, ela perceberá o caráter de signo auxiliar, que simboliza diretamente os objetos e as situações designadas, desempenhando uma função mnemônica de planejamento, registro e comunicação.

Nas turmas de crianças de 4 a 5 anos incentivamos o reconhecimento de letras e números presentes no cotidiano. E é de grande interesse da maioria essa aprendizagem. 
A partir do tema gerador Cerrado, fizemos uma relação entre as letras do alfabeto e componentes desse bioma, por exemplo, o "A" da anta, a letra "I" do ipê e até mesmo o " $\mathrm{H}$ " do humano, pois somos parte do ambiente em que estamos inseridos.

Cada letra não representava apenas um desafio gráfico para a escrita ou reconhecimento: ela tinha uma relação com algum elemento autótono do ambiente em que estávamos inseridos.

Dessa forma, passamos em cada letra fazer uma caracterização aprofundada daquele ser vivo ou situação, sempre trazendo a relação que este desenvolvia com a totalidade do ambiente.

Construímos um jogo da memória contendo as letras e as fotos representadas pelas letras. Também 122 fizemos um portfólio individual, onde cada criança registrava em uma folha a letra e o desenho que representava as discussões realizadas sobre as relações daquele elemento com o ambiente.

Ao final do processo, a maioria das crianças reconhecia com facilidade as letras, relacionava com as imagens apresentadas e sabia explicar qual a relação daquela imagem com a totalidade do ambiente.

\section{A OcorrênCia de Chuvas em Gráficos}

O bioma Cerrado possui condições climáticas, ou seja, fatores abióticos peculiares a sua localização e características ambientais. Caracteriza-se teoricamente, por apenas duas estações: verões chuvosos e invernos secos. 
Para verificar se essa afirmativa era real, as crianças acompanharam com regularidade diária a pluviosidade, utilizando um calendário diário coletivo que foi ampliado. No início de cada tarde, o auxiliar do dia (as crianças eram organizadas de acordo com uma lista para auxiliarem a professora nas ações diárias, de forma que não gerasse conflito e todas participassem) fazia o desenho representativo no dia do calendário equivalente: um sol para dias sem chuva, um sol com nuvem para dias nublados, uma nuvem com gotas em dias chuvosos.

Ao final de cada mês, a partir dos registros, era montado um gráfico com três colunas utilizando quadrados previamente recortados das cores amarelo, cinza e azul. Contávamos quantos dias o sol estava desenhado e com cola realizávamos a fixação em uma folha, no formato de uma coluna, com os quadrados amarelos. O mesmo era feito com os dias nublados, utilizando quadrados cinza e com os dias chuvosos, representando com quadrados azuis. O mês era escrito acima do gráfico e na parte de baixo, todos os presentes escreviam o nome (da forma que conseguiam) para identificar a participação no processo.

Pasqualini e Tsuhako (2016, p.209) afirmam que,

No contexto da educação escolar, não se pode pensar a matemática apartada de sua função social nem conceber o seu ensino como algo separado das experiências da criança. A transmissão desse importante 
conteúdo cultural-científico pela escola de educação infantil deve orientar-se pela relação entre o conhecimento e as práticas sociais; ou seja, a matemática como mediação que enriquece e qualifica as experiências e vivências de cada criança.

Naquele ano houve uma peculiaridade: no mês de junho choveu bastante, o que contrariava a ideia inicial de que neste mês não choveria. A partir dessa conclusão, buscamos respostas para o motivo dessa ocorrência nada comum nesse mês. As famílias ajudaram bastante neste processo, pesquisando inclusive vídeos com as crianças para entenderem o que estava ocorrendo.

Verificamos que essa mudança de padrão de 124 chuvas possui relação com o desmatamento excessivo. Então precisávamos comprovar como as plantas podiam influenciar nesse ciclo.

\section{O Ciclo Hidrológico em um Terrário}

Santos (2012, p.41) traz uma reflexão fundamental sobre o papel da ciência:

A ciência faz um esforço para compreender o mundo, sua estrutura e suas leis. Busca regularidades, elabora teorias e estas devem provar sua validade no trato dos fenômenos. Adotamos a visão da ciência como saber capaz de levar o homem ao conhecimento das relações fundamentais que estruturam nosso universo. A ciência é um saber totalizante. 
E essa busca, certamente deve ser iniciada nos primeiros anos de frequência em ambientes escolares, local onde o saber científico é transmitido como parte do processo de ensino e aprendizagem.

No mês de agosto retomamos nossa conversa sobre a influência das plantas no ciclo das chuvas e, para comprovar cientificamente nossas discussões e testar as hipóteses apresentadas, montamos um terrário.

A primeira preocupação foi pensarmos em um material de fácil acesso, porém transparente, e que não significasse risco para as crianças manusearem. Optamos por utilizar uma garrafa plástica de água de 5 litros. Cortamos a parte de cima, mas não descartamos, para posteriormente utilizar como vedação.

Montamos as camadas equivalentes ao solo colocando no fundo da garrafa pet pedrinhas para aquário, sobre elas carvão vegetal e depois terra adubada. Também acrescentamos minhocas para representarmos os animais e uma planta suculenta. Por último colocamos água em quantidade suficiente para umedecer a terra, mas sem encharcar. Voltamos a parte superior da garrafa que havia sido retirada e vedamos com fita transparente. Colocamos em local onde o sol do início da manhã estava presente, mas sem o contato com o sol da tarde.

As crianças observaram durante várias semanas o experimento e verificaram que a água evaporava 
através das folhas da planta e como o ambiente era fechado, esse vapor não tinha para onde ir. Quando a umidade aumentava até o ponto de saturação, a água se condensava nas paredes da garrafa e ocorria um fenômeno similar à chuva, assim a água voltava ao solo e o ciclo recomeçava.

Durante as observações conversamos muitas vezes sobre o fato de que sem as plantas o ciclo era interrompido e que, portanto, o desmatamento trazia prejuízos graves para todos nós.

\section{A Aula no Jardim Botânico}

A Proposta Pedagógica para a Educação Infantil do Sistema Municipal de Ensino de Bauru (PASQUALINI; TSUHAKO, 2016) na página 277,

126 descreve a importância de ações em ambientes externos, como Zoológicos e Jardins Botânicos, que proporcionem o ensino e as vivências na área de Ciências Naturais.

No momento desta atividade que descreveremos, as crianças já compreendiam como as plantas agiam nesse ciclo que envolvia a chuva. Mas, e no período em que não chovia? Como as plantas podiam sobreviver se ninguém iria até elas regar?

Fomos então conhecer as plantas características do Cerrado. O Jardim Botânico Municipal da cidade de Bauru é composto por uma grande variedade de espécies nativas do Cerrado e possui ações de Educação Ambiental para receber e orientar grupos de várias idades de acordo com agendamento 
prévio e solicitação do professor sobre as demandas necessárias de aprendizagem.

Recepcionados por um biólogo pudemos conversar sobre as profundas raízes das plantas deste bioma que utilizam essa estrutura para retirar água de lençóis freáticos.

Também conhecemos várias espécies de plantas que havíamos estudado no Alfabeto do Cerrado e que foram reconhecidas por algumas das crianças pelas fotos que havíamos visto na escola.

O biólogo também contou para as crianças sobre as principais características das árvores do Cerrado: troncos tortos e casca grossa. Fizemos ações propostas por ele, como representarmos com nossos corpos como eram as árvores e, as crianças, a partir deste dia, passaram a reproduzir em suas brincadeiras essa posição das árvores do Cerrado. Usavam essas características como "super poderes" em suas interpretações, pois sabiam que para as árvores do Cerrado essas propriedades eram muito importantes.

\section{Os Animais do Cerrado}

Outra atividade externa realizada foi uma aula no Zoológico Municipal de Bauru. Nosso momento neste local foi acompanhado por um biólogo que ali trabalhava e, iniciamos nosso trajeto no Centro de Educação Ambiental com uma conversa sobre os animais do Cerrado.

Como havíamos trabalhado ao longo de muitos meses sobre esses animais, o interesse das crianças 
em conhecê-los foi nítido e eles sabiam conversar com a bióloga sobre os animais e as dúvidas que tinham. Os responsáveis pelo local relataram sobre a diferença de uma turma ser trazida ao Zoológico com intencionalidade e preparados sobre o tema.

Lá tivemos a oportunidade de visitarmos a anta, - lobo guará que estava com filhotes, a coruja buraqueira, a onça parda, o tamanduá e o bugio. Relembramos as características deles e ouvimos novas informações da bióloga que acompanhou o grupo, sempre destacando o papel de cada um no ambiente e explicando que aqueles animais não foram retirados do ambiente natural que viviam para serem expostos para a população.

TOdAS AS ÁRVORES SÃo IgUaIS?

Por muito tempo houve a reprodução de desenhos estereotipados como sendo "padrões corretos" de registro. Com o passar dos anos verificou-se o quão limitadora essa prática era.

Ainda recebemos muitas crianças com esses padrões arraigados, vindos da cultura familiar. Para romper com essa prática, utilizamos a observação e registro por desenho das árvores do Cerrado.

É tarefa do ensino de Artes Visuais, portanto, assegurar que as crianças vivam intensas experiências, estabelecendo relações entre diferentes modos de utilização dos elementos visuais (sintaxe visual), sendo capazes de decodificar e interpretar 
composições (recepção/leitura) e de compor com elas (criação) (PASQUALINI; TSUHAKO 2016, p. 462)

Devido a ação de uma entidade filantrópica da cidade, nossa escola possuía árvores do Cerrado plantadas no parque. Elas eram miúdas, algumas com troncos muito finos, outras com troncos grossos e muitos galhos. As folhas tinham diferentes formatos e, algumas árvores, perdiam as folhas no período do inverno (caducifolia).

Iniciamos as ações fazendo a impressão das folhas com guache em folhas de cartolina e verificamos os diferentes formatos. Na sequência iniciamos o registro semanal, por meio de desenho, das árvores do nosso parque.

Ao final do primeiro semestre as crianças já não desenhavam mais árvores com o padrão estereotipado. Muitas inclusive desenhavam árvores sem folhas. Reconheciam características típicas de árvores do Cerrado e comentavam quando viam desenhos expostos de outras turmas da escola onde estavam representadas por meio de desenhos, árvores que nada se assemelhavam às reais.

\author{
Ampliação do Vocabulário, Percepção \\ do Som Inicial e Final das Palavras \\ Segundo Pasqualini e Tsuhako (2016, p.181-182), \\ [...] é de responsabilidade da Educação \\ Infantil, promover a aprendizagem da língua
}


materna, a partir da inserção da criança na comunidade adulta onde prevalece a diversidade dos gêneros discursivos, possibilitando o acesso da criança aos gêneros secundários [...]

Vygotsky (apud DOLZ; SCHNEUWLY, 2007, p.88), afirma que 'a aprendizagem humana pressupõe uma natureza social específica e um processo por meio do qual as crianças ascendem à vida intelectual daqueles que as cercam'. Mas deve-se esclarecer que não é um contato sem direcionamento que agregará evolução nesse processo. O contato da criança com esse universo deverá ser mediado pelo professor, sendo que a transição de uma etapa da linguagem para outra melhor elaborada não se dará de forma espontânea, mas sim, por meio de uma ação intencional.

A partir da elaboração do Alfabeto do Cerrado, verificamos que além da ampliação do vocabulário das crianças, elas começaram a buscar o som inicial de outras palavras a partir das letras iniciais dos elementos que estudamos no alfabeto.

A partir dessa verificação colocamos cartolinas nas paredes da sala, na altura que as crianças alcançavam. Essas cartolinas continham as letras iniciais do alfabeto e a foto de um elemento do Cerrado que a representava. As crianças foram convidadas a trazer imagens que representassem elementos com os sons iniciais das letras do alfabeto e, no início da rotina diária, podiam colar na cartolina 
equivalente. Em poucos dias as cartolinas foram preenchidas. Aqueles que não traziam recortes, faziam desenhos que representavam elementos com o som inicial das letras e também colavam.

Quando já haviam se apropriado do reconhecimento do som inicial, iniciamos um trabalho de reconhecimento dos sons finais (rimas). Começamos com brincadeiras de rima no parque, no refeitório com o nome dos alimentos, nas músicas, com os nomes das crianças e apresentando poesias com rimas. Após muitas brincadeiras para o desenvolvimento da percepção, a proposta foi feita para as crianças falarem poesias com os elementos do Cerrado.

Atuando como escriba e mediadora das falas, o registro de onze poemas foi feito ao longo dos dois últimos meses daquele ano letivo, antes da apresentação dos resultados na Mostra Cultural da escola.

Dentre eles, cito a seguinte produção realizada pelas crianças:

\section{O TAMANDUÁ \\ GARRAS GRANDES, TRÊS DEDOS \\ E UMA LÍNGUA BEM COMPRIDA! \\ SABE QUAL SUA COMIDA PREDILETA? \\ FORMIGA COM MELECA!}

\section{Mostra Cultural}

A unidade escolar onde ocorreram as ações deste projeto, nunca havia realizado uma ação 
ao final do ano para mostrar as objetivações produzidas pelas crianças. No ano de 2017 essa prática foi iniciada com a recepção dos pais em uma escola organizada em espaços e, cada um deles, contendo os resultados das ações desenvolvidas pelas crianças.

Ao final da Mostra Cultural, antes do encerramento, as crianças apresentaram uma interpretação por meio de movimentos corporais a partir da narração de um texto sobre o Cerrado. A cada animal citado, a cada movimento, as crianças organizadas em círculos por turmas, interpretaram as ações descritas. Segue o texto utilizado:

$$
\text { "1, 2, } 3
$$

Era uma vez...

Um lugar muito bonito! Era uma mata perto da cidade de Bauru.

Nesse lugar havia plantas com flores super coloridas... eram flores amarelas, vermelhas, roxas e brancas.

Essas flores eram de árvores como ipês, jatobás, copaíbas, pequis e tantas outras.

Mas todas essas árvores tinham algo em comum: raízes profundas, caule grosso e eram muito tortas.

Sabem onde temos árvores desse jeito? No Cerrado!

E lá, nesse Cerrado também viviam vários animais: corujas buraqueiras, antas, tamanduás, bugios pretos e até o lobo guará!

Todos viviam muito felizes por lá! Até que um dia... 
Um homem que passava lá por perto resolveu fazer algo sem pensar: jogou um cigarro aceso no meio das árvores do Cerrado.

Sabem o que aconteceu?

Pegou fogo na mata!

Os animais ficaram muito preocupados quando viram o fogo aumentando cada vez mais!

Mas vocês pensam que eles ficaram parados?

Eles se uniram (as crianças dão as mãos), e se organizaram para apagar o fogo.

Eles colocavam ÁGUA na boca, VOLTAVAM perto do fogo e APAGAVAM!

Mas não foi o suficiente para apagar o fogo!

Vamos novamente?

ÁGUA na boca! VOLTAR! APAGAR!

Ufaaaa! O fogo apagou!

Ao final todos estavam cansados da correria e resolveram DESCANSAR.

O Cerrado estava salvo! Mas até quando?

Quanto tempo ainda vamos levar para entender que as plantas e animais dependem de nós para sobreviver?

Só existe uma coisa que temos certeza: somos parte do ambiente e se destruirmos tudo o que está ao nosso redor, não sobreviveremos!

E foi com essa certeza que, naquela noite, todos os animais FORAM DORMIR... acreditando que ainda há chance das pessoas entenderem que é possível todos os seres vivos se respeitarem e compartilharem o mesmo ambiente!

E é assim que vai terminando essa história... Uma história que da brincadeira 
vira realidade, e que espera que dentro de cada um tenha despertado a vontade de cuidar daquilo que é nosso!

Para lembrar a todos da nossa responsabilidade, a Escola Pinóquio agora tem um grito de guerra. Qual é o nosso grito de guerra, pessoal: SALVEM O CERRADO!"

\section{Considerações Finais}

Um caminhar longo, com percursos desafiadores e muitas devolutivas de satisfação e sucesso na aprendizagem: essas foram as ações que permearam essa trajetória.

Escutar, observar e planejar fazem parte de uma proposta contemplada pela intencionalidade pedagógica. Saber o que se deseja ensinar,

134 reconhecer para quem se quer transmitir o conhecimento e adequar estratégias para essa finalidade é a base para se conseguir o objetivo principal da escola: a transmissão do conhecimento científico.

Os mais diversificados conteúdos podem ser transmitidos na Educação Infantil, incluindo o bioma em que este indivíduo está inserido. Limitar o acesso ao conhecimento historicamente construído pela humanidade alegando a pouca idade das crianças é apenas um mito que permeia o ambiente educacional.

É preciso planejar, agir com intencionalidade e atender as necessidades impostas pela fase de desenvolvimento para se obter sucesso no processo de ensino e aprendizagem. E foi nessa 
perspectiva que alcançamos uma formação efetiva e de qualidade para aquelas crianças a partir do tema gerador "Bioma Cerrado" no ano de 2017.

Envolver as crianças em algo em que elas já estão inseridas em seu ambiente e que podem se reconhecer como parte pertencente da totalidade, promove o envolvimento e a compreensão das ações que estão sendo realizadas. Sendo assim, desenvolver os conteúdos previstos no currículo a partir do bioma ao qual se pertence, traz de forma significativa a aprendizagem.

$\mathrm{Na}$ expectativa de que este relato possa contribuir para reflexão de outros educadores e, com a certeza de que a aprendizagem e a visão crítica da totalidade acompanharão esses alunos, permaneceremos no processo de transmissão intencional e planejada de conhecimentos para todos aqueles que nos forem confiados.

\section{REFERÊNCIAS}

ARCE, A.; SILVA, D. A. S. M.; VAROTTO. Ensinando Ciências na Educação Infantil. Campinas: Alínea, 2011. BONDIOLI, Anna Maria. Gioco e educazione. Milano, Italia: Franco Angeli, 2002.

DOLZ, J.; SCHNEUWLY, B. Gêneros orais e escritos na escola. Campinas: Mercado de Letras, 2007

EHRENBERG, M. C. A linguagem da cultura corporal sob o olhar de professores da educação infantil. Pro-Posições [online]. 2014, vol.25, n.1, pp.181-198. ISSN 1980-6248. https://doi.org/10.1590/S010373072014000100010. 
NASCIMENTO, Maria Letícia B. Pode-se pensar a creche como espaço de conquista social? Algumas reflexões. In: CONGRESSO LUSO-AFRO-BRASILEIRO DE CIÊNCIAS SOCIAIS, 8., set. 2004, Coimbra.

OLIVEIRA-FORMOSINHO, J. O desenvolvimento profissional das educadoras de infância: entre os saberes e os afectos, entre a sala e o mundo. In: MACHADO, A. L. de A. (org.). Encontros e desencontros em Educação Infantil. São Paulo: Cortez, 2002

OSTETTO, Luciana Esmeralda (Org). Planejamento na educação infantil mais que a atividade, a criança em foco. In: OSTETTO, Luciana Esmeralda (Org.). Encontros e encantamentos na educação infantil: partilhando experiências de estágios. Campinas: Papirus, 2000. p. 175-200.

PASQUALINI, J. C.; TSUHAKO, Y. N. Proposta pedagógica para a Educação Infantil do Sistema 136 Municipal de Ensino de Bauru/SP [recurso eletrônico], orgs. Bauru: Secretaria Municipal de Educação, 2016.

ROCHA, Eloisa Acires Candal. Por que ouvir as crianças? Algumas questões para um debate científico multidisciplinar. In: CRUZ, S. H. V. A criança fala: a escuta das crianças em pesquisa. CRUZ, S. H. V. (org.). São Paulo: Cortez, 2008.

SANTOS, C. S. dos. Ensino de Ciências: abordagem histórico-crítica. Campinas: Armazém do Ipê (Autores Associados), 2012.

SARMENTO, Manuel Jacinto. Gerações e alteridade: interrogações a partir da sociologia da infância. In: Educação \& Sociedade, Campinas, v. 26, n. 91, ago. 2005. p. 361-378.

SAVIANI, Dermeval. (2015). Sobre a natureza e especificidade da educação. Germinal: Marxismo e Educação em Debate. 7. 286. 10.9771/gmed.v7i1.13575. 


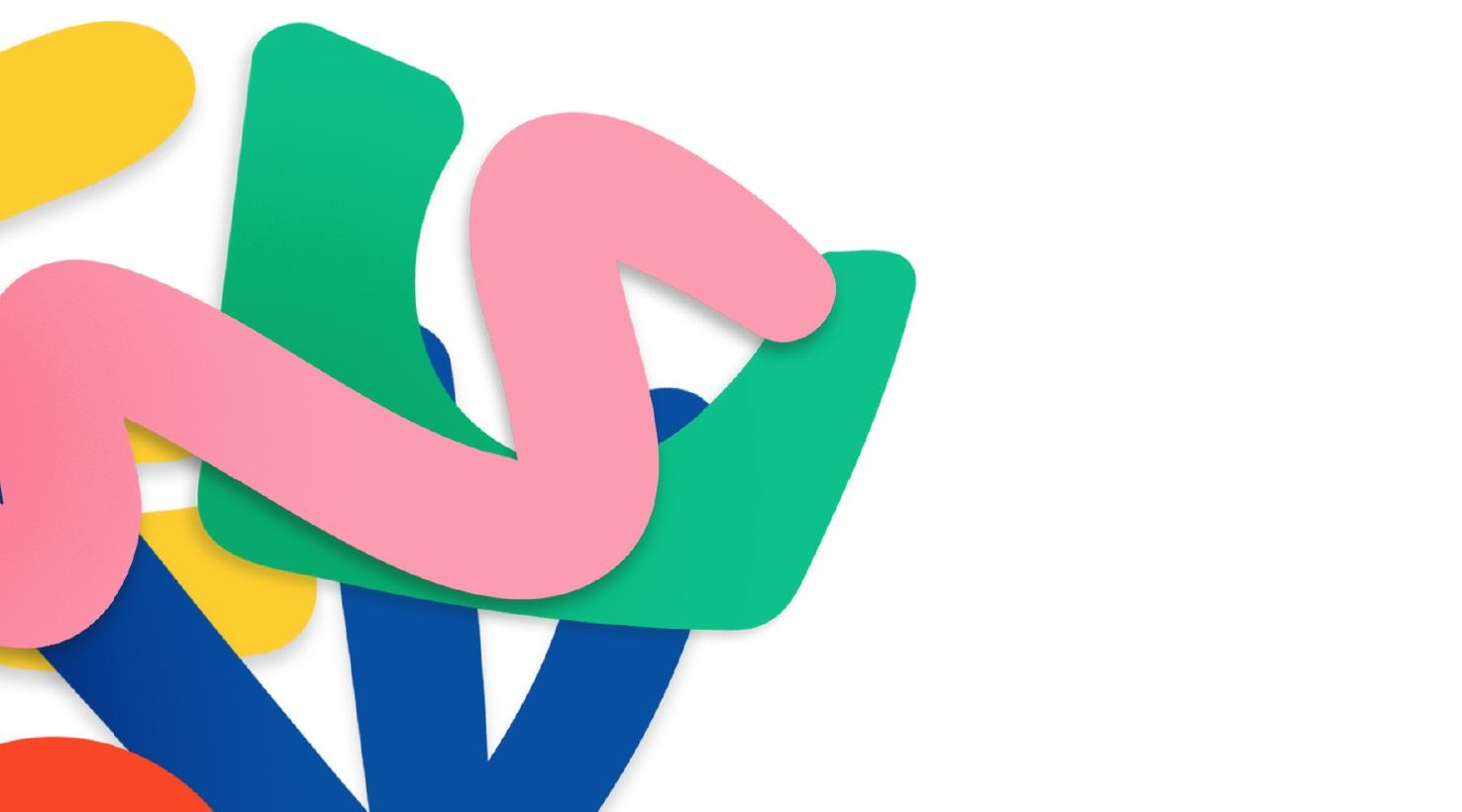




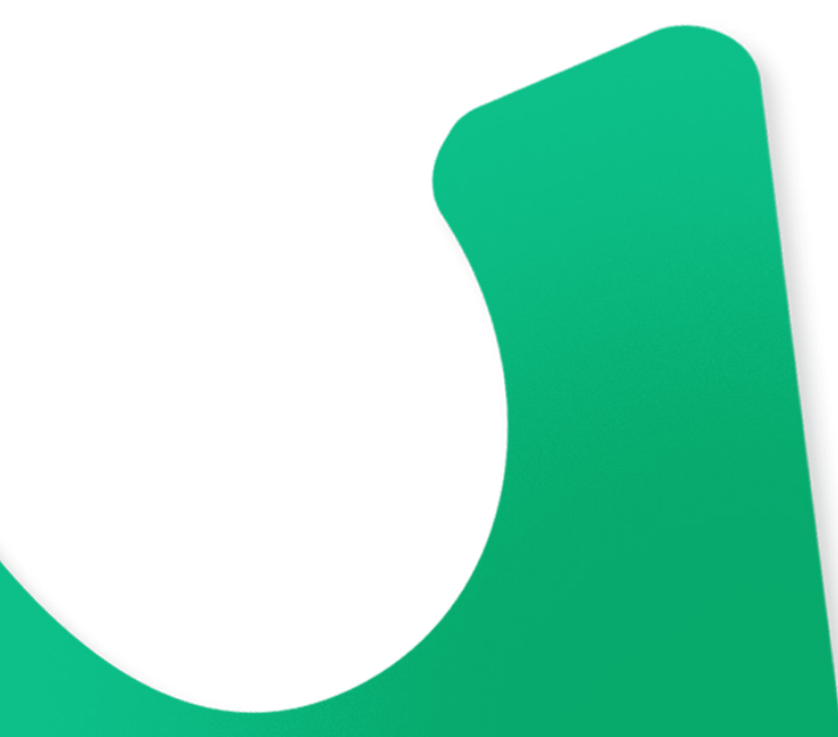




\section{DANÇA NA EDUCAÇÃO INFANTIL, UM MOVIMENTO POSSÍVEL}

Simone Aparecida Ferreira Tuler Xavier Bruna Di Richelle Souza Padovini

\section{INTRODUÇÃO}

O Conceito de Cultura Corporal é um termo relativamente recente, bem como sua importância e função no ambiente escolar. Realizamos um estudo histórico das transformações referentes ao conceito de Corpo e Corporeidade, relação social do corpo, o corpo como comunicação, as intervenções da ciência sobre o corpo, corpo "biológico e cultural", a educação do corpo como método disciplinar, entre outros.

Nos debruçamos neste trabalho a refletir sobre a importância da Corporeidade e da Cultura Corporal no desenvolvimento humano e o que está sendo proposto às crianças da Educação Infantil com relação a essa temática.

Dentre as várias atividades corporais na Educação Infantil está a Dança. É fato que nessa etapa da educação praticamente não há a presença de profissionais especificamente para as áreas de Artes e/ou Educação Física. Nessa direção, quais as possibilidades para se trabalhar a Dança na escola da pequena infância?

A criança necessita de movimento para expressar seus desejos e necessidades mais corriqueiras e 
simples. As atividades ritmadas da cultura corporal as estimulam, divertem e causam grande motivação lúdica, logo, as crianças gostam e participam com naturalidade dessa linguagem.

Dessa maneira, percebemos como é importante o trabalho com o movimento corporal já desde a Educação Infantil. Outrossim, para a realização de movimento necessitamos de um corpo e precisamos compreender nossa relação com esse corpo, que é biológico, é social e tem emoções e sentimentos. A escola é um dos lugares em que, de forma intencional, podemos propiciar situações para que essa relação entre corpo e movimento se desenvolva de forma eficaz.

Cultura Corporal e a Educação Infantil

Ao longo da história, com a evolução do conceito de Corporeidade e o surgimento da ideia de Cultura Corporal, vimos o quanto a sociedade influenciou e influencia no modo de ver o corpo e de pensar a relação desse corpo, principalmente, conforme o momento social em que estamos inseridos. Partindo do princípio onde o corpo era algo sagrado, Nobrega (2005, p.601) descreve que "essa linguagem do corpo está circunscrita ao privado, ao íntimo, ao secreto, ao inconfessável". Assim, literalmente, está ligada a algo que deve ficar reservado, muitas vezes ligada a religiosidade e ao profano, a impureza e a imoralidade, até o ponto onde o corpo passa a ser instrumento de manifestação da liberdade, 
a exposição do mesmo passa a ter o poder de confrontar determinadas crenças.

A indústria passa a perceber as mudanças de paradigma e a investir na "exploração" desse corpo criando uma infinidade de produtos e serviços para ele, que mesmo ao passar por mudanças ao longo do tempo, possui hoje uma gama de investimento em artigos para satisfazer a sua necessidade, sejam elas físicas, emocionais ou sociais.

Em tempo, todas essas situações permeiam o ambiente escolar, como lidar com todas essas situações na escola? Como propiciar um ambiente acolhedor a todos os corpos em sua diversidade e particularidades reunidos num espaço para a promoção da aprendizagem, tendo em vista que, "a escola é o primeiro espaço formal, onde se dá o desenvolvimento do cidadão" (LEÃO, 1991, p.01).

Estreitando a temática para a Educação Infantil, propiciar desenvolvimento global a corpos tão pequenos, não trabalhando somente as questões biológicas, mas um corpo que sente, que se expressa, que tem dificuldades, necessidades básicas e especiais é um desafio; faz-se necessário, portanto, a valorização do desenvolvimento corporal, cognitivo, emocional, social entre outras e fazer valer um direito das crianças que é o acesso à Educação Infantil.

A Educação Infantil atualmente é considerada um direito da criança, de acordo com a Constituição: 
A escola de Educação Infantil é um direito da criança constituído por lei, garantido pela Constituição da República Federativa do Brasil de 1988 [...] assistência gratuita aos filhos e dependentes desde o nascimento até seis anos de idade, em creches e préescolas" (BRASIL, 1988, p. 18-19).

A escola de Educação Infantil além de um direito, é espaço para interações entre professores e direção, professores e professores, professores e alunos, alunos e alunos, entre outros. Esta troca gera diferentes formas de se comunicar e expressar, visto que, cada ser humano é único e diferente. $\mathrm{Na}$ Educação Infantil, trabalhando com crianças de 0 a 5 anos, conseguimos visualizar esse processo 142 de desenvolvimento mediante as interações, que acontecem por meio das diferentes linguagens como gestos, balbucios, brincadeiras, palavras, bem como através de movimentos. Assim acreditamos de forma significativa no trabalho com o corpo, com o movimento, com o desenvolvimento da cultura corporal principalmente através da dança.

"Pela linguagem do corpo, você diz muitas coisas aos outros. E eles têm muitas coisas a dizer para você. Também nosso corpo é antes de tudo um centro de informações para nós mesmos". (WEIL; TOMPAKOW. 2004, p.7). Observando a citação acima entendemos a importância do trabalho com a Cultura Corporal, pois através do corpo e da sua linguagem podemos nos comunicar com o outro e conosco mesmo. 
O desenvolvimento cognitivo perpassa pela experiência corporal. Processos sensórios motores, percepção e ação são essencialmente inseparáveis da cognição. Assim precisamos refletir qual o lugar do corpo na Educação.

Pensar o lugar do corpo na educação em geral e na escola em particular é inicialmente compreender que o corpo não é um instrumento das práticas educativas, portanto as produções humanas são possíveis pelo fato de sermos corpo. Ler, escrever, contar, narrar, dançar, jogar são produções do sujeito humano que é corpo. Desse modo, precisamos avançar para além do aspecto da instrumentalidade. O desafio está em considerar que o corpo não é instrumento para as aulas de educação física ou de artes, ou ainda um conjunto de órgãos, sistemas ou o objeto de programas de promoção da saúde ou lazer. (NÓBREGA, 2005, p. 610).

Pensando em crianças, mais especificamente de 0 a 5 anos de idade, ou seja, as que estão hoje presentes nas escolas de Educação Infantil entende-se que estas se encontram num processo de conhecimento do seu corpo. Observamos assim, a importância de se realizar um trabalho de construção da consciência corporal nessa faixa etária, visto que, as crianças estão nesse processo de autoconhecimento e intenso desenvolvimento.

Estudos realizados por Laban (1953); Fúx (1983); Marques (2007) entre outros relacionados à 
dança-educação tratam dos benefícios e métodos de dançar, que ajudam e incentivam a prática da expressão e da comunicação, que podem contribuir para o desenvolvimento de outras linguagens como: oral e escrita, desenho, música, canto, entre outras, tendo em vista que "dançar é vivenciar, é exprimir com o máximo de intensidade a emoção a relação do homem, com a natureza, com a sociedade, com o futuro, com seus deuses [...]". (NANNI apud FLINCHUM, 1986, p. 3).

Possibilitar a criança o contato com a dança pode contribuir de forma significativa no processo de ensino aprendizagem, porquanto, a criança começa a explorar o ambiente onde está inserida a partir do seu corpo e do conhecimento do seu 144 corpo. Dançar proporcionará a ela um sentimento de liberdade de expressão e de gestos motivados por uma música, percebemos isso de forma clara quando colocamos uma música para um bebê ouvir e este, de forma voluntária ou não, começa a se mexer, iniciando o movimento do seu corpo.

A proposta de utilizar a dança no trabalho de desenvolvimento da consciência corporal das crianças baseia-se na ideia de que o movimento faz parte do cotidiano de sua rotina, principalmente na Educação Infantil. "Quando somos crianças necessitamos mover-nos porque movendo-nos expressamos nossa vontade de rir, chorar ou de brincar". (FÚX, 1983, p. 69).

Trata-se de ampliar uma linguagem que a criança já vivencia, além de estimular o conhecimento 
do próprio corpo e a prática da dança de forma prazerosa. Além disso, ensinar e aprender tornase mais atrativo e divertido quando se instiga o interesse das crianças e se "dá vida" ao conteúdo a ser trabalhado na escola.

\section{Dança e Formação de Professores}

Trataremos aqui da discussão sobre a atuação do Pedagogo com as diversas formas de trabalhar a Cultura Corporal, principalmente a Dança na Educação Infantil. “Aimportância daarte na educação geral e escolar é devida a função indispensável que a arte ocupa na vida das pessoas e na sociedade desde os primórdios da civilização, o que a torna um dos fatores essenciais de humanização" (FERRAZ; FUSARI, 2004, p.16). Desse modo, observamos que a arte, a música, a dança e o movimento já fazem parte da vida do ser humano.

Segundo Minidicionário da Língua Portuguesa (Bueno, 2000) a palavra dança significa: baile e divertimento, já a palavra educação significa instrução e ensino. Associando o significado das duas palavras temos um ensino divertido, do mesmo modo, dança-educação, assim, utilizar a dança na Educação Infantil como instrumento de aprendizagem e de desenvolvimento da criança permite aos educadores uma oportunidade de ensino sem perder o caráter lúdico. Logo, a diversão e o brincar fazem parte do dia a dia das crianças, podemos educar dançando ou dançar educando, pois "o homem através da dança, assume sua 
plenitude humana na vivência de sua instância lúdica". (NANNI, 2003, p. V).

O lúdico faz parte da vida do ser humano, assim, tudo aquilo que é trabalhado de forma lúdica desperta um interesse maior, particularmente das crianças. Trazer a dança para o ambiente escolar visando objetivos educacionais colabora os educadores a estimularem a aprendizagem e o desenvolvimento da consciência corporal de seus alunos, e também, é uma forma de observar como interagem, se expressam e se relacionam.

Vemos a dança com enorme potencial sócio cultural e educativo, podendo ser utilizada de formas diferentes nas escolas, sobretudo, avançando num trabalho de movimento corporal fundamentado 146 em teorias pedagógicas e de desenvolvimento infantil, visando a educação das crianças, a sua expressão, comunicação, seu desenvolvimento integral, ou seja, tanto nos aspectos físicos, quanto psicológicos e socioculturais.

Entretanto, para isto, se faz necessário que a formação do pedagogo que irá lidar com esta arte nas escolas seja efetiva. Educadores que tem a responsabilidade de trabalhar com crianças da Educação Infantil devem estar bem preparados para lidar coma questão da corporeidade, do movimento, e da cultura corporal. A dança, por sua vez, passa a ser um instrumento para que eles desenvolvam a sensibilidade tornando aprendizagem significativa para seus alunos. Assim percebemos a importância dos cursos de Licenciatura em Pedagogia em 
preparar bem seus estudantes, em disciplinas relacionadas ao movimento corporal e, para aqueles que não tiveram essa oportunidade, a busca por formação continuada faz um importante papel na complementação dessa formação inicial.

Como educadores isso perpassa por nossas experiências a respeito do conceito de corpo, conhecimento do sujeito em si, a apropriação do mundo pelo corpo e aprender a partir do movimento. O Corpo - sensações e percepções em relação a nós mesmos e ao outro. Quais momentos têm "destinados" ao corpo, qual enfoque está presente a todo o momento. Como afirma Nóbrega, "nosso corpo traduz marcas sociais e históricas, portanto questões culturais, questões de gênero, de pertencimentos sociais podem ser lidas no corpo" (2005, p. 610). Por isso a importância de buscar conhecimento para propiciar aos nossos alunos condições igualitárias de desenvolvimento, neste caso principalmente relacionado ao corpo, a dança e "não se trata de incluir o corpo na educação. Pensar o lugar do corpo na Educação significa evidenciar o desafio de nos percebermos como seres corporais" (NÓBREGA, 2005, p.610).

Culturalmente o que se observa é a Dança na Educação Infantil sem o caráter de um trabalho corporal significativo, mas voltado a aspectos recreativos. Isso se dá, sobretudo principalmente em virtude da formação do pedagogo.

Para que este conceito acerca da intencionalidade do trabalho envolvendo a dança, é necessário 
qualificar o profissional que irá desenvolver tais atividadesemsuarotina escolar, nocaso daEducação Infantil, o pedagogo. Pois para Fúx (1983), "a dança pode contribuir significativamente para a educação das crianças quando promove o desenvolvimento e a melhoria da natureza sócio emocional e afetiva do ser humano", instigando-o a cooperação, solidariedade, liderança, compreensão, apego; desenvolvendo ações cognitivas, o raciocínio, a atenção, a concentração, a criatividade, o senso estético que propicia a qualidade de vida, o desenvolvimento da consciência corporal, a auto expressão e o estímulo a criticidade.

É importante que eles tenham visão de como trabalhar conceitos da Cultura Corporal para uma 148 criança nesta faixa etária, quais suas características e possibilidades nesta área, mas para isso é importante trabalhar a própria corporeidade, o próprio entendimento sobre isso.

Principalmente a falta de disciplinas relacionadas a Arte e ao Movimento já na graduação, fazem com esses profissionais formados em Pedagogia apresentem algumas dificuldades em lidar com atividades relacionadas a Cultura Corporal e a Dança mais especificamente.

A importância de preparar bem principalmente os professores e auxiliares destas escolas para o desenvolvimento do trabalho com a Cultura Corporal e a Dança se justifica por essa área envolver o movimento corporal na educação 
como linguagem da criança, além de tudo que já observamos ao longo deste estudo.

A escola da pequena infância, ao proporcionar o desenvolvimento infantil nas suas diversas dimensões, realiza a mediação entre a criança e o conhecimento culturalmente construído e traduzido em diferentes formas de linguagem (oral, corporal, musical, gráfico-pictórica e plástica). Ao mesmo tempo, as atividades desenvolvidas nesse tipo de escola desenvolvem na criança habilidade para expressão e comunicação. (GARANHANI; NALDONY, 2011, p. 65)

Habilidades essas que contribuem para a formação humana, no desenvolvimento amplo dos diversos tipos de linguagem e isso ocorre principalmente por meio das experiências que trazemos ao longo de nossas vidas, as quais também envolvem o nosso corpo.

"A experiência do corpo, é descobrir o ritmo interno através do qual se pode mobilizar a via de comunicação que há em seu interior. Para isso, o corpo deve ser motivado, e, sobretudo, ter um sentido: porque me movo e para quê?" (FÚX, 1983, p. 37).

Para trabalhar esses conceitos e responder tais questões precisamos ter nas escolas professores habilitados para trabalhar com esse tipo de atividades, uma maneira de conseguirmos habilitar esses professores é por meio da Formação 
Continuada, tão importante e necessária a todos os profissionais da área de Educação, pois lidamos com o desenvolvimento humano, formação de valores e habilidades que estão em constante movimento.

Além da formação em nível de graduação há de se considerar a necessidade da formação continuada que é uma maneira dos professores prosseguirem na construção do conhecimento e renovar seus saberes, e assim se manterem em constante processo de transformação e aprimoramento profissional. (FERREIRA, 2010, p. 26)

Este é o relato da experiência de elaboração e execução de um Projeto de festa junina "Tudo é 150 Brasil" de uma Escola Municipal de Educação Infantil Integrada- EMEll do município de Bauru, durante os meses de maio e junho de 2017 realizado de forma transdisciplinar com as áreas do conhecimento: linguagem oral e escrita, matemática, ciências da natureza, ciências da sociedade, artes visuais, música e a cultura corporal de movimento. Esta vivência foi realizada com a turma infantil IV e V com crianças em idade entre 4 e 5 anos em um grupo de 21 crianças, que frequentavam a escola em período integral.

Baseado no livro "Tudo é Brasil" de Beatriz Monteiro da Cunha (2002) onde ela aborda a pluralidade cultural de nosso país devido a diversidade de atividades e costumes, isto é, apesar das tradições ditas brasileiras, cada região 
do Brasil tem suas particularidades: expressões verbais, roupas, artesanatos, festas, músicas, danças, comidas, literatura entre outras coisas.

Aproveitando o ensejo de no mês de junho acontecer no Brasil, as festas juninas o projeto "Tudo é Brasil" tinha como proposta fazer uma abordagem desta festa como cultura brasileira, dando enfoque a esta diversidade de atividades e costumes, culminando na apresentação aos pais de uma dança típica. Como forma de organizar o trabalho, as turmas foram divididas em cinco regiões brasileiras, assim como as ideias de Darcy Ribeiro, citadas por Schiling (2014): Brasil Crioulo (Nordeste), Brasil Sertanejo (Centro-Oeste), Brasil Caboclo (Norte), Brasil Caipira (Sudeste) e Brasil Sulino (Sul) abordando aspectos culturais de cada região, seus costumes, músicas, danças, lendas e tradições.

O objetivo desta prática pedagógica foi proporcionar as crianças conhecer e valorizar as manifestações folclóricas e a diversidade cultural brasileira, através da "transmissão de conhecimentos científicos, artísticos e filosóficos por meio de uma prática orientada por fins determinados de forma intencional e consciente" (PASQUALINI;TSUHAKO, 2016), de maneira que eles vivenciassem momentos da cultura das regiões brasileiras, ao longo de dois meses de trabalho e através de sequencias didáticas passassem a conhecer e valorizar esta cultura, reconhecendo sua importância como patrimônio cultural brasileiro na formação de nossa identidade. 
O objetivo específico do trabalho na apresentação de Dança na área de Cultura Corporal é "ampliar as possibilidades de domínio consciente e voluntário das ações corporais de natureza lúdica, artística e de destreza por meio da apropriação de atividades da cultura corporal: as brincadeiras de jogo, de dança e de ginástica, entre outras" (PASQUALINI; TSUHAKO, 2016).

Desta forma, com o propósito de ampliar o repertório de conhecimento de nossas crianças na educação infantil e propiciar vivencias a respeito de quem somos nós: o povo brasileiro, nossa mistura de raças, tradições, costumes entre outros, propusemos uma sequência didática da região Nordeste, o Brasil Crioulo focada nas principais 152 características desta região, despertando o interesse e a curiosidade das crianças pelo contexto histórico e social deste povo, valorizando nossa cultura e nossas práticas, enfim nossas raízes.

A primeira atividade com as crianças foi uma roda de conversa, para situá-las sobre as Regiões do Brasil, que é o país onde moramos e que ele é composto por essas regiões, que são formadas por estados onde estão inseridas as cidades onde moramos, como por exemplo, Bauru, faz parte do Estado de São Paulo, que compõe a Região Sudeste do Brasil. Tudo isso explorado através de mapas: mapa mundi, mapa do Brasil e o globo terrestre para mostrar que o Brasil também é um pedacinho do planeta Terra e que existem outros países. Esta atividade foi realizada aos poucos aprofundando a 
cada dia o tema. Desta roda de conversa elegemos nossa região: Nordeste, o Brasil Crioulo.

Realizamos ao longo das semanas a leitura na integra do livro: "Tudo é Brasil", sendo em cada dia a leitura de um tópico do livro, contando a História do Brasil, o início de tudo com os índios, a chegada dos portugueses e dos negros, conhecendo um pouco da miscigenação do Brasil, então passamos a leitura de cada uma das regiões aprendendo um pouco da cultura e das principais características de cada região.

Assistimos a um documentário sobre as principais características da região Nordeste onde conhecemos um pouco da história de Lampião e Maria Bonita, personagens importantes da Região.

Depois iniciamos uma pesquisa sobre características específicas da região Nordeste, como as frutas e comidas típicas, animais, músicas, personagens importantes, palavras e expressões, brincadeiras, instrumentos musicais, leitura de cordel, danças entre outras curiosidades da cultura nordestina. Desta pesquisa elegemos a Dança que apresentaríamos aos pais, assim escolhemos o Frevo.

A partir de então, iniciamos a busca por uma música que representasse o frevo nordestino, conhecemos Asa Branca e Xote das Meninas (Luiz Gonzaga) e Banho de Cheiro de Elba Ramalho e as crianças se encantaram com um vídeo de Frevo com esta música, muito alegre, animado e colorido o frevo contagiou nossas crianças. 
Trabalhamos a palavra frevo, o que é o frevo, o símbolo característico que representa o frevo: guarda - chuva e suas cores. Realizamos a leitura da letra da música Banho de Cheiro e a parte mais prazerosa para as crianças foi dançar, pois "quando somos crianças necessitamos mover-nos porque movendo-nos expressamos nossa vontade de rir, chorar ou de brincar". (FÚX, 1983, p. 69).

Figura 1: grupo de crianças que participaram do projeto

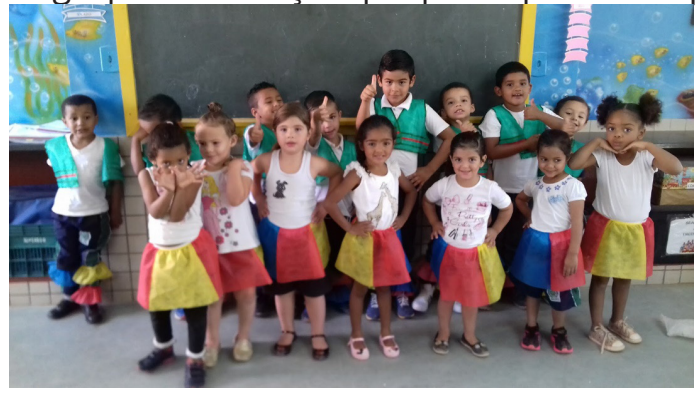

Fonte: Arquivo pessoal

O primeiro contato com a música foi livre, deixamos as crianças se movimentarem ao som da música de forma espontânea, expressando suas emoções e sentimentos ao som da música. A partir daí, assistimos novamente a um vídeo de frevo e pedimos as crianças para observar os passos, movimentos e a então, construímos juntos alguns movimentos elaborando uma coreografia para apresentar aos pais no dia da Festa Junina. As crianças reproduziram com o corpo movimentos circulares, saltos, equilíbrio num pé só e assim fomos encaixando os movimentos na sequência 
e inserido alguns passos em dupla, movimentos desafiadores como o agachamento e a vivência com o guarda-chuva de frevo, que não podia faltar. Assim com o passar dos dias e dos ensaios ao se apropriarem dos movimentos a "brincadeira" de dançar ia ficando mais divertida, trabalhamos diversos conceitos da Cultura corporal de movimento através do lúdico.

Nós também não tínhamos todo o conhecimento e habilidade necessários para a execução do Projeto, mas a vida do professor é esta de dia a dia buscar, pesquisar, estudar novos conceitos, novas formas e novos conteúdos para mediar junto a seus alunos a construção de conhecimento significativo de forma lúdica, divertida e prazerosa. Aprender brincando, dançando em nossa experiência fez toda a diferença.

Figura 2: interação entre professora e grupo de crianças

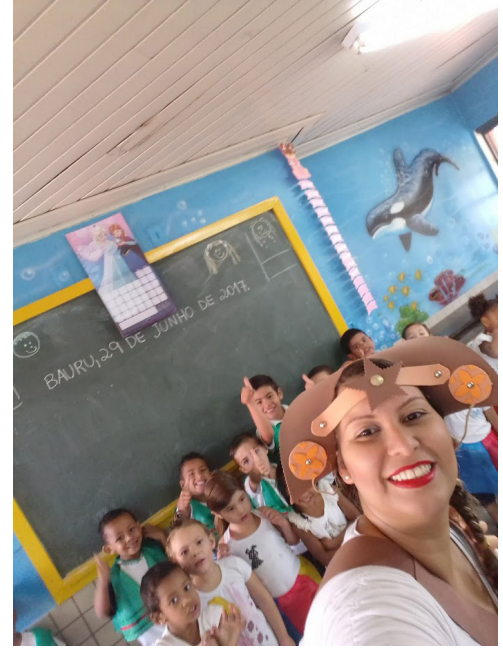

Fonte: arquivo pessoal 
Em princípio nosso olhar era apenas conhecer um pouco da região Nordeste e proporcionar aos pais momentos de acolhimento, carinho e aconchego ao serem convidados para assistirem a apresentação de seus filhos, mas nosso projeto e a nossa Dança se tornaram um grande instrumento de aprendizagem coletiva.

Semelhantemente, pudemos no decorrer dos meses interagir com a cultura nordestina, que é a cultura de nossos pais, avós, nossos ancestrais, muitos saíram do Nordeste para tentar uma nova vida em outras regiões. Poder resgatar essa cultura que é nossa, que é nossa história como brasileiros de forma tão prazerosa e divertida através do frevo proporcionou ampliação de repertório cultural não 156 só dos professores e crianças, como também dos pais, tornando a apresentação num processo de ensino-aprendizagem significativo.

Dessa forma, o estudo, a pesquisa e o conhecimento que envolveu o projeto ficará registrado na memória, no coração, na vida e construção da consciência corporal destas crianças, - que caracteriza o trabalho intencional de planejamento, estudo, formação continuada como forma de oportunizar uma educação significativa e de qualidade. Tornando, portanto, efetivo o papel da escola de sistematizar e proporcionar a apropriação do conhecimento elaborado historicamente pela humanidade, dando condições aos alunos de conhecer, experimentar vivencias 
e dialogar com conceitos que os farão cidadãos crítico e conscientes da realidade onde vivemos.

\section{Considerações Finais}

Observando a dificuldade dos educadores em lidar com atividades de expressão corporal e movimento levantou-se o questionamento sobre a temática do nosso estudo.

Após realização da pesquisa bibliográfica as leituras sobre a dança e suas contribuições para a educação e o ensino, observamos ainda mais a importância de se estudar esta problemática, principalmente na Educação Infantil, observando que as crianças estão numa fase importante de desenvolvimento e a dança pode contribuir de maneira significativa neste desenvolvimento, possibilitando às crianças aulas mais dinâmicas e lúdicas com a dança.

Porém para isso é necessário que o pedagogo esteja apto a lidar com atividades de Cultura Corporal: expressão, ritmo e Dança. Como a Dança pode contribuir na educação e quais as dificuldades que o pedagogo enfrenta para trabalhar com ela na Educação Infantil. Estudamos autores que abordam a importância da dança na escola e da arte-educação como método de ensino e suas contribuições para o ensino.

Foram levantados alguns apontamentos sobre a formação de professores, a importância de um trabalho unificado entre teoria e prática nos cursos 
de licenciatura para que os profissionais formados em cursos de Pedagogia possam ter suporte para aplicarem em sala de aula as teorias estudadas nos cursos de formação de professores.

Após nossos estudos refletimos que a principal dificuldade de atuação do pedagogo com a dança na Educação Infantil é relacionada à sua formação, pois faltam disciplinas especificas sobre a dança nos cursos de formação de professores de pedagogia, de maneira que estes cursos não proporcionam aos futuros profissionais, os conteúdose as metodologias para trabalhar com a dança na Educação Infantil. A estrutura dos cursos de pedagogia no Brasil ainda não está preparada para dispor de disciplinas especificas de arte-educação. Estudiosos da área 158 de arte-educação lutam para que atividades como a dança e o movimento sejam valorizados nas escolas, porém a maioria destes estudiosos é da área de artes (artes plásticas, desenho etc.) e não da área da educação, propriamente dita como alunos da pedagogia, por exemplo.

Neste capítulo procuramos destacar a formação do ser humano de forma integral, tentando evidenciar que vários aspectos são importantes e que nenhum deve ser desprezado, que o ser humano é um ser biológico, social e também um ser emocional, e a importância do conhecimento para que o educadores possam na prática oferecer um ensino de qualidade propiciando um ambiente escolar que favoreça o desenvolvimento integral do ser humano. 
Ao pensar a escola como um ambiente reflexivo e de construção de bases para que os alunos possam analisar criticamente a sociedade em que vivem, nesse caso especificamente sobre o seu próprio ser em desenvolvimento, só torna o papel da escola e do educador ainda mais essencial como mediador da construção desse conhecimento.

De maneira que dividir essa experiência de uma prática, um movimento possível com uma atividade envolvendo a Dança na escola engrandece nobremente a construção e a divulgação de atividades que realizamos no ambiente escolar.

Dessa forma, compartilhar este estudo com outros educadores contribui para a expansão das demais práticas da Cultura Corporal a Dança mais especificamente, nos fazendo compreender a importância de levar aos alunos diferentes formas de conhecer, mediar e refletir sobre as práticas construídas pela humanidade ao longo do tempo.

Consideramos que o objetivo foi alcançado, tendo em vista que o objetivo do estudo era o de pesquisar a Formação do Pedagogo para trabalhar com a Dança na Educação Infantil, embora o Pedagogo encontre dificuldades em trabalhar com a dança devido à diversos fatores, principalmente relacionados a formação, observamos que por meio de estudos, práticas realizadas e através da formação continuada esse trabalho se torna possível.

Assim concluímos que esta leitura tem muito a contribuir para o aprimoramento profissional 
de educadores e para a divulgação e estudo do conceito de Cultura Corporal, Educação do corpo, Movimento e o Desenvolvimento Humano, Dança e Arte de forma integral. Os conhecimentos adquiridos em nossas discussões muito agregaram para este estudo e para a busca de sempre contribuir com uma educação de qualidade.

\section{REFERÊNCIAS}

ABNT. Associação Brasileira de Normas Técnicas. NBR 10520: Rio de Janeiro, 1992.

BARBOSA, A. M. Arte-educação: conflitos e acertos. $3^{\text {a }}$ ed - São Paulo: Max Limonad, 1988.

BRASIL. Lei no 9394, de 20 de dezembro de 1996. Estabelece as diretrizes e bases da educação nacional. 160 Lei de Diretrizes e Bases da Educação Nacional. Brasília: Avercamp, 1996.

BUENO, S. Minidicionário da língua portuguesa. São Paulo: FTD, 2000.

CUNHA, Beatriz Monteiro da. Tudo é Brasil. São Paulo: Evoluir, 2002.

FERRAZ, M. H. C. T.; FUSARI, M. F. R. Metodologia do ensino da arte. 2. ed. São Paulo: Cortez, 2004.

FERREIRA, S. A. Dança na escola: um estudo sobre a formação do pedagogo para trabalhar com a Dança na Educação Infantil. Trabalho de Conclusão de Curso (TCC) - Licenciatura Plena em Pedagogia. Faculdade de Ciências. Universidade Estadual "Júlio de Mesquita Filho" - UNESP - BAURU- SP, P. 62, 2010.

FÚX, M. Dança, experiência de vida. São Paulo: Summus, 1983.

GARANHANI, Marynelma C.; NALDONY, Lorena de F. O movimento do Corpo Infantil: Uma linguagem 
da criança. In: Universidade Estadual Paulista - Unesp; Universidade Virtual do Estado de São Paulo - Univesp (Org.). Caderno de formação: Formação de Professores: Educação Infantil: princípios de fundamentos. São Paulo: Cultura Acadêmica, Unesp - Pró-Reitoria de Graduação, Univesp, 2011. p. 65-74 v. 3. (Coleção Caderno de Formação, v. 3, bloco 1, módulo 3, n. 8). 200p. ISBN 978-85-7983-133-1. Disponível em https://acervodigital. unesp.br/bitstream/123456789/447/1/01d14t04.pdf. Acesso em 15 maio 2020.

LABAN, R. Domínio do movimento. São Paulo: Summus, 1978.

LEÃO, R. M. A arte no espaço educativo. Disponível em: <www.caracol.imaginario.com/paragrafo_aberto/ rml_arteeduca.html>. Acesso em: 01 out. 2007.

MARQUES, I. Dançando na escola. São Paulo: Cortez, 2007.

NANNI, D. Dança-educação: pré escola à universidade. 4. ed. Rio de Janeiro: Sprint, 2003.

NOBREGA, Terezinha P. da. Qual o lugar do corpo na educação? Notas sobre conhecimento, processos cognitivos e currículo. Educ. Soc. [online]. 2005, vol.26, n.91, pp.599-615. ISSN 1678-4626. Disponível em https:// doi.org/10.1590/S0101-73302005000200015. Acesso em 15 maio 2020.

PASQUALINI, J. C.; TSUHAKO, Y. N. Proposta pedagógica para a Educação Infantil do Sistema Municipal de Ensino de Bauru/SP [recurso eletrônico], orgs. Bauru: Secretaria Municipal de Educação, 2016.

SCHILLING, Voltaire. Darcy Ribeiro e os brasileiros do Brasil. 2014. Disponível em: <https://www.terra. com.br/noticias/educacao/historia/darcy-ribeiro-e-osbrasileiros-do-brasil,f97327c27ac63410VgnVCM500000 9ccceb0aRCRD.html>. Acesso em: 28.03.2019. 
SETTE, K. F. F. M. e SILVA, L. F. R. A. A formação dos profissionais das Creches Conveniadas: Uma nova prática na Secretaria Municipal da Educação de Bauru. In: IX Congresso Estadual Paulista sobre Formação de Educadores, 2007, Águas de Lindóia SP. Congresso Estadual Paulista sobre Formação de Educadores, 2007. v. 9. p. 19-29.

WEIL, P; TOMPAKOW, R. O corpo fala. Petrópolis: Vozes, 2004. 


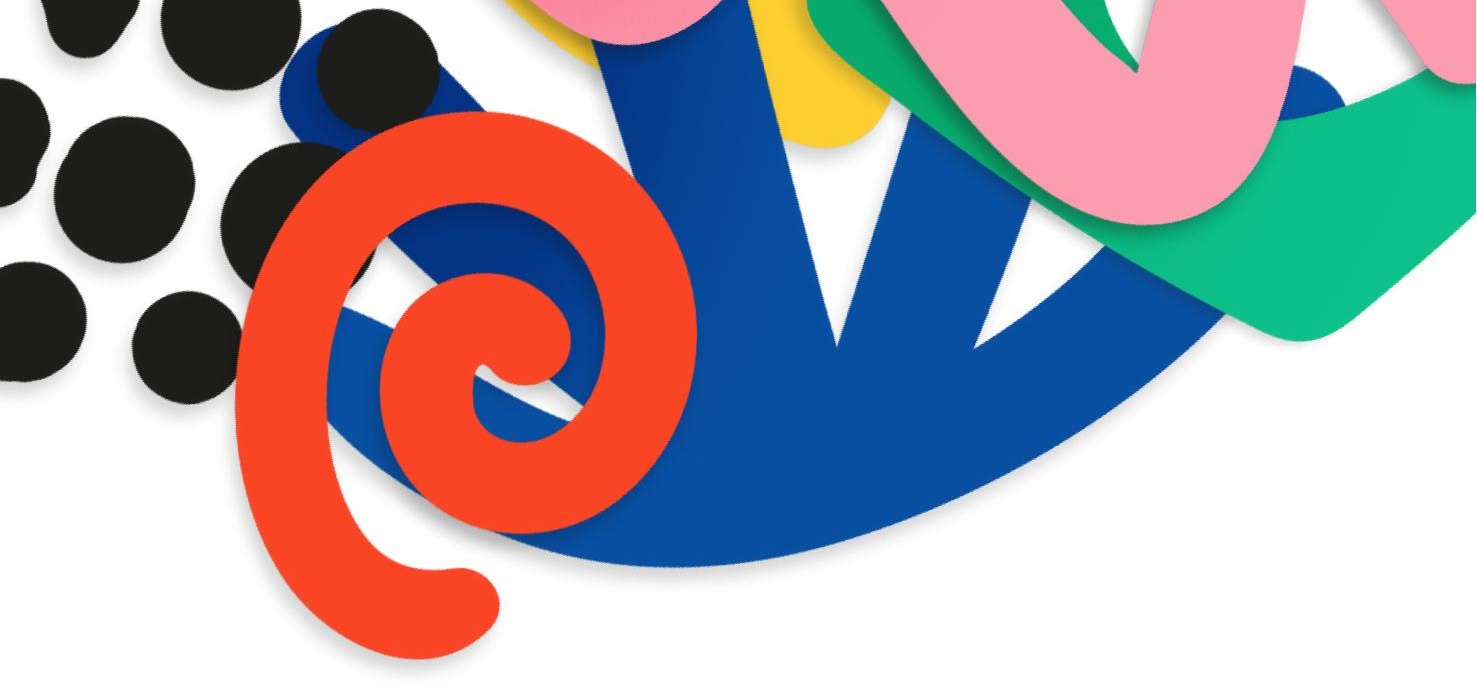



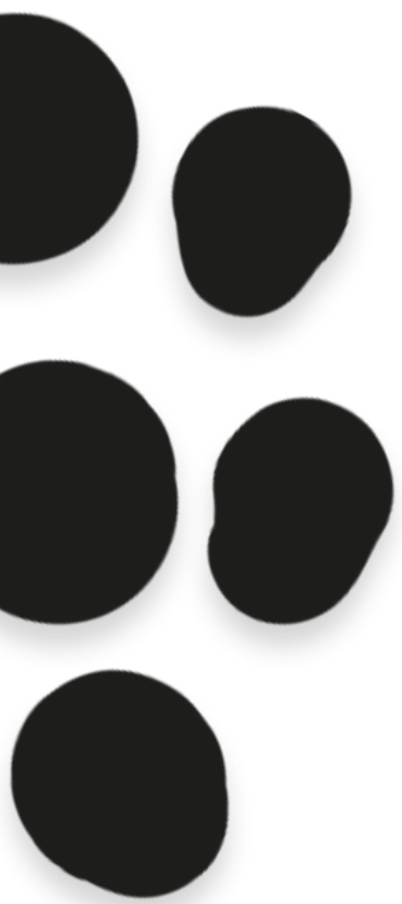


\section{ENCONTRO DE ENCANTOS: ARTE E EDUCAÇÃO INFANTIL}

Carita Pelição

Taís Pelição

\section{INTRODUÇÃo}

A humanidade é relativamente nova no Planeta Terra, sendo que o aparecimento dos primeiros hominídeos data de 3,5 milhões de anos atrás. Desde então, o Ser Humano mudou e se desenvolveu muito, no sentido de passar de um estágio muito primitivo e quase intuitivo, para um nível cognitivo mais avançado e que lhe permitiu criar técnicas e tecnologias em benefício próprio.

A história nos mostra que todo esse processo teve relação direta com a arte, sendo esta inerente ao Homem e, consequentemente, expressão própria da criança, que por sua vez, nem sempre teve lugar de destaque nas sociedades. Por muito tempo o Homem foi considerado superior em muitos aspectos e, principalmente, as crianças que eram vistas como seres ininteligíveis, incapazes de se comunicarem e de serem autônomos. Prova disso são pinturas da Idade Média (séculos $V$ e $X V)$, que nos revelam uma infância adultizada, representando o corpo infantil fora de proporção, com músculos e até grotescos.

Somente com a chegada Renascimento (meados do século XIV e XVII), e mais precisamente dos ideais 
Iluministas no século XVIII, que a infância passou a ser vista por uma perspectiva mais acolhedora, considerando, assim, suas especificidades. Desde o século XVIII até a modernidade, diversos estudiosos tiveram seus interesses voltados para a criança e, nessa direção, muito do desenvolvimento desta pôde ser sistematizado e se converge hoje em inúmeras diretrizes, resoluções, leis e concepções pedagógicas.

No entanto, mesmo diante de documentos atestando a necessidade da atenção à primeira infância, esta ainda sofre algumas negligências, seja no prisma pedagógico, seja familiar ou político. Com a pandemia de coronavírus, ocorrida com mais intensidade no ano de 2020, ficou evidente o quanto a educação infantil ainda carece de fortalecimento. Nesse período observou-se um distanciamento expressivo da infância lúdica e criativa. A criança, restrita ao perímetro de sua casa ou apartamento, teve seu brilho e vivacidade próprios, muitas vezes, direcionado para a realização de atividades adaptadas àquela realidade.

É verdade que os professores, escolas e secretarias de educação se reinventaram para suprirem as novas demandas sociais. No entanto, os estudos relacionados a esse contexto ainda estão em curso, sendo que os resultados e consequências destes serão divulgados e mensurados em um futuro próximo.

Vale ressaltar, porém, que devido ao panorama apresentado, a arte acabou tendo um papel 
coadjuvante para a primeira infância, exatamente pelas barreiras comunicacionais, sociais, políticas e tecnológicas expostas pela pandemia. Claro que esse secundarismo não foi uma regra e várias práticas foram exitosas e até mesmo reconhecidas através de prêmios, como por exemplo, oXXII Prêmio Arte na Escola Cidadã, do Instituto Arte na Escola. O fato, no entanto, é que a arte deve caminhar ao lado da educação infantil, independente das condições extremas pelas quais esta última passe.

Isto posto, este capítulo tem por objetivo enfatizar a importância da relação entre arte e educação infantil, seja no ensino remoto, híbrido ou presencial.

\section{Breve Contexto Histórico da InfÂncIa}

$\mathrm{Na}$ atualidade existem definições claras sobre a criança e o desenvolvimento infantil que são norteadas por documentos e diretrizes específicos. Conhece-se as diferenças entre o adulto e a criança e os devidos cuidados e precauções que se deve ter com ela. No entanto, essa concepção nem sempre foi claramente estabelecida e ao longo da história da humanidade, o conceito de infância passou por muitas transformações, sendo intricado, sinuoso e em alguns momentos, inexistente. Afinal, "ao falar-se (e ao estudar-se) as crianças, produzemse, na ordem do discurso e na ordem das políticas sociais, efeitos contraditórios, que resultam da extrema complexidade social da infância e da 
heterogeneidade das condições de vida" (PINTO; SARMENTO, 1997, p. 14).

Segundo Manuel Pinto:

A inexistência de um sentimento da infância em séculos passados, não significa necessariamente que as crianças fossem negligenciadas, desamparadas ou tratadas com desprezo. Uma coisa é a existência da ideia de infância e outra a de afeição pelas crianças. O que se passava era que, logo que a criança se mostrava capaz de viver sem a constante solicitude da mãe ou da ama e adquiria um certo grau de discernimento de si e do mundo, se ia incorporando gradualmente na sociedade adulta. A idadereferência para o início desta transição parece ter sido o perfazer dos sete anos, altura em que a Igreja, desde o $4^{\circ}$ Concílio de Latrão, em 1215, considerava atingido "algum uso da razão" e autorizava, por isso, a confissão e comunhão (PINTO; 1997, p. 35).

Pinto (1997) garante que, historicamente, existiu uma certa preocupação pedagógica relacionada à infância, mas sem, obrigatoriamente, implicar em uma categoria especial de idade. Para o autor, "nas civilizações clássicas encontramos sinais de uma valorização da educação, através do que se chamou, na Grécia, a paideia" (PINTO, 1997, p. 36). No entanto, quando o assunto é Idade Média (séculos V e XV), registra-se uma decaída pela sensibilidade educacional, mesmo porque "a escola medieval 
permaneceu indiferente à distinção e separação das idades, uma vez que não se destinava a educar a infância" (PINTO, 1997, p. 36). Andrade (2010) assevera que:

Na Idade Média, as crianças pequenas não tinham função social antes de trabalharem, sendo alta a taxa de mortalidade infantil. Aquelas que eram pobres, assim que cresciam eram inseridas no mundo do trabalho, sem qualquer diferenciação entre adultos e crianças. As crianças nobres tinham seus educadores e eram vistas como miniaturas dos adultos e deveriam ser educadas para o futuro de transição para a vida adulta (ANDRADE, 2010, p. 48-49).

Para compreender o porquê desse afastamento que o medievo demonstrou para com a infância, é necessário entender que naquele período a igreja católica exercia total domínio e queria impor seus dogmas como recurso de manter seus ideais vivos na sociedade. Diante de uma população majoritariamente analfabeta, o clero viu na arte uma forma de catequização. Assim, o controle da massa e a consequente produção de obras que retratassem passagens bíblicas se tornou prioridade.

O Papa Gregório, o Grande, que viveu no final do século VI D.C., seguiu essa orientação. Lembrou àqueles que eram contra todas as pinturas que muitos membros da Igreja 
não podiam ler nem escrever, e que, para ensiná-los, essas imagens eram tão úteis quanto os desenhos de um livro ilustrado para crianças. Disse ele: "A pintura pode fazer pelos analfabetos o que a escrita faz para os que sabem ler". Foi de uma importância imensa para a história da arte que uma tão grande autoridade tenha acudido em favor da pintura. Sua sentença seria repetidamente citada sempre que as pessoas atacavam o uso de imagens nas igrejas. Mas é claro que o tipo de arte que foi assim admitido era de uma espécie algo restrita. Para que o propósito expresso por Gregório I fosse servido, a história tinha que ser contada da maneira mais clara e simples possível, e tudo o que pudesse desviar a atenção dessa finalidade principal e sagrada deveria ser omitido. No começo, os artistas ainda usaram os métodos narrativos que tinham sido desenvolvidos pela arte romana, mas, gradualmente, passaram a concentrarse cada vez mais no que era estritamente essencial (GOMBRICH, 2000, p. 83).

Isto posto, reiteramos que até meados do fim do século XVII, a criança era vista como um adulto em miniatura e seus sentimentos e ideologias, bem como seus processos de desenvolvimento, não eram respeitados em detrimento de uma ideologia cristã que objetivava criar raízes no consciente das pessoas iletradas. Estas, por sua vez, eram doutrinadas através de obras de arte 
encomendadas diretamente pela igreja, que representavam a criança de modo descaracterizado. Tal concepção pode ser observada, por exemplo, na obra intitulada Madonna and Child, do pintor italiano Bono da Ferrara (século XV):

Figura 1: Madonna and Child, Bono da Ferrara (século XV)

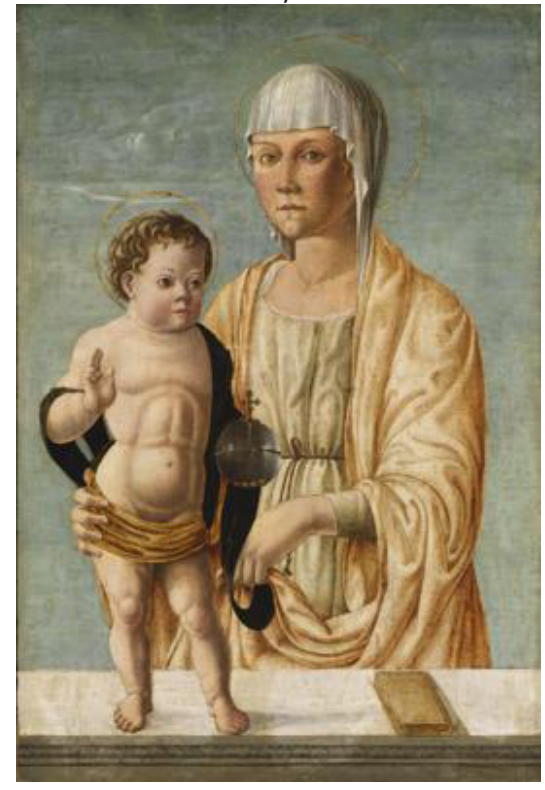

Fonte: Szépmüvészeti Múzeum

(Museu de Belas Artes de Budapeste, Hungria)

$\mathrm{Na}$ imagem, é possível notar que a criança se comporta como um adulto, possuindo, inclusive, postura ereta e firme, com seus músculos corporais bem definidos e gestos planejados. O único recurso que o artista utilizou para diferenciar o personagem infantil da mulher ao lado dele é a 
proporção reduzida, o que causa uma sensação de estranhamento para quem observa.

Contudo, Lins et. al. explica que "nos séculos $X V I$ e XVII existia uma consciência de que as percepções de uma criança eram diferentes das percepções dos adultos" (2014, p. 129), mas optava-se propositalmente pela representação adultizada exatamente pelo objetivo cristão das obras, que relacionavam as crianças ao imaginário que se tinha de Jesus, advindo da bíblia: como um homem perfeito.

Mas, já a partir do século XVIII, lentas transformações começaram a ser operadas no interior das famílias, ocasionando o surgimento do "sentimento de família", fortemente marcado pela necessidade e desejo de privacidade. Começaram a ocorrer mudanças até mesmo quanto ao espaço físico no qual a família vivia. [...] Instaura-se o modelo da família burguesa, o qual irá trocar a sociabilidade ampla pelo desejo de intimidade, reduzindo as vivências de formas comunitárias tradicionais. A intimidade e a vida privada da família moderna propõem novas relações familiares, acompanhadas por mudanças de valores, especialmente em relação à educação das crianças. A criança assume um lugar central na família, pois se antes era cuidada de forma difusa e dispersa pela comunidade em geral, passará a ser responsabilidade dos pais (ANDRADE, 2010, p. 49-50).

Se, portanto, no século XVII houve maior conscientização em relação à criança, o século XVIII 
foi um divisor de águas devido ao lluminismo que rompia com os preceitos religiosos em detrimento da razão, defendendo a compreensão do ser humano em todos os campos, o que fez mudar consideravelmente as relações que os adultos tinham com as crianças. Para Kobayashi:

A visão iluminista trouxe mudanças nas relações entre a criança e os adultos, que envolvem as formas como apresentamos o mundo a elas, seja na família, na escola ou na sociedade, e podem ser acompanhadas pela forma como evoluíram as teorias do desenvolvimento, ensino e aprendizagem e nos objetos direcionados ao mundo infantil, que conhecemos pelo nome de brinquedos, jogos, livros, vídeos, entre outros. Tais objetos são as formas que temos para apresentar e colocar a criança em relação ao mundo em que ela vive [...] (KOBAYASHI, 2019, p. 89).

\section{Ensino de Arte no Brasil}

O ensino de arte no Brasil passou por muitos percalços e ainda passa, uma vez que, a arte como ferramenta indispensável para a construção crítica do pensamento, é considerada muitas vezes de forma proposital, como um componente curricular secundário.

Em nosso país, vários foram os métodos utilizados para o ensino de arte, a maioria deles baseados em concepções de estudiosos estrangeiros, que nada ou muito pouco relacionavam-se à 
realidade de nossas crianças e adolescentes. Como exemplo, citamos o pedagogo norte-americano John Dewey, que teve grande importância no século XX, especificamente meados de 1920, mas que foi erroneamente interpretado por diversos professores, como Nereu Sampaio, "professor de desenho da Escola Normal do Rio de Janeiro, que, interpretando as ideias deweyanas a seu modo, preconizava a mera apreciação fenomênica e a produção de representações realísticas de objetos observados, sem considerar o valor da imaginação" (ANDRADE; CUNHA, 2016, p. 303).

Segundo Andrade e Cunha (2016), ainda na década de 1920, havia uma tendência sob a égide de uma perspectiva tecnicista e formalista que pretendia subordinar o indivíduo às ordenações do ambiente social, no intuito de produzir de maneira mais objetiva o avanço do país. Essa tendência fez formatar claramente o ensino de arte desde a infância, acarretando em atividades automatizadas em que a criança apenas pintava ou contornava incansavelmente desenhos estereotipados já prontos.

Somentecoma Semana da Arte Moderna, ocorrida em 1922, "os modelos de educação técnica voltada para o trabalho, com forte identificação ao estudo do desenho clássico e do desenho geométrico, começaram a ser contestados, passando a valorizar a expressão infantil" (SILVA, 2010, p. 96).

Depois, conforme aponta Silva (2010), no início dos anos 1930 começaram a ganhar espaço no 
Brasil escolas especializadas em artes para crianças e adolescentes (as chamadas "Escolinhas de Arte") e, mais recentemente, com a nova Lei de Diretrizes e Bases da Educação Nacional n 9.394/96 - LDB (BRASIL, 1996), foi extinta a Educação Artística, entrando em campo a disciplina Arte, reconhecida oficialmente como área de conhecimento (SILVA, 2010).

É importante destacar que a arte é uma valiosa aliada da expressão, do pensamento, da linguagem e da comunicação humana e, por isso mesmo, indispensável para a formação do indivíduo na educação infantil. Silva (2010) afirma que "o ensino de Arte aborda uma série de significações, tais como: o senso estético, a sensibilidade e a criatividade" e continua:

A arte propicia à criança expressar seus sentimentos e ideias, colocar a criatividade em prática, fazendo com que seu lado afetivo seja realçado. Tendo essa observação voltada para o âmbito escolar, vemos claramente como as artes visuais são essenciais na interação social da criança e como os professores podem desfrutar desse recurso para isso. Além de utilizar as artes visuais para trabalhar o afetivo e a interação social da criança, o professor pode utilizálas no auxílio da motricidade infantil que deve ser bem trabalhada desde a infância para que, futuramente, ela possa sentir a diferença desse recurso na sua vida pessoal, escolar e profissional (SILVA, 2010, p. 98). 
Épormeiodaartequeacriançatemaoportunidade de expressar suas primeiras impressões do mundo ao seu redor e as relações que nele estabelece. Por isso, a arte se faz fundamental na infância, pois:

Desempenha um papel potencialmente vital na educação das crianças. Desenhar, pintar ou construir constituem um processo complexo em que a criança reúne diversos elementos de sua experiência, para formar um novo e significativo todo. No processo de selecionar, interpretar e reformar esses elementos, a criança proporciona mais do que um quadro ou uma escultura; proporciona parte de si própria: como pensa, como sente e como vê. Para ela, a arte é atividade dinâmica e unificadora (LOWENFELD; BRITTAIN, 1970, p. 10).

Nesse aspecto, os artigos 58 e 59 do Estatuto da Criança e do Adolescente - ECA- Lei $n^{\circ}$ 8.069, de 13 de julho de 1990, deixam muito claro que os valores culturais e artísticos deverão ser respeitados, inclusive recebendo recursos para serem divulgados:

No processo educacional respeitar-se-ão os valores culturais, artísticos e históricos próprios do contexto social da criança e do adolescente, garantindo-se a estes a liberdade da criação e o acesso às fontes de cultura. / Os municípios, com apoio dos estados e da União, estimularão e facilitarão a destinação 
de recursos e espaços para programações culturais, esportivas e de lazer voltadas para a infância e a juventude. (BRASIL, 1990)

Ressalta-se ainda, que a própria Lei de Diretrizes e Bases da Educação Nacional - LDB, em seu artigo $1^{\circ}$ considera que a educação deve abranger as manifestações culturais; "a educação abrange os processos formativos que se desenvolvem na vida familiar, na convivência humana, no trabalho, nas instituições de ensino e pesquisa, nos movimentos sociais e organizações da sociedade civil e nas manifestações culturais" (BRASIL,1996). A arte sendo manifestação cultural é inerente ao Ser Humano e, consequentemente, à criança, logo, deve ser parte integrante da educação infantil.

\section{Considerações Finais}

Percorremos brevemente a construção histórica da criança e sua relação com a arte, e compreendemos que o conceito de infância passou por diversos percalços, sendo inconstante nas diferentes sociedades. Notamos também que durante a Idade Média, a preocupação pedagógica que existiu na Grécia com a paideia, deu lugar a uma infância marginalizada e adultizada, reforçada com obras de arte que caracterizavam a criança como um adulto em miniatura em detrimento dos ideais catequizadores da igreja católica.

Somente com a valorização dos valores familiares burgueses no Renascimento e mais fortemente dos 
preceitos humanistas pregados pelo lluminismo no século XVIII, foi que a infância passou a ser vista com maior atenção.

Hoje, a criança é devidamente reconhecida por leis e diretrizes que norteiam suas características, singularidades, especificidades e necessidades, que protegem-na e garantem seus direitos perante à sociedade. Direitos esses que incluem o contato direto com a arte e expressão cultural, permitindo seu desenvolvimento como um todo. Assim, a educação infantil deve ser palco principal para que a criança e arte caminhem lado a lado, em equilíbrio e sintonia, independente das condições adversas que possam intercorrer ao longo dessa etapa de ensino.

\section{REFERÊNCIAS}

ANDRADE, E. N. F.; CUNHA, M. V.. A contribuição de John Dewey ao ensino da arte no Brasil. Espacio, Tiempo y Educación, v. 3, n. 2, July-December 2016, pp. 301-319.

ANDRADE, L. B. P. Educação infantil: discurso, legislação e práticas institucionais. São Paulo: Editora UNESP; São Paulo: Cultura Acadêmica, 2010.

BRASIL. Lei de Diretrizes e Bases da Educação Nacional, 1996.

BRASIL. Lei ${ }^{\circ} 8.069$, de 13 de julho de 1990 - Estatuto da Criança e do Adolescente - ECA, 1990.

FERRARA, B. Madonna and Child. Final da década de 1450. In: Szépmüvészeti Múzeum (Museu de Belas Artes de Budapeste, Hungria). Disponível em: 
<https://www.szepmuveszeti.hu/mutargyak/mariagyermekevel-18/>. Acesso em: 28 de Jun. 2021.

GOMBRICH, E. H. A história da Arte [recurso digital]. - 16 ed. - LTC Editora, 2000. Disponível em: <https:// mega.nz/file/f9oWVYJQ\#edMUr7E35UAYt6fwgqby4d1x 9leEp-nEQ-IpGcLAgCY>. Acesso em: 28 de Jun. 2021.

KOBAYASHI, M. C. M. Linguagens da criança e formação docente: histórias e circularidade. Universidade Estadual Paulista "Júlio de Mesquita Filho", Bauru/SP, 2019.

LINS, B [et al]. A compreensão da infância como construção sócio-histórica. CES Psicología, vol. 7, núm. 2, julio-diciembre, 2014, pp. 126-137.

LOWENFELD, V.; BRITTAIN, W. L. Desenvolvimento da capacidade criadora. São Paulo: Mestre Jou, 1970.

PINTO, M. A infância como construção social. In: PINTO, M.; SARMENTO, M. J. (Org.). As crianças: contextos e identidades. Braga: Centro de Estudos da Criança da Universidade do Minho, 1997.

PINTO, M.; SARMENTO, M. J. (Org.). As crianças: contextos e identidades. Braga: Centro de Estudos da Criança da Universidade do Minho, 1997.

SILVA, E. A. [et al]. Fazendo arte para aprender: A importância das artes visuais no ato educativo. Pedagogia em ação, v.2, n.2, p. 1-117, nov. 2010. 


$$
w
$$




\title{
INTENCIONALIDADES AO PROPORCIONAR A ATIVIDADE PRINCIPAL DA INFÂNCIA: O BRINCAR
}

\author{
Fabiana Hortolani Sartori \\ Alessandra Salvador Costa Morijo \\ Alice Nicassio de Oliveira
}

INTRODUÇÃo

O brincar nos primeiros anos de vida é uma necessidade básica e um direito da criança, sendo esta, a sua atividade principal (KISHIMOTO, 2010).

Este capítulo tem a intenção de delinear aproximações entre o professor, a criança e o brincar na rotina da educação infantil. Nessa direção, serão apresentadas propostas intencionais de brincadeiras que contribuem para a prática educativa no cotidiano de professores e educadores, ampliando o conhecimento sobre o papel das brincadeiras no processo de formação da criança pequena.

Vivemos um tempo em que a infância não é vivida em sua totalidade, tendo em vista, que as crianças desde muito cedo são inseridas em creches e préescolas que apresentam concepções plurais sobre a criança e a educação, refletindo assim, na qualidade do brincar oportunizado na primeira infância.

Se pararmos um pouco e pensarmos em como vivíamos nossas infâncias, é certo que traríamos a memória doces lembranças, nos remetendo a 
momentos prazerosos de brincadeiras e interações com nossos irmãos, primos e vizinhos.

Hoje em dia, alguns fatores, tais como a falta de tempo dos pais, o consumismo e os avanços tecnológicos contribuem para que as crianças não tenham tempo livre para brincadeiras criativas, crescem sem saber brincar, perdendo parte importante de sua formação. Muitos brinquedos e brincadeiras populares do dia a dia foram substituídos por brinquedos eutensílios eletrônicos, impondo um distanciamento que colabora para a formação de pessoas com dificuldades nas interações sociais e aprendizagens.

Assim, ao pensar sobre a infância e a brincadeira como atividade que guia o desenvolvimento das 184 crianças, muitas são as possibilidades de práticas lúdicas que resgatam as brincadeiras tradicionais. Ademais, é uma oportunidade de trabalhar a socialização, a interação, expressão psíquica e sociológica das crianças.

O presente capítulo tem características de pesquisa-ação, fundamentada em Thiollent (1985, p.14):

[...] um tipo de pesquisa com base empírica que é concebida e realizada em estrita associação ou com a resolução de um problema coletivo e no qual os pesquisadores e participantes representativos da situação ou do problema estão envolvidos de modo cooperativo ou participativo. 


\section{Desenvolvimento}

Crianças brincam porque a brincadeira é sua atividade principal e é por meio desse ato, que elas alcançam o desenvolvimento psíquico, preparando o caminho para um novo e mais elevado nível de desenvolvimento.

Partindo do pressuposto de que a criança naturalmente brinca, é possível entender a escola como um ambiente de aprendizagem formal dissociado do brincar? De acordo com Moyles (2006 p.14).

Em algum lugar, bem lá no fundo de cada um de nós, parece haver um sentimento de que aquilo que não dói não vai nos fazer bem, tipo "tudo o que arde cura"! Portanto, algo como o brincar, com seus altos níveis de motivação e potencial divertimento, parece, de certa maneira, não ser apropriado em ambientes institucionais.

Sendo assim, proporcionar o brincar no contexto da escola deve ser visto como algo natural e necessário para uma aprendizagem mais elevada. Faz mais sentido para a criança aprender brincando, levando-se em conta o estágio de desenvolvimento particular de cada estudante, ampliando as possibilidades de descobertas e tornando a escola um ambiente agradável e interessante.

Ainda nesse sentido, Friedmann cita que (2012, p.162):

Pensar em trazer o brincar como protagonista da escola é um avanço para 
a educação, porque assim tomamos consciência da importância que ele tem para o desenvolvimento integral das crianças, descobrindo nele um meio de conhecêlas mais profundamente, a fim de adequar propostas lúdicas e preservar suas culturas.

Os documentos oficiais normativos da educação nacional reconhecem o brincar como um importante instrumento de aprendizagem. A Base Nacional Comum Curricular - BNCC estabelece como um dos direitos de aprendizagem e desenvolvimento na educação infantil, o brincar.

Brincar cotidianamente de diversas formas, em diferentes espaços e tempos, com diferentes parceiros (crianças e adultos), ampliando e diversificando seu acesso a produções culturais, seus conhecimentos, sua imaginação, sua criatividade, suas experiências emocionais, corporais, sensoriais, expressivas, cognitivas, sociais e relacionais (BRASIL, 2017, p.38).

Mas então, brincar na escola não seria coisa séria? Na concepção de muitos professores seria o correto, entretanto sabemos que não é verdade. Basta observar nossas crianças brincando para reconhecer a brincadeira como uma importante aliada a prática pedagógica. Para tanto, precisam estar inseridas em um ambiente devidamente planejado e apoiadas por um professor atento as 
suas necessidades e níveis de desenvolvimento. Nesse sentido Moyles cita que:

A maioria dos professores diz que considera valioso o brincar e que ele tem um lugar na sala de aula, mas a maioria também indica implicitamente, por suas atitudes, que este lugar não é tão importante, sendo secundário às atividades que eles dirigem e supervisionam. Porém, especialmente nas escolas de educação infantil, não existe nenhuma evidência de que este ensino direto promove uma aprendizagem real nas crianças, pois ele raramente parte de onde as crianças estão prontas para começar. (2002, p. 100).

Esse processo do brincar permite que a criança se desenvolva e crie novas possibilidades de aprendizagem. Na brincadeira de faz de conta ela tem a oportunidade de representar a realidade do mundo adulto, sendo um poderoso instrumento de desenvolvimento da imaginação, preparando-a para realidades da vida adulta, segundo Friedmann (2012, p. 41):

Vigotsky acredita ser a atividade lúdica crucial para o desenvolvimento cognitivo, pois o processo de criar situações imaginárias leva ao desenvolvimento do pensamento abstrato. Isso acontece porque novos relacionamentos entre significados, objetos e ações são criados durante o brincar. 
Sendo assim, devemos pensar no ato de brincar como um grande aliado da prática em sala de aula, proporcionando à criança aprendizagens mais completas, importantes para a formação do ser humano e sem cobranças desnecessárias para essa faixa etária.

Parte do trabalho do educador é refletir, selecionar, organizar, planejar, mediar e monitorar o conjunto das práticas e interações, garantindo a pluralidade de situações que promovam o desenvolvimento. Essa intencionalidade consiste na organização e proposição de experiências que permitam a interação social, experimentação que levará a muitas descobertas. Brincadeira para a criança é coisa séria, é por meio do brincar que ela aprende e se desenvolve de forma integral.

Cabe aos professores ter um olhar atento às necessidades dos alunos. Afinal, despertar o interesse desses pequenos pela aula não é tarefa fácil, levando em conta que eles estão em processo de descobertas e vivências que o mundo lhes oferece o tempo todo. O brincar, nesse sentido, deve ser prática intencional do professor, planejado e estruturado, servindo como eixo estruturante para o desenvolvimento das demais atividades propostas.

Portanto, proporcionar uma aula pautada nas brincadeiras faz muito mais sentido para as crianças, pois, partimos de sua atividade principal. Sabemos que o ambiente escolar nem sempre é a princípio o local de preferência das crianças, pois elas ainda estão profundamente envolvidas 
com o círculo familiar de seu convívio. Tornar a aula divertida com intencionalidade ao propor o brincar na escola estreitando o vínculo entre aluno e professor, potencializa a aprendizagem e garante o desenvolvimento integral do aluno.

Dessa forma, a autora Adriana Friedmann considera que:

A atividade lúdica é decisiva no desenvolvimento das crianças porque as libera de situações difíceis. No brincar, as coisas e as ações não são o que aparentam ser; e, em situações imaginárias, as crianças começam a agir independentemente do que veem e a ser orientadas pelo significado da situação. A brincadeira das crianças préescolares, porém, permite-lhes descobrir que, como assevera Vygotsky, as ações têm sua origem muito mais em ideias do que em coisas. Quando isso acontece, a estrutura psicológica das crianças com a realidade altera-se radicalmente (FRIEDMANN, 2012, p.40).

O ato de brincar não é apenas uma dinâmica individual, mas sim, uma ação dotada de um grande significado social que necessita de aprendizagem e mediação. Como descreve o Manual de Orientação Pedagógica Módulo III (BRASIL, 2012, p. 8):

A brincadeira de alta qualidade faz a diferença na experiência presente e futura, contribuindo de forma única para a formação integral das crianças. As crianças brincam de forma espontânea, em 
qualquer lugar e com qualquer coisa, mas há uma diferença entre uma postura espontaneísta e outra reveladora de qualidade. A alta qualidade é resultado da intencionalidade do adulto que, ao complementar o eixo das interações e brincadeira, procura oferecer autonomia às crianças, para a exploração dos brinquedos e a recriação da cultura lúdica. É essa interação que resulta na intervenção que se faz no ambiente, na organização do espaço físico, na disposição de mobiliário, na seleção e organização dos brinquedos e materiais e nas interações com as crianças, a definição de interações educativas, o planejamento do ambiente educativo, o envolvimento das crianças, das famílias e das suas comunidades e, especialmente, a ação interativa 190 dos professores e da equipe escolar.

A seguir serão apresentadas propostas práticas planejadas intencionalmente relacionadas ao brincar:

\section{A Arte e a Amarelinha}

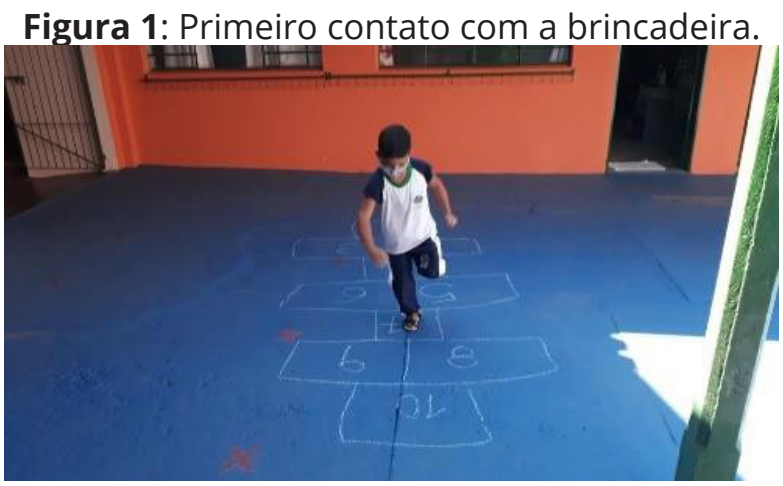

Fonte: Acervo pessoal (ano 2021) 
Intencionalidade: Desenvolver noções espaciais, auxiliando diretamente na organização do esquema corporal das crianças.

Descrição da proposta: Primeiramente foi apresentado para a criança a amarelinha para ser brincada livremente e, em seguida, com as regras. Após essa primeira vivência foi proposta a observação, leitura e releitura da obra A gangorra e a amarelinha (1937) do artista Cândido Portinari, onde as crianças puderam adquirir novos conhecimentos.

Figura 2: Produzindo a releitura da obra.
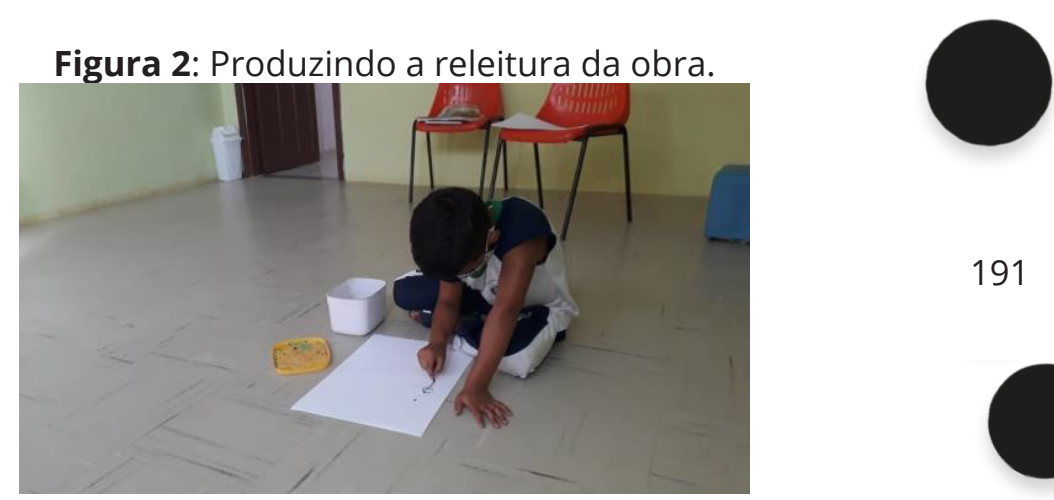

Fonte: Arquivo pessoal da pesquisadora (2021).

Descobertas: Durante a observação da obra, - aluno percebeu que uma pedra sustentava a gangorra, então, ele questionou o porquê daquela pedra. Para que ele pudesse descobrir o motivo lhe foi oferecido uma régua e algumas borrachas (material disponível naquele momento), rapidamente ele fez a grande descoberta: "A pedra serve de apoio e se eu colocar uma borracha de cada lado a régua fica certa". 
Figuras 3 e 4: A grande descoberta e a releitura

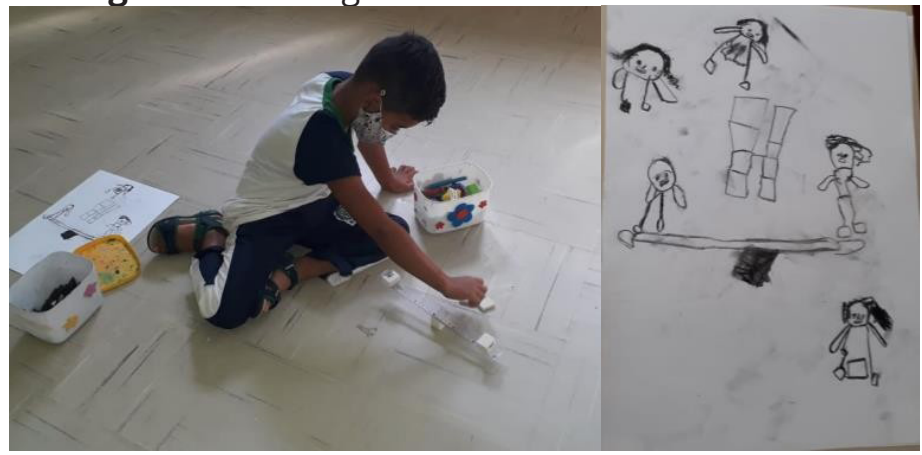

Fonte: Arquivo pessoal da pesquisadora (2021).

\section{Dança da Cadeira e Algumas Descobertas}

Intencionalidade: Propiciar vivências e explorações de atividades com ações corporais.

Figuras 5 e 6: Discutindo a quantidade de cadeiras e a

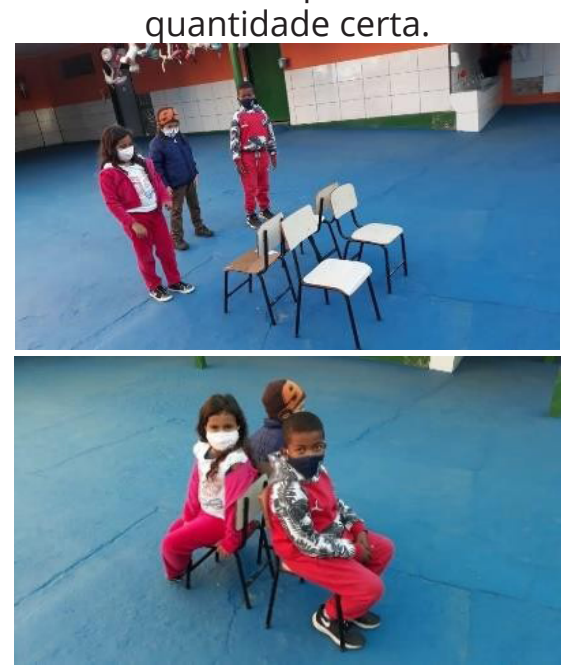

Fonte: Arquivo pessoal da pesquisadora (2021). 
Descrição da proposta: Inicialmente foram apresentadas as regras da brincadeira, aproveitando o momento para introduzir os conceitos de subtração e adição (somando e subtraindo as cadeiras). Um segundo momento, lançou-se o desafio de descobrir a quantidade total de cadeiras existentes na escola.

Montamos uma tabela na lousa, onde contávamos as cadeiras em seus respectivos ambientes, fazíamos as anotações na tabela, finalizando com a soma total. Encerrada a contagem, sugeriu-se fazer uma lista de participantes por meio de desenhos. Assim, com os desenhos prontos montamos a lista de participantes em um cartaz onde a professora foi escriba.

Figura 7: Tabela na lousa

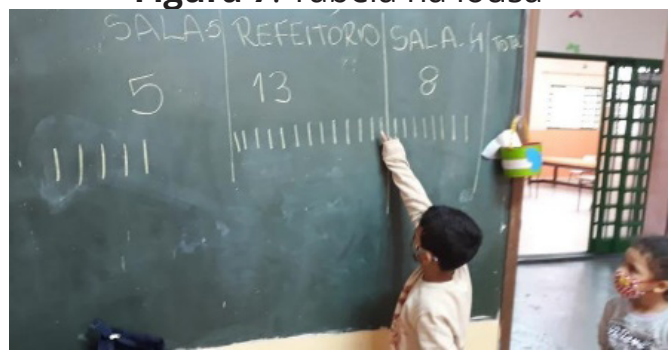

Fonte: Arquivo pessoal da pesquisadora (2021).

Para finalizar as crianças foram orientadas a apresentar a brincadeira para os familiares. Nessa direção, outro desafio foi sugerido: Quantas cadeiras cada aluno precisaria ter em casa para brincar?

Em uma roda de conversa pudemos descobrir especificidades próprias das famílias (quantidade de membros e suas características). Cada aluno 
representou sua família com massinha de modelar caseira, ampliando a aprendizagem e trabalhando o conceito de família.

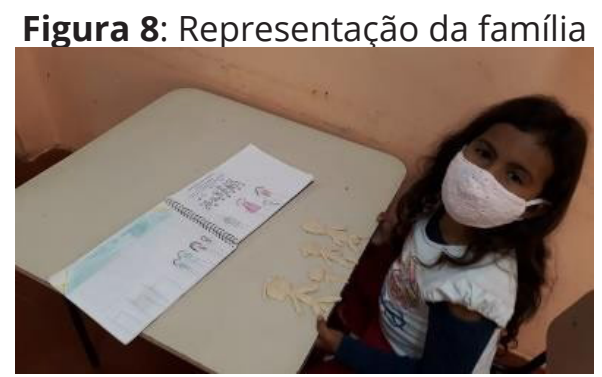

Fonte: Arquivo pessoal da pesquisadora (2021).

Descobertas: As crianças ficaram tão empolgadas com a descoberta da quantidade de cadeiras que haviam na escola que decidiram descobrir a quantidade de mesas também, e assim, partimos para outro desafio: descobrir a quantidade de mesas.

Em um outro momento de exploração livre da massinha observou-se que o aluno estava fazendo bolinhas e contando (trazendo para brincadeira livre o que havia aprendido na aula).

Figura 9: Exploração livre com massinha

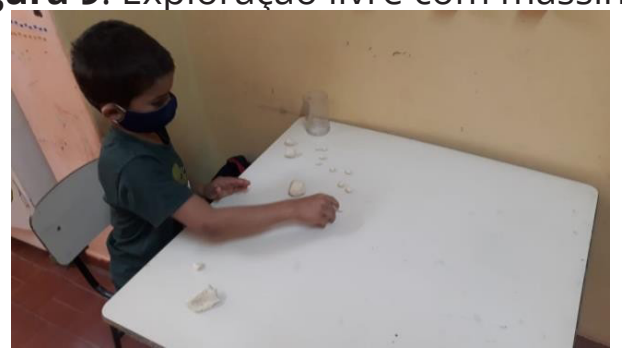

Fonte: Arquivo pessoal da pesquisadora (2021). 


\section{A Bola e o SOL}

Intencionalidade: Compreender o mundo e sua estrutura.

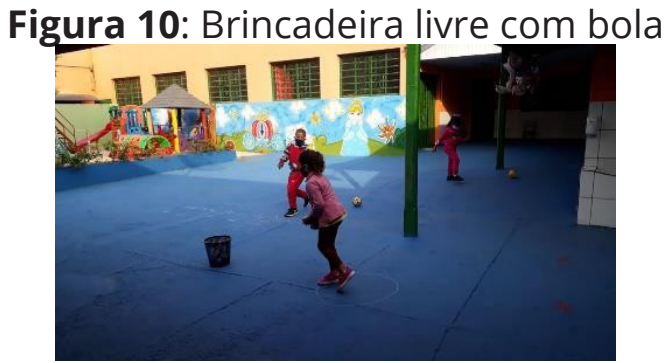

Fonte: Arquivo pessoal da pesquisadora (2021).

Descrição da proposta: A bola é um apoio pedagógico muito importante e pode ser utilizado em diferentes momentos, além de ser um objeto prático e de fácil acesso. Iniciamos a aula falando sobre a bola, em seguida, passamos para brincadeira livre, possibilitando a exploração espontânea do brinquedo. Logo após, propusemos uma atividade dirigida de bola ao cesto, o que oportunizou a contagem e análise da tabela, finalizamos com a leitura de imagem da obra Futebol (1935) de Cândido Portinari.

Figuras 11 e 12: Contando os jogadores e bola ao cesto

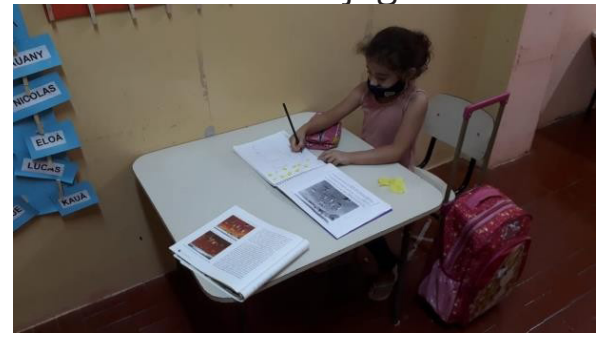




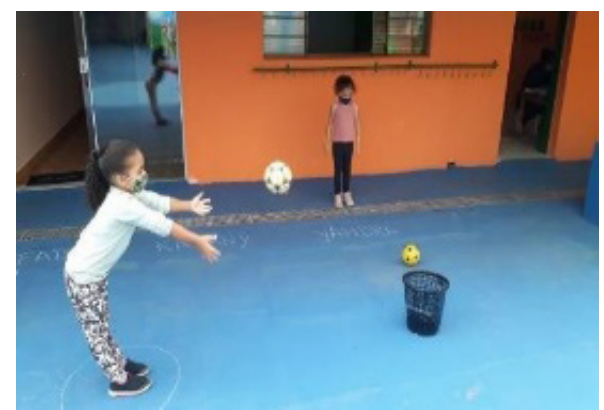

Fonte: Arquivo pessoal da pesquisadora (2021).

Descobertas:Além do prazer de brincar e registrar os pontos, essa atividade despertou o interesse nas crianças em formas redondas chegando até o sol, onde pudemos fazer várias descobertas científicas (por meio de observações e rodas de conversas) e 196 nos aprofundamos no assunto.

\section{A Obra e a Cambalhota}

Intencionalidade:

Desenvolvimento

da consciência estética.

Descrição da proposta: Iniciamos a aula com uma pergunta: Quem sabe o que é uma cambalhota? Após várias hipóteses, foi feita a leitura do texto A velhota cambalhota (1986) de Sylvia Orthof, onde tivemos a possibilidade de descobrir algumas rimas. Depois de discutirmos um pouco sobre o assunto,apresentou-se a obra Meninos brincando (1955) de Cândido Portinari, proporcionando uma roda de conversa. 
Figuras 13 e 14: Movimento da obra sob os olhares das crianças

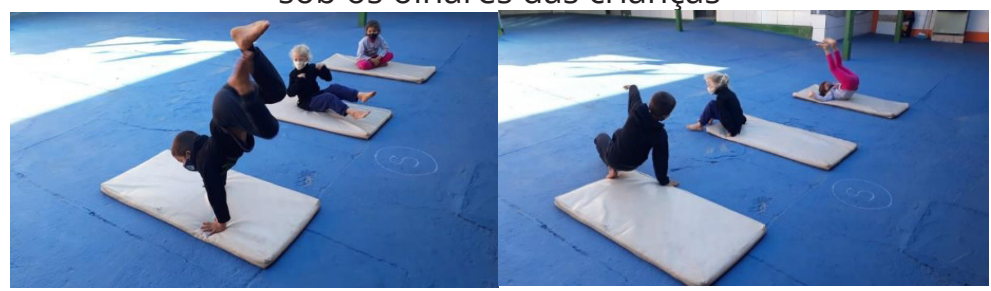

Fonte: Arquivo pessoal da pesquisadora (2021).

Roda de conversa:

-O que eles estão fazendo?

"Estão dando mortal!"

-E como seria isso? É fácil de fazer?

"Sim, é igual virar cambalhota, assim!"

Descobertas: Ao término da aula, as crianças estavam brincado livremente com alguns brinquedos, quando pude observar um dos alunos ensinando o "brinquedo" a dar cambalhotas, dizendo ser muito fácil, trazendo o que havia aprendido para o momento livre.

\section{Estilingue, História em Quadrinhos, \\ a Preservação e o Gráfico.}

Intencionalidade: Incentivar brincadeiras com brinquedos tradicionais permitindo a transmissão da cultura e estimulando a aprendizagem por meio de descobertas.

Descrição da proposta: iniciamos a aula com uma roda de conversa. 
Roda de conversa:

-Quem já viu um estilingue? Para que serve?

As crianças ficaram eufóricas, algumas não sabiam do que se tratava.

"Machuca"?

"É para jogar pedras".

Explico que o estilingue era usado antigamente como arma ou para caça.

-Será que podemos usá-lo de outra maneira?

"Podemos lançar as coisas".

E assim começaram nossas descobertas, as crianças brincaram de lançar bolinhas de papéis 198 em uma bacia. Num segundo momento, as crianças observaram e realizaram a leitura de imagens da história em quadrinhos do Papa-Capim: O estilingue de Mauricio de Sousa, possibilitando trabalharmos interpretação de texto.

Figuras 15 e 16: lançamento de bolinhas e leitura de imagens.

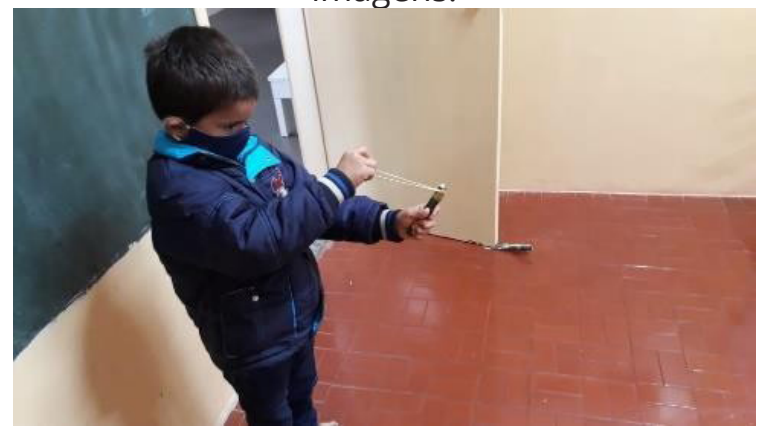




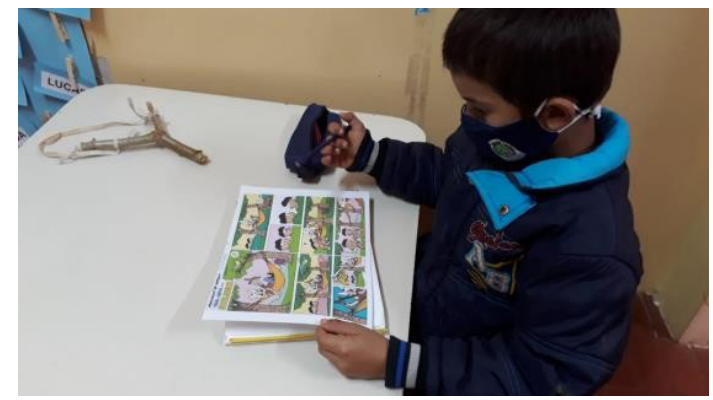

Fonte: Arquivo pessoal da pesquisadora (2021).

A história tem uma conotação ecológica, os personagens ficaram bravos pelo fato do homem estar tentando acertar os animais utilizando um estilingue. As crianças entenderam que era uma atitude errada, sendo assim, tivemos a oportunidade de trabalhar a preservação dos animais.

Inspirados pela história em quadrinhos resolvemos criar um estilingue gigante e lançar objetos.

Figura 17 e 18: Estilingue gigante

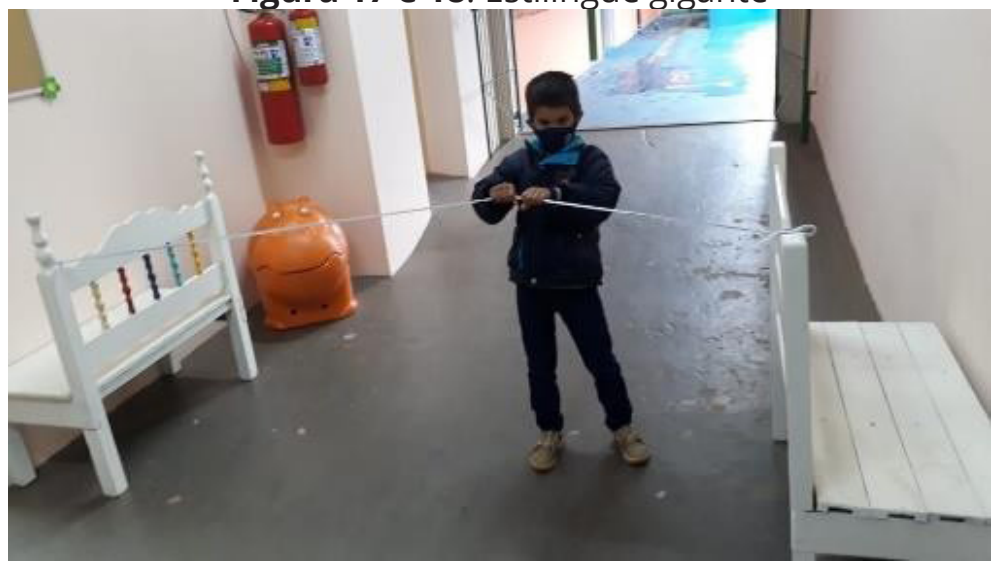




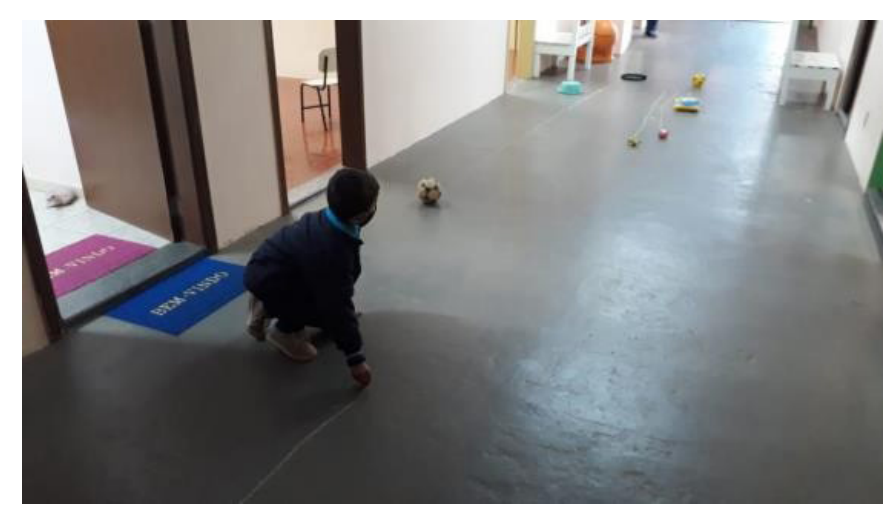

Fonte: Arquivo pessoal da pesquisadora (2021).

Descobertas: O tema nos possibilitou uma grata ampliação de repertório. Por se tratar de um grupo em que a maioria mora na zona rural pudemos 200 apreciar relatos de experiências vivenciadas com diversos espécies de animais (domésticos e selvagens), relatos que narravam diversas aventuras na fazenda e sua deversidade de espécies.

\section{Considerações Finais}

Brincar, brincar e brincar. É muito prazeroso para o professor quando o seu aluno chega para um novo dia de aula cheio de entusiasmo e ávido por novos saberes. Nesse sentido, foi isso que essas práticas de ensino baseadas nas brincadeiras planejadas e com intencionalidade puderam proporcionar as crianças.

O presente trabalho mostrou que ao oportunizar um ambiente lúdico, tendo como eixos estruturantes do trabalho docente intencional, as brincadeiras e interações, houve 
a promoção do desenvolvimento integral, bem como, foram respeitadas as especificidades da criança pequena no período da infância. Verificouse ainda, o importante papel do professor ao pesquisar práticas inovadoras e organizar 0 trabalho pedagógico, de forma, que se efetivasse a promocação e ampliação da aprendizagem e desenvolvimento de todos os alunos.

Semelhantemente, o presente estudo apresentou mediante as propostas de atividades que o brincar na escola de educação infantil, mediado pelo trabalho intencional do professor, vai muito além da transmissão de conhecimento. Foi possível resgatar uma infância que pode e deve ser vivida em sua totalidade. A criança se apropria dos elementos da cultura e da história quando brinca, levanta hipóteses e através da curiosidade atua nas tomadas de decisões, se tornando adulto capaz de resolver conflitos e transforfmar a sociedade em que vive.

Com relação aos resultados pôde-se acompanhar as deliciosas descobertas e grandes avanços de aprendizagens das crianças por meio de fotos e registros. Por fim, espera-se que esta pesquisa possa ampliar a percepção e prática de professores, educadores, pais e sociedade quanto a importância do brincar com qualidade na escola de educação infantil.

\section{REFERÊNCIAS}

BRASIL. Base Nacional Comum Curricular (BNCC). Segunda versão revista. Brasília, MEC/ 
CONSED/UNDIME, 2017. Disponível em: < http:// portal.mec.gov.br/index.php?option =com docman\&view=download\&alias=79601-anexo-textobncc-reexportado-pdf-2\&category_slug=dezembro2017-pdf\&ltemid=30192>. Acesso em: 07 mai. 2020.

BRASIL, Manual de Orientação Pedagógico, 2012, Módulo III.

FRIEDMANN, A. O brincar na Educação Infantil: Observação, adequação e inclusão. São Paulo: Moderna, 2012.

KISHIMOTO, T. M. Brinquedos e brincadeiras na educação infantil. In: I Seminário Nacional: Currículo em movimento, perspectivas Atuais, 1., 2010, Belo Horizonte. Anais do I Seminário Nacional: currículo em movimento. Perspectivas atuais. Belo Horizonte: Universidade Federal de Minas Gerais, 2010. v. 1. p. 1-20. Disponível em: http://portal.mec.gov.br/docman/ 202 dezembro-2010-pdf/7155-2-3-brinquedosbrincadeirastizuko-morchida/file. Acesso em: 27. Jul. 2021.

MOYLES, JR. A excelência do brincar. Porto Alegre: Artmed, 2006.

MOYLES, J.R. Só brincar? O papel do Brincar na educação infantil. Porto Alegre: Artmed, 2002.

THIOLLENT, M. Metodologia da pesquisa-ação. São Paulo: Cortez,1985. 


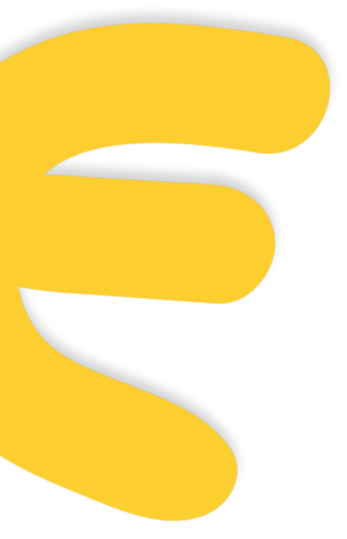





\title{
LUGARES DA INFÂNCIA: \\ OS AMBIENTES DE APRENDIZAGEM DA CRIANÇA \\ PEQUENA EM TEMPOS DE PANDEMIA COVID-19
}

Sintia Otuka Rossi

Alice Nicassio de Oliveira

Lígia Maria Ramazzini Remaeh

Vanessa Marinho Cunha Pescarollo

\begin{abstract}
INTRODUÇÃO
A covid -19 impôs uma ruptura no ano letivo de 2020, alterando o panorama da educação no Brasil e no mundo. $O$ ano iniciou como os outros na escola de educação infantil; primeiros dias de aula, acolhida das crianças e famílias, planejamento, reunião de pais e professores, bem como as demais ações que envolvem a organização de uma escola. Era mês de março, de repente, a inusitada situação de pandemia aconteceu e determinou um distanciamento social para a preservação da vida. Esse momento trouxe um novo desafio para o trabalho educativo da criança pequena: o ensino remoto.

O Parecer 05/2020 (BRASIL, 2020) estabeleceu no território nacional a reorganização do ano letivo e recomendou as atividades não presenciais em todas as etapas da educação. Conforme aponta o documento, "quanto mais novas são as crianças, mais importante é o trabalho de intervenção educativa e interação social para o seu desenvolvimento [...]" (BRASIL, 2020, p.9). Assim,
\end{abstract}


pensar sobre a intencionalidade, o sentido, as interações, o vínculo, a família, tempos e espaços de aprendizagem da criança na educação infantil, permearam as inquietudes a respeito de propostas de atividades planejadas, a serem realizadas com a mediação da família em um ambiente não formal de ensino. A escola nesse momento estava impossibilitada de ser um lócus privilegiado para as experiências e interações na infância. O espaço de aprendizagem era outro: o ambiente doméstico.

Nessa direção, o presente trabalho tem como objetivo apresentar as possibilidades de atividades intencionais em espaços não formais e recursos utilizados como promotores de aprendizagem e desenvolvimento em tempo de pandemia da 206 covid-19, em interlocução com os campos de experiência da Base Nacional Comum Curricular BNCC (BRASIL, 2017). A pesquisa está fundamentada como qualitativa (CHIZOTTI, 2010) e participativa respaldada em Severino (2007). Tem como aporte teórico a Base Nacional Comum Curricular (BRASIL, 2017), as Diretrizes Curriculares Nacionais para a Educação Infantil (BRASIL, 2010) e Oliveira (1993). A escrita sobre os ambientes e espaços de aprendizagem na educação infantil está embasada em Horn (2004) e Barbosa e Horn (2001) dentre outros autores. Os sujeitos envolvidos na pesquisa são 130 crianças, famílias, professores e equipe escolar de uma escola de educação infantil, localizada no Distrito de Tibiriçá, Município de Bauru/SP. 


\section{Reflexões sobre a Criança, o Outro e os Ambientes de Aprendizagem}

A infância é um período singular para a criança pequena, é nesse intervalo da vida que se estabelecem vínculos em interação com seus pares e nas vivências a ela oportunizadas. As Diretrizes Curriculares Nacionais para a Educação Infantil- DCNEI (BRASIL, 2010) citam que é por meio das brincadeiras, da imaginação, da fantasia, das narrativas, da observação e experiências que a criança, enquanto um ser histórico e social, questiona, elabora hipóteses, constrói sentido sobre o mundo, e produz cultura. Nessa direção, Kuhlmann Junior (2007, p. 30) descreve que:

É preciso considerar a infância como uma condição da criança. O conjunto de experiências vividas por elas em diferentes lugares históricos, geográficos e sociais é muito mais do que uma representação feita por adultos sobre esta fase da vida. É preciso conhecer as representações da infância e considerar as crianças concretas, localizálas nas relações sociais, etc., reconhecê-las como produtoras de história.

Logo, considerar a criança enquanto um sujeito histórico e social é concebê-la em relação com as pessoas, o meio em que está inserida, objetos da cultura e que mediante as suas experiências em diversas situações e contextos produz a história, 
elaborando conceitos sobre si, a partir do momento sócio histórico em que decorre.

$\mathrm{Na}$ concepção de Vygotsky (OLIVEIRA, 1993) a criança aprende em interação com seus pares, crianças e adultos, com os objetos e o mundo a sua volta; e do mesmo modo, se apropria dos conhecimentos materiais e imateriais historicamente acumulados. Nessa direção, destaca-se a importância da escola enquanto espaço de educação, rico e privilegiado, que oportuniza o contato das crianças pequenas com o patrimônio cultural. O professor é a figura mais experiente e com a responsabilidade do trabalho educativo intencional. A sua prática tem como pressupostos o conhecimento sobre o conteúdo, 208 a compreensão das especificidades da faixa etária a quem se destina e a forma mais adequada no desenvolvimento do ensino.

Outrossim, o ambiente de uma escola infantil além de se constituir em um local seguro e acolhedor, deve ainda, promover as relações, convivências e interações que influenciam na aprendizagem e na qualidade de vida daqueles que dele usufruem.

Sobre a conceituação de meio Galvão (1995) apud Horn (2004, p.15) descreve que:

Os textos disponíveis atualmente sobre a organização espacial nas escolas, em especial nas salas de aula, referem-se, na maior parte dos casos, à íntima relação 
entre as interações sociais das crianças e suas aprendizagens, intermediadas pelo meio onde estão inseridas, cenário desse processo. Meio é aqui entendido como o campo onde a criança aplica as condutas de que dispõe. Ao mesmo tempo, é dele que retira os recursos para sua ação.

Nessa direção, delinear-se-ão as definições para os termos ambiente e espaço, de forma que Forneiro (1998, p.232-233) aponta:

O termo espaço refere-se ao espaço físico, ou seja, aos locais para a atividade caracterizados pelos objetos, pelos materiais didáticos, pelo mobiliário e pela decoração.

Já o termo ambiente refere-se ao conjunto do espaço físico e às relações que se estabelecem no mesmo (afetos, as relações interpessoais entre as crianças, entre crianças e adultos, entre crianças e sociedade em seu conjunto).

\section{Horn (2004, p.20) parafraseando Vygotsky descreve que:}

No caso da criança em idade préescolar, o papel do adulto é o de parceiro mais experiente que promove, organiza e provê situações em que as interações entre crianças e o meio sejam provedoras de desenvolvimento. Nessa dimensão, o espaço se constitui no cenário onde esse processo acontece, mas nunca é neutro. 
O arranjo do espaço escolar reflete a concepção de criança, de ensino, de educação e os objetivos que se quer alcançar, logo, Freire (1986) pontua que o espaço é a imagem retratada da relação pedagógica. Assim, desde pequena a criança reconhece o espaço físico e lhe atribui significados.

\section{O Ambiente de Aprendizagem, as \\ INTERAÇÕES E OS CAMPOS DE EXPERIÊNCIA}

Segundo Oliveira (1993, p.24) Vygotsky aponta que "a relação do homem com o mundo não é uma relação direta, mas uma relação mediada, sendo os sistemas simbólicos os elementos intermediários entre o sujeito e o mundo". Dessa maneira, a aprendizagem da criança de zero a cinco anos 210 ocorre mediada pelos signos e pela cultura.

Nesse período da infância as vivências e experiências oportunizadas às crianças são determinantes para uma maior ou menor ampliação da aprendizagem. A BNCC (BRASIL, 2017) descreve as interações e brincadeiras como eixos estruturantes para o trabalho pedagógico, a fim de assegurar os direitos de conviver, brincar, participar, explorar, expressar e conhecer-se, estruturados em cinco campos de experiência. Sob esse ponto de vista, seguem os campos de experiência, as orientações em relação aos saberes e conhecimentos fundamentais em cada um deles e a importância do trabalho educativo na educação infantil: 


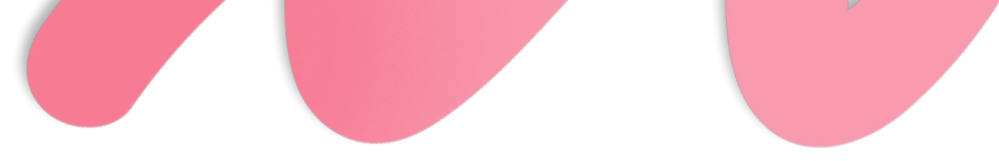

O eu, o outro e o nós - É na interação com os pares e com adultos que as crianças vão constituindo um modo próprio de agir, sentir e pensar e vão descobrindo que existem outros modos de vida, pessoas diferentes, com outros pontos de vista. [...] é preciso criar oportunidades para que as crianças entrem em contato com outros grupos sociais e culturais, outros modos de vida, diferentes atitudes, técnicas e rituais de cuidados pessoais e do grupo, costumes, celebrações e narrativas. [...]

Corpo, gesto e movimentos - Com o corpo [...] as crianças, desde cedo, exploram o mundo, o espaço e os objetos do seu entorno, estabelecem relações, expressam-se, brincam e produzem conhecimentos sobre si, sob re o outro, sobre o universo social e cultural, tornando-se progressivamente, conscientes dessa corporeidade. Por meio das diferentes linguagens como a música, a dança, o teatro, as brincadeiras de faz de conta, elas se comunicam e se expressam no entrelaçamento entre corpo, emoção e linguagem. [...] a instituição escolar precisa promover oportunidades ricas para que as crianças possam, sempre animadas pelo espírito lúdico e na interação com seus pares, explorar e vivenciar um amplo repertório de movimentos, gestos, olhares, sons e mímicas com o corpo para descobrir variados mo0dos de ocupação e uso do espaço com o corpo [...].

Traços, sons, cores e formas - Conviver com diferentes manifestações artísticas, culturais e cientificas, locais e universais, no cotidiano da instituição escolar, possibilita às crianças, por meio de experiências diversificadas, vivenciar diversas formas de expressão e linguagens, como 
as artes visuais (pintura, modelagem, colagem, fotografia, etc.), a música, o teatro, a dança e o audiovisual, entre outras. [...] precisa promover a participação das crianças em tempos e espaços para a produção, manifestação e apreciação artística a, de modo a favorecer o desenvolvimento da sensibilidade, da criatividade e da expressão pessoal das crianças, permitindo que se apropriem e reconfigurem, permanentemente, a cultura e potencializem suas singularidades, ao ampliar repertórios e interpretar suas experiências e vivências artísticas.

Escuta, fala, pensamento e imaginação - Desde o nascimento, as crianças participam de situações comunicativas cotidianas com as pessoas com as quais interagem. [...] é importante promover experiências nas quais as crianças possam falar e ouvir, potencializando sua participação na cultura oral, nas descrições, nas narrativas[...].

Desde cedo, a criança manifesta curiosidade com relação à cultura escrita ao ouvir e acompanhar a leitura de textos, ao observar os muitos textos que circulam no contexto familiar, comunitário e escolar, ela vai construindo sua concepção de língua escrita, reconhecendo diferentes usos sociais da escrita, dos gêneros, dos suportes e portadores. [...] o contato com histórias, contos, fábulas, poemas, cordéis etc. propicia familiaridade com livros, com diferentes gêneros literários, a diferenciação entre ilustrações e escrita, a aprendizagem da direção da escrita e das formas corretas de manipulação de livros [...] as crianças vão construindo hipóteses sobre a escrita que se revelam, inicialmente, em rabiscos e garatujas 
e, a medida que vão conhecendo letras, em escritas espontâneas, não convencionais, mas já indicativas da compreensão da escrita como sistema de representação da língua.

Espaços, tempos, quantidades, relações e transformações - As crianças vivem inseridas em espaços e tempos de diferentes dimensões, em um mundo constituído de fenômenos naturais e socioculturais. Desde muito pequenas, elas procuram se situar em diversos espaços (rua, bairro, cidade, etc.) e tempos (dia e noite; hoje, ontem e amanhã etc.). Demonstram curiosidade sobre o mundo físico (seu próprio corpo, os fenômenos atmosféricos, os animais, as plantas, as transformações da natureza, os diferentes tipos de materiais e as possibilidades de sua manipulação etc.) [...] as crianças também se deparam, frequentemente, com conhecimentos matemáticos (contagem, ordenação, relações entre quantidades, dimensões, medidas, comparação de pesos e de comprimentos, avaliação de distâncias, reconhecimento deformas geométricas, conhecimento e reconhecimento de numerais cardinais e ordinais etc.) que igualmente aguçam a curiosidade. Portanto, a Educação precisa promover experiências nas quais as crianças possam fazer observações, manipular objetos, investigar e explorar seu entorno, levantar hipóteses e consultar fontes de informação para buscar respostas às suas curiosidades e indagações. [...].

Com efeito, o professor salvo a diversidade e especificidade existente em cada escola, ao planejar intencionalmente sua prática pedagógica, até 
recentemente, contava com um espaço educador coletivo provido de recursos pedagógicos como os jogos, livros, brinquedos e materiais relacionados ao cotidiano de ensino na educação infantil. O contexto peculiar marcado pela covid-19 e a necessidade do distanciamento social trouxeram novas ressignificações aos aspectos inerentes à educação, tais como: currículo, papel do professor, espaço de aprendizagem, materiais e recursos pedagógicos, tecnologia e outras situações, que necessariamente tiveram que ser pensadas e replanejadas para atender a mais recente forma de acesso ao ensino, agora à distância, na educação infantil.

Ao pensar no ambiente escolar como o lugar em que as crianças da educação infantil se inserem 214 e estabelecem relações e interações, é que se propõe a refletir sobre a organização do trabalho pedagógico que privilegie as vivências e experiências de aprendizagens, por meio do ensino remoto.

Com a ausência do espaço físico coletivo da escola, planejado e organizado para a promoção de conhecimento, cabe aqui, avaliar sobre qual é o ambiente em que o ensino e aprendizagem da criança na faixa de zero a cinco anos está ocorrendo. Há de se considerar a diversidade cultural, econômica e social em que cada criança está imersa e a realidade plural de cada família. O espaço real das interações e experiências agora é o ambiente familiar. 


\section{A Organização do Trabalho Pedagógico no Âmbito do Ambiente NÃo Escolar: UMA EXPERIÊNCIA NA EdUCAÇÃo INFANTIL}

A organização do trabalho pedagógico para as crianças da educação infantil é permeada por atividades planejadas intencionalmente por professores e tem como recursos pedagógicos o ambiente e equipamentos materiais em relação à estruturação do tempo na escola. À vista disso, é atribuição do professor articular o espaço e o tempo das creches e pré-escolas objetivando as máximas aprendizagens e desenvolvimento das crianças.

Sobre essa organização do espaço e tempo escolar Barbosa e Horn (2001, p. 67) salientam que:

Organizar o cotidiano das crianças da Educação Infantil pressupões pensar que o estabelecimento de uma sequência básica de atividades diárias é, antes de mais nada, o resultado da leitura que fazemos do nosso grupo de crianças, a partir, principalmente, de suas necessidades. É importante que o educador observe o que as crianças brincam, como essas brincadeiras se desenvolvem, o que mais gostam de fazer, em que espaços preferemficar, o quelhes chama a atenção, em que momentos do dia estão mais tranquilos ou mais agitados. Esse conhecimento é fundamental para que a estruturação espaço-temporal tenha significado. Ao lado disto, também é importante considerar o contexto sociocultural no qual se insere e 
a proposta pedagógica da instituição, que deverão lhe dar suporte.

Sobre a influência da organização dos ambientes Horn (2004, p.61) acrescenta:

As escolas de educação infantil têm na organização dos ambientes uma parte importante de sua proposta pedagógica. Ela traduz as concepções de criança, de educação, de ensino e aprendizagem, bem como uma visão de mundo e de ser humano do educador que atua nesse cenário. Portanto, qualquer professor tem, na realidade, uma concepção pedagógica explicitada no modo como planeja suas aulas [...]

216

O momento pandêmico não permite o desenvolvimento do trabalho educativo presencial, portanto, está ausente o ambiente escolar que também é educador. A vista disso, apresentar-se-á um relato de experiência sobre as possibilidades no planejamento e propostas de atividades não presenciais, bem como alguns registros de sua realização em ambiente doméstico. Cabe ainda, atentar para as possibilidades alcançadas nas vivências e experiências das crianças nesse meio. Foi possível interações com seus pares? O espaço de casa proporcionou aprendizagens, descobertas, brincadeiras em diálogo com os campos de experiência? 
O relato foi desenvolvido na Escola de Educação Infantil Angélica Leite de Freitas, Distrito de Tibiriçá, Município de Bauru/SP e ocorreu de abril a dezembro de 2020. Foram sujeitos da pesquisa 130 crianças matriculadas, com faixa etária de zero a cinco anos, famílias, professores e equipe escolar. Trata-se de uma escola de período integral, única no distrito com atendimento em creche e préescola, sendo ela, uma organização da sociedade civil, sem fins lucrativos. A metodologia está fundamentada em pesquisa qualitativa que como cita Chizzotti (2010) se refere à "partilha intensa com pessoas, situações e lugares que constituem objetos de pesquisa, para extrair dessa vivência os significados relevantes que se tornam perceptivos por meio de uma atenção sensível"., e participativa descrita em Severino (2007, p.120):

Éaquela emqueopesquisador, pararealizar a observação dos fenômenos, compartilha a vivência dos sujeitos pesquisados, participando, de forma sistemática e permanente, ao longo do tempo da pesquisa, das suas atividades [...] observando as manifestações dos sujeitos e as situações vividas, vai registrando descritivamente todos os elementos observados bem como as análises e considerações que fizer ao longo dessa participação.

A chegada da Covid 19 trouxe um novo cenário para as práticas dos professores. Foi preciso 
pensar novas formas para o processo de ensino e aprendizagem e para tanto, foi necessário fazer um diagnóstico da realidade de cada criança e família. Algumas inquietações surgiram, como: onde moram estas famílias? Com quem estão essas crianças? Quem fará a mediação do ensino? A tecnologia e internet estão ao alcance delas? Qual seria o recurso mais acessível a todos? Sobre o currículo, entre o necessário e o possível, quais experiências de aprendizagem oportunizar? Em que ambiente se desenvolveriam essas vivências? Quais materiais poderiam ser usados?

Diante de tantas indagações, as reuniões virtuais realizadas entre a coordenação pedagógica e a equipe de professores foram essenciais para o 218 diálogo e o replanejamento de novas metodologias para o processo de ensino. Como cerca de $30 \%$ das famílias moravam em sítios e fazendas nos arredores do distrito, as redes sociais e grupos de mensagem acessadas por meio do celular em sua grande maioria - foram as mídias escolhidas para a comunicação com as famílias, a fim de orientar, como também, enviar as sugestões de atividades. Ao considerar que as crianças estavam restritamente com suas famílias, a concretude de atividades e demais ações somente seriam exequíveis em estreita parceria com elas, sendo estas, as mediadoras do ensino e aprendizagem das crianças.

Vale ponderar, que o contexto concreto para o desenvolvimento de situações de aprendizagem 
eram as suas residências, quintais, sítios e fazendas. Assim, ao planejar suas atividades tinham não mais o espaço escolar, e sim, o ambiente doméstico em suas particularidades, recursos como elementos da natureza e materiais não estruturados, além disso, as relações interpessoais entre crianças, escola e família.

Replanejar, adaptar e reavaliar foi necessário!

As VivênCias de Aprendizagem em Interlocução com os

Campos de Experiência: Algumas Possibilidades

As Diretrizes Curriculares Nacionais para a Educação Infantil- DCNEI (BRASIL, 2010, p. 35) normatizam em seu artigo $9^{\circ}$ que os eixos estruturantes da prática educativa são as inteirações e a brincadeira, experiências que propiciam às crianças a construção e apropriação de conhecimentos mediante suas ações e interações com seus pares - crianças e adultos - promovem aprendizagens, desenvolvimento e socialização.

Ao observar as interações e a brincadeira entre as crianças e delas com os adultos, é possível identificar, por exemplo, a expressão dos afetos, a mediação das frustrações, a resolução de conflitos e a regulação das emoções.

Nessa significação, as propostas de atividades pretenderam para além do trabalho educativo, oportunizar a ampliação de vínculos entre a família, 
a participação em sua realização, a fim de que estas, pudessem inclusive, mediar as frustrações, as inseguranças e emoções presentes nesse cenário de crise. Igualmente, assegurar por meio dos seus direitos de aprendizagem e desenvolvimento "situações nas quais possam desempenhar um papel ativo em ambientes que as convidem a vivenciar desafios e a sentirem-se provocadas a resolvê-los, nas quais possam construir significados [...] (BRASIL, 2017, p.35).

A seguir apresentar-se-á as possibilidades de atividades e os registros de sua realização durante o ensino remoto em espaços não escolares articulados aos campos de experiência.

o eu, o outro e o nós - as propostas nesse

220 campo foram pensadas e adaptadas à real situação de distanciamento e impossibilidade de interações entre outras crianças e adultos. Nesse sentido, priorizou-se situações de aprendizagem em que as crianças pudessem interagir com seus familiares, de forma que ampliassem o vínculo entre eles, partilhassem de momentos de interação familiar por meio da exploração dos espaços, objetos, materiais e brincadeiras. As ações sugeriam a percepção de si e do outro, bem como suas características; a expressão de sentimentos e sensações em momentos de higiene e cuidado; a demonstração de cuidado e respeito consigo, com as pessoas com as quais convive e com a natureza. 
Figuras 1,2,3 e 4: devolutivas das propostas
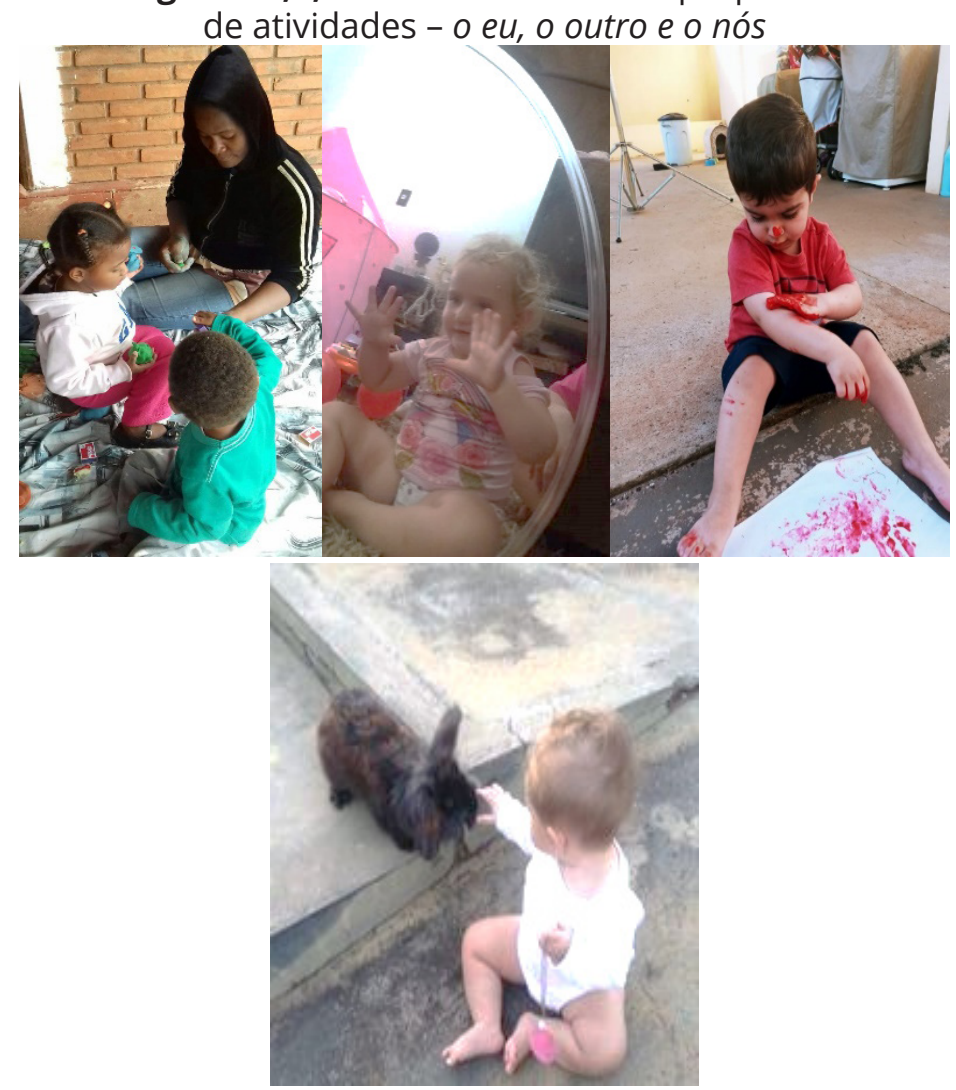

Fonte: Novos olhares e possibilidades para a infância (2020)

Corpo, gestos e movimentos - O planejamento das açõesnesse campo objetivou as experimentações e possibilidades corporais, bem como o manuseio de diferentes materiais, de forma a ampliar as habilidades e destrezas corporais por meio de brincadeiras e interações em ambiente doméstico. Também, favorecer contextos em que pudessem 
criar diferentes formas de expressão de sentimentos, emoções e sensações, tanto em situações do cotidiano como em brincadeiras e jogos, histórias, atividades artísticas e demais possibilidades.

Figuras 5,6,7 e 8: registros da realização de atividades propostas - corpo, gestos e movimento

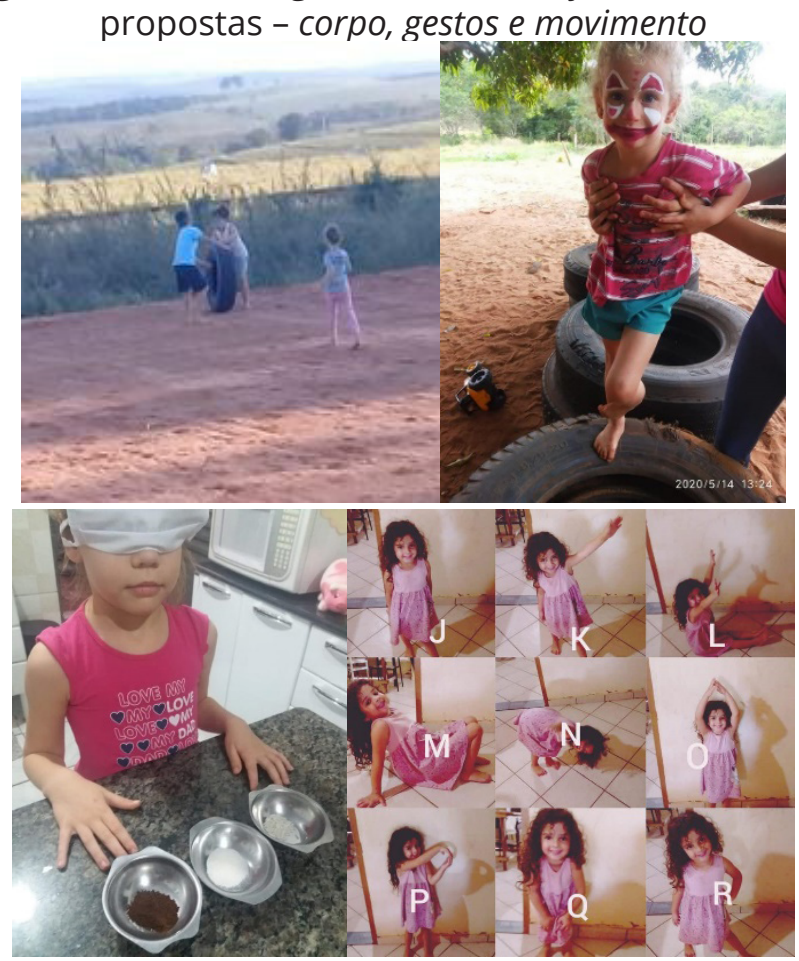

Fonte: Novos olhares e possibilidades para a infância (2020)

Traços, sons, cores e formas - nesse campo foram oportunizadas as explorações e experimentações de texturas, materiais não estruturados como elementos da natureza e sucatas, 

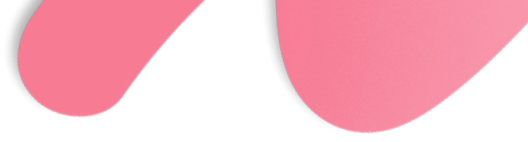

modelagens e criações bi e tridimensionais com melecas e massinhas. Ademais, as atividades tiveram o intuito de desenvolver e alargar o potencial criador infantil por meio do faz-de-conta, do desenho, da música, pinturas e demais possibilidades.

Figuras 9,10,11 e12: experiências de aprendizagem realizadas em casa - traços, sons, cores e formas

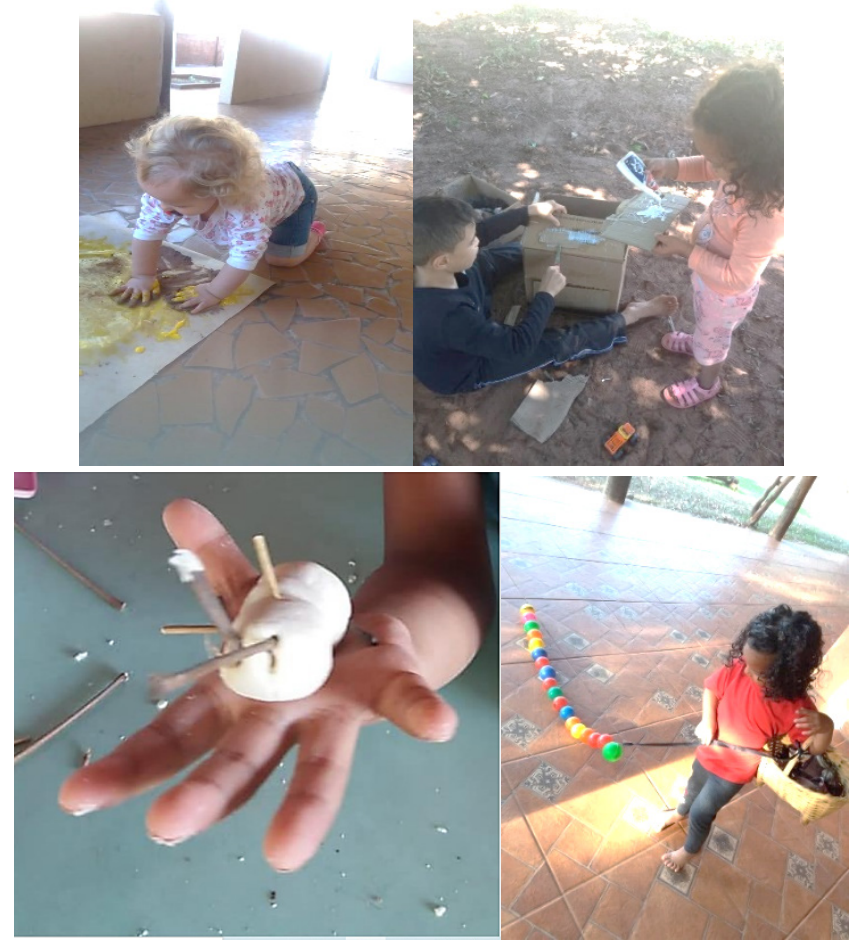

Fonte: Novos olhares e possibilidades para a infância (2020)

Escuta, fala, pensamento e imaginação - no respectivo campo priorizou-se a escuta e reconto 
de histórias, em situações em que as crianças pudessem comunicar-se com as pessoas do seu entorno, expressando suas ideias, sentimentos e desejos. Logo, participar de circunstâncias em que pudessem ter contato com diferentes gêneros textuais e manipular diferentes instrumentos e suportes de escrita a fim de levantar hipóteses em relação a linguagem e escrita.

Figuras 13,14,15 e 16: vivências e experiências de escuta, fala, pensamento e imaginação
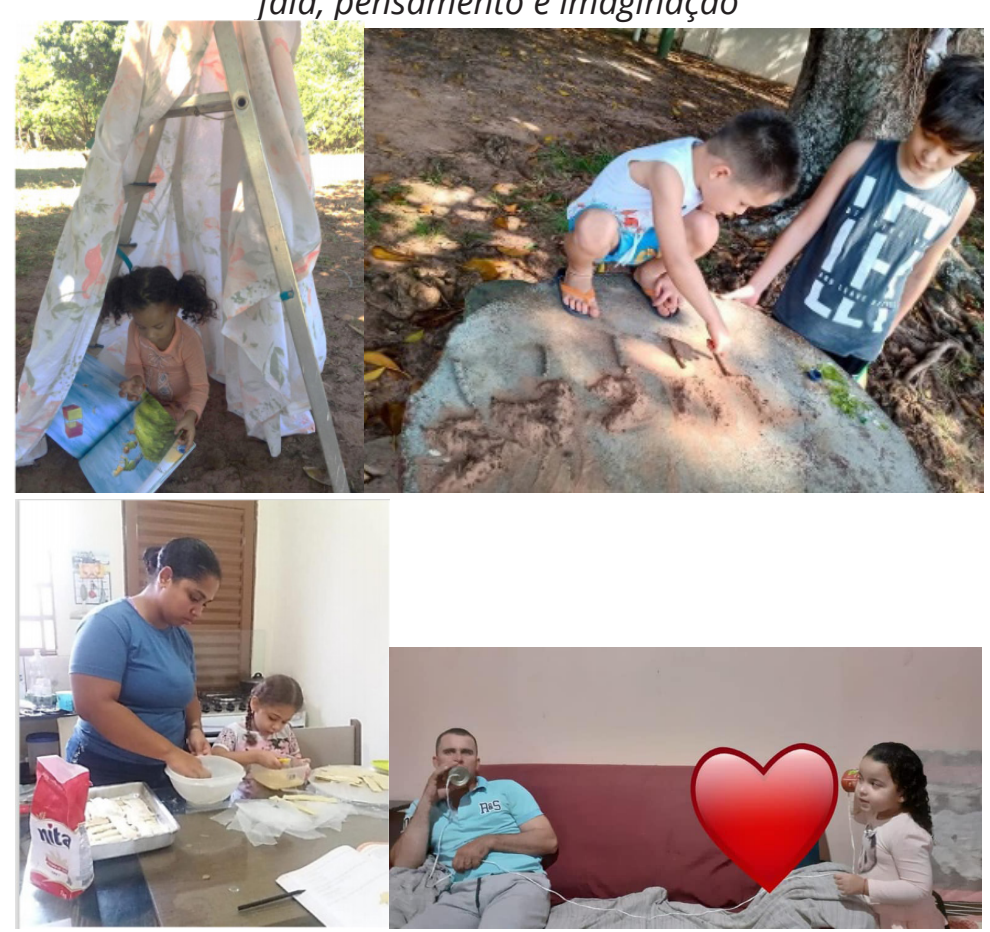

Fonte: Novos olhares e possibilidades para a infância (2020) 

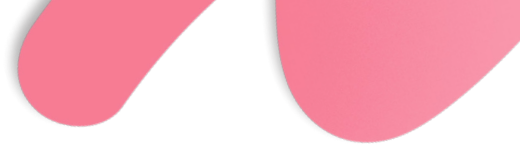

Espaços, tempos, quantidades, relações e transformações - as propostas de atividades nesse campo privilegiaram as descobertas e conhecimento sobre as características e formas dos objetos, observação dos fenômenos da natureza, comparações e identificação de informações, a fim de responder questões e hipóteses, bem como, situações que envolvessem a contagem e quantidades.

Figuras: 17,18,19 e 20: possibilidades de aprendizagem realizadas em casa sobre espaços, tempos, quantidades, relações e transformações
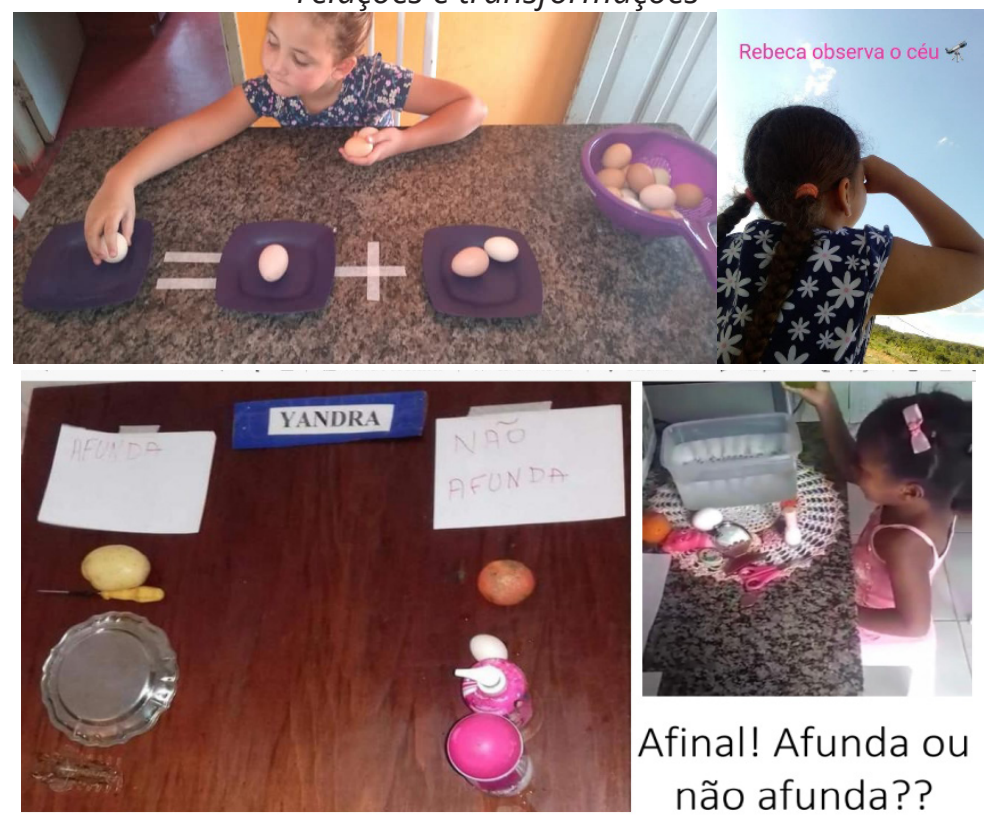

Fonte: Fonte: Novos olhares e possibilidades para a infância (2020, p.55) 
A seguir uma breve avaliação do trabalho desenvolvido em ambiente doméstico no olhar da criança e da família.

\author{
E as Crianças o que Acharam de Tudo Isso? \\ Ao finalizar o ano letivo, as crianças deixaram \\ registradas as suas impressões e sentimentos \\ quanto ao desenvolvimento das propostas de \\ ensino em casa, como segue:
}

Figura 21: percepções das crianças sobre as atividades durante o ensino remoto

\section{Olhares das criancas...}

"Eu gostei das brincadeiras e também de fazer as atividades em casa. A atividade que eu mais gostei foi de fazer o bolo. Senti falta da escola e dos meus amiguinhos."

"Eu amei fazer as atividades com a mamãe, a atividade que eu mais amei foi a da Pipaaaa. Senti falta dos meus amigos e das tias da creche."

"Sim, gostei de fazer as atividades, achei legal fazer as atividades com a minha família, todas as atividades foram legais. Senti falta da escola, da comida da tia Tera e da tia Marizete, das atividades e das brincadeiras."
"Eu gostei das brincadeiras e das atividades. A atividade que eu mais gostei foi a do flutua ou afunda. Senti falta da escola e de brincar com os meus amiguinhos."

Eu gostei e achei legal fazer as brincadeiras e atividades em casa com minha família. O mais divertido e eu mais gostei foram as atividades do Patinho Feio e o Rei Capitão Soldado Ladrão. Senti falta da escola, dos meus amiguinhos, das brincadeiras e das florzinha do parque."

"Eu gostei das brincadeiras propostas durante o ano. Achei legal fazer as atividades com minha família. Gostei mais de todas. Senti falta da escola, dos meus amiguinhos, da professora. Beijos e tchau amiguinhos."

Fonte: Novos olhares e possibilidades

para a infância (2020, p.135)

A Avaliação da Famílıa

As famílias foram essenciais para a efetivação do ensino remoto. Sem a parceria da família para a mediação das atividades propostas, esse trabalho 
não poderia ser realizado. Abaixo estão descritos olhares de algumas famílias sobre as vivências e experiências em tempos de pandemia.

Figura 22: avaliação das famílias sobre o ensino remoto

"Foi muito bom ...

Gostamos muito...

Gostamos muito...

Muito, muito criativo,
"Eu agradeço muito à Escola por todas as atividades que foram

enviadas. Foi muito produtivo, aprendemos todos juntos aqui em casa."

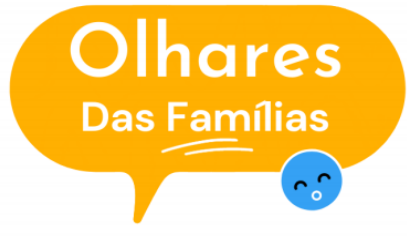

"Meu filho foi só uma semana de aula na creche. Não deu tempo dele aprender muito, pois a Escola fechou por causa da pandemia."
"Com a Pandemia surgiram principais delas dúvidas e as que fazer com nossas: $E$ agora, o não irão em casa ? Elas crianças prender nas

No decorrer este ano?

dos dias foi decorrer

um pouco destivel desanuviar

quando costa ansiedade.

chegar em nosseçaram a primeiros roteiros celulares os Seguindo de atividades. roteiros encaino esses professoras ados pelas proporcionado, nos foi momentos muitamente, enriquecedes muito construtivos que divertidos e contribuíram que com certeza intelectual, social o crescimento minha filha."

Fonte: Novos olhares e possibilidades

para a infância (2020, p.133)

\section{Considerações Finais}

A escola de educação infantil é o espaço privilegiado para as interações, brincadeiras, vivências e experiências da criança pequena. Os ambientes intencionalmente planejados e organizados são considerados como um educador e juntamente com os recursos e materiais colaboram para a promoção de aprendizagem e desenvolvimento infantil. Com a chegada da pandemia covid-19 esse cenário mudou, o trabalho educativo sofreu uma ruptura e o ensino passou a ser desenvolvido de forma remota. 
O presente artigo teve como objetivo apresentar as possibilidades de vivências e experiências de aprendizagem intencionalmente planejadas por professores, a serem desenvolvidas em espaços não formais mediados pela família em interlocução com os campos de experiência da BNCC (BRASIL, 2017). Esse momento solicitou novos olhares para a educação, diante dos desafios propostos pelo distanciamento social e a especificidade do trabalho educativo na educação infantil. Considerando que a criança pequena aprende e se desenvolve em integração com o outro - adultos, crianças e com o meio - e tem na escola da infância ambiente, espaço, equipamentos e materiais disponíveis ao trabalho educativo, nesse novo contexto, foi possível

228 verificar que o ambiente doméstico apresentou novas possibilidades para a aprendizagem e desenvolvimento da criança. O planejamento docente passou por adequações quanto ao currículo e as formas de ensino, visando atender essa criança que tem como pares a sua família, o seu entorno como espaço de aprendizagem, assim como elementos da natureza, sucatas e outros materiais não estruturados como recursos para o desenvolvimento das propostas de ensino.

Do mesmo modo, verificou-se que mesmo com as limitações ditadas pelo distanciamento social houve interação entre a crianças e os membros de sua família, objetos do seu cotidiano, ambiente e natureza, ampliadas mediante as 
U

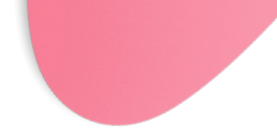

sugestões de atividades oportunizadas pela escola. Semelhantemente, constatou-se que as crianças vivenciaram os direitos de aprendizagem e desenvolvimento de conviver, brincar, participar, explorar, expressar e conhecer-se por meio das propostas de atividades planejadas por professores compreendendo os cinco campos de experiência em ambiente não formal de ensino.

Assim, espera-se que esse trabalho possa contribuir para novos olhares sobre o planejamento e organização do trabalhado pedagógico na educação infantil, quanto ao uso de ambientes, espaços, equipamentos e materiais para a promoção de uma educação de qualidade. Por fim, almeja-se ainda que essa pesquisa possa contribuir para a reflexão das famílias e sociedade quanto a importância do trabalho docente a favor do desenvolvimento integral da criança pequena.

\section{REFERÊNCIAS}

BARBOSA, M. C. S.; HORN, M. G. S. Organização do espaço e do tempo na escola infantil. In: CRAIDY, C.; KAERCHER, G. E. Educação Infantil. Pra que te quero? Porto Alegre: Artmed, 2001, p. 67-79.

BRASIL. Base Nacional Comum Curricular. Brasília: Ministério da Educação, 2017. Disponível em http:// basenacionalcomum.mec.gov.br/abase. Acesso em 22.06.2021

Diretrizes curriculares nacionais para a educação infantil. Brasília: MEC/SEB, 2010. 
. Parecer CNE/CP n. 5/2020, Brasília: MEC, 2020.

CHIZZOTTI, A. Pesquisa qualitativa em ciências humanas e sociais. 3. ed. Petropólis: Vozes, 2010.

FREIRE. M. A paixão de conhecer o mundo: relato de uma professora. Rio de Janeiro: Paz e Terra, 1983.

FORNEIRO, L.I. A organização dos espaços na Educação Infantil. In: ZABALZA, M.A. Qualidade em educação infantil. Porto Alegre: Artmed, 1998.p.229-281.

HORN, M.G.S. Sabores, cores, sons, aromas. A organização dos espaços na Educação Infantil. Porto Alegre: Artmed, 2004.

KUHLMANN, M. J. Infância e Educação Infantil: uma abordagem histórica. 6. ed. Porto Alegre: Mediação, 2011.

OLIVEIRA, M.K. Vygosky aprendizado e desenvolvimento. Um processo sócio-histórico. São Paulo: Scipione, 1993.

ROSSI, S.O. Novos olhares e possibilidades para a 230 infância [recurso eletrônico] /Sintia Otuka Rossi et al. Bauru, 2020. ISBN 978-65-00-15255-5

SEVERINO, A J. Metodologia do trabalho científico. São Paulo: Cortez, 2007. 


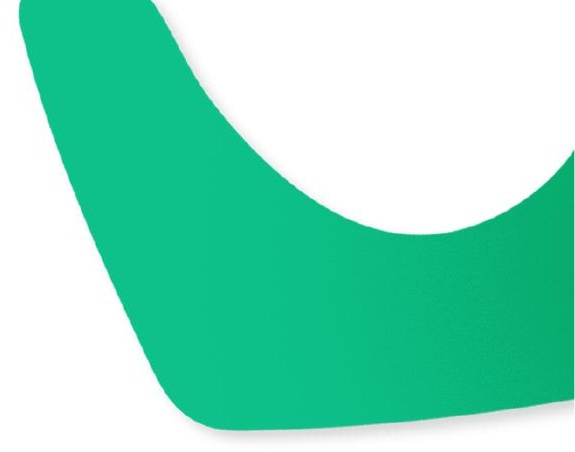





\section{O PROCESSO DE REPRESENTAÇÃO E SIMBOLIZAÇÃO NA EDUCAÇÃO INFANTIL: CONTRIBUIÇÔES PARA O DESENVOLVIMENTO DA LINGUAGEM ESCRITA NA PERSPECTIVA DA PEDAGOGIA HISTÓRICO CRÍTICA}

\section{Vanessa Marinho Cunha Pescarollo Alessandra Salvador Costa Morijo Fabiana Hortolani Sartori}

\section{INTRODUÇÃO}

O presente artigo tem o objetivo de contribuir com a prática do professor de Educação Infantil, visando à investigação da organização do ensino da área da linguagem escrita como promotora do desenvolvimento infantil.

A pesquisa referente a essa prática pedagógica surgiu das observações e inquietações sobre as necessidades das crianças em idade pré-escolar. Tomou-se como eixos articuladores a Pedagogia Histórico Crítica e a Psicologia Histórico Cultural que embasam teoricamente o trabalho educativo do Sistema Municipal de Ensino de Bauru - SP.

Partindo do pressuposto de que a teoria deve subsidiar a prática docente, tornando-se práxis pedagógica no seu sentido objetivo, contraria-se, assim, a visão da educação espontaneísta e sem necessidade de conhecimento científico na Educação Infantil.

Éimportante destacar, o dever da escola deofertar o que é cientificamente constituído, permitindo que 
o aluno acesse o conhecimento mais elaborado, oferecendo capacidade de questionar o senso comum. Para isso, é indispensável o protagonismo do professor, que tem o papel de conhecer para selecionar os conteúdos clássicos ou essenciais que poderão promover o desenvolvimento.

Quando falamos em selecionar conteúdos, é importante destacar três aspectos que devem ser observados: o que ensinar (conteúdo), como ensinar (pedagogia - didática) e a quem ensinar (desenvolvimento do sujeito). Os processos e os meios da educação convergem para a formação humana. Consequentemente, todo o trabalho precisa ser atrelado à capacidade de crescimento humano coletivo.

$234 \quad$ Nesse sentido, as práticas dos professores das crianças de 1 ano e 8 meses a 5 anos e 11 meses são relevantes, pois, envolvem a compreensão do planejamento de ensino da linguagem escrita na Educação Infantil, considerando a periodização do desenvolvimento de acordo com a Teoria Histórico-Cultural.

\section{Educação e a Teoria Histórico-Cultural}

As teorias que respaldam o ensino na Educação Infantil Municipal de Bauru são a Psicologia Histórico-Cultural e a Pedagogia Histórico-Crítica.

Ao conceber a tríade forma-conteúdodestinatário, esquematizada por Lígia Marcia Martins (2013), faz-se necessário aliar psicologia e pedagogia, que constituem, de acordo com 
Pasqualini e Tsuhako (2016), uma orientação à prática pedagógica.

A Pedagogia Histórico-Crítica e a Psicologia Histórico-Cultural compartilham a mesma base filosófica e comungam o mesmo posicionamento ético-político da socialização por meio da escola e do patrimônio humano genérico. Assim, a transmissão intencional dos conhecimentos científicos, ou seja, "o ato de produzir, direta e intencionalmente, em cada indivíduo singular, a humanidade que é produzida histórica e coletivamente pelo conjunto dos homens" (SAVIANI, 2000, p.13), é uma marca dessa corrente de pensamento.

Para Saviani (2000, p. 20), tal Pedagogia defende "o acesso à cultura erudita e à apropriação de novas formas por meio das quais se podem expressar os próprios conteúdos do saber popular". Portanto, há a compreensão de que essa teoria não desconsidera o saber popular, afirmando que, ao se dominar o clássico, consegue-se compreender o popular, mas o contrário não acontece.

Consideram-se a Pedagogia Histórico-Crítica e a Psicologia Histórico-Cultural como teorias que trazem elementos importantes para a constituição de uma escola pública de qualidade. Assim, é fundamental para o trabalho docente dominar a teoria, para que sua prática pedagógica não se paute no fazer por fazer.

O domínio teórico encerra superações importantes, tais como: o fim do espontaneísmo; a crítica necessária às pedagogias do "aprender 
a aprender"; a defesa do ensino sistematizado pelo professor, o que requer clareza de objetivos, conteúdos e encaminhamentos metodológicos; a qualificação da ação pedagógica, não mais pautada no senso comum (ação pedagógica centrada na reprodução do cotidiano); e, por fim, o entendimento da figura do professor como um intelectual em busca de formação sólida e consistente.

O desenvolvimento do psiquismo da criança é dependente das mediações a ela oportunizadas, tendo em vista, que o desenvolvimento é um processo histórico e cultural. As funções psíquicas elementares são comuns aos homens e aos animais, já as funções psíquicas superiores são exclusivamente humanas. Nesse sentido, Elkonin 236 (1969) destaca que o desenvolvimento psíquico das crianças tem lugar no processo de educação e ensino realizado pelos adultos, que é o responsável pela organização da vida da criança, cria condições para seu desenvolvimento e lhe transmite o saber social acumulado historicamente pela sociedade.

Portanto, é necessário entender a concepção de ser humano, educação e desenvolvimento. Isso porque, tudo o que nos define como humanos não chega até nós por meio da genética, mas sim, socialmente, pois, somente o que herdamos biologicamente não nos garante a humanidade.

\section{Um Pouco sobre o Desenvolvimento da Criança}

A criança pequena é refém do meio e de seus estímulos, por isso, são os processos educativos 
que vão mediar a apropriação de instrumentos para o autodomínio da conduta percorrem um caminho do interpsíquico para o intrapsíquico, pela internalização dos signos da cultura.

Martins, Abrantes e Facci (2018) discorrem sobre a Escola de Vigotski e a negação da existência de fases naturais no desenvolvimento infantil, que não são determinadas apenas pela maturação do organismo, mas sim, pela interação da criança com a sociedade e suas atividades. Nessa direção, podemos explicar os períodos do desenvolvimento infantil se nos dedicarmos a observar a sua atividade principal, pois, a medida que a mesma se amplia e se complexifica, promove o desenvolvimento de novas capacidades e funções psíquicas.

A fim de ilustrar o descrito, segue-se a tabela de periodização de autoria do prof. Dr. Angelo Abrantes.

Figura 1: tabela de Periodização do desenvolvimento psíquico PERIODIZAÇÃO DO DESENVOLVIMENTO PSÍQUICO
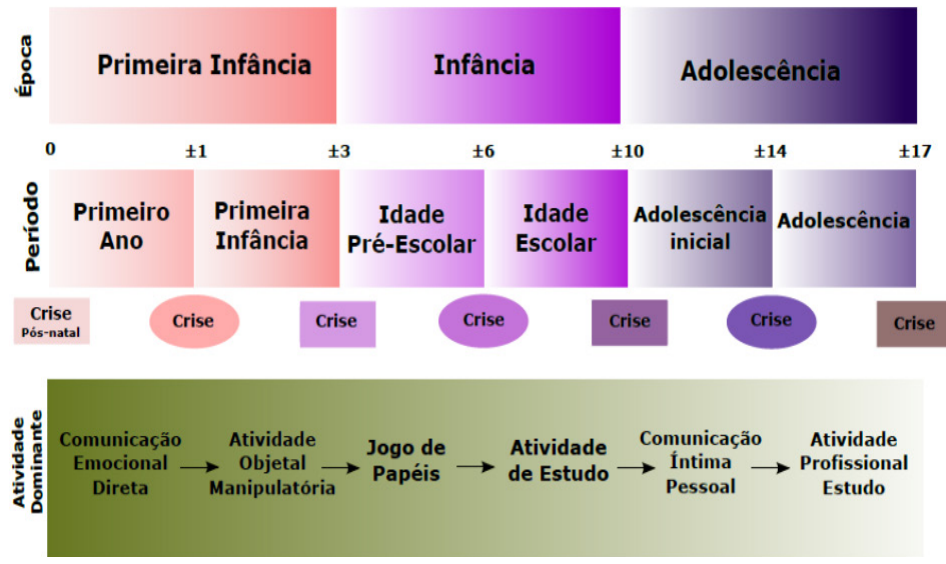


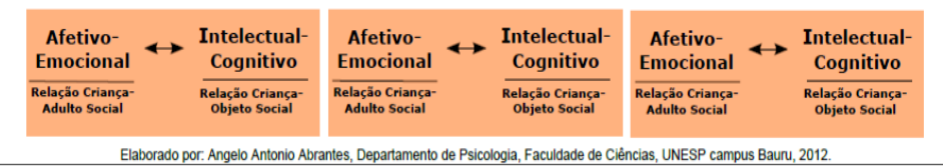

Fonte: Proposta Pedagógica de Educação Infantil (Bauru, 2016)

\section{PrIMEIRA INFÂNCIA}

De acordo com Elkonin (1998), a relação do bebê-adulto é um desenvolvimento dependente da comunicação emocional direta, colocando o adulto responsável por estimular e desencadear novas relações do bebê com o mundo. Ainda podemos elencar a época da Primeira infância em dois períodos que são o primeiro ano ( 0 a 1 ano) e a primeira infância ( 1 anos a 3 anos); relembrando que as idades não são fixas e determinadas, mas sim, aproximadas, dependentes das relações da criança com a sociedade.

Como adultos responsáveis e conscientes do desenvolvimento do bebê, é necessário promover intencionalmente a comunicação direta, como por exemplo, durante os momentos de higiene pessoal, troca ou banho, conversar e interagir com o bebê, provocando reações e interações. Evitando assim, deixar a criança como objeto de ação, enriquecendo e promovendo a comunicação intencionando contribuir para o desenvolvimento, retirando os bebês da passividade.

Progressivamente a criança desenvolve a autonomia e percepção e na primeira infância, já se encontra na manipulação dos objetos, dando 
início as brincadeiras de papéis, atividade principal do período pré-escolar.

\section{INFÂNCIA}

A infância pode ser dividida em Idade Préescolar e Idade Escolar, nos concentraremos em estudar o período da Educação Infantil que é aproximadamente até 5 anos e 11 meses.

Leontiev (1988), explica sobre surgimento e carência da criança de compreender o mundo dos adultos. É "a partir de sua necessidade de agir em relação não apenas ao mundo dos objetos diretamente acessíveis a ela, mas também, em relação ao mundo dos adultos".

Outrossim, a atividade principal da criança no período Idade pré-escolar é o jogo de papéis. Ao brincar de representar os adultos e suas atividades, a criança tenta compreender, e, para isso, ela desenvolve o autocontrole da conduta, sendo a sua principal conquista neste período. Ao reproduzir as ações do adulto, exemplo agir como mamãe, ela tem que controlar suas ações e vontades para desempenhar o papel.

\section{O Processo de Representação \\ e Simbolização na Educação Infantil}

A linguagem possui papel fundamental no desenvolvimento do psiquismo infantil. Pois, quando a criança se apropria da mesma, passa a se relacionar com o meio em que vive mais amplamente, conseguindo reorganizar ações e pensamentos. 
Assim, a linguagem passa a ser determinante no desenvolvimento dos processos superiores.

Na sequência, abordaremos o simbolismo do brinquedo e o desenho infantil, atividades que promovem o desenvolvimento da criança quando devidamente orientadas.

Sob a perspectiva Histórico-cultural, o pensamento e a linguagem passam a se conectar no momento que a criança consegue olhar para o objeto e compreendê-lo como tal. Após essa fase, a criança começa a fazer suas primeiras representações, substituindo a função real do objeto por outra imaginada. Essas representações são decisivas para o desenvolvimento do simbolismo. Mas, para chegar a esse ponto, o objeto em si 240 passou por um caminho de simbolização.

Ao pensar no real e transformá-lo no simbólico, a criança transcorre um caminho de experimentação que começa com a apresentação do objeto pelo adulto, quando ela utiliza seus sentidos para compreender e assimilar melhor o objeto, explorando-o e manipulando-o. Cabe ao adulto mais experiente demonstrar o nome, a função real e as características peculiares do objeto. Nesse processo, a fala e a mediação são fundamentais para a compreensão da criança, que passa a explorar o mundo pela percepção, sentidos e vivências com os objetos. Tais experiências são primordiais para que ela possa desenvolver o simbolismo do objeto, já que, na brincadeira simbólica, o objeto é "transformado" por seu simbolismo. 
Figura 1: jogos de papéis

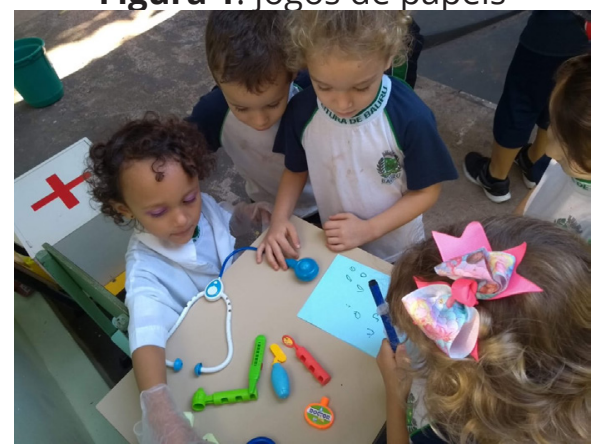

Fonte: arquivo pessoal

Semelhantemente, destaca-se aqui, a importância dos primeiros desenhos, tendo em vista que, ao fazê-los, a criança tenta explicar com gestos o que está demonstrado no seu desenho. Logo, os rabiscos registrados podem ser vistos como complementares aos gestos da criança.

Figura 2 e 3: gestos escritos

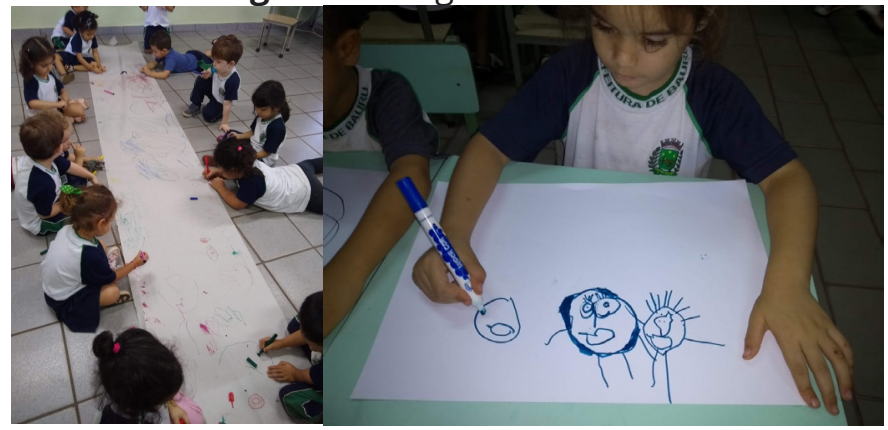

Fonte: arquivo pessoal

Nessa linha de raciocínio, temos que defender o direito da criança se expressar pelo desenho, e com 
isso, demonstrar a importância de o professor estar atento à periodização do desenvolvimento infantil, ofertando-lhe meios para o desenvolvimento do desenho com diversos tipos de suportes, riscadores e outros meios, para promoção dessa linguagem.

Figuras 4,5 e 6: intervenções com suportes e riscadores
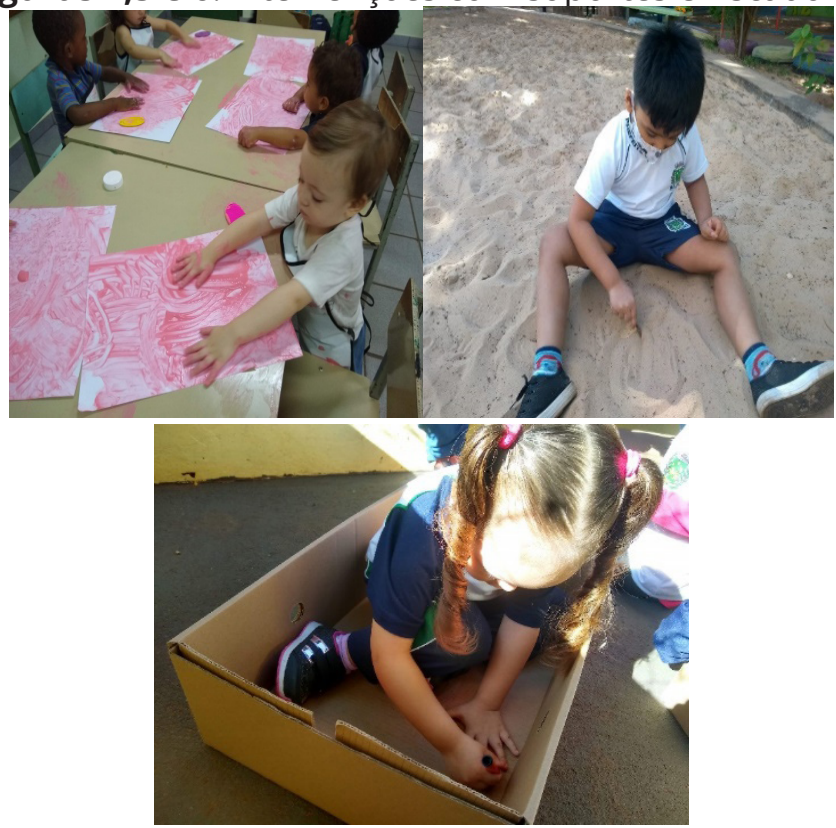

Fonte: arquivo pessoal

Inicialmente a criança risca o papel pelo prazer de rabiscar. Segundo Mèridieu (1974) apud Derdyk (2020, p. 44) "o primeiro espaço gráfico da criança é a projeção do corpo sobre o papel". Assim, o princípio das marcas sobre o papel e outros suportes constituem-se em garatujas 
desordenadas, com traços desordenados, casuais, caóticos em todas as direções.

Figura 7: primeiros rabiscos

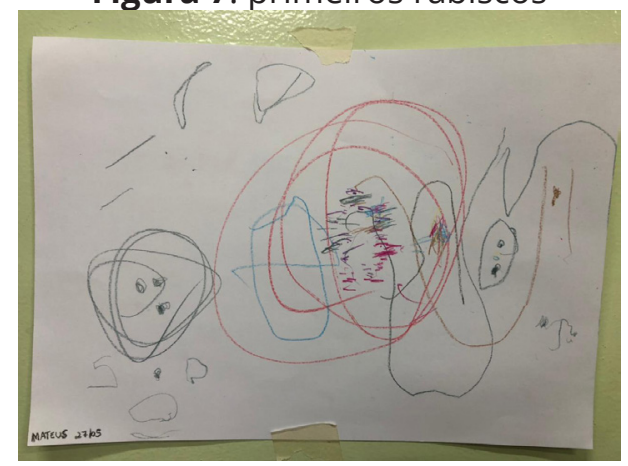

Fonte: arquivo pessoal

Num segundo momento, surge a garatuja em si, em que podemos observar um início de controle motor, pois a criança compreende melhor o suporte e sua extensão, além de controlar seu marcador a ponto de começar a fechar círculos.

Figura 8: fechamento de círculo

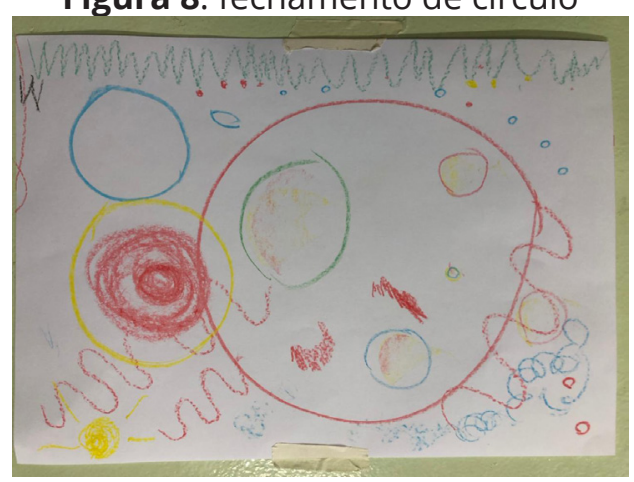

Fonte: arquivo pessoal 
Já num terceiro momento surge a apresentação da figura humana de maneira primitiva, com fechamento de círculos, ação possível graças a movimentos anteriores.

Figura 9: figura humana primitiva

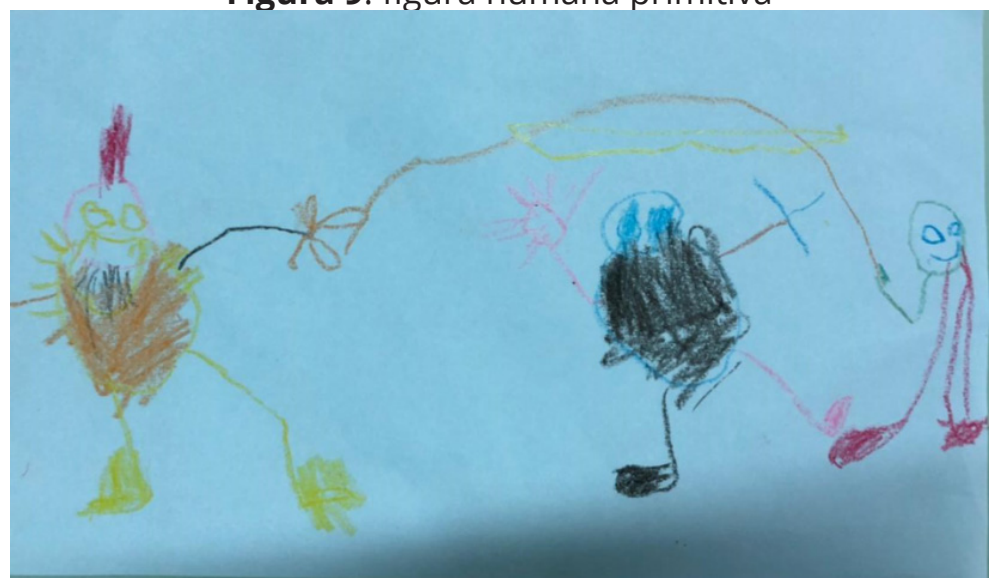

Fonte: arquivo pessoal

Em um quarto momento surge o torso na figura humana, o que denota evolução conceitual. Esse desenho segue um processo contínuo em que a criança adquire noção do próprio corpo e do corpo de seus pares. Nessa mesma sequência, ocorre a figuração de animais e personagens juntamente com o desenho principal, surgindo desenhos mais ricos e cheios de detalhes. Ainda aparece a visão interior dos objetos, corpos, casas, entre outros, iniciando-se a percepção tridimensional dos objetos e pessoas. 


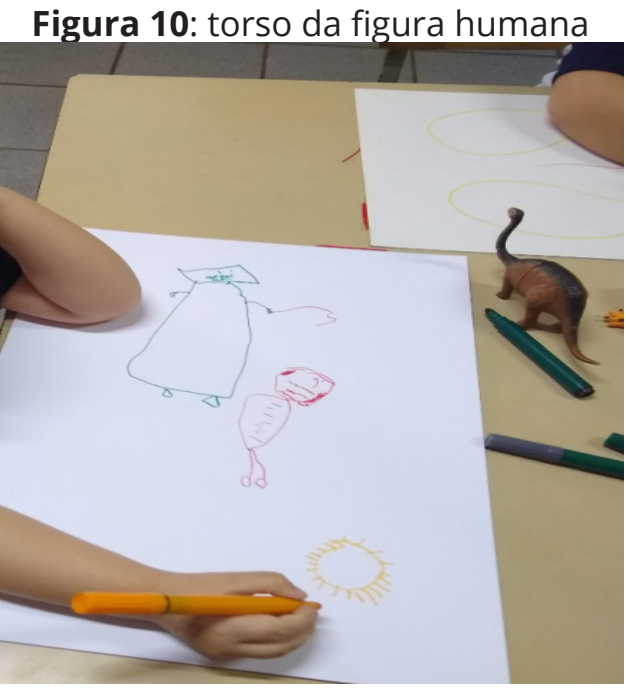

Fonte: arquivo pessoal

Todo esse processo, quando devidamente mediado pode chegar ao aprimoramento das fontes estéticas já na adolescência.

Pelo exposto, compreende-se que a escrita passa por uma fase pictográfica em que a experiência do desenho, de acordo com Vigotski, Luria e Leontiev (2010), "inicialmente [...] é brincadeira, um processo autocontido de representação; em seguida, o ato completo pode ser usado como estratagema, um meio para o registro". Os autores salientam, que por ser uma função psicológica da cultura humana, a escrita não se desenvolve de maneira linear e sim, possui crescimento e desenvolvimento contínuos, cujo início não tem idade determinada, mas o término coincide com marco final da alfabetização. 
Nesse sentido, o desenho dá oportunidades de a criança se expressar.

As relações entre desenho e gesto contam ainda com o jogo de papéis, que é fundamental no desenvolvimento do simbolismo, até que a criança em um contínuo, consiga pela mediação de seu professor atingir a abstração da escrita. A criança passa pelo gesto, a atribuir a um mesmo objeto várias funções. Por exemplo, um galho pode representar um pente, e depois, em outra brincadeira, uma mamadeira.

Como professores, podemos promover em nossas crianças a necessidade, o sentido e o desejo de escrever. Segundo Leontiev (1978), para que a atividade seja realizada, devem ser 246 despertados na criança o sentido e o significado, caso contrário, a escrita será apenas um gesto mecânico. De acordo com a vertente teórica de Vigotski, podemos também, na Educação Infantil, nos valer dos gêneros discursivos, que são instrumentos para a comunicação. Por possuírem diferentes linguagens, os gêneros discursivos afetam a imaginação humana, alavancando as funções psíquicas superiores e promovendo o desenvolvimento humano e cultural.

Segundo Dolz, Noverraz e Schneuwly (2004, p.97), os gêneros discursivos "ajudam o aluno a dominar melhor um gênero, permitindo assim, escrever ou falar de maneira mais adequada numa dada situação de comunicação". Sugerem, 
portanto, que o ensino da língua deve ser mediado por gêneros e que, ao mesmo tempo em que a criança se apropria dos gêneros, internaliza a linguagem e suas práticas, compreendendo assim muito melhor sua própria língua.

De acordo com Vigotski (2000), ao ensinar a escrita, o professor costuma desconsiderar o objeto de conhecimento linguagem escrita e a forma como se dá sua apropriação pelo sujeito:

La historia del desarrollo de la escritura se inicia cuando aparecen los primeros signos visuales en el niño y se sustenta en la misma historia natural del nacimiento de los signos de los cuales ha nacido el lenguaje. El gesto, precisamente, es el primer signo visual que contiene la futura escritura del niño igual que la semilla contiene al futuro roble. El gesto es la escritura en el aire y el signo escrito es, frecuentemente, un gesto que se afianza11 (VYGOTSKI, 2000, p. 186).

Sob a perspectiva da Psicologia Histórico-Cultural, a escrita vai muito além do domínio pela criança das letras e alfabeto, conforme escreve Vygotsky (2000,

$11 \mathrm{~A}$ história do desenvolvimento da escrita se inicia quando aparecem os primeiros signos visuais na criança e se sustenta na mesma história natural do nascimento dos signos dos quais há nascido a linguagem. O gesto; precisamente, é o primeiro signo visual que contém a futura escrita da criança, igual a semente da árvore que contém a futura árvore. $\mathrm{O}$ gesto é a escrita no ar e o signo escrito é, frequentemente, um gesto que se fixa. (VYGOTSKY, 2014, p. 186, tradução nossa). 
p.279): “El desarrollo del linguaje reestructura el pensamiento, le confiere nuevas formas"12.

\section{Considerações Finais}

O presente estudo mostrou que o professor precisa conhecer a criança a ser ensinada e a forma como se dá o processo de ensino e aprendizagem da linguagem escrita, levando-se em conta como a criança se apropria das objetivações humanas. $\mathrm{Na}$ mesma direção, evidenciou-se que é relevante que o docente consiga estabelecer generalizações para ser capaz de articular teoria e prática, configurandose, assim, a práxis pedagógica.

No tocante ao planejamento intencional foi possível, por meio da exposição de ações docentes 248 planejadas e mediadas, a compreensão de que a Educação Infantil não é lugar do senso comum. Logo, é preponderante a inserção desde a mais tenra idade, de ações pedagógicas planejadas e fundamentadas no conhecimento científico. Assim, é possível ampliar a aprendizagem e desenvolvimento infantil, enriquecendo o cotidiano da criança pequena com trabalho educativo não cotidiano.

Verificou-se que um planejamento intencional deve ter como fundamentos o conhecimento sobre a quem se destina o ensino, os conteúdos e a melhor forma de ensinar. Para tanto, faz-se necessário o conhecimento docente sobre as fases do desenvolvimento infantil e a atividade guia 12 "O desenvolvimento da linguagem reestrutura o pensamento, dá-Ihe novas formas" (VYGOTSKY, 1995, p. 279, tradução nossa) 
dominante, a fim de que ocorra a promoção de aprendizagem e avanços.

Semelhantemente, a linguagem e os processos de simbolização não transcorrem naturalmente, necessitam de intervenções e mediações planejadas e intencionais, a fim de que, a criança se aproprie do sistema de escrita e do conhecimento material e imaterial, que cultural e historicamente é produzido pelo coletivo da humanidade.

Desse modo, espera-se que este trabalho possa contribuir para a ampliação do conhecimento e a conscientização a respeito do papel preponderante do professor e sua práxis educativa. Sendo assim, primordial ao professor de Educação Infantil, o entendimento de como se dá esse processo, levando em conta a criança e seus períodos do desenvolvimento, bem como, o que se pretende ensinar e o processo de apropriação da criança.

\section{REFÊRENCIAS}

Derdyk, Edith. Formas de pensar o desenho: desenvolvimento do grafismo infantil. São Paulo: Panda Educação, 2020.

DOLZ, Joaquim; NOVERRAZ, Michele; SCHNEUWLY, Bernard. Seqüências didáticas para o oral e a escrita: apresentação de um procedimento. In: SCHNEUWLY, Bernard.; DOLZ, Joaquim. e colaboradores. Gêneros orais e escritos na escola. [Tradução e organização: Roxane Rojo e Glaís Sales Cordeiro]. Campinas-SP: Mercado de Letras, 2004. Pedagogia histórico-crítica: primeiras aproximações/Dermeval Saviani 11.ed.rev.- 
Campinas, SP: Autores Associados, 2011. - (Coleção educação contemporânea).

ELKONIN, D. B. Desarrollo psíquico de los ninos. In. SMIRNOV, A. A; (Org). Psicologia. Traducción por Florencio Villa Landa.3. Ed. México. Editora Grijalbo, 1969.

ELKONIN, D. B. Psicologia do jogo. São Paulo: Martins Fontes, 1998.

LEONTIEV, A. Uma contribuição à teoria do desenvolvimento da psique infantil. In: VIGOTSKII, L. S. et al. Linguagem, desenvolvimento e aprendizagem. São Paulo: Ícone/Edusp, 1988.

LEONTIEV. Alexis, N.. O desenvolvimento do psiquismo. Lisboa: Horizonte Universitário, 1978.

MARTINS, L. M. O desenvolvimento do psiquismo e a educação escolar: contribuições à luz da psicologia histórico-cultural e da pedagogia histórico crítica. 250 Campinas: Autores Associados, 2013.

MARTINS, L. M.; ABRANTES, A. A.; FACCI, M. G. D. Periodização histórico-cultural do desenvolvimento psíquico: do nascimento à velhice. Campinas, SP: Autores Associados, 2020.

PASQUALINI, J. C.; TSUHAKO, Y. N. Proposta pedagógica para a Educação Infantil do Sistema Municipal de Ensino de Bauru/SP [recurso eletrônico], orgs. Bauru: Secretaria Municipal de Educação, 2016.

SAVIANI, D. Pedagogia Histórico-Crítica: primeiras aproximações. 8 ed. Campinas: Autores Associados, 2000. VIGOTSKII, L. S.; LURIAA. R.; Leontiev, A. N. Linguagem, Desenvolvimento e Aprendizagem/ Luria, $-11^{\text {a }}$ edição - São Paulo: ícone, 2010.

VIGOTSKII, L. S Historia del desarrollo de las funciones psíquicas superiores. In: Obras Escogidas III. Madrid, Espanha: Visor, 2000. 


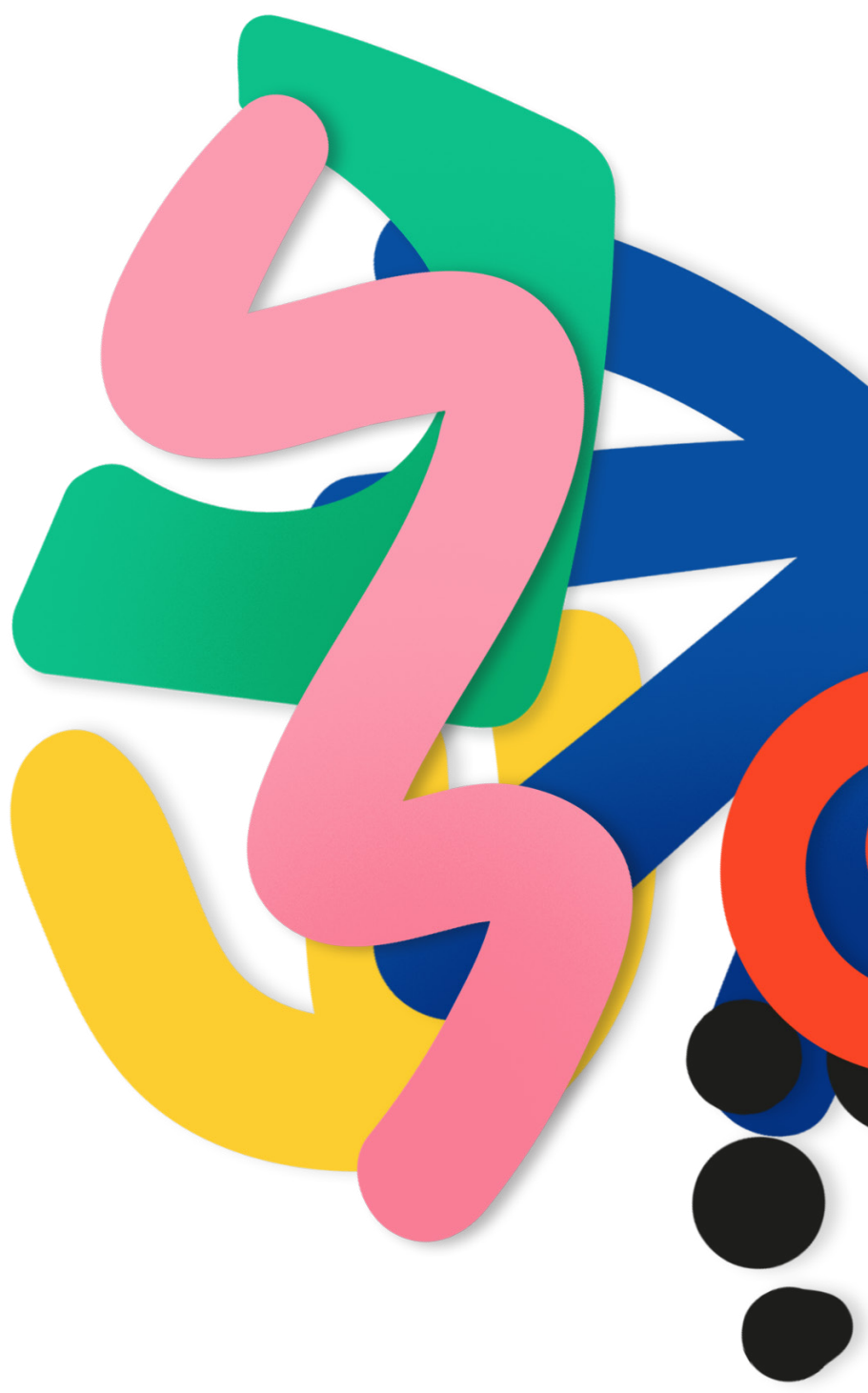





\section{UM OLHAR SOBRE A FLORA DO DISTRITO DE TIBIRIÇÁ: \\ REPRESENTANDO A VEGETAÇÃO POR MEIO DA ARTE}

Josilaine Aparecida Pianoschi Malmonge Lígia Maria Ramazzini Remaeh Sintia Otuka Rossi Vanessa Marinho Cunha Pescarollo

INTRODUÇÃO

Preservar a natureza faz parte do diálogo das crianças na educação Infantil. Elas apresentam um carinho especial pelas plantas e animais. Isso desperta nas crianças curiosidades e dúvidas às quais, na maioria das vezes, elas procuram sanálas na escola.

O mundo onde as crianças vivem se constitui em um conjunto de fenômenos naturais e sociais indissociáveis diante do qual elas se mostram curiosas e investigáveis. Desde muito pequenas, pela interação com o meio natural e social no qual vivem, as crianças aprendem sobre o mundo, fazendo perguntas e procurando respostas às suas indagações e questões (BRASIL, 1998, p. 163).

A proposta então, é compreender como o ensino de ciências pode ser vivenciado por meio da arte, utilizando para isso também, o desenvolvimento dos sentidos. 
Nessa direção, durante o ano de 2019, as crianças do Infantil $V$, agrupamento de idades entre 4 e 5 anos, da Escola de Educação Infantil Angélica Leite de Freitas foram incentivadas a conhecer a flora do distrito de Tibiriçá, local onde a escola está localizada, fazendo com que as crianças se sentissem responsáveis pelo cuidado e preservação da natureza. Semelhantemente, essa prática teve a intenção de propiciar o desenvolvimento artístico dos pequenos, pois, ao observar a flora as crianças realizaram a pintura das plantas, e isso fez com que elas deixassem de fazer desenhos estereotipados, pois tiveram oportunidades de diferenciar árvores e aprender sobre suas partes: troncos, folhas, flores, frutos e demais especificidades.

É tarefa do ensino de Artes Visuais, portanto, assegurar que as crianças vivam intensas experiências, estabelecendo relações entre diferentes modos de utilização dos elementos visuais (sintaxe visual), sendo capazes de decodificar e interpretar composições (recepção/leitura) e de compor com elas (criação) (PASQUALINI. TSUHAKO 2016, p. 462).

Com o objetivo de compreender a existência de diferentes espécies da flora no distrito de Tibiriçá e representa-las por meio da pintura, foram planejadas e realizadas uma sequência de ações envolvendo observação, exploração, pesquisa e criação. 
Esse relato de experiência é de cunho qualitativo e possui característica de pesquisa-ação, tendo em vista que:

A pesquisa-ação, em outras palavras, abarca um processo empírico que compreende a identificação do problema dentro de um contexto social e/ou institucional, o levantamento de dados relativos ao problema e, a análise e significação dos dados levantados pelos participantes. Além da identificação da necessidade de mudança e o levantamento de possíveis soluções, a pesquisa-ação intervém na prática no sentido de provocar a transformação. Coloca-se então, como uma importante ferramenta metodológica capaz de aliar teoria e prática por meio de uma ação que visa à transformação de uma determinada realidade (Koerich, 2009).

Para a viabilização de cada ação desenvolvida houve um diagnóstico dos saberes prévios das crianças, para assim, formular as estratégias.

\section{DesenVolvimento}

O trabalho foi desenvolvido num período de nove meses, na Escola de Educação Infantil Angélica Leite de Freitas, distrito de Tibiriçá, município de Bauru, com a turma do Infantil V, com um total de 21 crianças.

Tibiriçá, município de Bauru, possui aproximadamente 1500 habitantes, com uma área 
total de $87,8 \mathrm{~km}^{2}$, sendo assim, relativamente pequeno. Semanalmente, era proposto um passeio para observar, explorar e conhecer uma das árvores do local.

A criança é curiosa pelo mundo a sua volta e aprende a explorar, cada vez mais, o meio que a rodeia, além de possuir habilidade para compreender e utilizar a linguagem, proporcionando a existência do diálogo.

De acordo com o Referencial Curricular Nacional para a Educação Infantil - RCNEI:

A criança como todo ser humano, é um sujeito social e histórico e faz parte de uma organização familiar que está inserida em uma sociedade, com uma determinada cultura, em um determinado momento histórico. É profundamente marcada pelo meio social em que se desenvolve, mas também o marca (BRASIL, 1998, pg.21).

Éfundamental que o professor estabeleçaobjetivos e ofereça mediações durante a realização das tarefas propostas, tendo em vista, o desenvolvimento das funções psíquicas e capacidades estéticas da criança, sempre de modo lúdico e inventivo (PASQUALINI;TSUHAKO, 2016, p. 464).

De acordo com Brasil (1998, p. 166) é importante que as crianças tenham contato com diferentes elementos, fenômenos e acontecimentos do mundo, sejam instigadas por questões significativas 
para observá-los e tenham acesso a modos variados de compreendê-los e representá-los.

No cotidiano escolar o professor deve organizar estudos de aprendizagem, a partir de questões desafiadoras que estimulem a curiosidade dos alunos. É necessário:

Organizar as situações de aprendizagem partindo de questões que sejam desafiadoras e, reconhecendo a diversidade cultural, estimulem $\mathrm{o}$ interesse e a curiosidade científica dos alunos e possibilitem definir problemas, levantar, analisar e representar resultados; comunicar conclusões e propor intervenções (BRASIL, 2017, p. 320).

A aprendizagem ocorre quando a criança vê sentido no que está fazendo, no que está aprendendo. L'ecuryer (2015, p.145) salienta:

Podemos ensinar às crianças uma série de conceitos, de nomes de coisas, enchêlas de dados como se fossem maquinas inteligentes, mas, se não conseguirmos que o preâmbulo desse conhecimento tenha como origem a curiosidade, não somente a aprendizagem não será sustentável, como não terá sentido.

Para mobilizar os sentidos, é "essencial o enriquecimento de experiências, promovendo encontros com diferentes linguagens" (OSTETTO, 2010) 
Ao ensinar os conteúdos da área de Ciências da Natureza cabe ao professor:

Oferecer oportunidades para que eles, de fato, envolvam-se em processos de aprendizagem nos quais possam vivenciar momentos de investigação que Ihes possibilitem exercitar e ampliar sua curiosidade, aperfeiçoar sua capacidade de observação, de raciocínio lógico e de criação, desenvolver posturas mais colaborativas e sistematizar suas primeiras explicações sobre o mundo natural e tecnológico, e sobre seu corpo, sua saúde e seu bem-estar, tendo como referência os conhecimentos, as linguagens e os procedimentos próprios das Ciências da Natureza (BRASIL, 2017, p.329).

No cotidiano escolar é importante que o professor proponha ações que desafiem a criança a refletir, questionar, levantar suas hipóteses, maximizando a sua curiosidade, para que cada vez mais ela tenha desejo em aprender. Além da curiosidade para motivar-se na aprendizagem, é necessário que haja uma preocupação que esta seja conduzida de forma segura, a fim de oportunizar à criança formular suas próprias respostas.

Para o ensino de Artes visuais é essencial propor atividades de observação sensível do entorno e também pesquisas sensoriais (diferentes sensações proporcionadas pela manipulação de materiais e suportes diversos). O ambiente em que a criança está inserida deve ser considerado pelo professor, 
como enfatiza as autoras Ferraz e Fusari (2009, p. 38) que "[...] a educação em arte não acontece no vazio, nem desenraizadas das práticas sociais vividas pela sociedade como um todo".

$\mathrm{Na}$ Educação Infantil o ensino de ciências é fundamental para a aproximação aos conceitos científicos, desenvolvendo a criticidade e o vocabulário. A arte apresenta-se com o mesmo grau de importância, havendo assim, a possibilidade de articular os conteúdos dessas áreas. Santos et al (2019) ressalta que "associar arte e ciência na construção de saberes é o mesmo que associar razão e emoção, objetividade e sensibilidade, lógica, intuição e criação".

As ações realizadas durante o projeto se deram em espaços não-formais, como o entorno e ruas do bairro onde a escola está inserida.

De acordo com Brasil (2017):

Valorizar a diversidade de saberes e vivências culturais e apropriar-se de conhecimentos e experiências que lhe possibilitem entender as relações próprias do mundo do trabalho e fazer escolhas alinhadas ao exercício da cidadania e ao seu projeto de vida, com liberdade, autonomia, consciência crítica e responsabilidade.

Os saberes prévios das crianças foram identificados por meio de rodas da conversa e de uma pintura inicial, com a proposta de que eles representassem árvores e flores. Esse diagnostico 
possibilitou identificar quais plantas as crianças conheciam e também como as mesmas as ilustravam. Cerca de $80 \%$ das crianças desenham árvores estereotipadas. Klisys (2010, p. 33) cita que:

Do ponto de vista da didática, o que parece haver em comum entre diversos trabalhos realizados em Ciências é o levantamento dos conhecimentos prévios das crianças. Elas só aprendem o que possui significado para elas, quando conseguem estabelecer relações entre o que já sabem e o que ainda lhes é novo como conhecimento.

Semanalmente caminhava-se pelas ruas do distrito para conhecer uma árvore que era selecionada previamente pela professora, a fim de que a mesma tivesse propriedade e informações sobre aquela espécie, no sentido de sanar possíveis dúvidas e curiosidades dos alunos.

Figura 1: Dialogo com os estudantes sobre a Paineira (Ceiba speciosa)

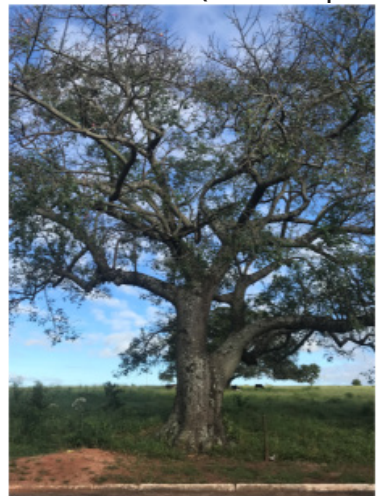




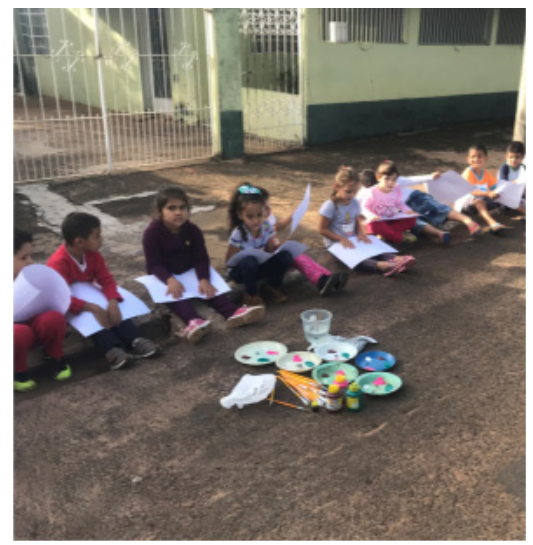

Fonte: Arquivo pessoal da pesquisadora (2019).

Sentados próximo a árvore escolhida, era dialogado sobre o seu nome, tipo de caule, folhas, flores e outras curiosidades. Os alunos tocavam as partes da planta, percebendo texturas e formas e, posteriormente, cada grupo de crianças usavam tintas para representa-la por meio da pintura.

Figura 2: Conhecendo as características da árvore

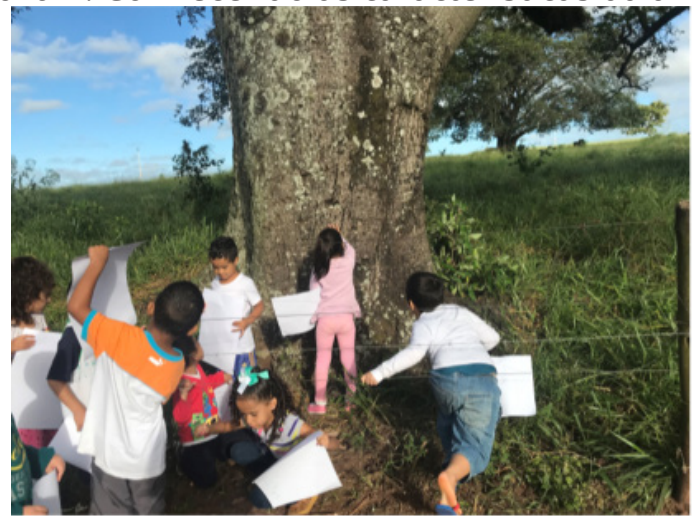

Fonte: Arquivo pessoal da pesquisadora (2019). 
Por meio do trabalho com arte é possível explorar a imaginação e a criatividade dos estudantes, além de favorecer a sua expressão e representação do mundo. De acordo com (FERRAZ e FUSARI, 2009, p.18):

É fundamental entender que a arte se constitui de modos específicos de manifestação da atividade criativa dos seres humanos, ao interagirem com o mundo em que vivem, ao se reconhecerem, e ao conhecê-lo. Em outras palavras, o valor da arte está em ser um meio pelo qual as pessoas expressam, representam e comunicam conhecimentos e experiências. A atividade de desenhar para as crianças, por exemplo, é muito importante, pois favorece a sua expressão e representação do mundo.

Figura 3: Representando a flora por meio da pintura

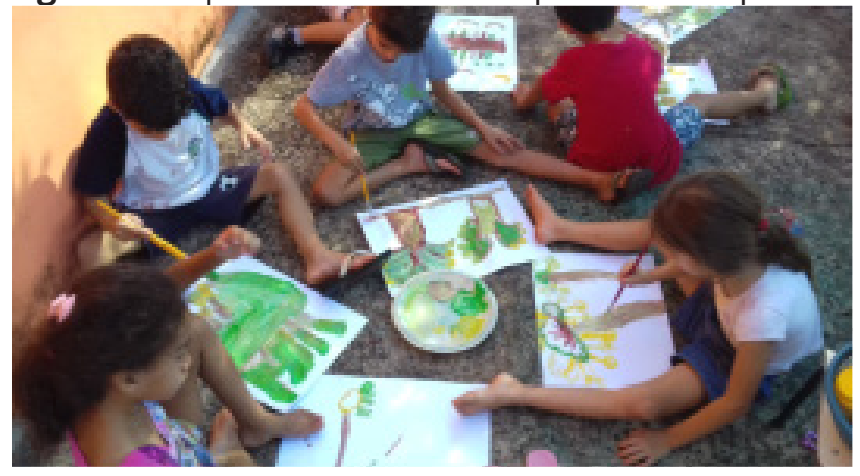




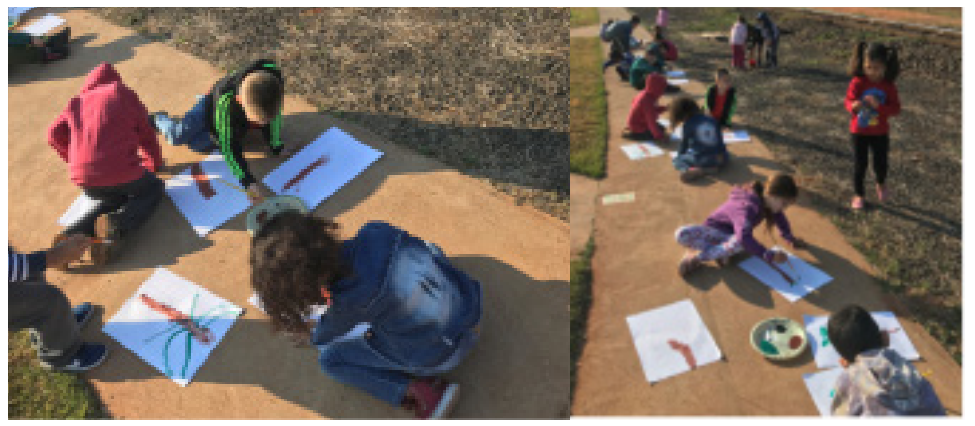

Fonte: Arquivo pessoal da pesquisadora (2019).

A pintura é uma atividade produtiva, segundo Pasqualini e Tsuhako (2016)“isso cria condições para o desenvolvimento da capacidade de planejamento da ação, fundamental para a formação das formas superiores de atividade humana."

De acordo com Cunha (1999) "expressar não é responder a uma solicitação de alguém, mas mobilizar os sentidos em torno de algo significativo, dando uma outra forma ao percebido e vivido. "

Por intermédio do desenho a criança media a vivência do cotidiano com suas experiências e fantasias, como descreve Arouca (2012, p.39) “ensinar a representar por meio de imagens é ensinar a reorganizar o mundo a partir do seu ponto de vista"

Após a pintura, era realizado a coleta de sementes, folhas e flores, presentes próximo ao local onde estava a árvore, com o objetivo de compor a coleção da turma. Mensalmente era proposto atividade de exploração e criação com os elementos presentes na coleção. 
Partindo de coleções, é possível brincar e observar, texturas, linhas e desenhos de frascos, latas, retalhos de tecidos, flores, que trazem diferentes formas; carimbar com a sola do calçado no papel para observar as marcas; propor que acriança desenhe e desmanche usando palitos, pedras gravetos, folhas de plantas e árvores, contas, barbantes, correntes; desenhar com gravetos em caixas de areia ou no chão; construir jogo da memória com as próprias garatujas; desenhar linhas tristes, alegres, rebolantes, bravas, etc (PASQUALINI; TSUHAKO, 2016, p.480).

Figura 4:- Criando com elementos da natureza
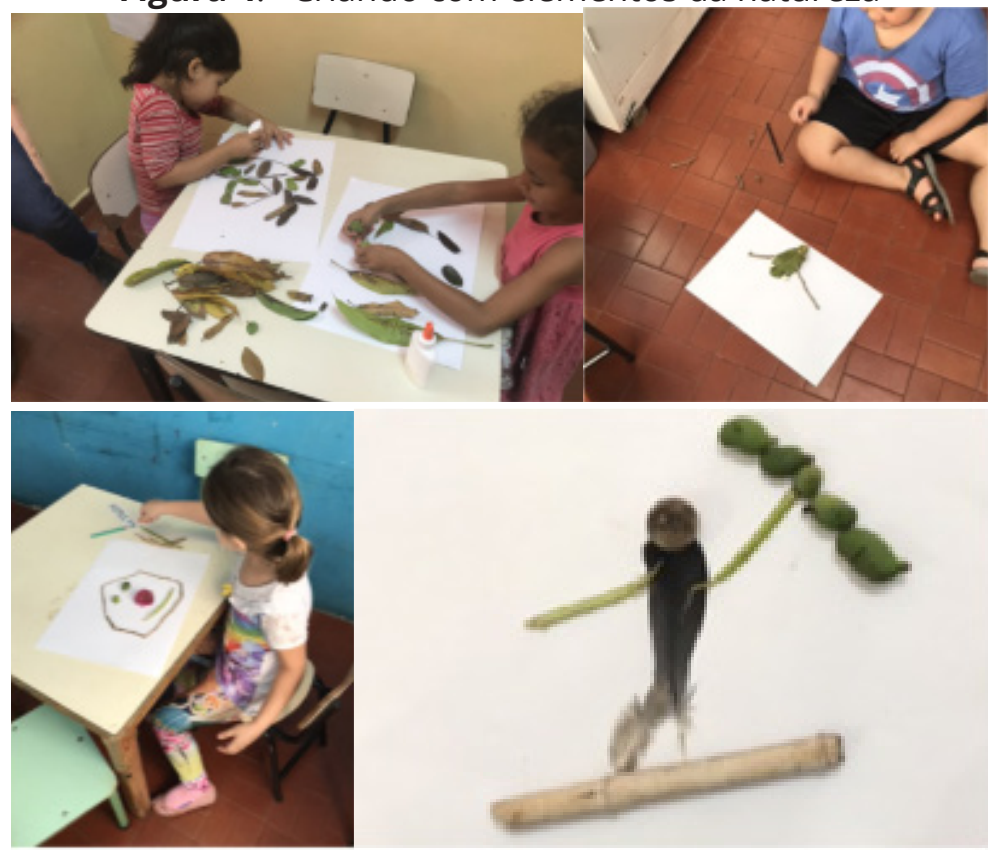


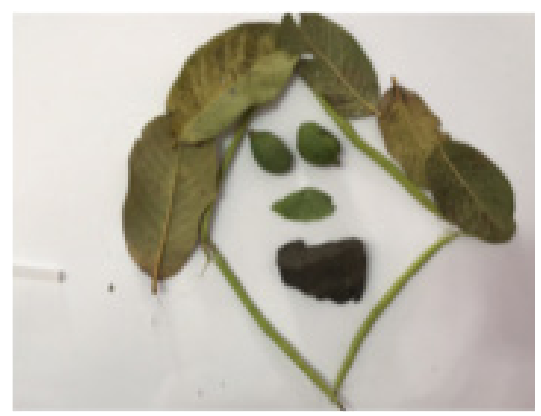

Fonte: Arquivo pessoal da pesquisadora (2019).

A cada ação desenvolvida (pintura das árvores, criação com elementos da natureza) era possível perceber o desenvolvimento das crianças. Não apenas pelo fato de seus desenhos e pinturas estarem mais elaborados, mas também, pela interação social, dialogo entre os pares, expressão corporal, melhora das habilidades motoras, desenvolvimento da atenção e memória

No trabalho educativo é necessário que a aprendizagem faça haja sentido para o aluno, nesse processo a informação deverá interagir com os conceitos que os alunos já sabem. Essas serão assimiladas, diferenciadas, integrarão novos conceitos, facilitando assim novas aprendizagem.

\section{Considerações Finais}

O trabalho na Educação Infantil sobre a flora do distrito de Tibiriçá com as crianças do agrupamento Infantil $V$, fez com que elas fossem instigadas a observar as árvores do local onde a escola está inserida, diferenciando as suas características e 
percebendo como é importante tê-la no ambiente. É essencial incentivar as crianças a colocarem em prática sua imaginação, assim, será despertado suas emoções e sentimentos.

Houve um progresso no desenvolvimento das crianças em relação a pintura e também ao desenho. Percebeu-se que as representações de árvores em seus desenhos e pinturas passaram a ressaltar características e detalhes das árvores, superando as figuras estereotipadas, comuns nas criações iniciais. Além do progresso em relação a pintura e ao desenho houve o desenvolvimento global das crianças, visto que, as mesmas apresentaram ampliação nas habilidades motoras, na atenção e memoria, além da interação social.

266 Mediante as ações propostas foi possível perceber a importância da elaboração de atividades baseadas no cotidiano da criança, considerando os elementos naturais e/ou culturais, estimulando assim o desenvolvimento da percepção através dos sentidos: ver, sentir, ouvir e tocar.

Do mais, espera-se que esse trabalho possa contribuir para a prática pedagógica, onde os professores deem sentido e direção às práticas educacionais, assegurando a intencionalidade da ação proposta, visando a formação do educando.

\section{REFERÊNCIAS}

\section{AROUCA, C. A. C. Arte na escola: como estimular um olhar curioso e investigativo nos alunos dos}


anos finais do ensino fundamental. São Paulo: Editora Anzol, 2012.

BRASIL. Base Nacional Comum Curricular (BNCC). Segunda versão revista. Brasília, MEC/ CONSED/UNDIME, 2017. Disponível em: < http:// portal.mec.gov.br/index.php?option=com docman\&view=download\&alias=79601-anexo-textobncc-reexportado-pdf-2\&category_slug=dezembro2017-pdf\&Itemid=30192> . Acesso em: 07 mai. 2020.

BRASIL. Ministério da Educação e do Deporto. Referencial Curricular Nacional para a Educação Infantil. Secretaria de Educação Fundamental. Brasília: 1998. V. 3.

CUNHA, S. R. V. Pintando, bordando, rasgando, desenhando e melecando na educação infantil. In: CUNHA, S. R. V. da (Org.). Cor, som e movimento. Porto Alegre: Mediação, 1999. p. 7-36.

FERRAZ, M. H. C. T.; FUSARI, M. F. R. Arte na educação escolar. $4^{a}$ ed. São Paulo: Cortez, 2010. FERRAZ, Maria Heloisa C. de T.; FUSARI, Maria F. de Resende. Metodologia do ensino da arte: fundamentos e preposições. São Paulo: Cortez, 2009.

KLISYS, A. Ciência, arte e jogo: projetos e atividades lúdicas na educação infantil. São Paulo: Petrópolis, 2010.

L'ECUYER, C. Educar na curiosidade: A criança como protagonista da sua educação. São Paulo: Edições Fons Sapientiae, 2015.

OSTETTO, L. Educação Infantil Saberes e Fazeres da Formação de Professores. São Paulo. Editora: Papirus. 2010

PASQUALINI, J. C.; TSUHAKO, Y. N. Proposta pedagógica para a Educação Infantil do Sistema Municipal de Ensino de Bauru/SP [recurso eletrônico], orgs. Bauru: Secretaria Municipal de Educação, 2016. 
SANTOS, A. G.; Silva, M. G. S. O ensino de ciências através da arte: peça heróis da ciência. Anais VI CONEDU. Campina Grande: Realize Editora, 2019. Disponível em: <http://www.editorarealize.com.br/ artigo/visualizar/61333>. Acesso em: 30 de jun. 2021. 


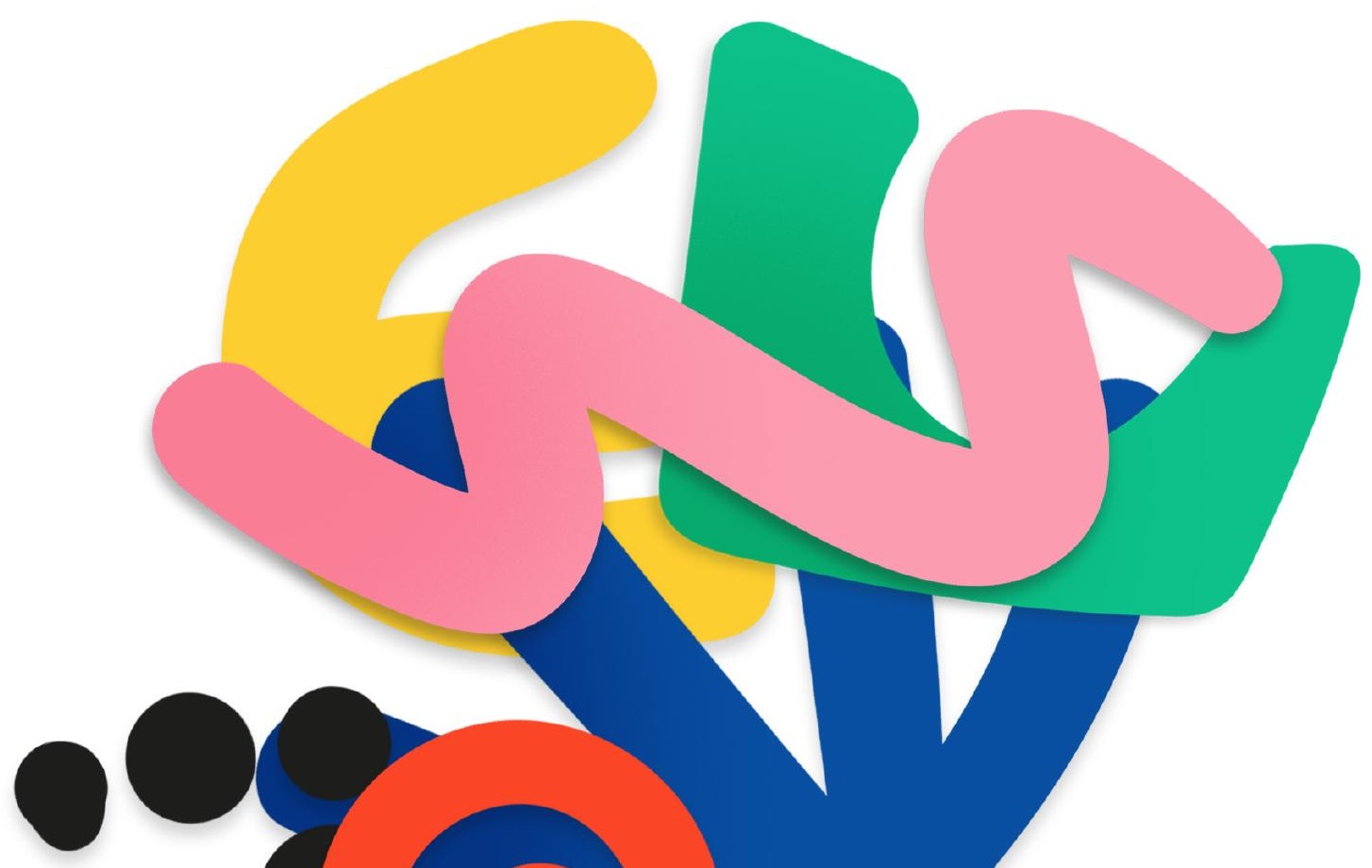




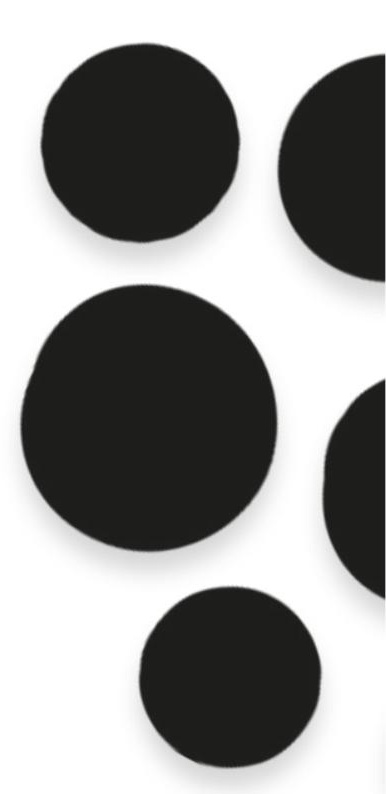




\title{
YOGA COM HISTÓRIAS \\ NA EDUCAÇÃO INFANTIL
}

\section{Vanessa Marinho Cunha Pescarollo Adriana Ortega Pereira Geralda Viana De Castro Coelho}

\author{
INTRODUÇÃO
}

Buscamos neste artigo discutir e aproximar a contação de histórias com a prática da yoga como base para movimento corporal da criança na Educação Infantil. Nesta fase educacional a mesma necessita de atividades que sejam lúdicas e que possam contribuir para seu desenvolvimento corporal, cognitivo e emocional, ou seja, o desenvolvimento integral da criança. Pensando na oportunidade de dar início a um estudo em que o corpo seja tratado a partir de uma concepção integral, na qual temos que ter em mente um ser humano com o corpo e intelecto saudáveis, iniciamos uma ação pedagógica que pudesse dar conta de alinhar a atividade corporal/movimento da yoga com a contação de história. A literatura infantil foi utilizada para ampliar o repertório das crianças e seu conhecimento de mundo e da diversidade cultural, mediando assim, o acesso da criança aos bens culturais da humanidade.

Esse trabalho da yoga na Educação Infantil surgiu a partir da parceria entre a Universidade Estadual 
Paulista UNESP/BAURU e a Secretaria Municipal de Educação de Bauru, por meio do programa de formação continuada de professores oferecida aos professores da Educação Infantil e séries iniciais do município, Costa (2015). Essa parceria teve o objetivo de construir uma formação pedagógica acerca dos conhecimentos da cultura corporal e dos movimentos da yoga, articulando à Proposta Pedagógica do Sistema Municipal de Ensino de Bauru à área de Cultura Corporal.

Nesse sentido, surgiu a necessidade de elaborar uma sequência de atividades que entrelaçassem a contação de história e a vivência da yoga na Educação Infantil. Foi promovida uma cuidadosa seleção de livros e materiais de pesquisa sobre a 272 yoga para a infância, essa prática foi desenvolvida numa escola de Educação Infantil pública do município de Bauru- SP com crianças de 3 a 4 anos.

Diante das considerações, buscamos realizaruma pesquisa bibliográfica que apontasse caminhos e oferecesse fundamentação teórica para o artigo e o trabalho realizado com as crianças. A pesquisa bibliográfica foi baseada nas concepções e ideias dos autores como: Arce (2010), Bettelheim (2002), Costa (2015), Flack e Coulon (2007), Gobbo \& Miller (2010), Machado (2004), Martins (2013), Rossi (2020), Vygotsky (1998,2001). Nesse artigo realizamos uma pesquisa bibliográfica sobre a importância da yoga para a infância, sua fundamentação e história intitulada Educação Infantil e yoga. Na 
segunda parte relacionamos a prática da contação de história e a seleção de conteúdo literário para a prática da yoga e, em seguida, apresentamos as vivências realizadas na escola de Educação Infantil.

\section{EduCação Infantil e Yoga}

A prática da yoga no contexto escolar não é recente, a pesquisa dos seus benefícios para as crianças vem sendo desenvolvida deste a década de 1970, os escritores Micheline e Jarques de Coulon (2007) foram pioneiros e desenvolveram uma metodologia voltada a prática de exercícios de respiração e relaxamento na sala de aula.

Utilizamos esse material Flak e Coulon (2007) como referencial da yoga na educação, pois traz a ideia de uma prática que integra corpo e mente da criança. Neste sentido, acreditamos que a yoga é uma prática que pode contribuir para muitos saberes na infância, visto que, ela surge na Índia como uma filosofia que busca integrar corpo, emoções e ações.

A Educação Infantil é um momento privilegiado de oportunidades de aprendizado para as crianças. Como primeira etapa da educação básica tem como função desenvolver todas as dimensões: físicas, emocional, afetivas, cognitiva, social e artística, bem como, propiciar para a criança a ampliação repertório cultural. Nesse contexto, as atividades corporais são excelentes, tendo em vista que, é através do movimento corporal que a criança explora e sente o mundo a sua volta. 
Diante disso, podemos enfatizar o papel fundamental da escola no desenvolvimento da criança e na ampliação de seu repertório cultural, lúdico e também, as possibilidades de alargar as atividades e práticas corporais, que normalmente são apresentadas nas escolas de Educação Infantil. Segundo destaca Gobbo (2010) sobre a importância da Educação Infantil de propiciar e potencializar o repertório cultural das crianças, que é nessa fase que deve haver a preocupação de ensinar a criança o que ela não sabe, ou seja, oferecer o acesso da criança aos bens culturais e toda a sua diversidade, pois muitas vezes, de outra forma a criança não terá oportunidade.

As Diretrizes Curriculares Nacionais da Educação 274 Infantil -DCNEI (BRASIL, 2009), em seu artigo $4^{\circ}$, define a criança como sujeito histórico e de direitos que, nas interações, relações e práticas cotidianas que vivencia, constrói sua identidade pessoal e coletiva, brinca, imagina, fantasia, deseja, aprende, observa, experimenta, narra, questiona e constrói sentidos sobre a natureza e a sociedade, produzindo cultura. A DCNEI, também define os eixos estruturantes das práticas pedagógicas na Educação Infantil, são eles: as interações e as brincadeiras, que se apresentam como experiências nas quais as crianças podem construir e se apropriar de conhecimentos, por meio de ações e interações com seus pares e com adultos, possibilitando assim, a aprendizagem, o desenvolvimento e a socialização. 
No Brasil o atendimento das crianças em creches e pré-escolas de Educação Infantil como um direito defendido desde a Constituição de 1998, reconhece a Educação Infantil como um dever do Estado e ela deve proporcionar o desenvolvimento integral da criança. Neste âmbito, se torna necessário o desenvolvimento das habilidades socioemocionais desde a mais tenra idade, já que o impacto positivo da Educação Infantil vai se estender até a vida adulta.

Em consonância com as Diretrizes Curriculares para a Educação Infantil (BRASIL, 2009) e a Base Nacional Comum Curricular, BNCC (BRASIL, 2017), documento normativo que tem por finalidade definir a política educacional a nível federal, destaca em seu texto o objetivo de oferecer na Educação Infantil uma educação integral, dando um importante passo no processo histórico de integração da Educação Infantil ao conjunto da educação básica. Este documento indica as aprendizagens essenciais a qual todas as pessoas devem ter acesso na educação básica. A BNCC (2017) propõe 6 Eixos estruturantes (conviver, brincar, explorar, participar, expressar e conhecerse) ou direitos de aprendizagem e desenvolvimento assegurando na Educação Infantil as condições para que as crianças aprendam em situações nas quais possam desempenhar um papel ativo, construindo significados sobre si, os outros, o mundo social e natural.

Geralmente a criança vai ter contato direto com a educação formal e a diversidade na escola 
de Educação Infantil (conhecendo outras crianças, professoras, funcionários), outro mundo que na maioria das vezes é bem diverso de sua própria família, desde o primeiro momento temos que promover oportunidades para trabalhar suas competências socioemocionais.

Desse modo, destacamos a relevância do trabalho com a prática da yoga e com a contação de histórias para desenvolver as habilidades socioemocionais de nossas crianças e também garantir o direito da criança ao aprendizado e ao seu desenvolvimento integral.

Contação de Histórias e Trabalho Pedagógico

Quando falamos da inserção de vivências da 276 Yoga na Educação Infantil, temos o pensamento voltado para a qualidade de vida e experiências de crianças e professores por proporcionar uma ampliação do nível de consciência através do autoconhecimento (Silveira, 2013). Flack \& Coulon (2007) defendem que os exercícios da Yoga despertam na criança a consciência de si mesma e, simultaneamente, a atenção no outro, o que permite o desenvolvimento do senso de responsabilidade em relação ao ambiente em que o outro está inserido. Segundo a pesquisadora da motricidade Fernanda Rossi, ressalta-se que:

Introduzir ayoga no contexto escolaréuma forma de propiciar às crianças a apropriaçãoe ampliação do repertório cultural das práticas 
corporais. Porém, mais do que "aprender a fazer" yoga, nosso intuito foi potencializar as experiências do se movimentar infantil (no sentido fenomenológico do movimento problematizado por Eleonor Kunz) com formas de expressão que as crianças ainda não haviam experimentado, com a intencionalidade dos gestos em detrimento de movimentos padronizados, isolados ou técnicos, visando descobertas e criações infantis, e fazer da yoga a arte do encontro com a motricidade. (ROSSI, 2000, p. 117).

Dessa forma, segundo Costa (2015), a Yoga pode ser útil como elemento na área da Cultura Corporal/Educação Física, proporcionado saúde e bem-estar por meio das posturas (asanas), técnicas respiratórias(pranayamas), que despertemaatenção e a concentração, mas também, proporcionem autocontrole da conduta além de momentos de aprendizagens e vivências de valores essenciais para a formação humana. Segundo Costa:

O reconhecimento da dimensão lúdica da infância integra o processo de ensino e aprendizagem deste conteúdo, a ser mediado por jogos e brincadeiras, contação de histórias, ao som de músicas diversas, imitação de animais etc. Trata-se de propiciar a vivência autêntica das manifestações corporais, contribuindo para que as crianças comecem a elaborar seus próprios significados relacionados à sua prática e à sua própria existência. (COSTA, 2015, p. 05) 
Para isso, a utilização da contação de história com a yoga precisa levar em conta as linguagens infantis nas suas múltiplas expressões, uma concepção de criança e infância que considere sua totalidade no seu contexto histórico, social e cultural colocando o movimento corporal como linguagem onde a criança percebe e se expressa, de acordo com Vygotsky (2001), a criança é um ser maximamente social, participante de um universo cultural material e simbólico desde seu primeiro momento de vida.

As histórias infantis fazem parte da infância e geralmente estão presentes desde o nascimento da criança, para fazer dormir ou entreter a criança elas foram e são uma fonte riquíssima de conhecimento simbólico e de potência imaginativa.

278 Elas ajudam a identificar e distinguir personagens bons e maus, devido à entonação e expressões faciais. Iniciando pelas imagens ela vai elaborando o conceito de leitura nas crianças. Nas palavras de Bamberger (1998) a criança entra em contato com a linguagem das gravuras (imagens) antes de aprender a ler ou entender o significado das letras. As gravuras ajudam a tornar o texto compreensível para os futuros leitores (Bamberger, 1998, p. 50). Quando Freire apresenta as palavras das histórias são como "grávidas de mundo", nos levando a pensar que "a leitura de mundo precede a leitura de palavra" (Freire, 1988, p. 20).

Percebendo este contexto a contação de histórias pode e deve ser utilizada como recurso 
pelo professor. Então a contação de histórias pode nos ajudar a elaborar melhor nossos conflitos internos por intermédio das aventuras e histórias, portanto, ressignificando emoções e sentimentos.

Vygotsky (1998) relata como uma arte e elemento significativo na construção do sujeito o contar de uma história. Segundo ele, a arte está na interação, quando a contação passa a agregar princípios das sensações, sentimentos e imaginação, sendo que “[...] todas as nossas vivências fantásticas e irreais transcorrem, no fundo, numa base emocional absolutamente real" (Vygotsky, 1998, p. 246).

A arte de contar história está ligada a uma antiga tradição de transmissão de conhecimento e é considerada como importante mediação cultural com a qual as crianças devem manter relação. Segundo Machado (2004) a escuta e a leitura de contos tradicionais podem nutrir, despertar, valorizar e exercitar o contato com imagens internas, abrindo possibilidades para que as questões das crianças e sua experiência pessoal de valores humanos fundamentais possam ser exercitados no contato com os contos e histórias tradicionais.

Tendo em vista, que a Educação Infantil é um momento privilegiado de sistematização do conhecimento, o professor é um agente mediador que articula os saberes e tem o papel de garantir a apropriação deste pelos seus alunos, a professora Alessandra Arce ressalta a importância das atividades lúdicas para as crianças. 
Para que as atividades lúdicas se coloquem a serviço da pratica pedagógica, é necessário um professor consciente de uma teoria que o oriente na articulação dos conteúdos trazidos pelos alunos com os conteúdos culturais e científicos e que reconheça no jogo, nos brinquedos e nas brincadeiras instrumentos culturais que desencadeiem o desenvolvimento e a aprendizagem, através da mediação do educador. (ARCE, 2010, p.186).

Destacamos o papel do professor como articulador do saber, que deve promover com intencionalidade momentos de atividade lúdica, que promova uma rotina de atividades 280 prazerosas, cheias de estimulação que possibilite o desenvolvimento cognitivo à criança.

A intencionalidade no trabalho do professor na Educação Infantil requer preparo, o professor precisa escolher o livro adequado aos seus objetivos, estar atento à faixa etária (seu público alvo). Alguns aspectos podem ser considerados na seleção do livro a ser lido como: assunto de interesse das crianças, descoberta de palavras novas, ritmo de palavras, frases e nomes, tempo e pausa, escolha adequada da obra para a faixa etária. É importante que o professor esteja familiarizado com a obra, ou seja, é preciso ler o livro ou a história antes para que possa transmitir as emoções e fazer adaptação, se necessário. 
Segundo Bettelheim o professor deve proporcionar assim, uma contextualização e consequentemente um maior envolvimento das crianças.

Para que a estória realmente prenda a atenção da criança, deve entretê-la e despertar sua curiosidade. Mas para enriquecer sua vida, deve estimular-lhe a imaginação: ajudá-la a desenvolver seu intelecto e a tornar claras as suas emoções; estar harmonizada com suas ansiedades e aspirações; reconhecer plenamente suas dificuldades e ao mesmo tempo sugerir soluções para os problemas que a perturbam (BETTELHEIM, 2002, p.13).

Assim, quando chegar a hora de narrar a história

o professor terá a capacidade de transmitir uma emoção e encantar as crianças.

Nesse sentido, procuramos sistematizar discussões, estratégias e possibilidades para que o professor utilize o recurso da contação de histórias e da prática da Yoga com a intenção de promover o desenvolvimento de nossas crianças.

Relato de UMA EXPERIÊNCIA Na EduCAÇÃo InfantIL.

Essa prática foi desenvolvida em uma escola da rede pública de Educação Infantil da cidade de Bauru com uma turma de 24 crianças de 3 a 4 anos. E contou com o apoio da gestão e da equipe escolar que compreendeu a importância do projeto e abraçou a ideia. 
Com o objetivo de contribuir para o desenvolvimento integral das crianças, os professores responsáveis pelas atividades fizeram uma observação das necessidades das crianças e elencaram os objetivos gerais e específicos a serem alcançados com a turma, atendendo ao estabelecido nos seis Direitos de Aprendizagem e DesenvolvimentonaEducação Infantilestabelecidos pela BNCC: conviver, brincar, participar, explorar, expressar e conhecer-se (BRASIL, 2017).

Para a realização do projeto empreendemos uma pesquisa bibliográfica para fundamentação da prática da yoga e uma investigação de histórias infantis a fim de atender aos objetivos das atividades. Para tanto, buscamos elaborar

282 o planejamento das etapas e sequências de atividades a serem realizadas. Importante destacar a necessidade de planejamento prévio para cada atividade e seleção de materiais como: livros, rádio, CDs e tapetes. Iniciamos uma vez por semana com as práticas e relacionando os movimentos da história com algum movimento corporal da yoga. As práticas tiveram o objetivo inicial de criar um momento prazeroso e lúdico, por meio de uma prática agradável às crianças. Para que, mesmo as crianças que apresentavam maiores dificuldades pudessem participar.

Descreveremos a seguir como a proposta foi desenvolvida, identificandoe analisando os resultados obtidos no desenvolvimento das atividades: 
- Iniciamos com o cumprimento Namastê (mãos juntas - palma da mão na altura do peito e dedos apontados para cima).

- Apresentação da Yoga as crianças - para isso foi realizada inicialmente uma roda de conversa (sentados em círculo) e de atividades lúdicas (brincadeiras) que oportunizassem às crianças a vivencia da yoga.

- Iniciamos com exercícios de respiração e alongamento como forma de aquecimento.

- Na contação de histórias utilizamos os exercícios para criar nas crianças um repertório das posturas e para que a criança se apropriasse dessas posturas. Finalizamos a aula com as crianças sentadas ou deitadas, em sentido de agradecimento, onde aproveitamos para fazer um momento de relaxamento.

Contação de História Desenvolvida:

História: Pinóquio

Objetivos: apresentação de novas posturas (montanha, árvore e bailarina)

Materiais: Bonecos, tapetes e rádio.

Local: Sala de aula

Tempo: 30 minutos

Descrição: a professora recebeu a turma de 24 alunos na sala de aula e se sentaram nos tapetes que já estavam em círculo, algumas crianças queriam brincar com os tapetes, então, deixamos que explorassem e iniciamos com uma 
conversa sobre a atividade do dia, a fim de criar uma expectativa nas crianças. Algumas crianças já sabiam que iria acontecer uma atividade diferente e ficaram atentas, outras nem tanto; normal nesta faixa etária, em a concentração é muito curta.

Utilizamos a estratégia de apresentar antes das práticas de apara a turma, uma história que fizesse a criança pequena prestar mais atenção na sequência de exercícios. A professora utilizou diversos objetos durante essa e outras atividades desenvolvidas para aproximar as crianças das histórias, como: Bonecos, fantoches, caixa de histórias, com o intuito de manter o foco das crianças na atividade desenvolvida.

Imagem 1 - Momento de aquecimento com alongamento.

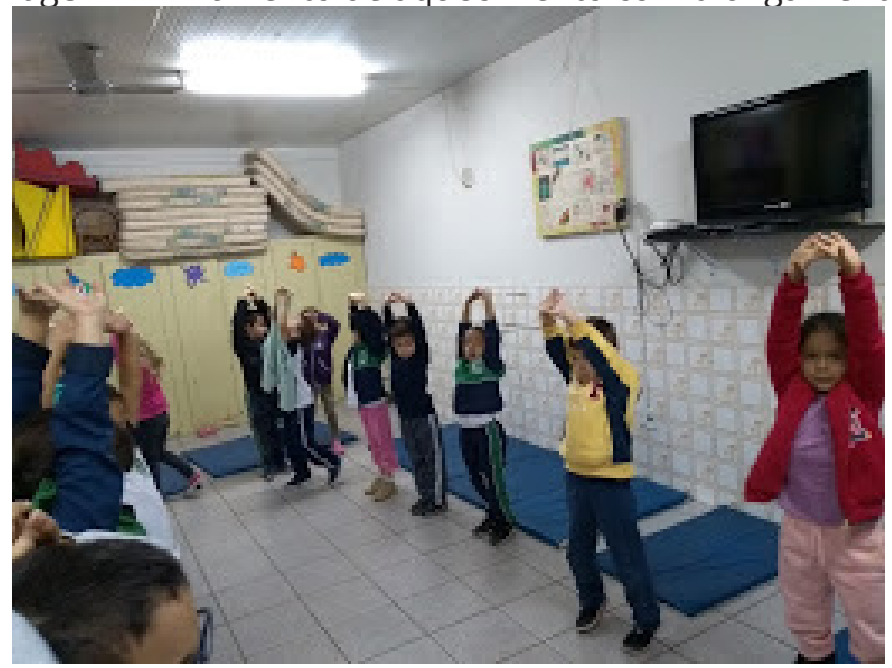

Fonte: arquivo da professora. 
Imagem 2 - Postura da tartaruga.

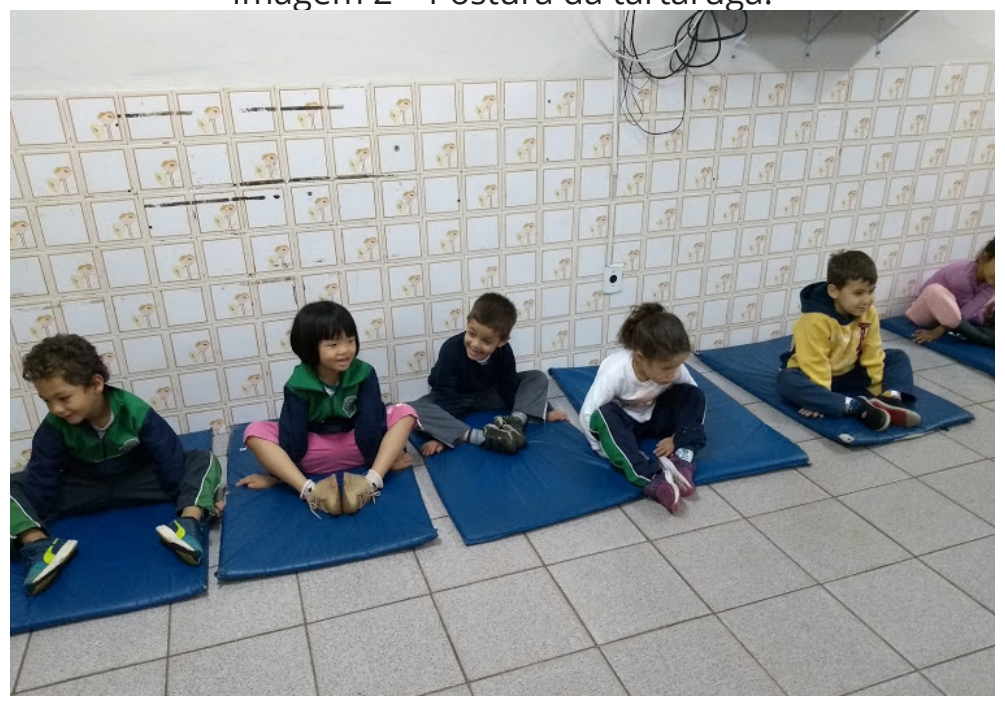

Fonte: arquivo da professora.

Imagem 3 - Representação do esquema corporal.

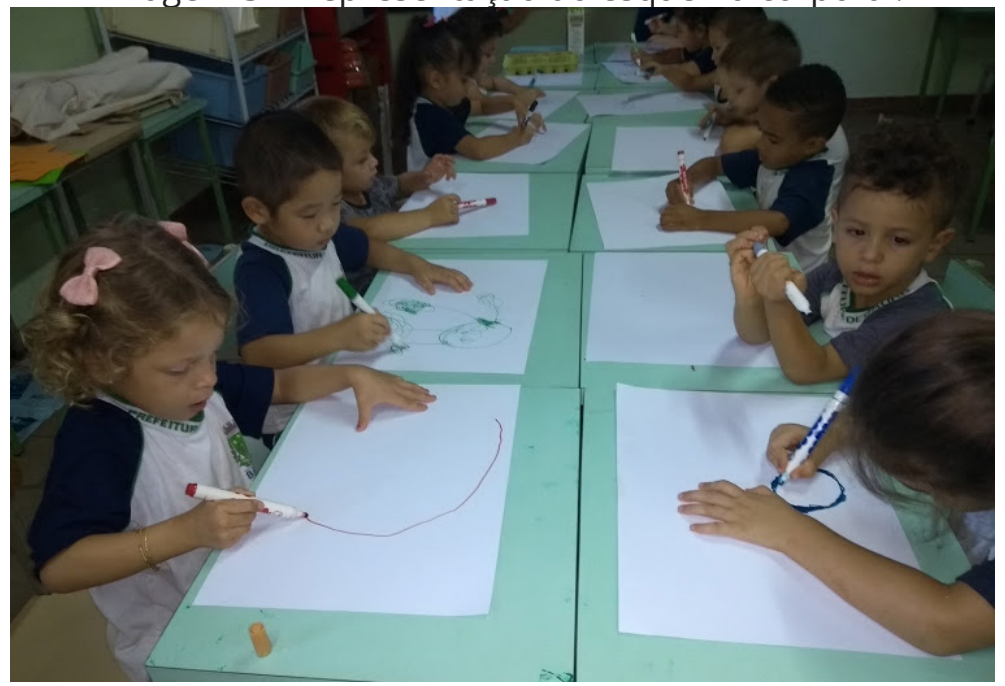

Fonte: arquivo da professora.

Yoga com HistóRIAS na Educação Infantil 
Imagem 4 - Desenho da história do Pinóquio.

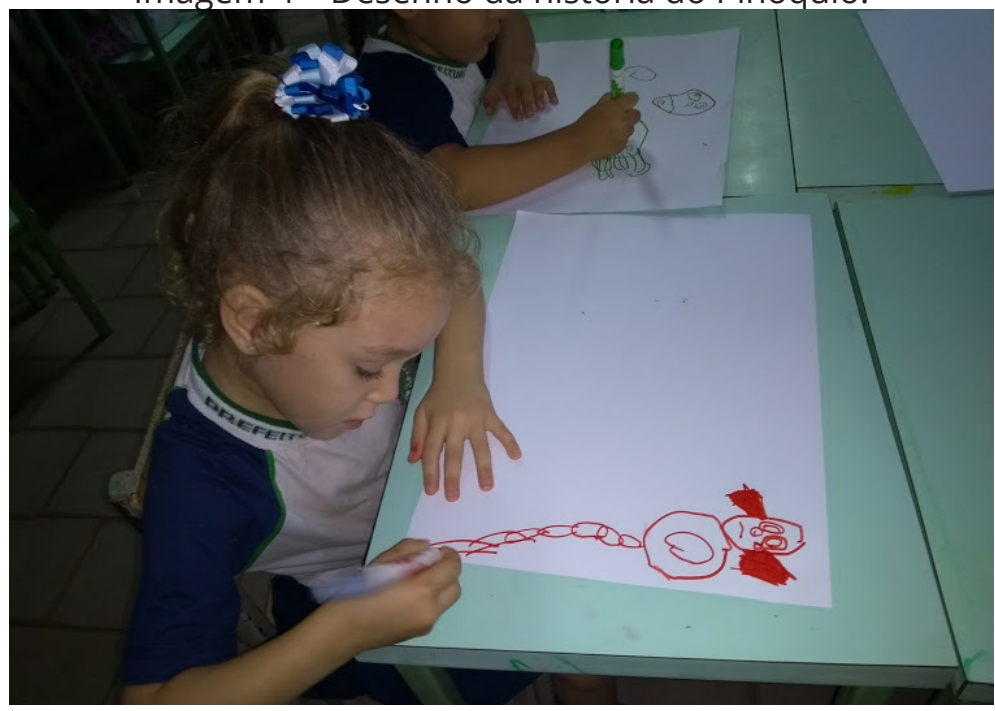

Fonte: arquivo da professora.

Imagem 5 - Prática de Yoga no pátio da escola.

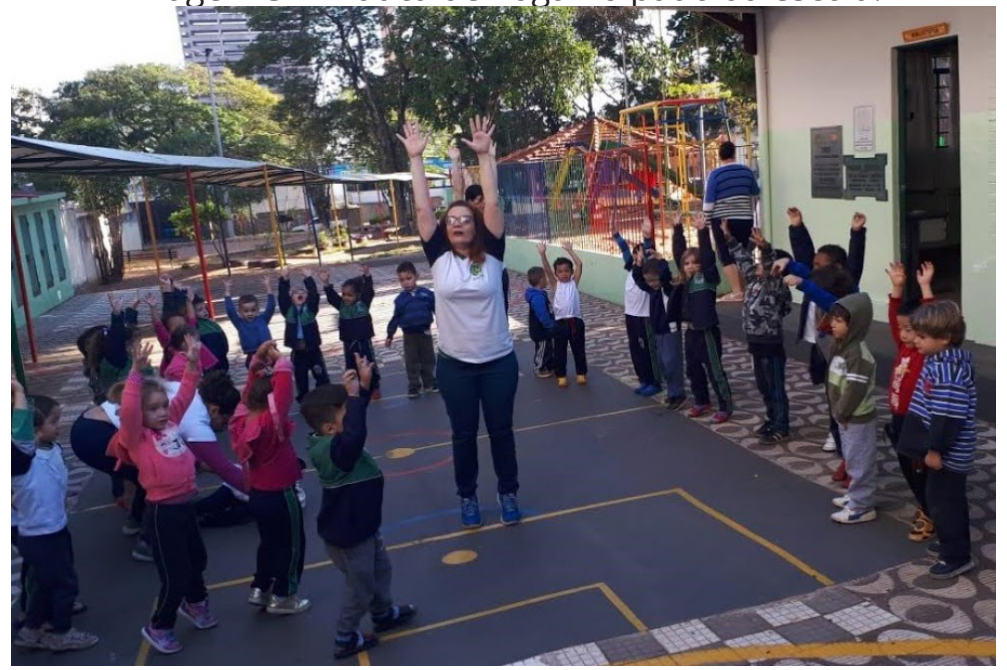

Fonte: arquivo da professora. 


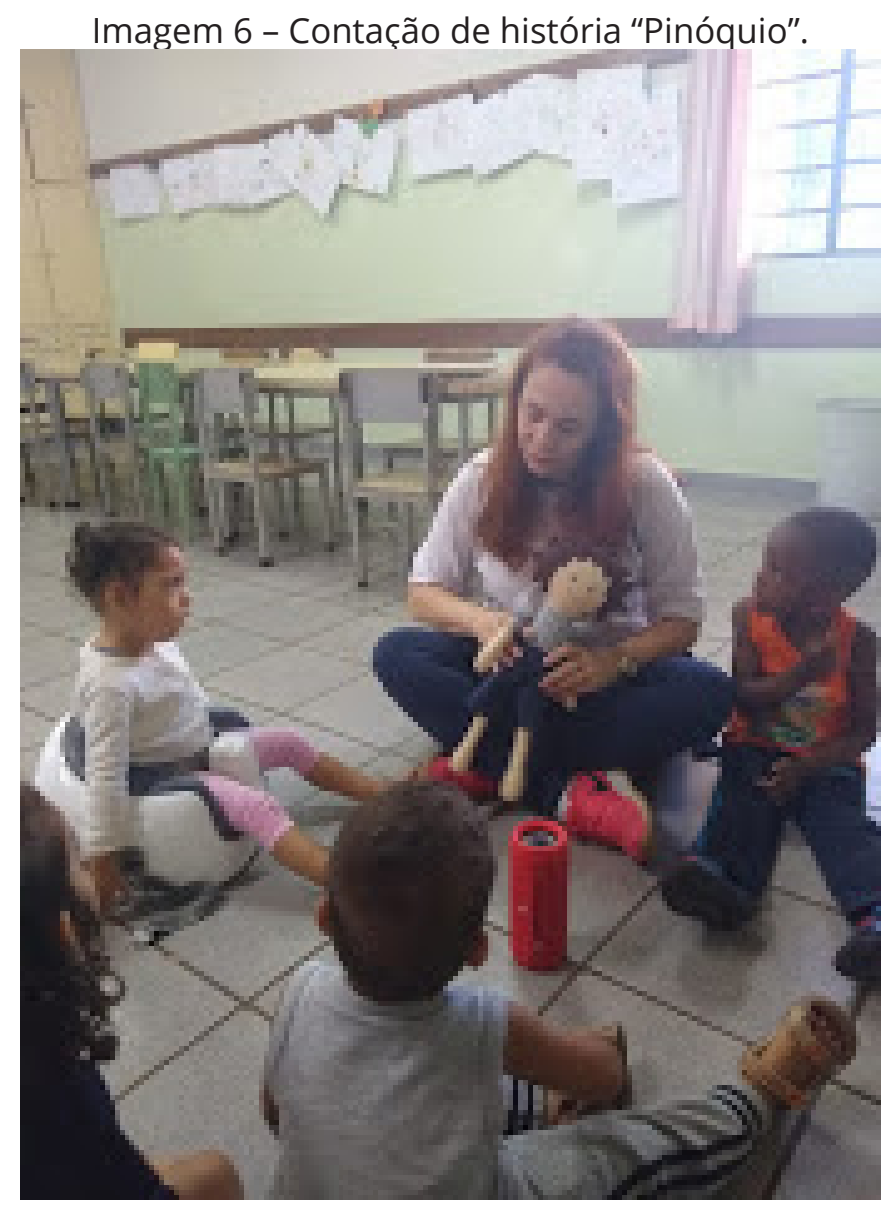

Fonte: arquivo da professora.

Avaliação: as crianças se mostraram sempre receptivas no decorrer das atividades, um fato relevante, e que, quando alguma criança apresentava alguma dificuldade ou desinteresse, a professora sempre tinha uma palavra de incentivo 
para estimular e alegrar as crianças. Ademais, não é um trabalho fácil organizar atividades para crianças tão pequenas. Por isso, durante as atividades sempre eram realizadas com duas professoras e uma auxiliar de educação. Foi observado durante esse processo o desenvolvimento de outras habilidades de aprendizagem como a linguagem oral e escrita que está diretamente ligada ao projeto.

A seleção das histórias atendeu aos objetivos de despertar valores como empatia, solidariedade, amizade, amor, aceitação e autoestima. Martins (2013) alerta para a importância da seleção do conteúdo partindo dos clássicos, mas sempre em dialética com o que norteia os objetivos a serem atingidos. Para Sacristán \& Goméz (2000, 288 p. 14), a escola tem como dever desenvolver "não só, nem principalmente, conhecimentos, ideias, habilidades e capacidades formais, mas também, de disposições, atitudes, interesses e pautas de comportamento". E com o conhecimento do que precisamos ensinar e de como devemos fazêlo, podemos eleger estratégias coerentes que alicerçam as práticas docentes.

\section{ConCLUSÃo}

O processo avaliativo aconteceu durante todo o desenvolvimento do projeto, com isso, no decorrer do ano foi possível observar o entusiasmo das crianças na hora da contação de histórias e a alegria delas em serem desafiadas com as brincadeiras corporais. 
Como método avaliativo deste projeto de contação de histórias, levamos em conta os princípios éticos da yoga e a observação das aprendizagens durante o processo de ensino e aprendizagem

Foi possível verificar a receptividade das crianças com relação à prática da yoga e as histórias contadas na sala de aula. Para tanto, com as rodas de conversa ao final de cada encontro, sondagem em relação à eficiência da implantação da yoga no ambiente escolar com caráter inclusivo, observouse os princípios de apreensão das posturas corporais, respiração e a associação das posturas com seus nomes. As crianças tiveram grande interesse nas atividades desenvolvidas com a yoga e uma maior autonomia corporal e destreza nos movimentos e autoconfiança. Sabemos que a prática da yoga é muito mais complexa e que o projeto apresentado não dá conta de sua totalidade, entretanto, é uma forma de apresentar para as crianças e a comunidade escolar que é possível fazer atividades inovadoras que desafiem as crianças. Possibilitando ainda, outras experiências e possibilidades de aprendizagem, bem como, o acesso aos bens culturais e conhecimento historicamente construídos pelo homem.

Também foi possível observar o interesse dos professores pelas atividades corporais não convencionais. Logo, é possível considerar a yoga na contação de histórias como um recurso aliado ao desenvolvimento pleno de nossas crianças. As histórias selecionadas possibilitaram 
o desenvolvimento cognitivo e emocional e despertaram o interesse e o encantamento das crianças pequenas pelas narrativas orais que são uma rica tradição da humanidade.

Assim, destacamos o papel fundamental do professor como aquele que possibilita o acesso ao conhecimento historicamente acumulado pelo homem. Sugerimos que o professor tenha um mínimo de conhecimento prévio básico de Yoga para conseguir fazer as necessárias adaptações entre as histórias e as vivências.

Portanto, concluímos que a Educação Infantil tem um impacto positivo na vida das crianças que se estende até a sua vida adulta. Dessa forma, a educação escolar possui papel fundamental 290 no desenvolvimento da criança, tanto nas suas relações interpessoais, quanto nas suas relações intrapessoais. Recomendamos que a Yoga juntamente com o recurso da contação de histórias seja mais explorado no cotidiano escolar, já que, eles podem proporcionar o desenvolvimento integral de nossas crianças, tornando-as seres humanos mais sensíveis e atentos às necessidades do autocuidado, cuidado com o próximo e com o mundo que os cerca.

\section{REFERÊNCIAS}

ARCE, Alessandra Martins, Lígia Marcia. (orgs). Quem tem medo de ensinar na educação infantil? Em defesa do ato de ensinar. Ed. Alínea. São Paulo. 2010. 
BAMBERGER, Richard. Como incentivar o hábito de leitura. São Paulo: Ática, 1988.

BETTELHEIM, Bruno. A psicanálise dos contos de fadas. Tradução de Octávio Mendes Cajado.

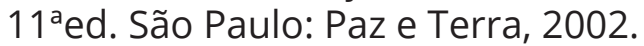

BRASIL, Ministério da Educação. Base Nacional Comum Curricular. 2017. http://basenacionalcomum. mec.gov.br/images/BNCC_El_EF_110518_versaofinal_ site.pdf $>$. Acesso em: 25 Nov. 2020, 15:10.

BRASIL. Ministério da Educação. Diretrizes curriculares nacionais para a educação infantil. Brasília: MEC/SEB, 2010.

CASTILHO, M. C.; BOMFIM, E. A. Rata Yoga: uma introdução ao Hatha Yoga para crianças. São Paulo: Evoluir, 2006.

COSTA, Cristina da Silva Vital et al. Educação Infantil e Yoga: primeiras experiências para construção coletiva de material didático-pedagógico. UNESP/Bauru. 2015.

Disponível em: <https://www.marilia.unesp.br/Home/ Eventos/2015/jornadadonucleo/educacao-infantil-eyoga.pdf $>$. Acesso em: 12 dez. 2020, 14:14.

FLAK, Micheline; COULON, Jaques de. Yoga na Educação: Integrando corpo e mente na sala de aula. Florianópolis: Comunidade do saber, 2007.

FREIRE, Paulo. Educação e mudança. São Paulo: Paz e Terra, 1988.

GOBBO, Gislaine Rossler Rodrigues; MILLER, Stela. A imaginação infantil: relações entre gêneros discursivos, desenhos e brincadeiras de papéis sociais. São Carlos: Pedro \& João Editores, 2019.

MACHADO, Regina. Acordais - Fundamentos teóricos e poéticos da arte de contar histórias. Editora Difusão Cultural do livro. São Paulo. 2004.

ROSSI, Fernanda. Corporeidade e yoga na educação infantil: experiências e descobertas. Rev. 
SPQMH. v. 4, n.2, p.113-126, maio-ago. 2020 ISSN 25946463 DOI: http://dx.doi.org/10.29181/2594-6463.2020. v4.n.113-126 Corporeidade e yoga na educação infantil: experiências e descobertas.

SACRISTÁN, José Gimeno \& GÓMEZ, Pérez Angel. As funções sociais da escola: da reprodução à reconstrução crítica do conhecimento e da experiência. Compreender e transformar o ensino. Porto Alegre: ARTMED, 2000.

SILVEIRA, Maria Claurência Abreu de Andrade. Yoga para crianças - uma prática em construção. Revista Religare, v. 9, n. 2, p. 177-185, 2013.

VYGOTSKY, Liev Semianovich. A construção do pensamento e da linguagem. São Paulo. Martins Fontes. 2001. Artmed, 1998.

Psicologia da Arte. Porto Alegre: 


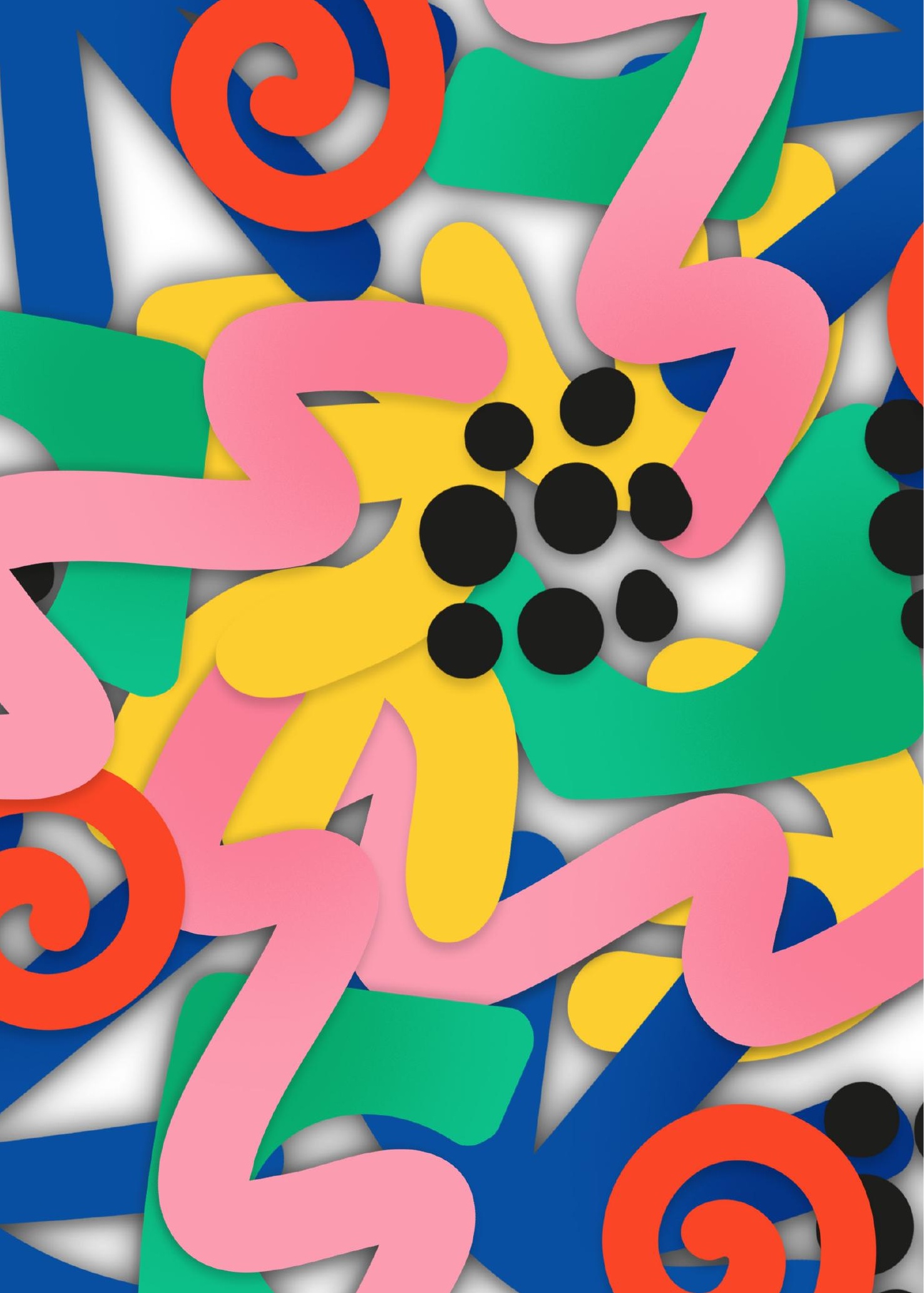




\section{SOBRE OS AUTORES}

\section{AS ORGANIZADORAS}

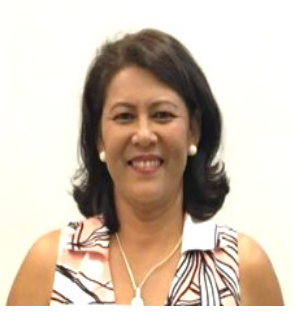

Sintia Otuka Rossi é mestre pelo Programa de Pós-graduação em Docência para a Educação Básica pela Faculdade de Ciências de Bauru da Universidade Estadual Paulista Júlio de Mesquita Filho - UNESP. Possui graduação em Pedagogia pelo Centro Universitário Internacional de Curitiba. Licenciada em Matemática pela Faculdade "Auxílium" de Filosofia e Letras e Bacharelado em Ciências Econômicas pela Instituição Toledo de Ensino, Faculdade de Ciências Econômicas de Bauru. É membro do Grupo de Pesquisa Infância e Educação Infantil: Políticas e Programas (GEI-UNESP). É professora de Educação Básica Infantil no Sistema Municipal de Ensino de Bauru.

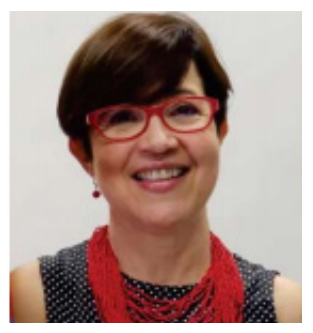

Maria do Carmo Monteiro
Kobayashi é professora
Associada - Livre Docente em
Ensino de Arte: Linguagens da
Criança, pela Universidade 
Estadual Paulista Júlio de Mesquita Filho Unesp, Faculdade de Ciências de Bauru. Mestre e Doutra em Educação Brasileira - UNESP de Marília. Especialista em Linguagens da Arte, pelo Centro Universitário Maria Antônia - USP. Pedagoga licenciada pela Universidade do Sagrado Coração. Realiza estudos na área da formação inicial e continuada de professores de Educação Básica. Atua, principalmente, nas Linguagens da Arte e Educação na educação Infantil; Ensino Fundamental; Ensino e aprendizagem; Ludicidade e Arte; Cultura lúdica dos imigrantes japoneses. Com aprofundamento no campo da Arte e objetos lúdicos: jogos, brinquedos, literatura infantil e arte nos anos iniciais da educação 296 Básica. Membro do International Toy Research Association - ITRA. Docente do Programa de Pósgraduação em "Docência para a Educação Básica" - Mestrado Profissional, Faculdade de Ciências da UNESP/Bauru. Líder do Grupo de Estudos da Infância e Educação Infantil: Políticas e Programas CNPQ-UNESP. Conselheira da Associação de Brinquedotecas 2018-2020.

\section{OS AUTORES}

Adriana Ortega Pereira

Pós graduação em Lato- sensu Habilitação psicopedagógico para professores e profissionais afins para o Ensino Especializado na área de 
Deficiência mental e múltiplas na Educação Inclusiva.Instituto de Ensino Superior de Garça. Graduação: -Pedagogia com Habilitação para em deficiência auditiva pela UNESP- Júlio Mesquita. -Licenciatura em Artes Visuais pela Universidade Metropolitana de Santos. Lattes: http://lattes.cnpq. br/5367473917638432.

Alessandra Salvador Costa Morijo Pós graduada em Alfabetização e Letramento pelo Centro Universitário Internacional -UNINTER. Possui Licenciatura em Pedagogia pelo Centro Universitário Internacional-UNINTER Currículo Lattes: http://lattes.cnpq.br/0962441100047648 Orcid: https://orcid.org/0000-0002-6488-8171 E-mail: alessandracosta_14@ hotmail.com

\section{Alice Nicassio de Oliveira}

Especialista em Educação a Distância pelo Serviço Nacional de Aprendizagem Comercial, SENAC - Rio deJaneiro/RJ. Graduada em Pedagogia pelo Instituto de Ensino Superior de Bauru, IESB - Preve, Bauru/ SP. Email: alicenicassio@yahoo.com.br Currículo Lattes: http://lattes.cnpq.br/9393760616024035 . Orcid: https://orcid.org/0000-0002-1561-1758

Ana Claudia da Silva Pereira

Especialista em Gestão Escolar - Diretora de Escola de Educação Infantil no Sistema Municipal de Ensino de Bauru-SP. Graduada em Psicologia 
pela Universidade do Sagrado Coração e Pedagogia pela Universidade Nove de Julho. Mestra em Docência para a Educação Básica pela UNESP Bauru. Membro do Grupo de Pesquisa Infância e Educação Infantil: Políticas e Programas (GElUNESP). E-mail: anaclaudia@bauru.sp.gov.br

Bruna Di Richelle Souza Padovini Mestre em Educação pela Universidade Estadual Paulista "Júlio de Mesquita Filho" - UNESP - BauruSP. Especialista em Alfabetização e Letramento pelo Centro Universitário Internacional, Graduada em Pedagogia com Complementação em Gestão Escolar pela Universidade Estadual Paulista "Júlio de Mesquita Filho" - UNESP - Bauru -SP. E-mail:

298 brunarichelly@gmail.com.

\section{Carita Pelição}

Licenciada em Artes Visuais pela Universidade Estadual Paulista "Júlio de Mesquita Filho" (UNESP), campus de Bauru/SP; Pedagogia pela Universidade Nove de Julho (UNINOVE) de Bauru/ SP. Possui Pós-Graduação Lato Sensu em Docência para a Educação Básica pelo Instituo Federal de Minas Gerais - IFMG e Pós-Graduação em Alfabetização e Letramento pela Acrópole, Bauru/ SP. É aluna regular de mestrado no Programa de Pós-Graduação em Desenvolvimento Humano e Tecnologias da UNESP/Rio Claro, sendo bolsista do Programa de Coordenação de Aperfeiçoamento de Pessoal de Nível Superior (CAPES). Lattes: http:// 
lattes.cnpq.br/5394414238425817; ORCID: https:// orcid.org/0000-0003-4800-4804; E-mail: carita. pelicao@unesp.br.

Fabiana Hortolani Sartori

Pós graduada em Alfabetização e Letramento pelo Centro Universitário Internacional UNINTER. Pós graduada em Educação Infantil e Educação Musical pela Faculdade Única. Possui Licenciatura em Pedagogia pelo Centro Universitário Internacioanal-UNINTER - Lattes: http://lattes.cnpq.br/9398360277954846 - Orcid: https://orcid.org/0000-0003-0513-2443 - E-mail: fabianahortolanisartori@gmail.com

Fernanda Rossi

Professora Assistente Doutora do Departamento de Educação da Faculdade de Ciências da UNESP Bauru. Graduada em Licenciatura em Educação Física pela UNESP Bauru e mestra e doutora em Ciências da Motricidade pela UNESP Rio Claro. Vicelíder do Grupo de Estudos e Pesquisas Históricas, Sociológicas e Pedagógicas em Educação Física. E-mail: fernanda.rossi@unesp.br

\section{Geralda Viana De Castro Coelho}

Pós graduação em Educação Especial - Ensino especializado de alunos com necessidades educacionais especiais inclusiva. Pela Faculdade José Bonifácio. Pós graduação em Psicopedagogia e Educação Infantil pela Universidade Cândido 
Mendes. Possui licenciatura em Pedagogia pela USC- Universidade do Sagrado Coração.Email: geraldavianacastro@gmail.com Currículo Lattes: http: lattes.cnpq.br/1701973184531655

Janaina Fernanda Gasparoto Fusco

Mestre pelo Programa de Pós Graduação em Docência para a Educação Básica da Faculdade de Ciências da UNESP Bauru(2017); graduação em Psicopedagogia - UNICAMPROMINAS (2013) e graduação em Pedagogia pela Universidade do sagrado coração (2008). http://lattes.cnpq. br/6995281735548116. Email: janaina.fusco@ educa.bauru.sp.gov.br. Orcid 0000.0003.3846.1681

Josilaine Aparecida Pianoschi Malmonge Mestre em Educação pela Universidade Estadual Paulista "Júlio, de Mesquita Filho" (UNESP), campus de Bauru/SP. Graduada em Pedagogia pela Universidade Nove de Julho, em Matemática pela Universidade Metropolitana de Santos e em Ciências Biológicas pela Universidade do Sagrado Coração (USC), Bauru/SP. Currículo Lattes: http://lattes.cnpq.br/5026388473147181 . Orcid: https://orcid.org/0000-0002-9219-2753 . E-mail: jmalmonge@gmail.com.

Keila Cristina Armando de Moraes

Graduada em Pedagogia (2002), Pós-Graduação em Psicopedagogia (2004) pela Universidade do Sagrado Coração; Especialização em Gestão 
Escolar pela Universidade Candido Mendes, Brasil (2017); Mestranda em Educação Profissional pela Universidade Federal de São Carlos (UFSCar) 2021 http://lattes.cnpq.br/4330867760493352. Email: keila.moraes@educa.bauru.sp.gov.br. Orcid 0000.0002.8998.6755

Lígia Maria Ramazzini Remaeh

Doutora e Mestre em Ciências Biológicas pelo Instituto de Biociências da UNESP de Botucatu, Pós-graduada em Educação Infantil pela Faculdade Paulista e em Neuropsicopedagogia pela Universidade Cândido Mendes, Pedagoga pela Universidade Nove de Julho e graduada em Ciências Biológicas pela UNESP/Bauru - Currículo Lattes: http://lattes.cnpq.br/8826894323546705

- OrCid: https://orcid.org/0000-0002-2208-1986 E-mai: ligia.remaeh@educa.bauru.sp.gov.br

Simone Aparecida Ferreira Xavier Tuler Mestranda em Educação pela Universidade Estadual Paulista "Júlio de Mesquita Filho" - UNESP - BAURU - SP. Especialista em Educação Infantil e Anos Iniciais pela Faculdade Venda do Imigrante FAVENI, Graduada em Pedagogia pela Universidade Estadual Paulista "Júlio de Mesquita Filho" - UNESP BAURU - SP. E-mail: simoninhaferreira@gmail.com

Taís Pelição

Aluna regular de mestrado no Programa de Pós Graduação em Desenvolvimento Humano 
e Tecnologias do Instituto de Biociências da Universidade Estadual Paulista "Júlio de Mesquita Filho" (UNESP), campus de Rio Claro/SP, sendo bolsista do Programa de Coordenação de Aperfeiçoamento de Pessoal de Nível Superior (CAPES); Licenciada em Educação Física pela Faculdade de Ciências (FC) da UNESP de Bauru/SP; aluna de Bacharelado em Educação Física também pela UNESP de Bauru/ SP. Lattes: http://lattes. cnpq.br/3133314862697758; ORCID: https://orcid. org/0000-0003-0106-149X; E-mail: tais.pelicao@ unesp.br. 